\title{
PROBLEM ZARACHOWANIA W NORMATYWIZMIE HANSA KELSENA
}




\section{JURYSPRUDENCJA $1 / 2014$}


盛 


\section{JURYSPRUDENCJA \\ $1 / 2014$}

Monika Zalewska

PROBLEM ZARACHOWANIA W NORMATYWIZMIE HANSA KELSENA 


\title{
REDAKTORZY
}

Marek Zirk-Sadowski (Uniwersytet Łódzki), Tomasz Bekrycht (Uniwersytet Łódzki)

\author{
SEKRETARZ \\ Rafał Jerzy Kruszyński (Uniwersytet Łódzki)
}

RADA PROGRAMOWA

Andrzej Bator (Uniwersytet Wrocławski), Tadeusz Biernat (Krakowska Akademia im. A.F. Modrzewskiego), Stanisław Czepita (Uniwersytet Szczeciński), Tomasz Gizbert-Studnicki (Uniwersytet Jagielloński), Mariusz Golecki (Uniwersytet Łódzki), Małgorzata Król (Uniwersytet Łódzki), Grzegorz Leszczyński (Uniwersytet Łódzki), Jerzy Leszczyński (Uniwersytet Łódzki), Leszek Leszczyński (Uniwersytet Marii Curie-Skłodowskiej w Lublinie), Lech Morawski (Uniwersytet Mikołaja Kopernika w Toruniu), Tomasz Pietrzykowski (Uniwersytet Śląski), Marek Smolak (Uniwersytet im. Adama Mickiewicza w Poznaniu), Tomasz Stawecki (Uniwersytet Warszawski), Bartosz Wojciechowski (Uniwersytet Łódzki), Sylwia Wojtczak (Uniwersytet Łódzki), Jerzy Zajadło (Uniwersytet Gdański), Wojciech Załuski (Uniwersytet Jagielloński)

\author{
RECENZENT \\ Jerzy Stelmach \\ Monika Zalewska - Uniwersytet Łódzki, Wydział Prawa i Administracji \\ Katedra Teorii i Filozofii Prawa, Zakład Teorii i Filozofii Prawa \\ 90-232 Łódź, ul. Kopcińskiego 8/12 \\ REDAKTOR WYDAWNICTWA UŁ \\ Ewa Siwińska \\ SKŁAD I ŁAMANIE \\ $A G E N T$ PR \\ OKŁADKĘ PROJEKTOWAEA \\ Barbara Grzejszczak
}

Niniejsza publikacja jest dofinansowana w ramach dotacji na zadania służące rozwojowi młodych naukowców i doktorantów

(C) Copyright by Uniwersytet Łódzki, Łódź 2014

Wydane przez Wydawnictwo Uniwersytetu Lódzkiego

Wydanie I. W.06314.13.0.K

ISBN 978-83-7525-999-5

https://doi.org/10.18778/7525-999-5

Wydawnictwo Uniwersytetu Lódzkiego

90-131 Łódź, ul. Lindleya 8

www.wydawnictwo.uni.lodz.pl

e-mail: ksiegarnia@uni.lodz.pl

tel. (42) 6655863 , faks (42) 6655862 


\section{Spis treści}

Spis skrótów

Wstęp

Rozdział I. Normatywizm i jego ewolucja

1.1. Ogólne pojęcie normatywizmu

1.1.1. Teza o rozdziale i krytyka tezy o związku

1.1.2. Teza normatywna i krytyka tezy redukcyjnej

1.2. Problem periodyzacji

Rozdział II. Podstawowe pojęcia normatywizmu i podstawy metodologiczne 37

2.1. Ogólny zarys podstawowych pojęć normatywizmu

2.1.1. Pojęcie normy prawnej

2.1.2. System prawa i jego obowiązywanie

2.1.3. Norma podstawowa

2.2. Podstawy metodologiczne

2.2.1. Pozytywizm prawniczy i metoda formalno-dogmatyczna

2.2.2. Metoda normatywna

2.2.3. Dualizm bytu i powinności

Rozdział III. Ogólne pojęcie zarachowania i jego typy

3.1 Zarys historyczny ewolucji pojęcia zarachowania

3.1.1 Samuel Pufendorf

3.1.2 Immanuel Kant

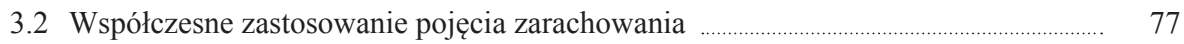

3.3. Zarachowanie, a przyczynowość - uwagi ogólne _..................................................... 81

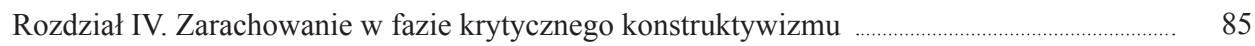

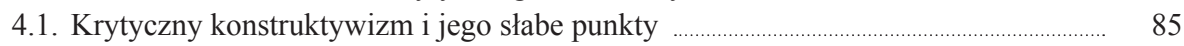

4.2. Dualizm bytu i powinności

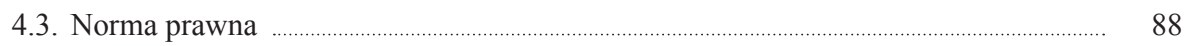

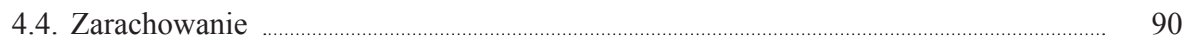

4.4.1. Zarachowanie na obowiązek i zarachowanie na prawo ............................. 90

4.4.2. Zarachowanie centralne jako operator powinnościowy …………...................... 91

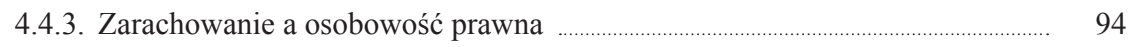

4.4.4. Zarachowanie a celowość i przyczynowość _......................................... 100

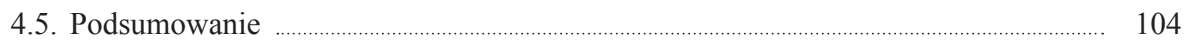




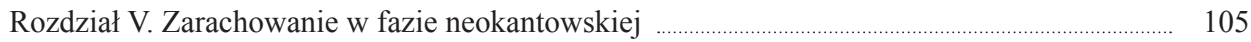

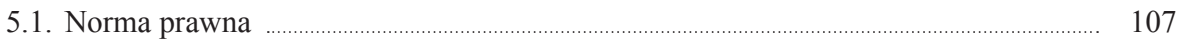

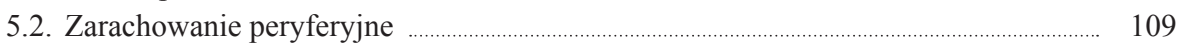

5.2.1. Zarachowanie jako operator powinnościowy _...................................... 110

5.2.2. Zarachowanie $\mathrm{i}$ argument transcendentalny _.......................................... 117

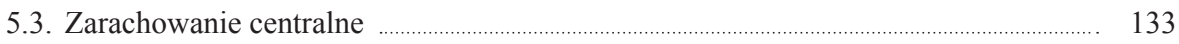

5.4. Relacje zachodzące między zarachowaniem centralnym a peryferyjnym .................... 137

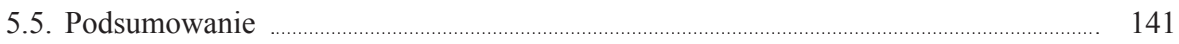

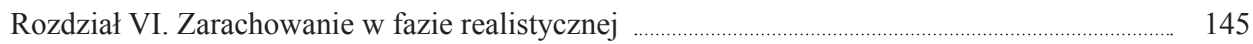

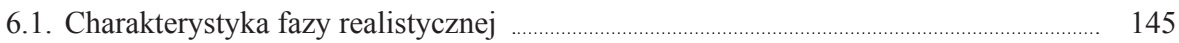

6.2. Dualizm bytu i powinności ….................................................................................... 148

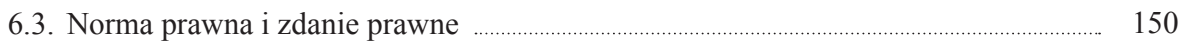

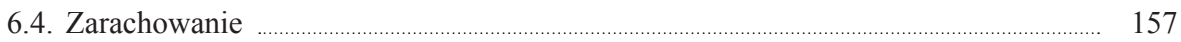

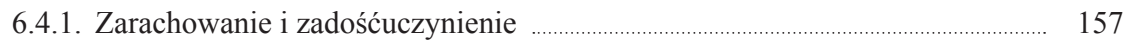

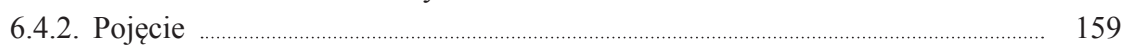

6.4.3. Zarachowanie a zdanie prawne _..................................................................... 164

6.4.4. Zarachowanie jako relatywna kategoria a priori? ….............................................. 167

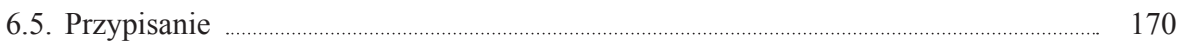

6.6. Zarachowanie a przypisanie …….......................................................................................... $\quad 175$

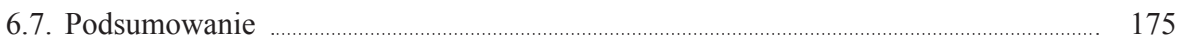

Rozdział VII. Zarachowanie w fazie językowo-analitycznej _................................................................. 177

7.1. Charakterystyka fazy językowo-analitycznej ................................................................. 177

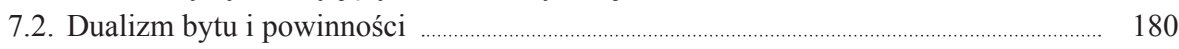

7.2.1. Dualizm bytu i powinności na płaszczyźnie językowej …..................................... 180

7.2.2. Funkcje powinności i jej podziały ….............................................................. 182

7.3. Norma prawna

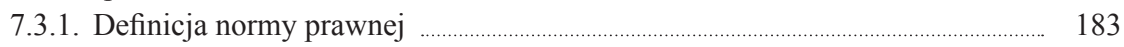

7.3.2. Podziały norm prawnych …............................................................................................ 186

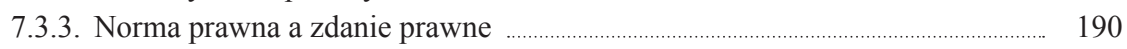

7.3.4. Normy i logika …................................................................................................... 193

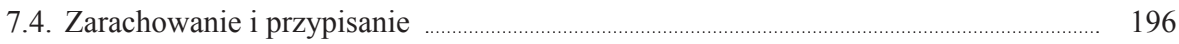

7.4.1. Definicja i charakter zarachowania …….......................................................... 196

7.4.2. Zarachowanie a norma prawna …................................................................................. 200

7.4.3. Zarachowanie a podmiot prawa ………................................................................... 202

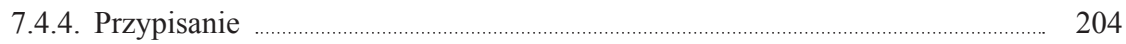

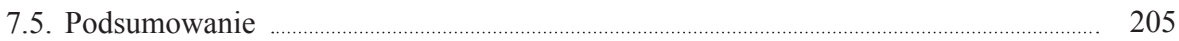

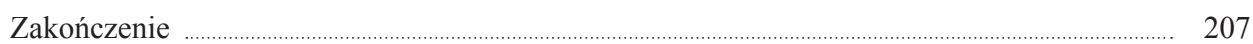

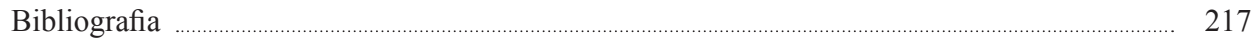




\section{Wykaz skrótów}

ASL - H. Kelsen, Allgemeine Staatslehre, Österreichische Staatsdrückerei, Wien, Nachdrück 1993

ATN - H. Kelsen, Allgemeine Theorie der Normen, Manzsche Verlags- und Universitätsbuchhandlung, Wien 1979

GTLS - H. Kelsen, General Theory of Law and State, The Law Book Exchange Ltd. Union, New Jersey 1999

HP I - Hauptprobleme der Staatsrechtslehre [H. Kelsen, Podstawowe zagadnienia nauki prawa państwowego (w rozwinięciu nauki o normie prawnej), thum. T. Przeorski, Wilno 1935-1936]

HP II - H. Kelsen, Hauptprobleme der Staatsrechtslehre, Scientia Aalen, 1960

RR1 - H. Kelsen, Reine Rechtslehre, 1934, przedruk: Mohr Siebeck, Tübingen 2008

RR2 - H. Kelsen, Reine Rechtslehre, Verlag Franz Deuticke, Wien 1960 



\section{Wstęp}

Publikacje Jerzego Wróblewskiego i Kazimierza Opałka sprawiły, że teoria Hansa Kelsena wywarła ogromny wpływ na obecną kulturę prawną w Polsce. O Kelsenie słyszał nieomal każdy prawnik w Polsce, a jego wizja prawa widoczna jest nawet $\mathrm{w}$ sędziowskich uzasadnieniach ${ }^{1}$. Wpływ Kelsena na polską kulturę prawną jest duży, jednak w odmianie, którą Marek Zirk-Sadowski nazywa „soft-kelsenizmem". Polega on na adaptacji założeń normatywizmu przy jednoczesnym pominięciu wątków neokantowskich i transcendentalnych ${ }^{2}$. Owa powszechna znajomość założeń normatywizmu w środowisku prawniczym jest dowodem triumfu kelsenowskiej teorii, jednak niesie ze sobą również niebezpieczeństwo, z którym musi się zmagać każda „oczywistość”. To, co oczywiste, przestaje być dostrzegane, zanika i staje się pustym pojęciem, nie posiadającym w sobie prawie żadnej treści. Jest słowem kluczem i tym samym generuje paradoks: będąc zarazem wszędzie i nigdzie, jest konstrukcją znaną przez każdego i jednocześnie zapomnianą.

W nauce polskiej istnieją wprawdzie znakomite krytyczne opracowania dotyczące normatywizmu, jednak w żadnym nie został uwypuklony doniosły problem faz rozwojowych czystej teorii prawa. $\mathrm{Z}$ kolei zagadnienie zarachowania w normatywizmie jest zarówno w Polsce, jak i na świecie praktycznie nieznane. Niewiele można znaleźć publikacji z tego zakresu, a zwłaszcza osadzających zarachowanie w kontekście ewolucji Kelsenowskiej teorii. Sytuację komplikuje fakt, że Kelsen definiuje pojęcie zarachowania w sposób odmienny od przyjętego tradycyjnie, co może prowadzić do błędnego zrozumienia całej jego teorii. Wydaje się zatem, że warto przywrócić niezwykle bogatą intelektualnie, wielowymiarową myśl Kelsena. Ma ona wciąż wiele do zaoferowania pod warunkiem, że jest poprawnie zrozumiana. Całą sytuację komplikuje do tego fakt, że Kelsen konstruował swoją teorię przez ponad 60 lat, przez co z czasem ulegała ona licznym modyfikacjom. W rezultacie, dziś wyróżnia się trzy albo nawet cztery fazy twórczości Kelsena. Zmiany zachodzące w tej teorii mają charakter dynamiczny, przypominają opisywany w naukach przyrodniczych efekt motyla - nieznaczna zmiana jednego z elementów pociąga za sobą istotne zmiany innych.

${ }^{1}$ M. Zirk-Sadowski, Soft-Kelsenism versus Multicentrism, [w:] M. Zirk-Sadowski, M. Golecki, B. Wojciechowski (eds), Multicentrism as an Emerging Paradigm in Legal Theory, Dia-logos Peter Lang, New York 2009, s. 53; M. Zalewska, Zapomniana monografia „Ogólna teoria norm” Hansa Kelsena, [w:] O. Nawrot, S. Sykuna, J. Zajadło (red.), Konwergencja czy dywergencja kultur i systemów prawnych?, Wydawnictwo C.H. Beck, Warszawa 2012, s. 347-348.

2 M. Zirk-Sadowski, Soft-Kelsenism..., s. 53. 
Celem niniejszych rozważań jest odpowiedź na pytania: czym jest zarachowanie, jakie funkcje pełni i wykazanie, że jest to konstrukcja ważna, niesłusznie pomijana w doktrynie, ponieważ stanowi jeden z fundamentów czystej teorii prawa. Odpowiedź na pytanie o istotę zarachowania nie może zostać udzielona poprzez proste odwołanie się do definicji tego pojęcia. Ta definicja raczej się nie zmienia, podczas gdy zmienia się odpowiedź, czym jest zarachowanie. Wynika to ze ścisłego uzależnienia tego pojęcia od kontekstu, w którym występuje, czyli fazy rozwoju teorii Kelsena i sposobu, w jaki używał on towarzyszących zarachowaniu pojęć. W tym sensie analiza zarachowania przywodzi na myśl koncepcję gier językowych Wittgensteina. Poszukiwany jest sposób użycia pojęcia zarachowania zgodny z regułami danej gry. W tym przypadku reguły gry to założenia charakterystyczne dla danego okresu jego twórczości. Można powiedzieć, że Kelsen w każdej fazie w pewnym stopniu zmieniał grę językową, w rezultacie czego zmieniały się pojęcia, którymi się posługiwał. Przy próbie analizy teorii Kelsena ważne jest zatem przede wszystkim - odwołując się do wittgensteinowskich kategorii - nie znaczenie ( $w$ tradycyjnym rozumieniu tego słowa), ale użycie określonego wyrażenia. Zarachowanie w poszczególnych fazach było używane w nieco inny sposób, przez co w pewnym stopniu uległa zmianie jego istota. Zawsze jednak było ważnym składnikiem czystej teorii prawa. $Z$ tego względu tak wiele uwagi poświęciłam również innym elementom czystej teorii prawa, w szczególności dualizmowi bytu i powinności oraz pojęciu normy prawnej. Podyktowane jest to właśnie założeniem, że nie da się pojęcia zarachowania poprawnie zdefiniować w oderwaniu od kontekstu. Ci, którzy podejmowali taką próbę, wpadali w pułapkę - mylili fazy rozwojowe teorii Kelsena, neokantyzm z filozofią analityczną, zarachowanie centralne z peryferyjnym, płaszczyznę epistemologiczną $\mathrm{z}$ ontologiczną.

Kolejna trudność, na którą napotyka każdy badacz Kelsena, polega na tym, że zajmując się jego dorobkiem naukowym, nie można zapominać, że był on myślicielem badającym wiele dziedzin. W Polsce znany jest przede wszystkim jako pozytywista, najważniejszy przedstawiciel normatywizmu. Konstytucjonaliści zapewne nazwą go architektem sądownictwa konstytucyjnego. Niektórzy może określą go jeszcze jako neokantystę. Mało kto jednak wie, że Kelsen poza tym zajmował się etnologią, prawem międzynarodowym, był orędownikiem demokracji analizującym system prawa państw komunistycznych, a na gruncie filozofii interesowało go pojęcie sprawiedliwości. Na wielu z tych pól można by dokonać niezwykle ciekawych analiz dotyczących zarachowania. Na przykład, dokonana w kontekście prawa międzynarodowego, rozpoczynając rozważania od fundamentalnego z punktu widzenia czystej teorii prawa pytania, czy w ogóle jest tu dla zarachowania miejsce? Można byłoby również zagłębić się w etnologię i zbadać zasadę zadośćuczynienia (będącą jedną z odmian zarachowania). Albo sięgnąc do dogmatyk prawniczych i postawić pytanie, jak na ich gruncie opisać Kelsenowskie zarachowanie. Każde $\mathrm{z}$ tych zagadnień, aby było możliwe przed- 
stawienie ich w sposób wyczerpujący, musiałoby być przedmiotem osobnej rozprawy. I każde z nich wymaga najpierw opracowania podstaw, wypełnienia luki, która istnieje w piśmiennictwie i prześledzenia ewolucji zarachowania w Kelsenowskim normatywizmie. $Z$ tego względu konieczne wydaje się ograniczenie tematu właśnie do tego zakresu. $Z$ tego względu pominę wyżej wymienione wątki z nadzieją, że dzięki tej monografii ich podjęcie stanie się możliwe w przyszłości.

Zarachowanie znakomicie spełnia się w roli osi ogólnych rozważań. Tym samym stało się dla mnie pretekstem do przedstawienia bogactwa czystej teorii prawa jak również aktualnej dyskusji toczącej się w świecie na temat samego normatywizmu. Dyskusja ta obecnie zdominowana jest przez kilka głównych ośrodków. Austriacki, w którym główną rolę odgrywa Instytut Hansa Kelsena w Wiedniu i osoby skupione wokół niego, m.in.: Robert Walter, Clemens Jabloner, Thomas Olechowski, Gerhard Luf, Klaus Zeleny. Spoza Instytutu warto wymienić niedawno zmarłego Otę Weinbergera; amerykański, z najlepiej znaną bodajże postacią wśród kelsenistów - Stanleyem L. Paulsonem; niemiecki, w którym godnym wyróżnienia wydaje się Carsten Heidemann, autor jednej z najważniejszych książek na temat normatywizmu, czy Werner Krawietz. Do niedawna w głównym nurcie dyskusji uczestniczyło również dwóch prominentnych polskich teoretyków prawa: Kazimierz Opałek i Jerzy Wróblewski. Ponadto, ożywiona dyskusja na temat normatywizmu toczy się w Ameryce Południowej, we Włoszech, Czechach, Hiszpanii i wielu innych krajach z Japonią włącznie. Poza powyższymi nazwiskami nie można zapominać, że Kelsena komentowali i komentują najwięksi: obecnie Robert Alexy, Herbert L.A. Hart, Joseph Raz czy Alf Ross. Publikacje wyżej wymienionych to obecnie pewien kanon, ilustrujący aktualny przebieg dyskusji na temat czystej teorii prawa. Nie trzeba się z nimi zgadzać, ale należy je znać, jeśli chce się zaproponować własną interpretację.

To właśnie prace tych autorów, obok dzieł samego Kelsena, zostały w pierwszym rzędzie przeze mnie uwzględnione $\mathrm{w}$ takim zakresie, na jaki pozwala tematyka, którą zajmują się poszczególni teoretycy. Dzięki temu możliwe jest wierne zobrazowanie obecnego klimatu intelektualnego kelsenowskiego środowiska. Tej dyskusji, stanowiskom poszczególnych autorów poświęcona została duża część niniejszej monografii. Wynika to z faktu, że, jak już wspomniałam, w literaturze polskiej istnieją dobre prace bazujące na samych publikacjach Kelsena. Wydaje się natomiast, że w przypadku aktualnej dyskusji oraz tej, która toczyła się w przeszłości, występuje wyraźna luka, wynikająca zapewne z utrudnionego dostępu do tych prac.

Niniejsze rozważania dotyczące zarachowania składają się z siedmiu rozdziałów. Trzy pierwsze mają za zadanie wprowadzić czytelnika w problematykę, zaznajomić z siatką pojęciową oraz budują tło dla przyszłych rozważań na temat ewolucji zarachowania.

Pierwszy rozdział, zatytułowany: Normatywizm i jego ewolucja, ma charakter wprowadzający, stanowąc punkt wyjścia dla dalszych rozważań i uzasadnienie 
systematyki opracowania. Zawiera wyjaśnienia, czym jest normatywizm oraz pod pretekstem zarysowania słynnego sporu pomiędzy Paulsonem a Heidemannem o periodyzację, przychylając się do stanowiska Heidemanna, wpływa na dalszą strukturę rozważań, wyróżniając cztery, a nie trzy fazy, omówione kolejno w osobnych rozdziałach.

Celem drugiego rozdziału, zatytułowanego Podstawowe pojęcie normatywizmu i podstawy metodologiczne, jest umiejscowienie zarachowania na tle szerszej perspektywy, którą są główne pojęcia i założenia normatywizmu, takie jak na przykład: norma prawna czy norma podstawowa. Przedstawiono w nim również podstawy metodologiczne, mające doniosłe konsekwencje dla kształtu czystej teorii prawa. Pojęcia te zostały wyciągnięte przed nawias, ponieważ stanowią siatkę pojęciową, wspólną dla wszystkich faz, niezbędną dla prowadzenia dalszych rozważań.

Trzeci rozdział, zatytułowany Pojęcie zarachowania i jego typy, ma za zadanie wyjaśnienie samego pojęcie zarachowania. Konieczność wprowadzenia rozdziału o takim charakterze podyktowana jest $\mathrm{z}$ jednej strony tym, że Kelsen nadał pojęciu zarachowania nieco inny sens, aniżeli przyjęty powszechnie, z drugiej, ze względu na nawiązania przez filozofa prawa z Wiednia do Kanta.

Punktem wyjścia u Kelsena jest podział na nauki przyrodnicze i nauki społeczne, pochodny wobec podziału na rozum teoretyczny i praktyczny. Te pierwsze opisują porządek rzeczy albo system elementów powiązanych ze sobą przyczynowo $^{3}$, te drugie, definiowane przez Kelsena jako „,normatywny porządek ludzkich zachowań" ${ }^{4}$, również mogą podlegać zasadzie przyczynowości. Od nauk przyrodniczych będą się wtedy różnić tym, że opisują ludzkie zachowania w relacji do innych ${ }^{5}$. Według Kelsena, jeśli jednak chce się opisać zdaniami prawnymi normatywny porządek ludzkich zachowań, wówczas zasada przyczynowości nie ma zastosowania. W jej miejsce wchodzi zarachowanie ${ }^{6}$. Można tu wskazać na analogię, która ma miejsce pomiędzy obiema zasadami: analogiczna będzie ich funkcja - łącznik dwóch elementów w szeroko pojętym zdaniu. Jednak znaczenie tego łącznika jest już zupełnie inne, ponieważ, jeśli na przykład łączy się przestępstwo z karą czy też wyrządzenie szkody z odpowiedzialnością, to nie są to powiązania przyczynowo-skutkowe, sprowadzające się do schematu zdania wyrażającego konieczność: „kiedy A to B”. Zamiast tego w schemacie pojawia się powinność: „kiedy A to powinno być B", nawet wtedy, gdy B nigdy nie nastąpi? Widać zatem, jak silną inspiracją był dla Kelsena Kant, co potrafi być bardzo zwodnicze: może rodzić pokusę sięgnięcia do Metafizyki moralności czy Krytyki praktycznego rozumu i na ich podstawie dokonywania analogii. Byłoby to podejście błędne, z punktu wi-

\footnotetext{
${ }^{3}$ RR2, s. 78.

${ }^{4}$ Ibidem, s. 79.

5 Ibidem.

${ }^{6}$ Ibidem.

${ }^{7}$ Ibidem, s. 80.
} 
dzenia którego teoria Kelsena wydaje się nie mieć zbyt wiele sensu. Ważne zatem wydaje się opisanie pojęcia zarachowania, tak jak rozumiał je Kant (i rozumiane jest współcześnie), by można było uchwycić różnicę między nim a definicją Kelsenowskiego zarachowania i spełnianymi przez niego funkcjami. W rozdziale tym uwypuklono różnice zachodzące między zarachowaniem z czystej teorii prawa a zarachowaniem - nazwanym - klasycznym. Zostaną w nim zatem opisane różne rodzaje zarachowania, omówiony kontekst historyczny na przykładzie wybranych autorów (Pufendorfa i Kanta), współczesne zastosowanie tego pojęcia.

Cztery kolejne rozdziały zawierają szczegółową analizę zarachowania oraz pojęć determinujących jego funkcje i znaczenie w konkretnej fazie. Prawdopodobnie można sformułować ogólną zasadę, że wydarzenia w życiu determinują nie tylko kim jesteśmy, ale również wywierają silny wpływ na reprezentowane poglądy. W przypadku Kelsena ta teza może być postawiona w sposób szczególnie dobitny. Istnieje dość silna korelacja pomiędzy rozwojem jego teorii a zmianami, które zachodziły w jego obfitującym w zmiany życiu. Warto zatem, dla lepszego zrozumienia poszczególnych faz, zarysować ten kontekst.

Kelsen urodził się 11 października 1881 r. w Pradze, która w tamtym czasie należała do Austro-Węgier, jednak już w 1883 r. jego rodzina przeniosła się do Wiednia. Duży wpływ na jego życie miał fakt, że pochodził z żydowskiej rodziny. W celu uniknięcia ewentualnych zarzutów, iż pochodzenie wpływa na jego poglądy, w 1905 r. przeszedł na katolicyzm. Jak się później okazało, decyzja ta niewiele pomogła. Politycznie deklarował neutralność, choć sympatyzował z socjaldemokratami. Pomimo że do jego kręgu zainteresowań należały przede wszystkim nauki humanistyczne, takie jak filozofia, literatura, logika oraz matematyka, a nawet nauki przyrodnicze, to w $1906 \mathrm{r}$. obronił doktorat z prawa. Decyzja, aby studiować prawo, wynikała raczej z praktycznych kalkulacji aniżeli prawdziwego zainteresowania tą dziedziną, jednak w miarę kontynuacji studiów jego zaangażowanie rosło. W $1908 \mathrm{r}$. uczęszczał na seminarium na uniwersytecie w Heidelbergu prowadzone przez Georga Jellinka, który był autorytetem prawa publicznego. Inną osobą, która bezsprzecznie wywarła wpływ na poglądy Kelsena, był Edmund Bernazik, wybitny austriacki profesor prawa konstytucyjnego. Hans Kelsen podczas swego pobytu w Wiedniu utrzymywał również kontakty $\mathrm{z}$ wieloma osobami zaliczanymi do nurtu wiedeńskiego modernizmu, w którym szczególnie wyróżniało się Koło Wiedeńskie. Należy podkreślić, że sam do niego nie należał. Pozornie wydaje się, że można ustalić prosty związek pomiędzy poglądami Kelsena a kołem. Nie jest to do końca słuszne. Sam Kelsen twierdził, że z kołem łączyło go odrzucenie metafizyki. Zaprzeczał jednak, jakoby jego poglądy były zdeterminowane w jakikolwiek sposób poprzez koło, choć przyznawał, że pisma Phillipa Franka czy Hansa Reichenbacha taki wpływ miały ${ }^{8}$. Konkludując, wydaje się, że należałoby uznać, iż Kelsen, obracając się w tym

${ }^{8}$ Z listu Hansa Kelsena do Henka L. Muldera z 5 V 1963 r. 
samym intelektualnym środowisku, pośrednio był przez nie zainspirowany. Nie przeszkodziło mu to jednak w stworzeniu czegoś całkiem nowego.

Do tego okresu w życiu Kelsena odniosłam się przede wszystkim w czwartym rozdziale pt. Zarachowanie w fazie krytycznego konstruktywizmu. Nazwę tej fazy wyjątkowo zaczerpnęłam od Paulsona, ponieważ uznałam, że lepiej oddaje jej charakter niż ta, którą zaproponował Heidemann, czyli konstruktywizm.

Rozdział stanowi szczegółową analizę pojęcia zarachowania w pierwszej fazie rozwoju teorii prawa Kelsena. Zostało w nim opisane zarachowanie, później nazwane centralnym. Zarachowanie peryferyjne, wzbudzające o wiele większe zainteresowanie doktryny, jeszcze się nie pojawiło. Aby zachować klarowność wywodu, opisywanemu zarachowaniu już w tym rozdziale przypisałam określenie „centralnego". W tej fazie Kelsen dopiero konstruuje aparat pojęciowy. Z tego względu przytaczane przez niego definicje zarachowania są niespójne, różniąc się między sobą. Sama ich treść również nie wydaje się do końca klarowna. Wiele uwagi zatem poświęciłam na wyjaśnienie ewentualnych nieporozumień i trudności interpretacyjnych.

W tym rozdziale dokonałam również analizy relacji zarachowania centralnego do klasycznego i przyczynowości. Jest to zagadnienie ciekawe, ponieważ łącząc osobę z zachowaniem, są one w swojej konstrukcji zbliżone i na pierwszy rzut oka trudno uchwycić różnicę między nimi. Takich problemów nie ma z wprowadzonym później zarachowaniem peryferyjnym, dlatego ten temat został potraktowany w pobieżny sposób.

Kelsen po opublikowaniu rozprawy habilitacyjnej dość szybko zaczął się piąć po kolejnych szczeblach kariery. W 1919 r. został profesorem prawa administracyjnego i konstytucyjnego (ordentlicher Professor für Staats- und Verwaltungsrecht) oraz powierzono mu współtworzenie austriackiej konstytucji, która w swoich założeniach pozostała niezmieniona do dziś. W 1921 r. został sędzią Austriackiego Trybunału Konstytucyjnego. Tę funkcję pełnił do roku 1930, kiedy to z powodów politycznych został odwołany. Nasilające się ataki polityczne spowodowały, iż w tym samym roku przeniósł się do Kolonii. Jak widać, oba czynniki - zainteresowania oraz ukończone studia - zaważyły na tematyce jego przyszłych prac. Znaczenie Kelsena jako teoretyka prawa wzrosło, gdy stał się centralną postacią w tzw. Szkole Wiedeńskiej, do której zaliczali się tacy myśliciele, jak Alfred Verdross, Josef L. Kunz, Adolf Merkl i Felix Kaufmann. Była to raczej nauka prawna aniżeli filozofia prawa9 ${ }^{9}$ Jak wskazuje Bustamante y Montoro, podstawowymi założeniami Szkoły Wiedeńskiej były ${ }^{10}$ : (1) neokan-

9 W. Ebenstein, The Pure Theory of Law: Demythologizing Legal Thought, „California Law Review" 1971, vol. 59, s. 617-618; A.S. De Bustamante y Montoro, Kelsenism, [w:] P.L. Sayre (ed.), Interpretations of Mordern Legal Philosophies - Essays in Honor of Roscoe Pound, F.B. Rothman, New York 1947, s. 43.

${ }_{10}$ A.S de Bustamante y Montoro, Kelsenism, s. 44. 
towska filozofia Szkoły Marburskiej ze szczególnym uwzględnieniem dualizmu bytu i powinności; (2) absolutna czystość metody normatywnej, w szczególności od czynników socjologicznych czy psychologicznych; (3) monistyczna teoria nauki prawa oparta na normatywnej jedności; (4) identyczność państwa i prawa; (5) hierarchiczna struktura źródeł prawa; (6) podstawowe znaczenie prawa międzynarodowego. Po wojnie Kelsen stał się jeszcze bardziej wpływowym filozofem za sprawą Allgemeine Staatslehre (ASL) z 1925 r., które zostało opublikowane jako XXIII tom w Encyklopedii prawa i wiedzy o państwie (Enzyklopädie der Rechts- und Staatswissenschaft ${ }^{11}$. Był to czas, w którym Kelsen był pod ogromnym wpływem Kanta i neokantystów. Prace wtedy napisane, w szczególności pierwsze wydanie Reine Rechtslehre (RR1) przeszły do kanonu dzieł z zakresu teorii i filozofii prawa.

Do tego okresu odnosi się rozdział piąty zatytułowany Zarachowanie w fazie neokantowskiej. Stanowi on analizę pojęcia zarachowania w fazie silnych wpływów neokantowskich. Samo zagadnienie: na ile ten teoretyk prawa z Wiednia był pod wpływem Kanta, a na ile neokantystów i z której szkoły, jest zagadnieniem niezmiernie interesującym, jednak mogącym z pewnością być przedmiotem oddzielnej rozprawy. Wątki te zostały zatem jedynie zasygnalizowane.

W tym okresie Kelsen operuje już dwoma pojęciami zarachowania: peryferyjnym i centralnym. Szczególnie interesująca z punktu widzenia podjętego tematu wydaje się tu analiza zarachowania peryferyjnego w kontekście argumentu transcendentalnego. W fazie neokantowskiej Kelsen wprowadza wizję prawa jako alogicznego materiału, który zostaje uporządkowany za pomocą relatywnych kategorii a priori, dzięki którym można mówić o normach prawnych ${ }^{12}$, opierając się na założeniu, że metoda poznania konstytuuje jego przedmiot. Analiza argumentu transcendentalnego stała się dla mnie zarazem pretekstem do opisania relacji, zachodzących między powinnością, normą podstawową a zarachowaniem. Obok tego zagadnienia opisałam zarachowanie peryferyjne w swojej drugiej, typowej dla niego funkcji: operatora powinnościowego. Z kolei pojęcie zarachowania centralnego zostało przez Kelsena w tej fazie doprecyzowane. Definicja, która poprzednio nasuwała tak wiele wątpliwości, teraz stała się klarowna, a poprzez wprowadzenie teorii hierarchicznej struktury prawa nabrała nieco innego znaczenia. To zrodziło pytanie o relacje zarachowania centralnego i hierarchicznej struktury prawa, na które pod koniec rozdziału staram się odpowiedzieć. W ostatnim punkcie rozdziału podjęłam próbę ustalenia relacji pomiędzy pojęciem zarachowania centralnego a peryferyjnego i odpowiedzi na pytanie, czy możliwe jest pogodzenie tych dwóch konstrukcji.

${ }_{11}$ W. Ebenstein, The Pure..., s. 618.

12 Mowa tu o znamiennym rozróżnieniu na przepis prawny i nomę prawną, w którym norma prawna składa się z przepisów. Kelsen jednak w swoich publikacjach posługuje się nieco inną terminologią, nie używając słowa „przepis” (Vorschrift). 
W 1940 r. Kelsen dochodzi do wniosku, że wojna w Europie jest nieunikniona i emigruje do Stanów Zjednoczonych - Nowego Jorku, a w 1952 r. przenosi się do Berkeley w Kalifornii. W ten sposób styka się z nowym środowiskiem intelektualnym krajów common law. Był to pewnością dla niego szok kulturowy. Do tego miał on już wątpliwości, co do neokantowskich podstaw, w szczególności przyczynowości. Odpowiedź negatywna co do ich zasadności mogła podważyć całą konstrukcję normatywności jako analogiczną wobec przyczynowości. Jednak z drugiej strony, to zderzenie ze światem common law było korzystne dla obu stron. O ile filozofowie kontynentu europejskiego często spotykali się z zarzutem zagubienia w zbędnych i zbyt szczegółowych dywagacjach, o tyle myślicielom systemu common law czyniono zarzut nazbyt powierzchownego traktowania zagadnień teorii prawa. I tak, początkowo teoria Kelsena nie znalazła tam wielu zwolenników, jednak z biegiem czasu zdano sobie sprawę, że czysta teoria prawa ma zacznie więcej punktów wspólnych aniżeli inne teorie z kontynentu europejskiego. Szczególnie, gdy Kelsen zaczął publikować po angielsku, przepaść pomiędzy nim a amerykańskimi i brytyjskimi myślicielami znacznie zmalała ${ }^{13}$. Za pierwszy moment, w którym nastąpił zwrot $\mathrm{w}$ poglądach twórcy czystej teorii prawa, uważa się pracę pt. Vergeltung und Kausalität. Jest to praca ważna z punktu widzenia zarachowania. Kelsen wskazuje w niej, że w czasach pierwotnych nie istniało pojęcie natury w obecnym rozumieniu tego słowa. W społeczeństwie normą podstawową była zasada zadośćuczynienia (Vergeltungsprinzip), która przyjmowała brzmienie, ,jeśli jakieś zdarzenie zostanie odczute jako zło, zostanie wymierzona odpowiednia kara, natomiast jeśli zostanie odczute jako dobro, takie zachowanie zostanie wynagrodzone". Fałszywym rozumieniem powiązań była według Kelsena, na przykład, magia. Wraz z rozwojem nauki doszło jednak do emancypacji związku przyczynowo-skutkowego. Ostatecznie takie ujęcie problemu oddaliło zagadnienie przyczynowości od kantowskich interpretacji na rzecz Humowskich.

Szósty rozdział, zatytułowany Zarachowanie $w$ fazie realistycznej, dotyczy zatem modyfikacji, które zostały wprowadzone przez Kelsena po roku 1940. Jego celem jest udzielenie odpowiedzi na temat wpływu tych zmian na koncepcję zarachowania peryferyjnego (zwanego teraz po prostu zarachowaniem) i przypisania (wcześniej zarachowania centralnego). Szczególnie dużo uwagi poświęciłam problemowi zdań prawnych i wiążącej się z nimi nowej funkcji zarachowania oraz pytaniu, czy zarachowanie nadal jest możliwe jako relatywna kategoria a priori. Przypisanie natomiast zostało opisane $\mathrm{w}$ innym aspekcie, bardzo rozwiniętym $\mathrm{w}$ Reine Rechtslehre z 1960 r. (RR2) w stosunku do wcześniejszych opracowań, w aspekcie podmiotowym. Na koniec podjęłam próbę sformułowania oceny tej fazy, która doprowadziła mnie do konkluzji, że ma ona charakter przejściowy i znajduje się pomiędzy inspiracją neokantyzmem a inspiracją filozofią analityczną.

13 Ibidem, s. 618-619. 
Siódmy rozdział, zatytułowany Zarachowanie $w$ fazie analityczno-językowej, odnosi się do ostatniej fazy, w której Kelsen, w wydanej pośmiertnie Allgemeine Theorie der Normen (ATN), wprowadza dość radykalne zmiany. Dotknęły one najważniejszych założeń czystej teorii prawa, a więc na przykład dualizmu bytu i powinności czy pojęcia normy podstawowej. Kelsen wydaje się odsuwać zarachowanie na dalszy plan, wspominając o nim tylko w kilku zdaniach. ATN jest książką nieukończoną, opracowaną przez uczniów i wydaną pośmiertnie. Można zatem się spodziewać, że pewne elementy zostały nieumyślnie pominięte. Głównym zadaniem, które postawiłam sobie w tym rozdziale, jest próba rekonstrukcji pojęcia zarachowania i odpowiedź na pytanie, czym jest i jaką rolę odgrywa w ostatniej fazie. Aby taka rekonstrukcja była możliwa, poświęciłam znacznie więcej uwagi pojęciom powiązanym z zarachowaniem aniżeli w poprzednich rozdziałach. Dopiero wyjaśnienie pojęcia normy prawnej, dualizmu bytu i powinności osadzonych teraz na nowych fundamentach - filozofii analitycznej może dać odpowiedź o istotę zarachowania. Poszukuję tu również odpowiedzi na pytanie, dlaczego przypisanie w ogóle nie jest uwzględniane przez Kelsena.

Podsumowując, można zaryzykować stwierdzenie, że już nawet pobieżne przedstawienie założeń wskazuje na doniosłą rolę zarachowania w czystej teorii prawa. Zarachowanie to temat godny poświęcenia mu uwagi tak, aby przywrócić mu należną rangę. Wydaje się, że przyjęta systematyka pozwala w sposób najbardziej efektywny opisać problem ewolucji zarachowania. Struktura niniejszych rozważań zdeterminowana jest podjętym tematem, w którym można wyodrębnić dwa elementy: pojęcie zarachowania i fazy rozwoju teorii Kelsena. Ich kombinacja wydaje się wręcz narzucać taką systematykę. 



\section{Rozdzial I \\ Normatywizm i jego ewolucja}

\subsection{Ogólne pojęcie normatywizmu}

Pojęcie zarachowania może być postrzegane jako swego rodzaju oś rozważań dla tej części normatywizmu, która dziś w polskiej kulturze prawnej została usunięta w cień. To koncepcja fascynująca, bogata intelektualnie, którą warto ocalić od zapomnienia. By zrozumieć, czym jest zarachowanie, należy najpierw przedstawić założenia znane, również te należące do soft-kelsenizmu, gdyż konstrukcji zarachowania może nadać sens dopiero osadzenie jej w kontekście całej teorii. Czym zatem jest sformułowana przez Hansa Kelsena czysta teoria prawa, inaczej normatywizm? Ryszard Sarkowicz i Jerzy Stelmach wskazują, że istnieją dwie grupy odpowiedzi na pytanie: „,zym jest prawo?”. Odpowiedzi należące do pierwszej grupy wskazują na prawo jako byt o jednorodnym charakterze. Zadaniem takich teorii jest wtedy identyfikacja faktów ontologicznych, czyli na przykład opisanie prawa jako bytu językowego czy przeżycia psychicznego. Druga grupa odpowiedzi wiąże się ze stanowiskiem, że prawo jako zjawisko złożone należy badać na wielu płaszczyznach ${ }^{1}$. Normatywizm należy do tej pierwszej grupy. Jak jednak wyjaśnić to pojęcie?

Sebastian Sykuna i Jerzy Zajadło wskazują, że jeśli przyjąć za podstawę kantowski podział na rozum praktyczny i teoretyczny, to można wyróżnić dwa kierunki refleksji nad prawem: teorię prawa o charakterze analitycznym, odnoszącej się do pytania: ,jak jest?” oraz etykę prawa o charakterze normatywnym szukającej odpowiedzi, jakie prawo być powinno ${ }^{2}$. Myliłby się jednak ten, kto sugerując się nazwą, przypisałby normatywizm do tej drugiej grupy. To jedna z cech czystej teorii prawa: terminologia przyjęta przez Kelsena może nie raz wprowadzić w błąd i takim jest właśnie pojęcie normatywizmu. Czysta teoria prawa ma na celu dwa zadania: nadanie prawoznawstwu rangi prawdziwej nauki oraz uporządkowanie jego pojęć $c^{3}$. Nie opisuje zatem prawa takim, jak być powinno,

${ }^{1}$ R. Sarkowicz, J. Stelmach, Teoria prawa, Wydawnictwo UJ, Kraków 1998, s. $23-24$.

2 S. Sykuna, J. Zajadło, International Justice - Between State Sovereignty and Human Rights?, [w:] B. Wojciechowski, M. Zirk-Sadowski, M.J. Golecki (eds), Between Complexity of Law and Lack of Order, Wydawnictwo Adam Marszałek, Torun-Beijin 2009, s. 73.

${ }^{3}$ H. Kelsen, Czysta teoria prawa (Metody i pojęcia zasadnicze), oprac. T. Przeorski, [przedruk z gazety administracji policji państwowej], Warszawa 1934, s. 8-16. 
lecz takim jakim jest. To teoria o charakterze analitycznym. Trzeba więc poszukać innej charakterystyki tego, co normatywne u Kelsena. Joseph Raz na przykład wskazuje, że z normatywnym aspektem mamy do czynienia wówczas, gdy tworzy on podłoże dla określonych wierzeń, nastrojów, emocji i intencji. W przypadku prawa chodziłoby o powody przypisania określonego obowiązku podmiotowi ${ }^{4}$. Jednak, jak zwraca uwagę Paulson, i to rozumienie normatywności jest dalekie od Kelsenowskiej definicji5 ${ }^{5}$. Można je uznać za silną wersję, podczas gdy Kelsenowska nauka prawa jest normatywna w pochodnym tego słowa znaczeniu ${ }^{6}$. Czym zatem jest owo „pochodne znaczenie”? Czesław Martyniak trafnie wskazuje, że Kelsen uznał naukę prawa za normatywną, ponieważ przedmiotem jej badań jest świat powinności, do którego należą normy prawne ${ }^{7}$. Normatywizm z czystej teorii prawa, oparty na rozróżnieniu porządku przyczynowego i porządku, którego podstawą jest zasada zarachowania, rozumiany jest zatem w wersji słabej.

Z kolei nazwa, którą Kelsen nadał swojej normatywistycznej koncepcji - „czysta teoria prawa”, nawiązuje zarazem do Krytyki czystego rozumu Kanta, jak i postuluje poprawność metodologiczną, polegającą na usunięciu z nauki prawa wszelkich elementów obcych, takich jak psychologia, socjologia czy polityka ${ }^{8}$.

W interesujący sposób zdefiniował czystą teorię prawa Herbert L.A. Hart:

Czysta teoria prawa jest ogólną teorią, która w rezultacie wskazuje prawnikowi skonfrontowanemu z określonym systemem prawnym: jak [...] opisać ten system, które koncepcje mogą być przez niego zastosowane, a które nie i generalnie jaką formę [...] ten system prawa powinien przybrać aby można było o nim powiedzieć, że jest to nauka normatywna dotycząca tego systemu?

Zatem czysta teoria prawa ma za zadanie prawnikowi-praktykowi wyodrębnić prawo w takich apektach, jak: ogólność, opis systemu prawa, odpowiedni dobór koncepcji pozwalających na jego wyjaśnienie (prawdopodobnie chodzi tu o neokantyzm i później filozofię analityczną) oraz formę, którą ten system przybiera.

${ }^{4}$ J. Raz, Explaining Normativity: on Rationality and the Justification of Reason, „Ratio” 1999, vol. 12, no. 4, s. 354-355.

5 S.L. Paulson, Faktum, Wert Distinktion: Zwei-Welten Lehre und immanenter Sinn Hans Kelsen als Neukantianer, [w:] R. Alexy, L.H. Meyer, S.L. Paulson, G. Sprenger (Hrsg.), Neukantianismus und Rechtphilosophie, Nomos Verlag, Baden-Baden 2002, s. 223-226; idem, Zwei radikale Objektivirungsprogramme in der Rechtslehre Hans Kelsens, [w:] S.L. Paulson, M. Stolleis (Hrsg.), Hans Kelsen Staatslehrer und Rechtstheoretiker des 20. Jahrhunderts, Mohr Siebeck, Tübingen 2005, s. 209.

${ }^{6}$ HP I, t. 1, s. 12.

${ }^{7}$ C. Martyniak, Moc obowiązująca prawa a teoria Kelsena, [w:] C. Martyniak, Dzieła, red. ks. R. Charzyński, M. Wójcik, Wydawnictwo KUL, Lublin 2006, s. 1.

8 J. Wróblewski, Krytyka normatywistycznej teorii państwa i prawa Hansa Kelsena, PWN, Warszawa 1955, s. 18.

${ }^{9}$ H.L.A. Hart, Kelsen Visited, „University of California Los Angeles Law Review” 1963, vol. 10 , s. 712. 
Podsumowując dotychczasowe rozważania, czysta teoria prawa jest rozumiana przez Kelsena jako teoria prawnego poznania, której celem jest odpowiedź na pytanie, czym jest prawo, pozostawiając z boku kwestię, jakie być powinno bądź w jaki sposób powinno być tworzone ${ }^{10}$. Kelsen w ten sposób dąży do stworzenia nauki prawa par excellenece i poszukuje warunków, które teoria prawa musi spełnić, by zasłużyć na to miano. W tym względzie przypomina on scjentystów, którzy zadawali podobne pytania, z tym że ich poszukiwania odbywały się na płaszczyźnie bytu, podczas gdy Kelsen badał powinność. Poznanie prawa ma być zatem poznaniem naukowym. Dla Kelsena nie ma poznania prawa bez nauki prawa. Poszukiwał on twierdzeń o prawie, które byłyby prawdziwe niezależnie od tego, z jakim systemem prawnym mamy do czynienia. Każda teoria naukowa powinna być: ogólna i jednoznaczna. Jednoznaczność polegałaby tu na tym, że relacje między pojęciami są ściśle określone. Czy teoria Kelsena taka jest? Moim zdaniem jak najbardziej. Kelsen już od drugiej fazy operuje pojęciami w konsekwentny sposób, niekiedy nadając im nowe znaczenie i osadzając w kontekście innych pojęć i czyni to raczej z sukcesem. Czy jest ogólna? Na to pytanie również można udzielić twierdzącej odpowiedzi. W końcu to dlatego Kelsen pisał wyłącznie o aspekcie formalnym norm, abstrahując od treści. Po to, by wyeliminować wszystko to, co nie jest uniwersalne dla każdego systemu prawa.

Dla Kelsena, nauka prawa jest nauką normatywną ze względu na specyficzną metodę badania skierowanego na sferę powinności, nie zaś na świat rzeczywisty. Innymi słowy, Kelsena nie interesują procesy przebiegające w świadomości: wola czy wyobrażenie pewnych norm prawnych, ale normy prawne rozumiane jako wynik aktu woli czy wyobrażeń. Według Kelsena jedynie w ten sposób możliwe jest uchwycenie istoty prawa ${ }^{11}$. Przedmiotem badania normatywizmu musi być zatem prawo pozytywne w tym sensie, że analizuje się formę przepisu prawnego pomijając jego treść. $\mathrm{O}$ ile inne teorie co do zasady umiejscawiały prawo w jakimś kontekście (politycznym, psychologicznym, socjologicznym etc.) i definiowały prawo przez jego pryzmat, o tyle czysta teoria prawa postawiła sobie za cel oczyścić prawo z wszelkich elementów niemających charakteru prawnego. W taki sposób można scharakteryzować sam normatywizm. Jednak ta charakterystyka od wewnątrz nie pomaga zbytnio w osadzeniu normatywizmu przyjmując za tło inne, konkurujące z nim teorie prawa. Warto zatem dla wyjaśnienia tych wątpliwości odwołać się do rekonstrukcji dokonanej przez Hartneya i Paulsona.

Jak wskazuje Hartney, normatywizm uznaje za swoją podstawę dwa rodzaje błędów, które według Kelsena zostały popełnione przez filozofów prawa przełomu XIX i XX w. Pierwszy z nich jest błędem filozoficznym, sprowadzającym się do krytyki dwóch tendencji: metafizycznych, które przejawiają się w koncepcjach prawa natury oraz nieuznawania przez pozytywistów dualizmu

\footnotetext{
${ }^{10}$ RR2, s. 1.

${ }^{11}$ Ibidem.
} 
bytu i powinności. Drugim rodzajem błędu jest postrzeganie systemu prawa jako zbioru osobnych elementów, takich jak prawo publiczne i prawo prywatne, stosowanie prawa i tworzenie prawa, prawo państwowe i prawo międzynarodowe etc. Zdaniem Kelsena, ponad tym wszystkim można dostrzec pewną całość, pewien wspólny mianownik, do którego daje się sprowadzić wszystkie elementy, gdzie różnica dotyczy raczej stopnia niż rodzaju ${ }^{12}$.

Podobnej rekonstrukcji, tylko o wiele bardziej rozbudowanej, dokonuje Paulson. Wskazuje on, że z historycznego punktu widzenia istnieją dwa typy teorii dotyczących prawa. Po pierwsze, są to teorie prawa naturalnego biorące za punkt wyjścia moralność (teza o związku). Prawo pozytywne miałoby mieć wobec prawa naturalnego funkcję służebną i niejako zawierałoby się w zakresie moralności. Po drugie, nurtem są doktryny prawa pozytywnego, według których prawo postrzegane jest jako fakt należący do świata przyrody, zaś uzasadnienie filozoficzne jego istnienia, czy kontekst socjologiczny lub społeczny nie odgrywają większej roli. Moralność jest od prawa odseparowana (tzw. teza o rozdziale).

Do czasu powstania czystej teorii prawa teorie te były postrzegane jako uzupełniające się wzajemnie, wyczerpujące katalog możliwych rozwiązań i stanowiły to, co Paulson nazwał antynomią nauki prawa (jurisprudential antinomy) ${ }^{13}$. Kelsen, podobnie jak wcześniej Kant w przypadku racjonalizmu i empiryzmu, zauważa, że dokonanie takiego dychotomicznego podziału w przypadku filozofii prawa nie jest bynajmniej oczywiste a wyżej wymienione tezy nie są tezami sprzecznymi, a jedynie przeciwnymi. Odrzuca zatem oba rozwiązania oraz podejmuje próbę, zresztą udaną, wskazania trzeciej alternatywy ${ }^{14}$.

Punktem wyjścia jest dla niego spostrzeżenie, że de facto w nauce prawa istnieją cztery tezy, nie zaś dwie, istnieje bowiem jeszcze relacja pomiędzy prawem i faktem ${ }^{15}$. Powstają zatem dwie analogiczne konkurujące ze sobą tezy. Pierwsza z nich, zwana tezą redukcyjną, odwołująca się do teorii prawa pozytywnego, gło-

${ }_{12}$ M. Hartney, Introduction: The Final Form of the Pure Theory of Law, [w:] H. Kelsen, General Theory of Norms, trans. M. Hartney, Clarendon Press, Oxford 1991, s. XX-XXI.

${ }^{13}$ S.L. Paulson, The Neokantian Dimension of Kelsen's Pure Theory of Law, Oxford Legal Studies, Oxford University Press, Oxford 1992, s. 313.

${ }^{14}$ Ibidem, s. 314; S.L. Paulson, Lässt sich die Reine Rechtslehre transzendental begründen?, „Rechtstheorie” 1990, Bd. 21, s. 158-159. Należy zwrócić uwagę, że Paulson słusznie zarzuca Kelsenowi, że wskazując na podział między pozytywizmem prawniczym a prawem natury jako antynomicznym, dość dowolnie zakwalifikował jakże różniących się od siebie twórców do jednej lub drugiej kategorii. Jednocześnie Kelsen zredukował teorie niektórych do określonego fragmentu, aby przyporządkowanie do którejś z grup było możliwe. Jako przykład podaje Paulson Stammlera, który w pismach Kelsena jawi się empirystą ze względu na to, że wyeliminował ze swojej teorii elementy nieempiryczne. W HP Stammler staje się przedstawicielem nurtu redukcjonistycznego, opowiadającego się za powiązaniami kauzalnymi. Dzieje się tak dlatego, że Kelsen odrzuca Stammlerowską koncepcję celowości, twierdząc, że jest to jedynie zakamuflowane powiązanie przyczynowo-skutkowe (HP I, t. 1, s. 105; S.L. Paulson, Lässt sich..., s. 159-161).

15 RR2, s. 60. 
si, że prawo i fakt są ze sobą nierozerwalnie związane, a więc, że prawo należy do sfery faktów. Druga zaś, teza normatywna, charakterystyczna dla doktryn prawa natury, głosi separację między faktem a prawem ${ }^{16}$. Pozostają zatem dwie nieprzeanalizowane kombinacje: teza normatywna wraz z tezą o rozdziale oraz teza o związku wraz z tezą redukcyjną. O ile druga kombinacja nie znajduje do chwili obecnej zwolenników, pierwsza jest właśnie normatywizmem ${ }^{17}$. Na pierwszy rzut oka wydawałoby się, że normatywizm jest, tak jak Kantowska Krytyka czystego rozumu, pogodzeniem dwóch przeciwstawnych nurtów. Jednak Kelsenowi bliżej było do teorii pozytywistycznych, ze względu na niechęć do metafizyki i doktryn prawa natury będących przeszkodami w tworzeniu nauki prawa wolnej od ideologii. Swoją doktrynę postrzegał jako pewną modyfikację, ulepszenie tradycyjnych założeń pozytywistycznych. Jest to zatem zmodyfikowany pozytywizm prawniczy, w którym teza redukcyjna zostaje zastąpiona przez tezą normatywną ${ }^{18}$. Można tutaj dodać spostrzeżenie Ebensteina, że zasadnicza różnica między Kelsenem a pozytywistami sprowadza się do określenia charakteru normy prawnej. O ile dla pozytywistów jest ona zaledwie jakąś faktyczną daną, o tyle Kelsen uznaje jej absolutne istnienie ${ }^{19}$.

Jak wskazuje Paulson, odmienność czystej teorii prawa od tradycyjnych stanowisk można zobrazować za pomocą czterech pytań:

1. Czy można wyprowadzić tezę normatywną z tezy o związku? - odpowiedź w obu przypadkach jest na to pytanie twierdząca.

\section{$\mathrm{TN} \rightarrow \mathrm{TM}$}

2. Czy teza o związku jest wyprowadzana z tezy normatywnej? - tu stanowiska się różnią. Kelsen udziela odpowiedzi przeczącej, podczas gdy z tradycyjnego punktu widzenia jest to odpowiedź twierdząca.

\section{$\mathrm{TM} \rightarrow \mathrm{TN}$}

3. Czy teza o rozdziale jest wyprowadzana z tezy redukcyjnej? - tu odpowiedź będzie zawsze twierdząca.

$$
\mathrm{TR} \rightarrow \text { TRed }
$$

4. Czy teza redukcyjna jest wyprowadzana z tezy o rozdziale? - Kelsen w przeciwieństwie do tradycyjnych pozycji udziela odpowiedzi twierdzącej ${ }^{20}$.

$$
\text { Tred } \rightarrow \text { TR }
$$

O ile zatem tradycyjna nauka postrzegała relacje pomiędzy obiema grupami tez jako zachodzące w obie strony (z tezy normatywnej wynika teza o moralności, a z tezy o moralności teza normatywna, czyli na przykład przyjmując

${ }^{16}$ S.L. Paulson The Neokantian..., s. 319; idem, Lässt sich..., s. 164-165.

17 S.L. Paulson, The Neokantian..., s. 320.

18 Ibidem, s. 321.

19 W. Ebenstein, The Pure Theory of Law: Demythologizing Legal Thought, „California Law Review" 1971, vol. 59, s. 624-625; co moim zdaniem może wzbudzać pewną wątpliwość, czy w tym miejscu Kelsen, nadając normie absolutne istnienie, nie przemycił wątków metafizycznych.

20 S.L. Paulson, The Neokantian Dimension..., s. 320. 
tezę o moralności, należy jednocześnie przyjąć tezę normatywną), o tyle Kelsen powiązania widział jako zachodzące jedynie w jednym kierunku, gdzie przechodzi się z jednego zagadnienia (prawo i fakt) do drugiego (prawo i moralność). Tak wygląda Paulsonowska rekonstrukcja. Jak widać, ma ona charakter ogólny. Warto zatem zadać pytanie, w jaki konkretnie sposób Kelsen uzasadnia wybór tych dwóch z czterech tez.

\subsubsection{Teza o rozdziale i krytyka tezy o związku}

Podział na tezę o rozdziale i związku, jako główna oś dyskusji w XIX w., jest dobrze znany w doktrynie ${ }^{21}$. Konieczność odseparowania prawa i moralności wynika u Kelsena z postulatu odideologizowania nauki prawa. Zatem hartowskie twierdzenie, że prawo powinno zawierać w sobie minimum prawa natury jest nie do pomyślenia z tego względu, że takie twierdzenie może zawierać w sobie ukryte założenie istnienia zdefiniowanego treściowo systemu norm moralnych. Kelsen w kwestii moralności jest zdeklarowanym relatywistą, wskazując, że w czasie i przestrzeni obowiązywały różne porządki moralne i to, co w jednym było zakazane, w innym mogło być dozwolone. Twórca czystej teorii prawa, nie odmawiając moralności racji bytu, neguje istnienie moralności w absolutnej postaci. Moralność jest taka, jaka istnieje w świadomości ludzi, a obowiązują tylko te normy moralne, które społeczeństwo uznaje i ich przestrzega ${ }^{22}$. Do takiego uzasadnienia dodany właśnie zostaje postulat czystości nauki prawa, której miałby zagrażać brak separacji prawa i moralności ${ }^{23}$. Kelsen wskazuje, że jeśli prawo miałoby stanowić część moralności, to pokusa, aby nadać prawu walor absolutnego, mogłaby być zbyt silna, a wtedy zbyt łatwo dałoby się nim manipulować. Można byłoby mu wtedy bowiem nadać wartość bezwzględnie obowiązującego, czyniąc pojęcie sprawiedliwości synonimem pojęcia prawa ${ }^{24}$. Jedynym zatem rozwiązaniem jest - według Kelsena - separacja prawa i moralności.

Uzasadnienia tezy o rozdziale Kelsen poszukuje w różnicach pomiędzy prawem a moralnością i dochodzi do wniosku, że: po pierwsze, takim czynnikiem nie jest zachowanie, może być ono bowiem przedmiotem zarówno norm moralnych, jak i prawnych. Również nie jest takim kryterium podział na zachowanie wewnętrzne i zewnętrzne ${ }^{25}$. Rozważania te doprowadzają do wniosku, że różnica pomiędzy prawem i moralnością nie tkwi w ich treści, lecz w formie; po drugie, obowiązek moralny może powstać $\mathrm{w}$ wyniku woli własnej ${ }^{26}$. W przypadku moral-

${ }^{21}$ Zob. np. H.L.A. Hart, Positivism and Separation of Law and Morals, „Harvard Law Review" 1958, vol. 71, s. 593-629.

${ }^{22}$ RR2, s. 61-63.

${ }_{23}$ Ibidem, s. 61.

${ }^{24}$ HP I, t. 1, s. 77.

${ }_{25}$ RR2, s. 60.

${ }^{26}$ HP I, t. 1, s. 85. 
ności każde orzeczenie o zgodności lub niezgodności działania z normą moralną jest jednocześnie jej uznaniem. To założenie Kelsen przeciwstawia normie prawnej, która takiej właściwości nie posiada, a jej obowiązywanie jest niezależne od świadomości faktu obowiązywania. Norma prawna istnieje obiektywnie poza jednostką ${ }^{27}$. Później Kelsen uzna, że tym, co odróżnia normy prawne od innych norm, jest albo norma, albo zarachowanie.

\subsubsection{Teza normatywna i krytyka tezy redukcyjnej}

Teza normatywna stanowi differentia specifica wobec klasycznych doktryn pozytywizmu prawniczego. Jej podstawą jest założenie o separacji płaszczyzny powinności od płaszczyzny bytu. Konieczność takiego podziału jest znowu podyktowana chęcią odideologizowania nauki prawa, oczyszczenia jej z wątków psychologicznych czy socjologicznych, które jedynie zniekształcają obraz i sprawiają, że trudno uchwycić to, co w strukturze prawa jest istotne. Kelsen rozpoczyna swoje rozważania od dokonania podziału na świat materialny, czyli zjawisk przyrodniczych, oraz powiązany z nim świat myśli, wskazując, że człowiek nadaje określonym zjawiskom głębszy sens. Analogicznie, w świecie zjawisk prawnych określonym zjawiskom sens prawny nadaje (bądź nie nadaje) norma prawna. Ów podział, generuje nowy, na dwa rodzaje nauk: przyrodnicze i społeczne. W rezultacie, pewne czynności nabierają nowego znaczenia, gdy nada się im znaczenie prawne. Jako przykład Kelsen wskazuje osobę w todze przemawiającą, podczas gdy na sali wszyscy stoją. Gdy patrzy się na to przez pryzmat rzeczywistości prawnej, jest to sędzia wydający wyrok ${ }^{28}$. Ten sam fakt prawny można postrzegać w znaczeniu subiektywnym oraz obiektywnym. Ilustrację różnicy między prawem a faktem jest przykład tajnej organizacji, która wydała wyrok śmierci. $\mathrm{Z}$ punktu widzenia tej organizacji (znaczenie subiektywne) jest to wyrok. W znaczeniu obiektywnym jest to morderstwo ${ }^{29}$. Kelsen zauważa, że uznanie danego stanu faktycznego za stan prawnie doniosły nie wynika z zależności przyczynowych należących do świata natury, lecz z nadania mu specyficznego znaczenia prawnego poprzez normę. Oznacza to, że o tym, czy dane zdarzenie posiada charakter prawny, decydują normy ${ }^{30}$.

Zdaniem twórcy czystej teorii prawa, nawet w czasach, gdy dominowało prawo zwyczajowe, gdzie odrębność bytu i powinności nie była aż tak oczywista, właściwszym jest zaliczyć prawo zwyczajowe do sfery powinności. Uzasadnione jest to tym, że pomimo konieczności sięgania do sfery faktów w ustalaniu, co jest normą prawną, to taka norma prawa zwyczajowego ustanawia powinność

\footnotetext{
${ }^{27}$ Ibidem, s. 88-89.

${ }^{28}$ RR2, s. 2.

${ }^{29}$ Ibidem.

${ }^{30}$ Ibidem, s. 3-4.
} 
bez względu na to, jaka jest wola jednostki, której dotyczy. Gdy zatem jej treść zostaje już ustalona, to powinność prawna obowiązuje bez względu na rzeczywistość ${ }^{31}$. Wydaje się, że można to podsumować, stwierdzając, że o istocie prawa decyduje nie nośnik, który je wyraża, ale zespół omawianych przez Kelsena cech. Prawo należy zatem badać na tej płaszczyźnie: tam, gdzie rzeczywistości nadaje się w procesie myślowym specyficzny, normatywny sens. Wydaje się, że chciał on powiedzieć, że wykraczając poza te ramy nie bada się samego prawa, lecz pewną relację, na przykład, prawa i socjologii, czy prawa i psychologii.

Podsumowując tę część rozważań, można stwierdzić, że podstawowym celem normatywizmu jest obiektywizacja nauki prawnej, co w konsekwencji rodzi postawę zwalczającą koncepcje naturalistyczne w nauce prawa ${ }^{32}$ i odrzucenie zarówno teorii socjologicznych, krytykując je za usytuowanie prawa w świecie przyrody i przyczynowości, jak i teorii prawa natury, zarzucając im wyprowadzanie ze zdań prawnych postulaty etyczne ${ }^{33}$. W tym sensie, jak wskazuje Isaak I. Dore, mamy do czynienia z podwójną czystością kelsenowskiej teorii, wyrażającą się w separacji prawa i moralności, oraz dualizmu powinności i bytu ${ }^{34}$. Normatywność prawa u Kelsena nie czerpie swego źródła z prawa natury i nie polega na wydawaniu sądów o powinnych zachowaniach ludzkich i treści norm ${ }^{35}$, lecz wynika z założeń ontologicznych, uwzględniających dwa rodzaje rzeczywistości: sferę bytu i sferę powinności ${ }^{36}$.

Normatywizm jest zatem nauką opisową posługującą się zdaniami o takim charakterze, $\mathrm{z}$ tym że o ile w naukach przyrodniczych warunek powiązany jest z następstwem poprzez ,jest”, o tyle tu powiązanie następuje przez słowo ,powinien", wskazujące na zarachowanie, które wchodzi w miejsce przyczynowości. Jak wskazuje Wróblewski, czysta teoria prawa formułuje sądy, jak idealna konstrukcja prawa powinna wyglądać ${ }^{37}$. Wydaje się, że należy przyznać tu słuszność, z zastrzeżeniem, że celem Kelsena była budowa teorii uniwersalnej, aktualnej dla każdego systemu prawa. Powinność jednak zakłada brak takiej konieczności i w tym sensie takie ujęcie jest sprzeczne z intencją Kelsena. Wszystko jednak zależy od punktu widzenia: czy spojrzy się na normatywizm prawa jako na coś pierwotnego - a priori (jak chce tego Wróblewski), czy raczej jak na rekonstrukcję dokonaną na podstawie istniejącego już materiału prawnego. W pierwszym wypadku faktycznie uwidacznia się element powinnościowy.

31 HP I, t. 1, s. 77-79.

32 S.L. Paulson, Zwei radikale..., s. 205.

${ }^{33}$ HP II, s. V.

${ }^{34}$ I.I. Dore, The Epistemological Foundations of Law, Carolina Academic Press, Durham 2007, s. 600.

35 J. Wróblewski, Krytyka normatywistycznej..., s. 56.

${ }_{36}$ J. Wróblewski, The Problem of the Meaning of the Legal Norm, „Österreiches Zeitschrift für Öffentliches Recht und Völkerrecht" 1964, Bd. XIV, H. 3-4, s. 254.

37 J. Wróblewski, Krytyka normatywistycznej..., s. 60. 
Trzecia droga, rozwiązanie w swojej istocie genialne, wymagała jednak jakiegoś uzasadnienia dla jej racji bytu. O ile w pierwszej fazie wyraźnie tego elementu brakowało, to w kolejnych Kelsen sięgnął do dwóch filozoficznych wątków: (neo) kantowskiego oraz w ostatniej fazie - analitycznego. Wątki te zostaną rozwinięte w późniejszych rozdziałach.

\subsection{Problem periodyzacji}

Kelsen swoją działalność naukową prowadził ponad 60 lat w różnych ośrodkach akademickich, po obu stronach Atlantyku. Nic zatem dziwnego, że poglądy twórcy czystej teorii prawa nie były monolitem i ulegały znaczącym modyfikacjom. Nie sposób dokonać rzetelnej analizy pojęcia zarachowania przeoczając ten fakt. Zarachowanie jest wręcz jednym z bardziej jaskrawych przykładów zmian poglądów Kelsena. Zagadnienie periodyzacji należy zatem uznać za istotne z punktu widzenia struktury rozważań, stąd potrzeba jego szczegółowego omówienia i przynajmniej prowizorycznego rozstrzygnięcia kontrowersji, które się w tej materii pojawiły.

Periodyzacja definiowana przez Paulsona jako rekonstrukcja rozwoju określonej doktryny jest jednym $\mathrm{z}$ istotniejszych problemów, które pojawiają się podczas analizy dorobku Kelsena ${ }^{38}$. Jednak myliłby się ten, kto uważa, że rekonstrukcja faz należy do zadań prostych i mało kontrowersyjnych. Hasło „periodyzacja” kojarzy się kelsenistom z zaciętą dyskusją pomiędzy Paulsonem a Heidemannem dotyczącą liczby faz. Powstała po opublikowaniu przez Heidemanna monografii w 1997 r. Die Norm als Tatsache. Zur Normentheorie Hans Kelsen ${ }^{39}$, w której wyróżnił on cztery okresy twórczości Kelsena. Faza pierwsza, konstruktywistyczna, przypadałaby na rozprawę habilitacyjną Hauptprobleme der Staatslehre (HP) z 1911 r. W latach 1916-1922 ma miejsce okres przejściowy, podczas którego Kelsen stopniowo porzuca konstruktywizm na rzecz neokantowskiego podejścia $^{40}$. Faza druga - neokantowska, w której głównym dziełem jest Czysta teoria prawa rozpoczyna się w 1922 r. Faza ta trwa do 1940 r., kiedy następuje u Kelsena, „radykalny teoretyczny przełom”. Faza trzecia - realistyczna - trwa do około 1960 r., a jej głównymi dziełami są: Generalna teoria państwa i prawa (GTLS) oraz drugie wydanie Czystej teorii prawa (RR2). Charakteryzuje się ona tym, że Kelsen porzuca neokantowskie konstrukcje na rzecz realistycznego

${ }_{38}$ S.L. Paulson, Toward a Periodisation of the Pure Theory of Law, [w:] L. Gianformaggio (ed.), Hans Kelsen's Legal Theory a Diachotonic Point of View, G. Giappichelli Editore 1990, s. 11.

39 C. Heidemann, Die Norm als Tatsache. Zur Normentheorie Hans Kelsen, Nomos Verlagsgesellschaft, Baden-Baden 1997.

${ }^{40}$ Ibidem, s. 43. 
podejścia, które uwidacznia się w dwóch aspektach: po pierwsze, w koncepcji poznania, niekonstytuującego już przedmiotu poznania, a jedynie, odzwierciedlającego go; po drugie, w twierdzeniu, że obiektywizm poznania ma swoje podstawy nie w kategorii zarachowania, ale w empirycznej weryfikacji1 ${ }^{41}$. Faza czwarta językowo-analityczna rozpoczyna się w latach sześćdziesiątych, a jej symbolem jest wydana pośmiertnie w 1979 r. Ogólna teoria norm, w której można wyróżnić dwa podstawowe motywy: semantyki i pragmatyki norm oraz woluntaryzm i tezę, że logika norm jest niemożliwa.

Takie ujęcie jest przedmiotem krytyki Paulsona, który twierdzi, że w latach czterdziestych żaden „radykalny teoretyczny przełom” nie miał miejsca i proponuje własny, podział ${ }^{42}$. Faza pierwsza zwana krytycznym konstruktywizmem przypada na lata 1906-1920 i rozprawę habilitacyjną. Faza druga zwana klasyczną obejmowałaby lata od 1920 do 1960 r. Kelsen stara się w niej wprowadzić neokantowskie uzasadnienie tezy normatywnej oraz przejmuje od Merkla koncepcję hierarchicznej struktury prawa (Stufenbau), co Paulson nazywa dynamicznym zwrotem (dynamic break) ${ }^{43}$. W tej fazie ma miejsce rozróżnienie na dwa etapy: silnego oraz słabego neokantyzmu. Drugi etap charakteryzuje się wprowadzeniem elementów charakterystycznych dla empiryzmu (wpływ Davida Hume'a), sceptycyzmu oraz (jeszcze w małym stopniu) filozofii analitycznej ${ }^{44}$. Jego ukoronowaniem jest drugie wydanie Czystej teorii prawa. Z kolei przełom datuje Paulson na lata 1960-1962, kiedy to Kelsen odchodzi od neokantowskich teorii na rzecz poglądu sceptycznego ${ }^{45}$. Po 1960 r. rozpoczyna się zatem trzecia faza, sceptyczna. Kelsen odchodzi w niej od założeń normatywizmu i zwraca się w kierunku wolicjonalnej teorii prawa i wręcz wątków psychologicznych. Paulson zauważa, że wprawdzie jak na ironię, twórczość Kelsena z tamtego okresu bardzo przypomina koncepcje dziewiętnastowieczne, które zwalczał w HP, to nie można mówić o totalnej zmianie kierunku rozważań ${ }^{46}$. Fazy w ujęciu Heidemanna i Paulson ilustruje tabela 1.

${ }^{41}$ Ibidem, s. 155.

42 Ibidem, s. 154; Warto zwrócić uwagę, że również Paulson początkowo wyróżniał cztery fazy w twórczości Kelsena, nazywając je kolejno: fazą konstruktywistyczną, silną neokantowską, słabą neokantowską. Czwartej nie określił żadną nazwą. Jednak pomimo wyróżnienia czterech faz Paulson zaznacza, że trzecia faza jest raczej erozją idei neokantowskiej aniżeli czymś samodzielnym. S.L. Paulson, Toward a Periodisation..., s. 14-15.

${ }^{43}$ S.L. Paulson, Hans Kelsen's Earliest Legal Theory: Critical Constructivism, „Modern Law Review" 1996, vol. 59, s. 798.

${ }^{44}$ S.L. Paulson, Toward a Periodisation..., s. 15.

45 S.L. Paulson, Arriving at a Defensible Periodisation of Hans Kelsen's Legal Theory, „Oxford Journal of Legal Studies” 1999, vol. 19, s. 351; interesujące jest, że zmiana w poglądach u Kelsena nastąpiła na krótko po napisaniu wydania II Czystej teorii prawa.

${ }^{46}$ S.L. Paulson, Toward a Periodisation..., s. 15; por. G. Winkler, Rechtstheorie und Erkenntnislehre, Springer Verlag, Wien, New York 1990, s. 61-69. 
Tabela 1. Fazy w ujęciu Heidemanna i Paulsona

\begin{tabular}{|c|c|}
\hline Hei & Paulson \\
\hline $\begin{array}{l}\text { Faza pierwsza, konstruktywistyczna przypada- } \\
\text { łaby na rozprawę habilitacyjną HP z roku } 1911 . \\
\text { W latach 1916-1922 ma miejsce okres przej- } \\
\text { ściowy, podczas którego Kelsen stopniowo po- } \\
\text { rzuca konstruktywizm na rzecz neokantowskie- } \\
\text { go podejścia. } \\
\text { Faza druga, neokantowska, rozpoczyna się } \\
\text { w roku 1922. Głównym dziełem jest Czysta } \\
\text { teoria prawa. Faza ta trwa do } 1940 \text { r., kiedy na- } \\
\text { stępuje u Kelsena, według Heidemanna, „rady- } \\
\text { kalny teoretyczny przełom”. } \\
\text { Faza trzecia, realistyczna trwa do około roku } \\
\text { 1960 a jej głównymi dziełami są Generalna } \\
\text { teoria państwa i prawa oraz drugie wydanie } \\
\text { Czystej teorii prawa. Charakteryzuje się tym, } \\
\text { że Kelsen porzuca neokantowskie konstrukcje } \\
\text { na rzecz realistycznego podejścia: } \\
\text { 1) koncepcja poznania, które już nie konstytu- } \\
\text { uje przedmiotu poznania, a jedynie go odzwier- } \\
\text { ciedla; } \\
\text { 2) twierdzenie, że obiektywne poznania ma } \\
\text { swoje podstawy w empirycznej weryfikacji, nie } \\
\text { zaś w kategorii zarachowania. } \\
\text { Faza czwarta językowo-analityczna rozpoczy- } \\
\text { na się w latach sześćdziesiątych a jej symbolem } \\
\text { jest wydana pośmiertnie w } 1979 \text { r. Ogólna teo- } \\
\text { ria norm, koncentrująca się na: } \\
\text { 1) semantyce i pragmatyce norm, } \\
\text { 2) woluntaryzmie i w konsekwencji tezie, że lo- } \\
\text { gika norm jest niemożliwa. }\end{array}$ & $\begin{array}{l}\text { Faza pierwsza zwana krytycznym konstrukty- } \\
\text { wizmem przypada na lata 1906-1920 i rozpra- } \\
\text { wę habilitacyjną. } \\
\text { Paulson zauważa, że jeśli zostaje wprowadzony } \\
\text { okres przejściowy, to zaczął się on już w } 1913 \text { r. } \\
\text { albo w 1914, kiedy pojawiają się pierwsze ele- } \\
\text { menty zwiastujące drugą fazę, w tym konstruk- } \\
\text { cja normy podstawowej. } \\
\text { Faza druga zwana klasyczną trwa od roku } \\
\text { 1920 do 1960: } \\
\text { 1) Kelsen wprowadza neokantowskie uzasad- } \\
\text { nienie tezy normatywnej, } \\
\text { 2) przejmuje od Merkla koncepcję dynamicz- } \\
\text { nego hierarchicznego porządku norm (Stufen- } \\
\text { bau), co Paulson nazywa dynamicznym zwro- } \\
\text { tem (dynamic break). } \\
\text { Paulson w tej fazie dokonuje rozróżnienia } \\
\text { na dwa etapy: silnego neokantyzmu oraz słabe- } \\
\text { go neokantyzmu. } \\
\text { Drugi etap charakteryzuje się tym, że poza neo- } \\
\text { kantyzmem Kelsen wprowadza: } \\
\text { 1) elementy charakterystyczne dla empiryzmu } \\
\text { (wpływ D. Hume'a), } \\
\text { 2) sceptycyzmu, } \\
\text { 3) narzędzia analityczne. Ukoronowaniem tej } \\
\text { fazy było drugie wydanie Czystej teorii prawa. } \\
\text { Faza trzecia zwana sceptyczną po } 1960 \text { r., } \\
\text { w której Kelsen odchodzi od założeń Czystej } \\
\text { teorii prawa. }\end{array}$ \\
\hline
\end{tabular}

Źródło: opracowanie własne.

Gdzie tkwi zatem, według Paulsona, błąd w Heidemannowskim ujęciu? Paulson formułuje wobec Heidemanna dwa zarzuty. Po pierwsze, że Heidemann twierdzi, iż radykalny przełom w twórczości Kelsena ma za swoje podstawy fakt emigracji do Stanów Zjednoczonych, gdzie panował zupełnie inny sposób myślenia o prawie. Po drugie, że według Heidemanna, w tym czasie Kelsen zafascynowany Humem zaczyna mieć wątpliwości co do rozumienia przyczynowości na sposób kantowski (jako kategorii a priori), co uwidoczniło się w jego książce 
z zakresu antropologii Vergeltung und Kausalität ${ }^{47}$. Według Paulsona, jeśli nawet jest w tym nieco racji, to bynajmniej nie oznacza, że Kelsen odszedł od neokantowskich podstaw zarysowanych w fazie drugiej (według systematyki Heidemanna) ${ }^{48}$. Aby nie być gołosłownym, Paulson w sposób udany porównuje niektóre fragmenty kluczowe dla dyskusji z pierwszego i drugiego wydania RR2, przyznając, że zmiany dokonane w kilku szczegółach dotyczących kantowskiej doktryny, podczas szeroko rozumianej drugiej fazy, nie oznaczają, że Kelsen zmienił stanowisko na tyle, by mówić o nowej fazie, mającej swój początek w $1940 \mathrm{r}$. Takie bowiem elementy jak: jurydyczna wersja kantowskiego transcendentalnego pytania czy twierdzenie, że poznanie prawne konstytuuje swój obiekt oraz norma podstawowa jako kategoria transcendentalna pozostają bez zmian. Zamiast dwóch faz (drugiej i trzeciej) Paulson proponuje jedną podzieloną na dwa okresy, argumentując, że gdyby przyjąc podział na cztery odrębne fazy, to błędnie można by przyjąć, że faza druga i trzecia nie mają ze sobą wiele wspólnego ${ }^{49}$.

Drugim zarzutem Paulsona jest oparcie się przez Heidemanna w swojej argumentacji na dwóch przesłankach: według pierwszej $\mathrm{z}$ nich, w fazie transcendentalnej, Kelsen utożsamia sąd z przedmiotem tego sądu. Wynikałoby z tego, że jeśli sąd odnosi się do normy prawnej, to jest on tożsamy z normą i jest to centralna koncepcja transcendentalnej filozofii u Kelsena, która zostaje odrzucona w fazie realistycznej; druga przesłanka stanowi, że istnieje rozróżnienie norm prawnych i zdań prawnych ${ }^{50}$. Odnośnie do pierwszej przesłanki, Paulson zauważa, że argument ten miałby sens pod warunkiem, że Kelsen faktycznie taką tezę w fazie transcendentalnej postawił. W rzeczywistości takich słów przypisać mu nie można. Kelsen nie rozwinął wtedy teorii sądów, zaś słowo „Urteil” jest używane zarówno w fazie transcendentalnej, jak i realistycznej. Według Paulsona, Kelsen używa słowa „Urteil” w różnych znaczeniach i w jednym z tych znaczeń Kelsen utożsamia sąd i normę, ale nie ma to nic wspólnego z kantowską teorią poznania. Sąd po prostu jest normą. Rozróżnienie pomiędzy sądem a obiektem pojawia się jednak, gdy weźmie się pod uwagę drugie znaczenia słowa „sąd”, czyli to, co Kelsen później nazwie zdaniami prawnymi, w których sąd dotyczy normy i może być prawdziwy lub fałszywy, podczas gdy norma może obowiązywać lub nie. W konsekwencji prawdziwość sądu jest zdeterminowana tym, czy norma, której sąd dotyczy, obowiązuje. W fazie transcendentalnej, wskazuje Paulson, rzeczywiście Kelsen stał na stanowisku identyczności sądu i jego obiektu, ale w wyżej przedstawionym sensie, nie zaś w neokantowskim rozumieniu. Heidemann według Paulsona wysnuł zbyt daleko idące wnioski, ponieważ w pismach Kelsena nie ma dowodu na to, że Heidemannowska interpretacja jest tą

47 C. Heidemann, Die Norm als..., s. 103-104.

48 S.L. Paulson, Four Phases in Hans Kelsen's Legal Theory? Reflections on Periodisation, „Oxford Journal of Legal Studies” 1998, vol. 18, s. 159.

${ }^{49}$ Ibidem, s. 160-161.

${ }^{50}$ Ibidem, s. 162. 
właściwą ${ }^{51}$. Na koniec Paulson zarzuca Heidemannowi pominięcie kwestii dynamicznej struktury prawa, którą Kelsen przejął od Merkla ${ }^{52}$.

Odpowiedź Heidemanna na powyższe zarzuty pojawiła się na łamach „Oxford Journal of Legal Studies”. Heidemann nie zgadza się z zarzutami przedstawionymi przez Paulsona. W obronie swojego stanowiska przytoczył cztery fragmenty z publikacji Kelsena, dotyczące związku pomiędzy poznaniem i rzeczywistością, naturą norm prawnych oraz sądów w nauce prawa, identyczności tychże sądów i prawa oraz sposóbu, w jaki obowiązywanie norm jest ustanowio$n^{53} . Z$ przytoczonych fragmentów wynika teza, że poznanie kreuje swój obiekt poprzez materiał dostarczony mu przez zmysły, jednak (jak sam Heidemann przyznaje), w twórczości z tego samego (neokantowskiego) okresu można znaleźć cytaty podważające tę tezę ${ }^{54}$.

Heidemann przyjmuje również inną linię obrony, wykazując przydatność jego interpretacji, według której, skoro nie jest możliwa wiedza na temat tego, co Kant ujął jako rzeczy same w sobie, to należy przyjąć, że samo poznanie kreuje obiekt poznania. Dzieje się to poprzez tworzenie sądów, które mogą być obiektywnie ważne bez odniesienia do czegoś ponad nimi, o ile spełnione są określone warunki poznania. Przedmiot poznania nie jest bowiem zbiorem rzeczy niezależnych od wiedzy, ale systemem sądów syntetycznych, w których u Kanta kategorie, w tym przyczynowość, porządkują materiał dostarczany przez zmysły w całość. Analogicznie rzecz się ma w przypadku prawa. Przedmiot nauki prawa jest identyczny z systemem sądów stworzonych przez naukę prawa. Nauka prawa nie może w sposób pasywny opisywać norm danych przez prawodawcę, a raczej posługuje się kategorią a priori (powinności, lub zarachowania). Dzięki temu, w nauce konstruuje się sądy hipotetyczne, które są identyczne z normami prawnymi ${ }^{55}$. Podsumowując, Heidemann podkreśla, że możliwe są inne interpretacje, jeśli chodzi o fazy w twórczości Kelsena, ale jego podział jest jak najbardziej uzasadniony i przemawia za nim jego użytecznośśc ${ }^{56}$.

Paulson nie pozostawił publikację Heidemanna bez odpowiedzi. Jego polemika ujęta została w artykule Arriving at a Defensible Periodisation of Hans Kelsen's Legal Theory. Paulson odwołuje się w nim do tzw. reguły koherentności (coherence rule), która ma pomóc odpowiedzieć na pytanie, jak zmiana w trzeciej fazie sytuuje się w szerszej perspektywie oraz co w doktrynie jest ewidentne, a co budzi wątpliwości ${ }^{57}$. Według Paulsona główny problem związany z koncepcją

${ }^{51}$ Ibidem, s. 162-164.

52 Ibidem, s. 151.

${ }^{53}$ C. Heidemann, Norms Facts and Judgments. A Reply to S.L. Paulson, „Oxford Journal of Legal Studies" 1999, vol. 19, s. 346-348.

${ }^{54}$ Ibidem, s. 348.

55 Ibidem.

${ }^{56}$ Ibidem, s. 348-349.

57 S.L. Paulson, Arriving at..., s. 351-355. 
Heidemanna wynika $z$ tego, że ewolucja pojedynczego elementu teorii Kelsena służy za podstawę twierdzenia, że mamy do czynienia z nowym okresem twórczości twórcy czystej teorii prawa. Nawet jeśli Heidemann ma rację odnośnie do tego jednego elementu, to nadal pozostaje otwarte pytanie, czy to wystarcza, by mówić o nowej fazie w myśli Kelsena, ponieważ należy zadać pytanie, jak przedstawiają się inne istotne elementy: jurydyczna wersja Kantowskiego pytania transcendentalnego, poznanie prawne jako konstytutywne dla swego obiektu, zarachowanie peryferyjne jako quasi-kantowska kategoria, norma podstawowa. Według Paulsona, wszystkie wyżej wymienione elementy świadczą o tym, że mamy do czynienia z jedną fazą trwającą aż do drugiego wydania Czystej teorii prawa ${ }^{58}$. Paulson nawiązuje do tego, co napisał we wcześniejszym artykule, w którym proponował, by klasyczną fazę neokantowską podzielić na dwa okresy. Wyższość tego rozwiązania upatruje Paulson w zachowaniu odpowiednich proporcji, gdzie nacisk jest jednak położony na to co wspólne dla obu faz ${ }^{59}$.

Dodatkowo Paulson zarzuca Heidemannowi paradoksalność jego interpretacji. Z jednej strony, większość neokantowskich elementów, takich jak na przykład norma podstawowa, po $1940 \mathrm{r}$. nadal jest obecna, a z drugiej, doktryna neokantowska po 1940 r. ma być przez Kelsena porzucona ${ }^{60}$. Paulson podejmuje próbę rekonstrukcji, w jaki sposób Heidemann poradził sobie z tym paradoksem, wskazując, że przyjął on, iż Kelsen nie był gotów, aby mówić o radykalnej zmianie, której dokonał, chcąc uniknąć krytyki. Paulson zupełnie nie zgadza się z takim podejściem, zwracając uwagę, że jeśli Kelsen z jakichś powodów porzucał starą koncepcję, wyraźnie to zaznaczał ${ }^{61}$.

W kolejnym punkcie Paulson polemizuje z Heidemannem w kwestii identyczności sądu i normy. Paulson podtrzymuje twierdzenie, że powyższej tezy w dorobku Kelsena z tamtego okresu nie da się znaleźć. Cytatom przytoczonym przez Heidemanna zarzuca brak porządnej interpretacji. Wbrew temu, co sądzi Heidemann, zakwalifikowanie ich w taki sposób nie mówi samo za siebie. Aby to wykazać, Paulson ponownie zaznacza, że Kelsena używa słowa „sąd” w wielu znaczeniach, takich jak: zrekonstruowana hipotetyczna norma prawna, zdanie różne od normy prawnej (później zdanie prawne - Rechtssatz), sformułowanie normy prawnej, decyzja sędziowska, zdania pozbawionego kontekstu normatywnego. Z punktu widzenia prowadzonych rozważań, Paulsona interesuje pierwsze z pięciu znaczeń i zauważa, że wprawdzie Kelsen od początku utrzymywał, że norma jest sądem hipotetycznym, ale fundamentalne jest tutaj pytanie, co ma on przez to na myśli. Rzecz w tym, że Kelsen mówi o hipotetycznym sformułowaniu normy, które z punktu widzenia formy odpowiada hipotetycznemu sądowi

\footnotetext{
58 Ibidem, s. 352.

59 Ibidem, s. 353.

${ }^{60}$ Ibidem.

${ }^{61}$ Ibidem, s. 354-355.
} 
jako pewnej przeciwwadze dla teorii upatrujących w normie imperatywu. Norma prawna może być zrekonstruowana z zawartości wielu aktów prawnych, zatem jest sformułowana jedynie hipotetycznie, $w$ formie sądu ${ }^{62}$.

W ostatniej części artykułu, Paulson dokonuje analizy drugiego i trzeciego zaprezentowanego przez Heidemanna cytatu. Drugi cytat pochodzi z ważnego tekstu, z przedmowy do wydania drugiego HP. Paulson argumentuje, że w tym fragmencie Kelsen, mówiąc o sądzie, ma na myśli hipotetycznie sformułowaną normę prawną, natomiast cały fragment dotyczy autonomii prawa, która przejawia się właśnie w hipotecznej formie normy prawnej i zarachowaniu. Według Paulsona błędem Heidemanna było odczytanie słowa „sąd” dosłownie, podczas gdy intencją Kelsena było uwypuklenie analogii pomiędzy nauką prawa i naukami naturalnymi ${ }^{63}$.

Paulson, w przypadku trzeciego cytatu przytoczonego przez Heidemanna, stwierdza, że pojawiają się tu dwa zagadnienia. Pierwsze, omówione wyżej, dotyczy normy prawnej jako zrekonstruowanego sądu hipotetycznego. Drugim zagadnieniem jest pytanie o konstytutywną rolę nauki prawa. Kelsen twierdzi, że nauka prawa kreuje swój obiekt, zrekonstruowaną normę prawną z chaotycznego materiału prawnego, jednak wbrew temu, co twierdzi Heidemann, nie ma tu nic na temat tego, że nauka prawa tworzy samoodnoszące się sądy prawne ${ }^{64}$.

W chwili obecnej ostatnie słowo należy do Heidemanna. Po nieomal 10 latach od opublikowania artykułu Paulsona powrócił on do niezakończonej dyskusji, publikując w 2007 r. swoją kolejną odpowiedź na zarzuty przedstawione przez Paulsona ${ }^{65}$. Heidemann zarzuca Paulsonowi wiele uchybień w argumentacji. Po pierwsze, twierdzenie Paulsona, że Kelsen nigdy nie utożsamiał normy prawnej i sądu poznania prawnego, nie jest poparte żadnym przekonującym dowodem, podczas gdy Heidemann jest w stanie przytoczyć fragmenty z prac Kelsena popierających jego tezę. Ponadto, fragmenty przytoczone w poprzedniej publikacji są na tyle jasne, że nie wymagają komentarza, można je najwyżej sparafrazować. Odnośnie do argumentu Paulsona, że Kelsen słowa „sąd” używa w więcej niż w jednym znaczeniu, głównie mając na myśli warunkową strukturę ,jeżeli... to", to Heidemann zauważa, że takie ujęcie powoduje przyjęcie dwóch założeń. Po pierwsze, że Kelsen nie zdawał sobie sprawy z tego, że wyrażenie „hipotetyczny” niekoniecznie musi dotyczyć sądów i tak naprawdę miał na myśli „hipotetyczne normy” czy też „hipotetyczne imperatywy”. Po drugie, Kelsen nie zauważył, że słowo „sąd" w filozofii neokantowskiej posiadało ścisłe znaczenie mające niewiele wspólnego z warunkową strukturą zdania. Według Heidemanna

${ }^{62}$ Ibidem, s. 356-360.

${ }^{63}$ Ibidem, s. 360-362.

${ }^{64}$ Ibidem, s. 362-363.

${ }^{65}$ C. Heidemann, Noch einmal: Stanley L. Paulson und Kelsens urteilstheoretischer Normbegriff, „Archiv für Rechts-und Sozialphilosophie“ 2007, Bd. 93, s. 345-362. 
nie do pomyślenia jest, aby Kelsen wykazywał się aż taką naiwnością, aczkolwiek Kelsen słowa „sąd” używał w więcej niż jednym znaczeniu. Jednak zawsze kontekst był dostatecznie jasny. Ponadto, Paulson posiłkuje się cytatami z HP, czyli z pierwszej fazy, w której w przeciwieństwie do przedmowy do wydania drugiego pojęcie sądu nie było do końca wyjaśnione ${ }^{66}$. Argument, dotyczący twierdzenia, że poznanie prawne dotyczy norm prawnych, a nie sądów, jest dla Heidemanna niezrozumiały, popiera bowiem raczej jego stanowisko, oznaczając, że poznanie prawne ujawnia się w sądach ${ }^{67}$.

Kolejny argument Paulsona nazwał Heidemann psychologicznym i odnosi się do faktu, że Kelsen nie akcentował zmiany w swoich poglądach w latach czterdziestych, podczas gdy 20 lat później wyraźnie zaznaczył rewizję swojej teorii. Według Heidemanna nie trudno rozwiązać ową zagadkę. W latach czterdziestych Kelsen był w zupełnie innej sytuacji. Emigrował z ogarniętej wojną Europy do Stanów Zjednoczonych, gdzie dopiero musiał wyrobić sobie pozycję i nazwisko. Nie był to moment sprzyjający, by wprost podważać własną teorię. Natomiast w latach sześćdziesiątych był już nazywany „filozofem tego stulecia” i z tej pozycji mógł sobie pozwolić na wyraźne ogłoszenie zmiany poglądów ${ }^{68}$.

Heidemann, zgadza się z Paulsonem, że dla fazy neokantowskiej (klasycznej) charakterystyczne są wymienione elementy. Jednak brakuje w owym wyliczeniu dwóch dodatkowych składników. Po pierwsze, chodzi o zastosowanie przez Kelsena tzw. metody transcendentalnej; po drugie, spornej tezy dotyczącej identyczności normy prawnej i sądu prawno-poznawczego. Heidemann zauważa, że podstawową rozbieżnością w jego i Paulsona poglądach jest właśnie zagadnienie, czy faktycznie Kelsen wprowadził w swoje rozważania ową koncepcję oraz ewentualnych tego konsekwencji. Argumentację na poparcie swojej tezy rozpoczyna Heidemann od zarysowania koncepcji neokantowskich, z których czerpał Kelsen, wskazując m.in. na konstytutywną rolę poznania i zadanie transcendentalnej analizy, jakim jest ustalenie obiektywnych warunków poznania prawa. Przytaczając kolejne fragmenty, tym razem z Rechtwissenschaft und Recht ${ }^{69}$, ponownie argumentuje, że wynika z nich teza, o rzeczywistości jako przedmiocie poznania konstytuowanemu dzięki kategoriom porządkującym alogiczny materiał. Dzięki temu są tworzone sądy syntetyczne, ważne ze względu na poprawność metody zastosowanej dla ich powstania. To dlatego faktyczność jako obiekt poznania nie jest czymś od tego poznania odrębnym, lecz są to pewne sądy poznawcze, które dzięki kategorii przyczynowości nabierają sensu. Podobnie jest w przypadku prawa: nauka prawa jest identyczna z sądami konstytuującymi poznanie prawa, w których kategoria powinności, będąca w tym wypadku normatywnym zaracho-

\footnotetext{
${ }^{66}$ Ibidem, s. 356.

${ }^{67}$ Ibidem, s. 359.

${ }^{68}$ Ibidem, s. 360.

${ }^{69}$ H. Kelsen, Rechtswissenschaft und Recht, Franz Deuticke, Wien und Leipzig 1922.
} 
waniem, tak jak kategoria przyczynowości, porządkuje alogiczny materiał. Ostatecznie dla Kelsena prawo to system norm, zaś zdania prawne i normy prawne są identyczne. Te poglądy zmieniły się około roku 1940 wraz z nową ,realistyczną" definicją normy. Zasadnicza zmiana dotyczyła przede wszystkim roli sądów w poznaniu. W nowej fazie straciły one swoje konstytutywne dla nauki prawa znaczenie. Ich rola ograniczyła się wyłącznie do roli deskryptywnej, zaś obiekt już nie był przez poznanie ukonstytuowany, a jedynie poznaniu dany ${ }^{70}$. Według Heidemanna na ową zmianę miała wspomniana już wcześniej emigracja do Stanów Zjednoczonych.

Argumenty Heidemanna dotyczące tezy identyczności sądów z normami prawnymi wydają się w świetle neokantowskich konstrukcji być przekonujące. Pogląd Heidemanna jest podzielany przez Hartneya, który pisze:

Skoro zdania prawne tworzone przez naukę prawa zaledwie opisują normy prawne stworzone przez autorytety prawne, funkcja nauki prawnej jest jasna. Niejasności wcześniejszych prac zostały rozstrzygnięte na rzecz ,deskryptywnej” albo ,,pasywnej” funkcji nauki prawa, a konstruktywistyczny punkt widzenia z RR1 został porzucony. Nadal w RR1 ${ }^{71}$ można czasem trafić na stwierdzenie, że nauka kreuje swój przedmiot [...] ale wydaje się to po prostu echem przeszłości, bowiem „pasywny” punkt widzenia wygrał ${ }^{72}$.

Wydaje się, że nie ma wątpliwości co do tego, że w latach 40. Kelsen dokonał pewnej rewizji swojej teorii. Dyskusyjne jest natomiast to, czy słaba faza neokantowska zasługuje na samodzielne wyodrębnienie, czy też raczej powinna być traktowana jako jeden $\mathrm{z}$ dwóch okresów w obrębie jednej fazy neokantowskiej. Jednak, z punktu widzenia zarachowania, istnieje dostatecznie dużo pytań związanych z ewolucją poglądów u Kelsena, by ją uwzględnić w systematyce niniejszego opracowania, takich jak pytanie o status zarachowania i powinności $\mathrm{w}$ transcendentalnym argumencie, czy zarachowanie w normie prawnej i zdaniu prawnym jest tym samym zarachowaniem, a jeśli nie, to czym. Pojawia się również problem, czy do utrzymania jest dotychczasowa definicja zarachowania w obliczu zmiany pojęcia normy prawnej. Skoro sporu nie da się jednoznacznie rozstrzygnąć, to pytania te warto zadać. W systematyce uwzględniony zostanie zatem podział dokonany przez Heidemanna z zastrzeżeniem, że zachowane zostanie nazewnictwo pierwszej fazy według terminologii Paulsonowskiego, ponieważ nazwa „krytyczny konstruktywizm” wydaje się być bardziej adekwatna i trafniej oddająca ducha tego okresu.

\footnotetext{
${ }^{70}$ Ten punkt widzenia podziela Hartney. Zob. M. Hartney, Introduction..., s. XXIX.

${ }^{71}$ Autor prawdopodobnie ma na myśli RR2.

${ }^{72}$ Ibidem, s. XXXIII.
} 



\section{Rozdzial II \\ Podstawowe pojęcia normatywizmu i podstawy metodologiczne}

\subsection{Ogólny zarys podstawowych pojęć normatywizmu}

Aby można było dokonać szczegółowej analizy pojęcia zarachowania, niezbędnym wydaje się ogólne omówienie podstawowych pojęć charakterystycznych dla czystej teorii prawa. Zarówno z punktu widzenia normatywizmu, jak i konstrukcji zarachowania, niektóre z nich, na przykład norma prawna czy dualizm bytu i powinności są na tyle ważne, że omówione zostaną w niniejszej części oraz w rozdziałach odnoszących się do poszczególnych faz. W tym miejscu zostanie przedstawiona tylko ich ogólna charakterystyka, czyli to, co może zostać wyciągnięte przed nawias, tak by ich ewolucję zawrzeć w dalszych rozdziałach. Kolejno zostaną omówione: norma prawna obowiązywanie prawa i norma podstawowa, a w następnym rozdziale podstawy metodologiczne, przede wszystkim dualizm bytu i powinności.

\subsubsection{Pojęcie normy prawnej}

Kelsen twierdzi, że nauka o istocie prawa jest nauką o normie prawnej. Jest to zatem kluczowe pojęcie, którego poprawne sformułowanie jest niezbędne dla całej konstrukcji prawa ${ }^{1}$. Pojęcie normy prawnej u Kelsena zmieniało swoje znaczenie, nawet w ramach jednej fazy, Ten austriacki teoretyk prawa często przytaczał różne jego definicje. Ramy niniejszych rozważań nie pozwalają na drobiazgową analizę wszelkich odmian definicji podanych przez Kelsena, z drugiej strony, wyjaśnienie pojęcia normy prawnej jest nieodzowne dla dobrego zrozumienia konstrukcji zarachowania, którego nie da się rozpatrywać w oderwaniu od niej. Zagadnienia poruszone w niniejszym rozdziale i rozdziałach późniejszych, stanowią zatem wyraz kompromisu między tymi dwoma postulatami.

W poszukiwaniu definicji prawa Kelsen odwołuje się do rozumienia wyrażenia „prawo" w innych językach zauważając, że każde z tych wyrażeń zawierać będzie w sobie pewien charakterystyczny i niezmienny zespół cech, które być

${ }^{1}$ HP I, t. 1, s. 9; J. Wróblewski, Krytyka normatywistycznej teorii państwa i prawa Hansa Kelsena, PWN, Warszawa 1955, s. 129. 
może będą cechami konstytutywnymi dla pojęcia prawa. I tak Kelsen zauważa, że każde z tych pojęć wskazuje, że prawo jest porządkiem regulującym ludzkie zachowania, zaś porządek, to system norm, które stanowią pewną całość posiadającą jedną przyczynę obowiązywania, jaką jest norma podstawowa². Kelsen polemizuje z Austinem odrzucając jego definicję prawa w znaczeniu subiektywnego rozkazu i zamiast tego proponuje koncepcję prawa w postaci obiektywnego hipotetycznego sądu (zdania warunkowego), którym jest norma prawna. Prawo również jest definiowane jako normatywny (zawierający kategorie powinności) porządek oparty na przymusie (Zwangsordnung) ${ }^{3}$. Skoro według Kelsena prawo można określić jako zespół norm, to nauka prawa sprowadza się do nauki o normach prawnych. Jednak przy silnej ewolucji jego poglądów nie jest rzeczą łatwą, przynajmniej na pierwszy rzut oka, znalezienie wspólnego mianownika dla zmieniającego się nieustannie pojęcia normy. Przykładową definicję normy, jedną z bardziej znanych można znaleźć na początku rozważań w RR2. Norma jest tam zdefiniowana jako „coś, co powinno być lub się wydarzyć, w szczególności, że człowiek powinien się zachowywać w określony sposób ${ }^{4}$ Inna znana wersja definicji normy prawnej odwołuje się do normy prawnej jako sensu aktu woli ${ }^{5}$. Jak zatem znaleźć tę część wspólną? Klaus Adomeit rozróżnia jej trzy elementy, które, mimo pewnej niekonsekwencji, zawsze pozostają niezmienne. Po pierwsze, jest to zdefiniowanie normy prawnej jako sensu pewnego aktu. Po drugie, sens aktu ukierunkowany jest na powinność. Po trzecie, w normie prawnej zawsze występuje sankcja, czyli akt przymusu państwowego ${ }^{6}$. Poza tymi elementami z pewnością można jednak znaleźć więcej cech wspólnych. Na przykład, jak wskazuje Kelsen, normy prawne dotyczą ludzi i ich zachowań (działania lub zaniechania) lub faktów związanych z ludzkimi zachowaniami ${ }^{7}$. Zachowanie ludzkie może być uregulowane w sposób pozytywny bądź negatywny. Pozytywny aspekt zachowania polega na tym, że porządek normatywny nakazuje określone zachowanie lub zaniechanie zachowania (czyli zakazuje określonego zachowania). Wtedy osoba, której norma dotyczy, ma obowiązek się do niej zastosować. Ludzkie zachowanie jest uregulowane w znaczeniu negatywnym, jeżeli zachowanie nie jest

${ }^{2}$ RR2, s. 31-32; warto zwrócić uwagę, że Kelsen wśród cech charakteryzujących słowo „prawo" (bez względu na język, w którym to słowo funkcjonuje) dodaje pojęcie normy podstawowej, która z pewnością nie zawiera się w tymże pojęciu. Trudno sobie bowiem wyobrazić, aby wszystkie (bądź większość osób definiujących prawo) na taką cechę wskazały.

${ }^{3}$ G. Kucsko-Stadlmayer, Rechtsnormbegriff und Arten der Rechtnormen, Schriften des Hans Kelsen-Instituts, Wien 1992, s. 22-23.

${ }^{4}$ RR2, s. 4.

${ }^{5}$ ATN, s. 3.

${ }^{6}$ K. Adomeit, Der Begriff der Rechtsnorm, Schriftenreihe des Hans Kelsen-Instituts, Wien 1982, s. 171-172.

${ }^{7}$ RR2, s. 4, 12, 15. 
przez porządek prawny zabronione ${ }^{8}$. Nieco inaczej ujmuje ten problem Wróblewski, zauważając, że Kelsen pojęcia normy prawnej używa w czterech znaczeniach. Norma prawna jest przez Kelsena rozumiana jako: (1) sąd o powinności, (2) wola państwa, (3) zarys znaczeniowy zachowania ludzkiego, (4) ocena9 9

(1) W pierwszym rozumieniu, norma prawna jest sądem w logicznym sensie, z tą różnicą, że normy nie posiadają wartości prawdy lub fałszu, a jedynie można o nich mówić, że obowiązują lub nie.

(2) W drugim znaczeniu, norma prawna jest rozumiana jako „wyrażenie stwierdzające zarachowanie wszystkich norm prawnych idealnemu punktowi zarachowania, jakim jest państwo"10. Takie rozumienie normy dotyczy w szczególności pierwszej fazy, zatem szerzej zostanie wyjaśnione w dalszej części rozważań.

(3) W przypadku rozumienia normy jako zarysu znaczenia zachowania ludzkiego, Kelsen wychodził z założenia, że normy prawne nadają obiektywny sens procesom społecznym i dzięki nim można właściwie zrozumieć określone zjawiska społeczne. Jak wyjaśnia Wróblewski, takie rozumienie normy sprowadza się do stwierdzenia, że treść normy implikuje określone następstwa prawne ${ }^{11}$.

(4) W przypadku normy jako oceny, Kelsen ma na myśli porównanie zachowań człowieka, które miały już miejsce do tych opisanych w treści normy prawnej oraz ewentualnie dokonanie oceny tego stanu rzeczy (w tym wypadku niewykluczona była na przykład pozytywna ocena zachowania wbrew normie). Wróblewski zauważa, że niniejsze rozumienie przeczy założeniom normatywizmu, według których norma dotyczy potencjalnych zachowań stanowiąc ich determinant ${ }^{12}$. Jednak należy zauważyć, że Kelsen sam zaznacza pewien brak trafności takiego ujęcia, podkreślając, że wówczas norma nie może zostać użyta w jej pierwotnym celu, którym jest spowodowanie określonego stanu rzeczy bądź działania. Brak tu jest również powiązania ze stanem rzeczy, którym jest powinność, odnosząca się do przyszłości. Norma jako ocena, pełni wyłącznie rolę ,indyferentnej skali porównawczej”, przez co w tej funkcji de facto nie może być normą w kelsenowskim znaczeniu ${ }^{13}$.

${ }^{8}$ Ibidem, s. 15-16; jak wskazuje Wróblewski, Kelsen w swoich badaniach nad prawem raczej omija zagadnienie celu normy odrzucając postulat dokonywania badań nad prawem za pomocą metody celowościowej. Jest to uzasadnione to w trojaki sposób: Po pierwsze, związek środka i celu jest związkiem przyczynowym, zatem należącym do sfery bytu. Po drugie, środek i cel można odpowiednio przyporządkować formie i treści, gdzie cel odnosi się do treści (a Kelsena interesowała forma). Po trzecie, cel ma zabawienie psychologiczne, ponieważ wiąże się z pojęciem woli. Wróblewski podsumowuje, że Kelsen wyeliminował pojęcie celu społecznego, przedstawione powyżej, by zastąpić je pojęciem celu prawnego. Jest to wola państwa wykonania sankcji, w sytuacji, gdy nie został spełniony cel społeczny (J. Wróblewski, Krytyka normatywistycznej..., s. 151-152).

9 Ibidem, s. 123-124.

${ }^{10}$ Ibidem, s. 134.

${ }^{11}$ Ibidem, s. 136.

12 Ibidem.

13 Ibidem, s. 137. 
Definicja normy prawnej uzasadnia jej strukturę. Kelsen wyróżnia dwa typy norm: normę pierwotną i normę wtórną. W przeciwieństwie do pozytywistów norma wtórna u Kelsena stanowi dyspozycję określonego zachowania, natomiast norma pierwotna zawiera sankcję $\mathrm{w}$ razie niewypełnienia dyspozycji normy pierwotnej. Obie mogą wchodzić w skład normy podwójnej (Doppelnorm). Taka konstrukcja jest uzasadniona dążeniem do pozbycia się wszelkich wątków psychologicznych z czystej teorii prawa poprzez eliminację podmiotu, którym jest jednostka ludzka. Zamiast tego, w normie pierwotnej, jako podmiot pojawia się państwo. Kelsen nie uznawał na przykład za pierwotną normy „nie wolno kraść” (norma wtórna, sekundäre Norm), tylko normę: „kto kradnie, powinien zostać ukarany" (norma pierwotna - primäre Norm) ${ }^{14}$. W ATN Kelsen ujmował tę kwestię w następujący sposób:

Każda norma generalna jest połączeniem dwóch norm, z których jedna ustanawia określone postępowanie jako powinność podmiotu prawa, druga natomiast ustanawia powinność zastosowania będącego przedmiotem warunku aktu przymusu przez organ prawny w przypadku naruszenia pierwszej normy. Tę drugą określiłem jako normę pierwotną, a pierwszą jako wtórną ${ }^{15}$.

Wróblewski zarzucił w tym kontekście Kelsenowi, że taka konstrukcja mająca w założeniu służyć „czystości” teorii prawa, w rzeczywistości prowadzi do tego, że „prawo jako technika społeczna jest celem samym w sobie” ${ }^{16}$. Wydaje się jednak, że jeśli Kelsenowi chodziło o stworzenie teorii prawa, takiej, która czyni zadość warunkom nauki, czyli przede wszystkim ogólności i jednoznaczności, to jego pomysł, by opisać prawo za pomocą norm sprzężonych, gdzie norma pierwotna to norma odnosząca się do organu, jest trafiony. Konsekwencja, na którą wskazuje Wróblewski, raczej wynika z tego, że Kelsen osadza swoją teorią w świecie powinności, przy zakazie wszelkich odniesień do bytu. Czy jednak z tego wynika, że prawo jest celem samo w sobie? Może raczej to, że nauka prawa nie jest w stanie udzielić odpowiedzi o poszczególnych celach prawa, ponieważ te należą do sfery faktów i są uzależnione od miejsca i czasu, w którym prawo obowiązuje. Można oczywiście na to odpowiedzieć, że przecież wyróżnia się ogólne funkcje prawa, jak regulacja konfliktów, dystrybucja ciężarów i dóbr, czy kontrola zachowań. Jednak, takie ujęcie z kolei nie wyklucza się z zaproponowaną konstrukcją norm sprzężonych.

Do podziału na normę pierwotną i wtórną odnosi się pojęcie idealnej formy normy prawnej, którą można zobrazować według następującego schematu ${ }^{17}$ :

${ }^{14}$ G. Kucsko-Stadlmayer, Rechtsnormbegriff..., s. 25; J. Wróblewski, Krytyka normatywistycznej..., s. 139.

15 ATN, s. 43.

16 J. Wróblewski, Krytyka normatywistycznej..., s. 140.

17 ASL, s. 49. 
Jeżeli $M h+E$ (albo $M u+E$ ) to $Z \rightarrow M$,

gdzie: $M$ to zachowanie ludzkie, $M h$ działanie, $M u$ zaniechanie, $E$ zdarzenie, $Z$ akt przymusu. Należy przy tym założyć, że akt przymusu jest skierowany przeciw człowiekowi, który doprowadził do zdarzenia przez działanie lub zaniechanie ${ }^{18}$. Norma taka, jak zauważa Wróblewski, składa się z hipotezy i sankcji, nie zawierając dyspozycji, która została przeniesiona z normy pierwotnej do normy wtórnej ${ }^{19}$. Idealna forma normy prawnej została również zrekonstruowała przez Paulsona w artykule An Empowerment Theory of Legal Norm ${ }^{20}$. Paulson wskazuje, że wprowadzając taką konstrukcję, Kelsen miał na celu wyeliminowanie wątków nawiązujących do sfery faktów i moralności. Norma prawna dla Kelsena opiera się na powinności skierowanej nie do obywatela, który ma przestrzegać prawa, a tylko do organu stosującego prawo. Według niego:

egzekucja sankcji jest nakazana [...] kiedy jej zaniechanie jest uczynione warunkiem (innej) sankcji. Jeśli tak nie jest, to może ona jedynie funkcjonować jako uprawnienie, nie zaś jako nakaz ${ }^{21}$.

Kelsen nadmienił jednocześnie, że w takiej sytuacji ostatnia sankcja i tak musi być uprawnieniem, (a nie nakazem), w przeciwnym wypadku miałby miejsce nieskończony ciąg sankcji. Powinność według Paulsona może w związku z tym przyjąć albo słabą, albo silną postać. Słaba postać przybiera formę:

Jeśli obywatel $\mathrm{O}$ nie uczyni $\mathrm{x}$, to określony organ A jest umocowany do tego, by nałożyć określoną sankcję y na $\mathrm{O}^{22}$.

Silna postać zawiera w sobie dodatkowy element sankcji wobec organu, który tego nie uczyni:

Jeśli obywatel O nie uczyni x, to określony organ A jest umocowany do tego, by nałożyć określoną sankcję y na $\mathrm{O}$ i jeśli organ A nie nałoży sankcji na $\mathrm{O}$, to określony organ $\mathrm{B}$ jest umocowany do nałożenia sankcji na $\mathrm{O}^{23}$.

Należy zauważyć, iż to drugie umocowanie jest na wyższym szczeblu hierarchii prawa.

Początkowo Kelsen uznawał wyłącznie ten schemat. Dopiero później stwierdził, że nie każda norma prawna musi posiadać właśnie taką strukturę, szczególnie, że w przypadku norm indywidualnych można mówić jeszcze o normach

18 J. Wróblewski, Krytyka normatywistycznej..., s. 142-143.

19 Ibidem, s. 143.

20 S.L. Paulson, An Empowerment Theory of Legal Norm, „Ratio Juris” 1988, no. 1, s. 58-70.

${ }^{21}$ RR2, s. 26.

${ }^{22}$ Ibidem, s. 65.

${ }^{23}$ Ibidem. 
bezwarunkowych (np. wyrok sądu skazującego przestępcę na karę pozbawienia wolności $)^{24}$. I tak w ATN ów schemat ulega modyfikacji. Jak wskazuje Thomas Fritzsche ${ }^{25}$, występują w nim dwie normy:

zabronione jest doprowadzać do stanu faktycznego T [...] jeśli zostanie doprowadzone do T, określony organ powinien zostać upoważniony ${ }^{26}$ do nałożenia sankcji.

Widać wyraźnie, że ów schemat odnosi się do normy pierwotnej i wtórnej. Pierwsza norma ma jedynie charakter pomocniczy, podczas gdy druga pełni zasadniczą funkcję. Różnica między schematem zaprezentowanym w ostatniej fazie a wcześniejszym polega na zmianie funkcji normy, w której został przeniesiony nacisk z powinności na nadanie kompetencji

W teorii Kelsena, istnieje również, konkurujące z idealną formą normy prawnej, pojęcie normy kompletnej (całkowitej, pełnej - vollständig). Owa norma jest pełna, jeżeli zawiera w sobie wszystkie elementy niezbędne dla wykonania aktu przymusu. Fritz Schreier wskazuje tu na stan faktyczny, podmiot obowiązku, powinne zachowanie i sankcję ${ }^{27}$. Jako przykład podaje Kelsen jej brzmienie w przypadku kradzieży:

jeśli organ, któremu prawodawstwo nadało ku temu kompetencję, ustanowi normę generalną, że kto kradnie, ten zostanie w odpowiedni sposób ukarany, i kiedy na podstawie zasad postępowania karnego właściwy sąd w odpowiednim postępowaniu karnym ustali, że określony człowiek popełnił przestępstwo kradzieży, wówczas odpowiedni organ powinien karę wykonaće ${ }^{28}$.

Oznacza, to, że wszelkie normy zawarte w konstytucji, normy prawa materialnego, czy też proceduralnego, nie są normami pełnymi, a jedynie warunkami, jakie muszą zostać spełnione, aby było możliwe nałożenie sankcji na konkretną osobę. Na powyższym przykładzie wyraźnie widać, że w owej normie występuje głównie upoważnienie, nie zaś nakaz. Fritzche zauważa, że chodzi tu o „redukcję upoważnienia do stanowienia prawa do upoważnienia do urzeczywistnienia prawa" ${ }^{29}$. W doktrynie jednak raczej przyjęła się konstrukcja idealnej formy normy prawnej. Pełna norma prawna z pewnością jest tworem kontrowersyjnym, choćby

\footnotetext{
${ }^{24}$ Ibidem.

${ }_{25}$ T. Fritzsche, Die Reine Rechtslehre im Lichte des Kritischen Rationalismus, Schriftenreihe des Hans Kelsen-Instituts, Wien 2002, s. 32-33.

${ }^{26}$ Albo powinno być mu nakazane. Jednak, jak zostanie to wyjaśnione poniżej, ostatecznie na końcu łańcucha nakazów musi znaleźć się upoważnienie. Jak wskazuje Fritzsche, tak naprawdę, uregulowane jest jedynie zachowanie ostatniego organu, tego upoważnionego, w którego gestii leży zadecydowanie, czy dany stan faktyczny powinien zostać spełniony, czy zabroniony (ibidem).

${ }^{27}$ F. Schreier, Rechtsnorm und Rechtssatz, Schriftenreihe des Hans Kelsen-Instituts, Wien 1982, s. 211.

${ }^{28}$ RR2, s. 57-58.

29 T. Fritzsche, Die Reine Rechtslehre..., s. 38; więcej na ten temat: C. Kletzer, Reflections on Hans Kelsen's Positivism, http://www.kletzer.com/assets/pdf/master.pdf [16 VII 2010], s. 12-25.
} 
ze względu na pytanie: „co z warunkami odnoszącymi się do sfery faktów, czy nie doprowadzają one do przełamania dualizmu bytu i powinności”? Z drugiej jednak strony, pojęcie pełnej normy prawnej może, jak się później okaże, być pomocne dla wyjaśnienia relacji, które zachodzą między zarachowaniem peryferyjnym a centralnym.

Nieodłącznym elementem normy prawnej jest przymus, który odróżnia ją od norm innego rodzaju. Przymus nie należy do sfery faktów, ale do treści normy. W ten sposób, jak zauważył Wróblewski, Kelsen odciął się od ewentualnych rozważań dotyczących aparatu przymusu ${ }^{30}$. Przymus związany jest z pojęciem sankcji (przymus w porządku prawnym przybiera charakter sankcji) ${ }^{31}$. Dokonując analizy tego pojęcia, Kelsen rozpoczyna od zdefiniowania porządku społecznego, jako „normatywnego porządku, który reguluje ludzkie zachowania, dotyczące bezpośrednio lub pośrednio, innych ludzi" ${ }^{32}$. Porządkiem społecznym będzie zatem zarówno moralność, jak i prawo pozytywne, natomiast nie będzie nim na przykład logika. Funkcją takiego porządku jest skłonienie ludzi do pożądanych zachowań. Określony typ porządku społecznego może wiązać określone konsekwencje (nagroda lub kara) z jego nieprzestrzeganiem. Nagrodę i karę określa Kelsen pojęciem sankcji, zaznaczając jednocześnie, że z reguły jako sankcja występuje kara. Czym jednak jest kara? Jak słusznie wskazuje Bartosz Wojciechowski, ,kara pokazuje, że zachowanie sprawcy było sprzeczne z fundamentalnymi wartościami i prawami społeczności, do której on należy"33. Jednak Kelsen tak kary zdefiniować by nie mógł, gdyż ta definicja stanowi odniesienie do świata bytu. Dla Kelsena kara (przymus) jest reakcją na naruszenie normy wtórnej. Innymi słowy, konstrukcja Kelsena oznacza, że jeśli określone zachowanie pociąga za sobą sankcję, to zachowanie przeciwne jest nakazane:

Powinnościowe bycie sankcji (Gesollt-sein der Sanktion) zawiera w sobie należący do sfery bytu zakaz określonego zachowania, którego specyficznym warunkiem jest to, że jego przeciwieństwem jest należący do sfery bytu nakaz ${ }^{34}$.

Warto przyjrzeć się temu zdaniu i podjąć próbę odpowiedzi na pytanie, co Kelsen miał na myśli, odnosząc sankcję zarówno do sfery powinności, jak i bytu, natomiast nakaz i zakaz do sfery bytu. Twierdzenie, że nakaz i zakaz należą do sfery bytu, rodzi wątpliwość, ponieważ zarówno nakaz, jak i zakaz nie są niczym innym jak dyspozycją. Jak więc to wyjaśnić? Kelsen w dalszej części wywodu zdecydowanie podkreśla, że nakazane zachowanie nie jest powinnym

30 J. Wróblewski, Krytyka normatywistycznej..., s. 149.

${ }^{31}$ RR2, s. 36.

32 Ibidem, s. 25.

${ }_{33}$ B. Wojciechowski, Justifying Punishment In Multicultural Societies, [w:] B. Wojciechowski, M. Zirk-Sadowski, M.J. Golecki (eds), Between Complexity of Law and Lack of Order, Wydawnictwo Adam Marszałek, Toruń-Beijin 2009, s. 291.

${ }^{34}$ RR2, s. 25-26. 
zachowaniem ${ }^{35}$, a zatem o żadnej nieścisłości nie może być mowy. Rozwiązaniem tego problemu może być stwierdzenie, że Kelsen dopuszczał istnienie jedynie dwóch elementów normy prawnej: hipotezy i sankcji. Wówczas nakaz określonego zachowania w sferze bytu oznaczałby $w$ istocie jedynie, że jego przeciwieństwo byłoby warunkiem sankcji należącej do sfery powinności. W owym schemacie powinność nie dotyczy określonego działania, lecz sankcji. Nakaz czy zakaz to jedynie refleks kompetencji danego organu. Za taką interpretacją opowiada się Fritzsche, stwierdzając: „nakazane Sein zachowania oznacza, że przeciwieństwo tego zachowania jest warunkiem powinnej sankcji”"36.

Dalej Kelsen wyjaśnia, że:

egzekucja sankcji jest nakazana [...], kiedy jej zaniechanie jest uczynione warunkiem (innej) sankcji. Jeśli tak nie jest, to może ona jedynie funkcjonować jako uprawnienie, nie zaś nakaz ${ }^{37}$.

Kelsen w tym kontekście jednocześnie nadmienia, że w takiej sytuacji ostatnia sankcja i tak musi być uprawnieniem, nie zaś nakazem, w przeciwnym wypadku bowiem miałby miejsce nieskończony ciąg sankcji. Sankcja w prawie według Kelsena ma charakter przymusowy i implikuje przymusowość porządku prawnego. Akt przymusu jest nie tylko reakcją na określone ludzkie zachowania, ale również jest skierowany ogólnie, przeciwko niepożądanym stanom faktycznym, które same w sobie nie mogą być nakazane lub zakazane ${ }^{38}$. Sam moment przymusu definiuje Kelsen jako:

okoliczność, iż konsekwencją porządku (społecznego) za szkodliwe społecznie czyny przewidziane jest działanie wbrew woli osób, których ten akt dotyczy oraz, w przypadku oporu, zastosowanie sily ${ }^{39}$.

Jak wskazuje Zirk-Sadowski, przymus jako treść normy wyrażającej się $\mathrm{w}$ uprawnieniu do zmuszania, dzięki konstrukcji norm sprzężonych, pełniąc rolę normy sankcjonującej, nabiera charakteru normatywnego ${ }^{40}$. Warto dodać, że wprawdzie $\mathrm{w}$ większości przypadków zastosowanie przymusu wiąże się z działaniami społecznie niepożądanymi, to jednak istnieją przypadki, gdy to powiązanie nie występuje. Przykładem może być zastosowanie aresztu wobec osoby podejrzanej. Wówczas byłaby to sankcja w szerszym znaczeniu ${ }^{41}$.

\footnotetext{
35 Ibidem, s. 26.

36 T. Fritzsche, Die Reine Rechtslehre..., s. 31.

${ }^{37}$ RR2, s. 26.

38 Ibidem, s. 27.

39 Ibideme, s. 36.

${ }^{40}$ M. Zirk-Sadowski, Soft-Kelsenism versus Multicentrism, [w:] M. Zirk-Sadowski, M. Golecki, B. Wojciechowski (eds), Multicentrism as an Emerging Paradigm in Legal Theory, Dia-logos Peter Lang, New York 2009, s. 54-55.

${ }^{41}$ RR2, s. 41-43.
} 
Na koniec Kelsen zaznacza, że z punktu widzenia prawa nie są istotne motywy, dla których porządek prawny jest przestrzegany (jednym z takich motywów może być obawa przed sankcją, choć wcale nie musi). Patrząc przez pryzmat normatywnej skuteczności porządku prawnego, ten fakt jest pozbawiony znaczenia w przeciwieństwie do kauzalnej (przyczynowo- skutkowej) skuteczności porządku prawnego ${ }^{42}$. Kelsen zwraca uwagę, że nie należy mylić motywu skłaniającego do przestrzegania prawa, jakim jest obawa przed sankcją, która stanowi swego rodzaju przymus psychiczny, z przymusem jako cechą porządku prawnego ${ }^{43}$. W związku z problemem sankcji Kelsen stawia pytanie, czy może istnieć porządek społeczny sankcji pozbawiony? W tym kontekście twórca czystej teorii prawa analizuje porządek moralny i dochodzi do konkluzji, że porządki społeczne różnią się jedynie rodzajem sankcji, nie zaś ich istnieniem bądź brakiem ${ }^{44}$.

Wyczerpująca krytyka normy prawnej nie mieści się w ramach podjętych tu rozważań, jednak warto przytoczyć słowa Zirk-Sadowskiego, które ukazują zupełnie inną odpowiedź na pytanie, czym jest norma prawna:

Rozwijane dotychczas koncepcje normy prawnej abstrahowały prawie całkowicie od jej kulturowej genezy i kulturowych prawidłowości funkcjonowania. Tymczasem, bez uwzględnienia konkretnej relacji między porozumiewającymi się ludźmi, czyli całego kontekstu zachowania się, możemy popaść tylko w kolejny rodzaj „fetyszyzmu naukowego ${ }^{45}$.

Według Autora cytatu, normy można zdefiniować dopiero, gdy po pierwsze, zostaną zrelatywizowane poprzez umiejscowienie ich w kontekście kulturo$\mathrm{wym}^{46}$, po drugie, zbadane w modelu aktu komunikacji językowej, na poziomie pragmatyki, co pozwala je zidentyfikować jako rolę semiotyczną danej wypowiedzi w funkcji perswazyjnej. Normę wówczas można ująć jako wydarzenie, tak jak zresztą sam język, w którym normy są wyrażane ${ }^{47}$. Wydaje się, że w świetle przyjętego przez Kelsena dualizmu bytu i powinności oraz postulatu czystości metody jego teoria musi być praktycznie pobawiona wątków kładących nacisk na komunikację. Tym, co odróżnia normy od innych wypowiedzi, jest ich specyficzna struktura, osadzenie w świecie powinności, czego wyrazem jest zarachowanie $\mathrm{w}$ roli powiązania analogicznego do przyczynowości. To zupełnie inny tor myślenia, w którym uwzględnienie kulturowego kontekstu pozbawiłoby czystą teorię prawa miana czystej. Z drugiej strony, warto zauważyć, że Kelsen

${ }^{42}$ Ibidem, s. 28.

43 Ibidem, s. 36.

${ }^{44}$ Ibidem, s. 29.

${ }^{45}$ M. Zirk-Sadowski, Norma prawna jako kategoria pragmatyczna, „Zeszyty Naukowe Uniwersytetu Łódzkiego" 1980, S. I, nr 55, s. 83.

46 Według autora cytatu wymiar kulturowy został uchwycony dopiero przez wyrafinowany pozytywizm H.L.A. Harta w postaci wewnętrznego aspektu reguły (M. Zirk-Sadowski, Prawo a uczestniczenie w kulturze, Wydawnictwo UŁ, Łódź 1998, s. 36-37).

${ }^{47}$ Ibidem, s. 83-101. 
bardzo zgrabnie uniknął wikłania się w wątki kulturowe czy też w faktyczność. To, co może się jawić jako słabość jego teorii, jest zarazem gwarancją, przynajmniej w tym zakresie, jej spójności. W jakimś sensie ów kontekst kulturowy nie jest Kelsenowi potrzebny do badań nad normą prawną, jednak pod warunkiem, że uwzględni go ktoś inny, posługujący się inną metodą.

\subsubsection{System prawa i jego obowiązywanie}

W kontekście Kelsenowskiej teorii Zirk-Sadowski trafnie zauważył, że:

prawodawstwo jako nauka normatywna nie może być sprowadzone do badania odseparowanych norm, ale zawsze jest ich systemem ${ }^{48}$.

Kelsen nie od razu był w pełni tego świadom. Rozważania dotyczące systemu prawa nabrały szczególnej doniosłości dopiero w drugim i kolejnych etapach naukowej działalności Kelsena, gdy wprowadził hierarchiczną strukturę prawa. W pierwszej fazie uwzględniony jest jedynie statyczny aspekt prawa, co później Kelsen, szczególnie pod wpływem koncepcji Merkla, uznał za błąd. Z tego względu, dynamiczna struktura prawa zostanie szczegółowo omówiona w późniejszych rozdziałach.

Według Kelsena system prawny jest uporządkowanym przez naukę zbiorem norm posiadającym wspólną podstawę obowiązywania ${ }^{49}$. Można zatem wyróżnić dwa istotne elementy: uporządkowanie, które można utożsamiać z dynamiczną strukturą prawa, oraz obowiązywanie, które odgrywa znaczącą rolę w normatywizmie, jako „specyficzna egzystencja normy prawnej" ${ }^{50}$. Jest ono uzależnione od tego, czy ustawa (niezależnie od faktów) została w sposób ważny wydana. To powoduje, że jedyną odpowiedzią na pytanie, dlaczego norma prawna obowiązuje jest albo stwierdzenie, że ze względu na ustanowioną w niej powinność albo wskazanie normy hierarchicznie wyższej, która uprawnia autorytet do wydania odpowiedniej normy ${ }^{51}$. Wynika z tego, że obowiązywanie pełni taką samą rolę wobec powinności, jaką istnienie w stosunku do bytu. Nie należy jednak mylić pojęcia obowiązywania (Geltung) należącego do sfery powinności z pojęciem skuteczności (Wirkung), które odnosi się do bytu. Różnicę tę można wyjaśnić poprzez odwołanie się do konstrukcji przyczynowości. Niezbędne jest tu odróżnienie warunku koniecznego (conditio sine qua non) od przyczyny (conditio per quam). Pewien stopień skuteczności prawa nie jest przyczyną jego obowią-

${ }^{48}$ M. Zirk-Sadowski, Soft-Kelsenism..., s. 55.

${ }^{49}$ C. Heidemann, Die Norm als Tatsache. Zur Normentheorie Hans Kelsen, Nomos Verlagsgesellschaft, Baden-Baden 1997, s. 32; J. Wróblewski, Krytyka normatywistycznej..., s. 160.

${ }^{50}$ RR2, s. 9-10.

51 J. Wróblewski, Krytyka normatywistycznej..., s. 160-161; C. Heidemann, Die Norm als..., s. 32 . 
zywania, ale warunkiem koniecznym ${ }^{52}$. Obowiązywanie zatem to coś więcej niż skuteczność albo odpowiednik skuteczności należącej do sfery bytu w świecie powinności. Jeśli taka konstrukcja jest słuszna, to można się zapytać, co jest łącznikiem, pomostem między bytem a powinnością? Co pozwala na takie płynne przejście od obowiązywania do skuteczności? Wydaje się, że łącznikiem takim może być zarachowanie centralne. Obowiązywanie normy prawnej pozwala na dokonanie zabiegu powiązania stanu faktycznego (sfera bytu) do określonego podmiotu (sfera powinności), zaś kolejnym etapem będzie kwestia jej skuteczności. Pomimo tego, że skuteczność jest w pewnym stopniu niezbędna dla obowiązywania normy prawnej, to norma prawna, która ma zagwarantowaną całkowitą skuteczność i nie może zostać naruszona (np. ziemia ma się kręcić wokół słońca) również pozbawiona jest sensu. Aby norma obowiązywała, musi istnieć możliwość jej naruszenia ${ }^{53}$. Kelsen słusznie zatem zauważa, że aby porządek prawny obowiązywał, musi istnieć takie „napięcie” miedzy bytem a powinnością, aby nie osiągnęły one ani pewnej wartości maksymalnej, ani minimalnej. Nie można mówić o obowiązywaniu porządku prawnego zarówno wtedy, gdy norma prawna jest niemożliwa do spełnienia (słońce ma się kręcić wokół ziemi), jak i wówczas, gdy treść normy prawnej przedstawia konieczność (ziemia ma się kręcić wokół słońca). Zatem porządek prawny musi się zawierać między pewnym minimum a maximum skuteczności. Pochodną tego stwierdzenia jest to, że prawo obowiązuje nie dlatego, że jest to jego właściwość bądź efekt zgodności z normami prawa natury, ale tylko z tego względu, że w razie naruszenia dyspozycji normy prawnej państwo reaguje aktem przymusu ${ }^{54}$. W kontekście obowiązywania, Kelsen zauważa, że generalne normy prawne są poprzez egzekucję (wprowadzenie sankcji w życie), „uaktualniane" 55 .

Obok obowiązywania, drugą cechą charakteryzującą system norm prawnych jest uporządkowanie. Zagadnienie to jest związane $\mathrm{z}$ pojęciem hierarchicznej struktury prawa. Najkrócej rzecz ujmując, normy prawne tworzą jeden porządek o powiązaniach formalnych, które ostatecznie prowadzą do wspólnej i pierwotnej podstawy obowiązywania - normy podstawowej. Powiązanie formalne wyraża się w delegacji kompetencji przez organ wyższy organowi niższemu do wydania aktu prawnego określonej treści. Ich przeciwstawieniem są powiązania materialne charakteryzujące system statyczny, a opierające się na związkach treściowych, polegających na tym, że z treści określonej normy można wydedukować treść normy niższego rzędu. Takim jest system moralny, a przykładem powyższych powiązań może być norma „miłuj bliźniego swego”, z której wynika szereg norm: „,nie zabijaj”, „pomagaj” etc. System dynamiczny, czyli oparty na powiązaniach formalnych, charakteryzuje się tym, że normy prawne obowiązują nie ze względu

${ }_{52}$ RR2, s. 10-11; J. Wróblewski, Krytyka normatywistycznej..., s. 162.

${ }_{53}$ RR2, s. 11.

${ }^{54}$ J. Wróblewski, Krytyka normatywistycznej..., s. 123-124.

${ }^{55}$ HP II, s. XIV. 
na swoją treść, lecz ze względu na formę powstania. Kelsen zauważa, że następuje tu zlanie się stanu faktycznego oraz normy. Tym, co norma wyższego rzędu przedstawia jako stan faktyczny o charakterze prawotwórczym, jest normą z punktu widzenia tworzenia normy niższego rzędu. Nie dotyczy to jedynie początku i końca tego swoistego łańcucha, tj. normy podstawowej oraz aktu urzeczywistniającego normę o charakterze indywidualnym. Z tej tezy, jak trafnie zauważa Wróblewski, wynika, że byt nieustannie zmienia się w powinnośćs ${ }^{56}$, relacje zachodzące między nimi są dynamiczne i nie można mówić o całkowitym odseparowaniu jednego od drugiego. Ponadto, taka konstrukcja zaciera różnicę między stosowaniem prawa a jego tworzeniem. Dany akt prawny jest zarazem aktu stosowania, jak i tworzenia prawa (poza normą podstawową i normą indywidualną)

\subsubsection{Norma podstawowa}

Norma podstawowa jest jedną z ciekawszych konstrukcji czystej teorii prawa, a tym samym przedmiotem szerokiego zainteresowania doktryny. Raz pisze o niej w następujący sposób:

Ze wszystkich doktryn filozofii prawa teoria normy podstawowej Kelsena ściągnęła na siebie największą uwagę i najbardziej pobudziła wyobraźnię. Pozyskała sobie entuzjastycznych wyznawców oraz zapamiętałych przeciwników. Zarówno zwolennicy, jak i krytycy teorii w dużym stopniu ulegli niejasnej prezentacji Kelsena. Niejasność była poddawana krytyce i prowadziła do pojawienia się stwierdzeń, że cała teoria jest mitem; ale dostarczyła również admiratorom materiału w postaci dwuznaczności, które łatwo wymykały się krytyce ${ }^{57}$.

Na potrzeby podjętych tu rozważań wydaje się, że wystarczy ogólne omówienie tego pojęcia i nieco szersze ujęcie problemu normy podstawowej jako przesłanki argumentu transcendentalnego w rozdziale dotyczącym fazy klasycznej.

Jerzy Stelmach wskazuje na kilka znaczeń normy podstawowej. Nie wszystkie z nich zostały zastosowane przez Kelsena. Norma podstawowa może być rozumiana jako: (1) norma o największej, w sensie aksjologicznym, wartości, (2) norma pomyślana, (3) reguła uznania, (4) rodzaj prawniczego a priori lub przedrozumienia $^{58}$. Kelsen rozpatrywał pojęcie normy podstawowej tylko w dwóch pierwszych jej znaczeniach. Norma podstawowa, jako norma o największej wartości, odnosi się do systemu statycznego, ma raczej zastosowanie w przypadku norm moralnych. Inne normy obowiązują jako jej logiczne konsekwencje i zawierają w sobie nakaz jej przestrzegania ${ }^{59}$. Z punktu widzenia prawa, interesujące jest drugie rozu-

56 Ibidem, s. 170.

57 J. Raz, Autorytet prawa, tłum. P. Maciejko, Dom Wydawniczy ABC, Warszawa 2000, s. 122.

58 J. Stelmach, Norma podstawowa, „Studia z Filozofii Prawa”, Wydawnictwo UJ, Kraków 2001, s. 64.

59 Ibidem, s. 64. 
mienie normy podstawowej, jako normy pomyślanej, będącej elementem systemu dynamicznego ${ }^{60}$. Owa koncepcja pojawiła się dopiero w drugiej fazie i jest zarazem jedną z koniecznych form poznania prawnego, jak i próbą udzielenia odpowiedzi na pytanie, „dlaczego obowiązuje pierwsza konstytucja?"61 Ów problem jest konsekwencją metodologicznych założeń czystej teorii prawa, ponieważ ani wcześniejsi pozytywiści, ani zwolennicy teorii prawno-naturalnych nie mieli problemu z odpowiedzią na to pytanie. Pierwsi uzasadniali obowiązywanie pierwszej konstytucji odwołując się do faktów, drudzy, do porządku prawno-naturalnego.

Kelsen, odrzucając zarazem tezę o związku i tezę redukcyjną, musiał znaleźć trzecią drogę. Okazała się nią norma podstawowa. Kelsen wskazuje, że norma podstawowa konstytuuje obowiązywanie i ma charakter hipotetyczno-relatywny. Funkcjonuje jedynie w prawniczej świadomości i odnosi się do obowiązujących systemów prawa. Jest artykulacją warunków niezbędnych dla uporządkowania materiału prawnego ${ }^{62}$. Jej istota polega zatem na tym, że nie mogąc odwołać się do faktów i innego porządku normatywnego, a zarazem uznając obowiązywanie prawa, istnienie takiej normy trzeba założyćc ${ }^{6}$. Wróblewski zauważa, że mamy tu przełamanie dualizmu bytu i powinności, bowiem z faktów wyprowadza się treść normy podstawowej ${ }^{64}$. Kelsen broni tej niekonsekwencji, stwierdzając, że wprawdzie byt i powinność wzajemnie się wykluczają, ale pozostają ze sobą w związku treściowym. Oznaczałoby to, że istnieje możliwość wyboru pomiędzy kilkoma normami podstawowymi i należy wybrać tę, która gwarantuje prawu jego największą skuteczność. Zirk-Sadowski wskazuje w tym kontekście na podobieństwo między normą podstawową a apriorycznymi założeniami u Kanta ${ }^{65}$. Jest to trafne spostrzeżenie, bowiem takie ujęcie niezbędne jest Kelsenowi do wprowadzenia własnej wersji argumentu transcendentalnego, który zostanie przedstawiony w dalszej części rozważań.

Kelsen początkowo stał na stanowisku, że norma podstawowa ma charakter hipotetyczny, jednak w ostatniej fazie zmienił zdanie, przypisując jej fikcyjny (wbrew faktom) charakter. Jak zatem uzasadnić konieczność założenia takiej hipotezy, a nawet fikcji, nie narażając się na zarzut zignorowania postulatu brzytwy Ockhama? Kelsen stwierdza, że bez założenia obowiązywania normy podstawowej żaden akt ludzki nie mógłby zostać zinterpretowany jako, akt prawny. Norma podstawowa jest warunkiem poznania prawnego ${ }^{66}$. Interesującym zarzutem

60 Ibidem, s. 65.

${ }^{61}$ H. Kelsen, Die philosophischen Grundlagen der Naturrechtslehre und des Rechtspositivismus, [w:] H.R. Klecatsky, R. Marcic, H. Schambeck (Hrsg.), Die Wiener rechtstheoretische Schule, Franz Steiner Verlag, Stuttgart 2010, s. 236.

62 Ibidem, s. 235.

63 J. Stelmach, Norma..., s. 65.

64 J. Wróblewski, Krytyka normatywistycznej..., s. 180.

65 M. Zirk-Sadowski, Soft-Kelsenism..., s. 56.

66 H. Kelsen, Die philosophischen Grundlagen..., s. 236. 
wobec tej konstrukcji jest wskazany przez Wróblewskiego, który zauważa, że przy uwzględnieniu prawa międzynarodowego norma podstawowa staje się normą prawa międzynarodowego nakazującą uznanie skutecznego porządku prawnego. Jednak z uwagi na specyfikę prawa międzynarodowego takie rozumowanie mogłoby doprowadzić do wniosków nie do pogodzenia z normatywistycznymi tezami jak uznanie prawa natury. Wróblewski konkluduje, że norma podstawowa „daje blankietowe upoważnienie sile politycznej do wydawania dowolnych przepisów prawnych" ${ }^{\circ}$.

Konstrukcję normy podstawowej trafnie podsumowuje Raz, wyjaśniając, że Kelsen postuluje istnienie normy podstawowej ze względu na dwa aksjomaty jego filozofii. Po pierwsze, „dwa prawa, z których jedno bezpośrednio lub pośrednio autoryzuje stworzenie drugiego, należą koniecznie do tego samego systemu prawnego"68. Po drugie, ,wszystkie prawa systemu prawnego są pośrednio lub bezpośrednio autoryzowane przez jedno prawo" ${ }^{69}$. Te dwa aksjomaty tworzą razem zasadę tożsamości systemów prawnych i stanowią kryterium przynależności określonego prawa do systemu prawnego. Raz dodaje do nich trzeci aksjomat, którym jest dualizm bytu i powinności ${ }^{70}$. Wynika z tego, że norma podstawowa jest najwyższą regułą tworzenia prawa, założeniem każdego prawnika. Ma charakter formalny, nie determinuje treści innych norm w systemie prawa i odnosi się do konkretnego systemu prawa

Kelsen przypisuje normie podstawowej różne funkcje i definiuje ją na wiele sposobów. Dla zilustrowania bogactwa treści, którą niesie ze sobą pojęcie normy podstawowej, warto przytoczyć jej dziesięć sformułowań, które zrekonstruował Paulson. Norma podstawowa jest ${ }^{71}$ : (1) powszechnym źródłem jedności porządku zbudowanego przez normy, (2) kompetencją dla tworzenia norm niższego rzę$\mathrm{du}$, (3) kompetencją dla wykonania sankcji, (4) konstytucją w prawno-logicznym sensie, (5) normatywnym sensem powinności udzielonym normie, (6) warunkową definicją prawa jako norm przymusu, (7) ostatecznym powodem obowiązywania prawa, gdzie „obowiązywanie” (Geltung) jest rozumiane jako przynależność normy do określonego porządku, (8) ostatecznym powodem obowiązywania prawa, gdzie „obowiązywanie” jest rozumiane jako „mające moc wiążącą” (Verbindlichkeit), (9) środkiem do skonstruowania niesprzecznego ${ }^{72}$ systemu prawa, (10) gwarancją porządku prawnego, który ma sens.

${ }^{67}$ J. Wróblewski Krytyka normatywistycznej..., s. 178-184.

68 J. Raz, Autorytet..., s. 123.

${ }^{69}$ Ibidem, s. 124.

${ }^{70}$ Ibidem, s. 124-126.

${ }^{71}$ S.L. Paulson, Zwei radikale Objektivirungsprogramme in der Rechtslehre Hans Kelsens, [w:] S.L. Paulson, M. Stolleis (Hrsg.), Hans Kelsen Staatslehrer und Rechtstheoretiker des 20. Jahrhunderts, Mohr Siebeck, Tübingen 2005, s. 191.

72 Paulson pisze o ,zupełnym, to znaczy, niesprzecznym porządku prawnym”, czyli utożsamia takie cechy porządku prawnego jak niesprzeczność oraz zupełność (das eine einheitliche, d.h. widerspruchlose Rechtordnung; ibidem, s. 191). 
Jak z kolei wskazuje Wróblewski, norma podstawowa spełnia dwie funkcje: po pierwsze, podstawy obowiązywania wszystkich norm systemu (norma należy do porządku prawnego, ponieważ została stworzona zgodnie z normą podstawową); po drugie, gwarancji niesprzeczności systemu norm (dzięki niej alogiczny materiał prawny postrzegany jest jako pewna sensowna całość) ${ }^{73}$. Wróblewski zauważa, że jest to raczej postulat aniżeli obiektywna funkcja normy podstawowej i stawia trafne pytanie, do kogo ten postulat ma zostać skierowany. Materiał prawny postrzegany jako alogiczny wyklucza tezę, aby był to postulat skierowany do prawodawcy, ani do teoretyków prawa, skoro poruszają się oni jedynie w granicach istniejącego materiału prawnego ${ }^{74}$.

Sarkowicz i Stelmach wskazują, że logiczne wyjaśnienie normy podstawowej, która miałaby mieć charakter hipotetyczny lub fikcyjny, nie jest możliwe. Takiego uzasadnienia można dokonać jedynie, odwołując się do rozumu praktycznego $^{75}$. Podobnym zarzutem, który można podnieść wobec konstrukcji normy podstawowej, jest, jak wskazuje Hartney, jej opcjonalny charakter, wynikający z tego, że Kelsen stwierdza, że taką normę musi założyć ten, kto zajmuje się prawem. Rodzi się wówczas pytanie, czy nie oznacza to wyposażenia indywiduum w pewną dowolność w uznaniu lub nieuznaniu normy podstawowej? Inną wątpliwością, jaka się pojawia przy tym zagadnieniu, jest kwestia, kto zakłada istnienie normy podstawowej ${ }^{76}$. Analiza tych wątpliwości przekracza ramy podjętych tu rozważań.

\subsection{Podstawy metodologiczne}

Jeśli rozważy się wyłącznie samą strukturę prawa w kelsenowskim ujęciu, to będzie to obraz niekompletny. Tak jak doznania dostarczane przez zmysły w świecie wymagają interpretacji i uzasadnienia, tak samo opisanie struktury prawa (mniej lub bardziej trafne) nie uchyla pytania: „na jakiej postawie?”. Odpowiedzi dostarcza dopiero metodologia, którą zastosował Kelsen. Już w przedmowie do pierwszego wydania HP Kelsen stwierdza:

Metoda ma dla nauki podobne znaczenie jak ma technika w sztuce. [...] Strona metodologiczna jest tak dalece przeważająca, że omówienie i badanie wyłaniających się w granicach zakreślonych pracą niniejszą problemów nauki prawa państwowego ma miejsce nie tyle ze względu na problemy jako takie, ile raczej dla uzasadnienia słuszności przyjętych zasad metodologicznych ${ }^{77}$.

${ }_{73}$ J. Wróblewski, Krytyka normatywistycznej..., s. 174.

${ }^{74}$ Ibidem, s. 176.

${ }^{75}$ R. Sarkowicz, J. Stelmach, Filozofia prawa XIX i XX wieku, Wydawnictwo UJ, Kraków 1999, s. 48.

${ }^{76}$ M. Hartney, Introduction..., s. XVIII.

${ }^{77}$ HP I, t. 1, s. 10. 
Owa doniosłość zagadnień metodologicznych wynika przede wszystkim z tego, że nadrzędnym celem Kelsena było udzielenie odpowiedzi o warunki naukowości prawoznawstwa. W takiej sytuacji metodologia z konieczności jest jednym $\mathrm{z}$ istotniejszych zagadnień w teorii Kelsena. Dążąc do stworzenia czystej teorii prawa, wyszedł on z założenia, że nie da się stworzyć nauki prawa, dopóki nie „odseparuje” się go od elementów obcych, na przykład socjologicznych. Nie jest to jednak zadanie proste, często bowiem granice pewnego typu nauk, $w$ tym nauki prawa, pozostają ze sobą w styczności. Tym, co je różni, jest metoda badania $^{78}$. Normatywizm jest teorią odrzucającą pluralizm metodologiczny. Opiera się na kombinacji metody formalno-dogmatycznej z metodą normatywną oraz neokantowskiej tezie, że metoda poznania warunkuje przedmiot badania. Według Kelsena stosowanie wielu metod prowadzi tylko do zafałszowania obrazu, a odrębność prawoznawstwa od innych nauk może się bronić tylko pod warunkiem przyjęcia, że istnieje dla niego specyficzna, metoda ${ }^{79}$. Dla Kelsena osią wszelkich rozważań i podstawowym narzędziem jest dualizm bytu i powinności oraz przeciwstawienie formy i treści, które sprowadza się do twierdzenia, że w nauce prawa istotna jest forma, zaś treść norm pozbawiona jest znaczenia. W wywodach Kelsena wyraźne są również echa neokantyzmu (poza ostatnią fazą, w której Kelsen szeroko odwoływał się do filozofii analitycznej) oraz pozytywizmu prawniczego. $\mathrm{Z}$ uwagi na to, że zarówno neokantyzm, jak i filozofia analityczna są tłem charakterystycznym tylko dla określonych faz, zaś pozytywistyczne wpływy są widoczne w każdym okresie, w niniejszym rozdziale zostanie pokrótce omówiony ten ostatni kierunek myślowy, jako jedyny, który da się wyciągnąć poza nawias.

\subsubsection{Pozytywizm prawniczy i metoda formalno-dogmatyczna}

Trudno znaleźć jednolitą definicję tego jakże zróżnicowanego nurtu. Zirk-Sadowski dokonuje rozróżnienia na pozytywizm pierwotny i wyrafinowany. Pierwotny pozytywizm charakteryzuje się uproszczoną wizją prawa, w której duży nacisk jest położony na rozkaz suwerena, nieomal całkowicie pomijając aspekt uczestniczenia prawników w kulturze. Działalność sędziowska jest zinstrumentalizowana. Przeciwstawiany jest mu pozytywizm wyrafinowany, którego prominentnym przedstawicielem jest Hart z koncepcją wewnętrznego i zewnętrznego spojrzenia na prawo ${ }^{80}$. Teoria Kelsena zdecydowanie zalicza się do pierwszej grupy, jednak się w niej wyróżnia. To już nie jest pozytywizm naiwny, tylko taki, w którym zostaje podjęta próba stworzenia precyzyjnych narzędzi naukowego poznania prawa.

78 Ibidem.

79 J. Wróblewski, Egologiczna teoria prawa przeciw czystej teorii prawa, „Państwo i Prawo” 1959, nr 8-9, s. 300-301.

${ }^{80}$ M. Zirk-Sadowski, European Judicial Governance and Legal Philosophy, [w:] B. Wojciechowski, M. Zirk-Sadowski, M.J. Golecki (eds), Between Complexity..., s. 341-343. 
Aby udzielić odpowiedzi na pytanie, czym charakteryzuje się pozytywizm prawniczy, warto przytoczyć charakterystykę podaną przez H.L.A. Harta, który wskazywał, że charakterystyczne dla pozytywizmu są następujące twierdzenia:

(1) prawa są rozkazami ludzi;

(2) [...] nie istnieje żaden konieczny związek pomiędzy prawem i moralnością czy też prawem takim, jakie jest, i prawem takim, jakie być powinno;

(3) [...] analiza czy też badanie znaczeń pojęć prawnych jest czymś nadzwyczaj ważnym i musi być odróżnione (chociaż wcale nie koliduje z nimi) od badań historycznych, socjologicznych oraz krytycznej oceny prawa z punktu widzenia moralności, celów społecznych, funkcji etc;

(4) [...] system prawa jest „,zamkniętym systemem logicznym”, a poprawne decyzje w jego ramach mogą być wydedukowane z uprzednio ustalonych reguł prawnych przez wyłączne odwołanie się do logiki;

(5) [...] przekonania moralne nie mogą być dowodzone w taki sposób, jak stwierdzenia o faktach, tj. za pomocą racjonalnej argumentacji, doświadczenia lub dowodu ${ }^{81}$.

Jak widać, tylko część tez odnosi się do normatywizmu. Z pewnością są to tezy: druga, trzecia i piąta. Teza pierwsza w pewnym zakresie, w postaci twierdzenia, że norma prawna może przyjąć postać rozkazu, pojawia się u Kelsena $\mathrm{w}$ trzeciej i w czwartej fazie, natomiast teza czwarta zanika w okresie językowo-analitycznym. Kelsen recypuje charakterystyczną dla pozytywizmu metodę formalno-dogmatyczną, która opiera się na oderwaniu rozważań o prawie od kontekstu społecznego, etycznego itp. i bada formę normy prawnej oraz strukturalne powiązania systemu prawa. Jej zadaniem jest wyodrębnienie pojęć podstawowych dla prawoznawstwa, powtarzających się w każdym systemie prawa, pojęć niezmiennych. Są one traktowane bądź jako składowe elementy każdego systemu prawa, bądź jako konieczne warunki poznania prawnego. ten drugi sposób rozumienia jest charakterystyczny dla Kelsena ${ }^{82}$. Innymi słowy, zadaniem normatywizmu jest identyfikacja takich pojęć prawnych, których rola można nasuwać skojarzenie z arystotelesowską rolą formy, jako tej niezmiennej, dzięki której materia staje się ,czymś”.

Wróblewski trafnie wskazał, w jaki sposób Kelsen dokonał recepcji metody formalno-dogmatycznej, stwierdzając, że podstawowe pojęcia prawne, będące kategoriami poznania prawnego, to według Kelsena m.in.: obowiązek, prawo podmiotowe, podmiot, osoby w prawie, przymus, porządek prawny oraz przestępstwo $^{83}$. Każde z tych pojęć jest sprowadzane do wspólnego mianownika: normy prawnej, dzięki czemu mogą one sprawiać wrażenie pozbawionych wszelkich elementów zewnętrznych wobec prawa. Zabieg ten również thumaczy, dlaczego pojęcie normy prawnej, jej analiza, zajmuje centralne miejsce w czystej teorii prawa.

${ }^{81}$ H.L.A. Hart, Pojęcie prawa, thum. J. Woleński, Wydawnictwo Naukowe PWN, Warszawa 1998, s. 399.

82 J. Wróblewski, Krytyka normatywistycznej..., s. 187-188.

83 Ibidem, s. 192. 
Formalny charakter metody sprowadza się do tego, że Kelsen nie zastanawia się, jakie prawo powinno być bądź w jaki sposób miałoby powstać. Te elementy również zakłócają proces pełnego poznania prawa. Jak zauważa Wróblewski, formalizm Kelsenowi jest niezbędny, by „stworzyć aparaturę pojęć czystych" ${ }^{84}$. Wątpliwości, czy można stworzyć naukę bez treści, Kelsen rozwiewa, wskazując na geometrię, stwierdzając przy tym, że nauka prawa może być postrzegana jako geometria całego zjawiska, którym jest prawo ${ }^{85}$. Widać tu echa kantyzmu. Kant nie pyta, co się poznaje, lecz jak się poznaje ${ }^{86}$.

Metoda formalno-dogmatyczna zarówno w szerszym kontekście pozytywizmu prawniczego jak i u Kelsena jest popularnym obiektem krytyki. Jak jednak zauważa - krytyczny wobec Kelsena - Martyniak:

Krytykowanie czystej teorii prawa $\mathrm{z}$ powodu jej formalizmu, uważanie pojęć prawnych za bezwartościowe $\mathrm{z}$ tego powodu, że są pozbawione treści, byłoby tym samym, co odrzucanie pojęć geometrycznych, dlatego, że one określają tylko formę ciał, nic nie mówiąc o materii, z której je zrobiono ${ }^{87}$.

Owo spostrzeżenie wydaje się być słuszne. Naukowy opis zawsze wymaga pewnego uogólnienia. Im większa jest uniwersalność naukowych tez (przy założeniu, że nie są one banalne), tym wyższa wydaje się wartość naukowego opisu. W końcu ideałem dzisiejszej nauki jest stworzenie teorii wszystkiego.

\subsubsection{Metoda normatywna}

Jak wskazuje Wróblewski, Kelsen modyfikuje założenia metody formalno-dogmatycznej, jako niewystarczającej dla normatywizmu, poprzez wprowadzenie w swoje rozważania tezy normatywnej ${ }^{88}$. Postulat czystości nauk prawnych doprowadził Kelsena do zakwestionowania popularnych wówczas metod psychologicznych, socjologicznych i historycznych. Kelsen krytykuje metodę psychologiczną, wskazując, że o ile norma moralna może się wiązać z indywidualnym podejściem do zjawisk, $w$ których norma ta jest ściśle powiązana $\mathrm{z}$ określonym stanem, czy przeżyciem psychicznym jednostki, o tyle w przypadku prawa i normy prawnej takie ujecie prowadziłoby do absurdu, z uwagi na to, że norma ta osadzona jest $\mathrm{w}$ świecie powinności ${ }^{89}$. Zdaniem Kelsena, wszelkie metody skuteczne w badaniach zjawisk osadzonych w rzeczywistości dla poznania prawa zawodzą. Prawo jako takie musi być badane metodami adekwatnymi dla świata, w którym

\footnotetext{
${ }^{84}$ Ibidem, s. 69.

${ }^{85}$ HP I, t. 1, s. 141-142.

86 Ibidem, s. 67.

${ }^{87}$ C. Martyniak, Moc obowiązujaca obowiazujaca prawa a teoria Kelsena, [w:] C. Martyniak, Dzieła, red. ks. R. Charzyński, M. Wójcik, Wydawnictwo KUL, Lublin 2006, s. 200.

${ }^{88}$ J. Wróblewski, Krytyka normatywistycznej..., s. 20-21, 57.

${ }^{89}$ HP I, t. 1, s. 88.
} 
istnieje, czyli świata powinności. Stąd konieczność poszukiwania innej metody aniżeli opartej na związku przyczynowo-skutkowym. Należy podkreślić, że Kelsen wprawdzie odrzuca w swych rozważaniach wszelkie wątki socjologiczne czy historyczne, jednak twierdzi, że:

trudno zabraniać prawnikowi badań socjologicznych, psychologicznych czy historycznych. Przeciwnie, są one potrzebne, lecz prawnik nie może zapominać, że badając rzecz socjologicznie, psychologicznie, czy historycznie wchodzi na zupełnie inną drogę, niż ta, która prowadzi do ścisłe prawniczego poznania i nie może wyników swych eksplikatywnych badań używać do konstrukcji pojęć normatywnych. O ile ze względu na szczególna naturę moralności możliwa jest psychologiczna lub socjologiczna etyka - o tyle w nauce prawa jest to metodologicznie niedopuszczalne. Nauka prawa przestałaby być wówczas sobą i stałaby się w najlepszym razie psychologią, lub socjologią prawa, a raczej życia prawnego ${ }^{90}$.

Prawo można badać metodami właściwymi dla socjologii czy historii, ale nie przyniosą one odpowiedzi na fundamentalne pytania dotyczące jego istoty. I tak psychologia, według Kelsena, bada oddziaływanie norm na sferę ludzkich zachowań i ich motywację, zaś socjologia ujmuje problem szerzej, widząc w prawie władzę mającą wpływ na społeczeństwo, jednak kwestie te, choć niewątpliwie z prawem związane, nie przesądzają o jego cechach konstytutywnych. Ujmowanie prawa od strony historycznej, psychologicznej czy socjologicznej jest jak najbardziej poprawne z punktu widzenia socjologii prawa czy psychologii prawa, ale nie w przypadku teorii prawa, mającej za zadanie rozstrzygnąć kwestie, czym prawo jest ${ }^{91}$ Powodem, dla którego Kelsen tak stanowczo opowiada się za czystością metody, jest niechęć do używania prawa jako narzędzia usprawiedliwiającego różnego rodzaju ideologie. Jeśli będzie się badać prawo takim, jakie ono jest $\mathrm{w}$ sferze powinności, to uniknie się niebezpieczeństwa zniekształcenia jego obrazu przez ideologię. Kelsen twierdzi, że istnieje ogromna różnica pomiędzy szukaniem prawdy a interesami politycznymi czy ekonomicznymi, i jednego pogodzić z drugim się nie da. Trzeba więc wyraźnie odseparować te dwie sfery92.

Metoda normatywna jest właściwa do badań świata powinności. Według Wróblewskiego, opiera się ona na tezie o istnieniu ,idealnej rzeczywistości powinności i wartości” ${ }^{93}$. Stelmach w tym kontekście pisze o „normatywnym antynaturalizmie", sprowadzającym się do przeciwstawienia metody poznania norm prawnych i metod rządzących poznaniem empirycznym czy logicznym ${ }^{94}$. To interesujące spostrzeżenie, szczególnie w kontekście rozważań na temat scjentyzmu Kelsena. Potwierdza ono wniosek, że Kelsen obrał podobny do scjentystów cel, jednak odrzucił ich metodę jako niekompatybilną z przedmiotem badania, czyli normami.

90 Ibidem, s. 86.

${ }^{91}$ Ibidem, s. 85-86.

92 W. Ebenstein, The Pure Theory of Law: Demythologizing Legal Thought, ,California Law Review" 1971, vol. 59, s. 623.

93 Ibidem, s. 39.

94 J. Stelmach, Metody prawnicze, Zakamycze, Kraków 2004, s. 29. 
Natomiast Wróblewski twierdzi, że Kelsen, zawężając zastosowanie metody normatywnej jedynie do poznania prawa, wykluczając z zakresu jej badań wszelkie inne zjawiska pozanormatywne należące do sfery przyczynowej, popełnia błąd, polegający „na mieszaniu przedmiotu badania z samym badaniem tego przedmiotu”. $\mathrm{Z}$ tego punktu widzenia, ,badając zdania można wypowiadać tylko zdania, badając zaś oceny można wypowiadać tylko oceny", oraz że Kelsen, postulując oddzielenie nauki prawa od prawa, nie zauważył tkwiącej tu sprzeczności ${ }^{95}$. Jest to niezwykle ciekawy zarzut. Czy jednak słuszny? Moim zdaniem, Wróblewski przedstawia tu dwa zarzuty. Jeden z nich dotyczy uzasadnienia konieczności zastosowania metody normatywnej podczas badania norm prawnych, drugi natomiast samej metody.

Jeśli chodzi o konieczność badania norm za pomocą metody normatywnej, wydaje się, że Kelsen dość wyczerpująco uzasadnił to w pracy habilitacyjnej, która w dużej części poświęcona jest zwalczaniu poglądu stwierdzającego, że norma prawna jest faktem i w taki sposób powinna być badana. Teza Kelsena jest następująca: norma prawna nie jest faktem, więc nie można traktować jej jako faktu i badać w podobny sposób jak bada się okrzemki. W badaniach nad przyrodą duże znaczenie mają powiązania przyczynowo-skutkowe (na przykład, jeśli urwiemy jaszczurce ogon, to on się zregeneruje). Fenomenem norm jest to, że w zdaniach owe normy wyrażających nie ma powiązań przyczynowo-skutkowych, choć ich struktura jest podobna i przypomina strukturę zdań oznajmujących. Zamiast powiązań przyczynowo-skutkowych mamy do czynienia z powiązaniem o charakterze normatywnym, czyli zarachowaniem. Jest to konsekwencja stwierdzenia, że normy opisując nie byt, ale powinność są zdaniami powinnościowymi. Metoda normatywna postuluje uwzględnienie owego stanu rzeczy i niemieszania niezwykle bogatego świata faktycznego do badań nad normami. Chodzi o niewykraczanie poza pewien zakres zjawisk, w tym przypadku normatywnych. Postulat Kelsena sprowadza się do stwierdzenia, że jeśli chce się badać normy, to trzeba czynić to za pomocą odpowiedniej siatki pojęciowej. Gdy bada się okrzemki, nie wrzuca się ich do akceleratora cząstek, lecz ogląda pod mikroskopem, zaś gdy bada się normy prawne, nie czyni się tego za pomocą języka socjologii czy przyrody.

Odnośnie do drugiego zarzutu, wydaje się on nie do końca zrozumiały. Kelsen w swoich badaniach nad normami nie posługuje się językiem charakterystycznym dla samych norm, o strukturze warunkowej. Stosuje siatkę pojęciową charakterystyczną dla norm prawnych i prawa nie wykraczając poza jej granice.

\subsubsection{Dualizm bytu i powinności}

Refleks rozróżnienia między światem przyrody a światem myśli można odnaleźć w koncepcji Kelsena dualizmu bytu i powinności. Jest to teza, na której opiera się cała jego teoria, stąd niezwykle ważne jest zrozumienie, na czym po-

${ }_{95}$ Ibidem, s. 44-45, przyp. 19. 
lega. W niniejszej części zostaną przedstawione ogólne założenia odnoszące się do dualizmu bytu i powinności. Szczegółowe rozważania zostaną zawarte w dalszych rozdziałach.

Na wstępie warto rozważyć, w jaki sposób należy rozumieć ten podział w jego najogólniejszym znaczeniu. Wydaje się, że powinność można wiązać się z pewną oceną porządku świata materialnego, która często przybiera formę negatywną. Dokonywanie oceny zawsze należy do zjawisk kulturowych, będąc wręcz jedną z przyczyn ich powstania. Proces ten mógłby zostać przedstawiony w następujący sposób: najpierw zastaje się określona rzeczywistość, jednak nie jest ona przyjmowana w sposób bierny. Zawsze istnieją w niej elementy niedoskonałe. Drugim etapem jest identyfikacja problemu: „w danej rzeczywistości zjawisko A stanowi problem”. Etap trzeci to przejście z bytu do powinności: „,skoro zjawisko A stanowi problem, to powinno się je zastąpić pożądanym zjawiskiem B. Jak zatem powinno wyglądać zjawisko B? Etap kolejny to zdefiniowanie zjawiska B w świecie powinności: „B powinno wyglądać x” - można tu mówić o zdefiniowaniu celu bądź o pewnej wizji. Kolejne kroki to już „mapa drogowa”, w jaki sposób z punktu A znaleźć się w punkcie B - obejmują strategie, taktykę i poziom operacyjny. W rezultacie następuje powrót do sfery bytu i zamiana zjawiska A na zjawisko B. Istniejące początkowo wyłącznie w sferze powinności B teraz należy już do sfery bytu. Powyższy schemat może powtarzać się w nieskończoność. Człowiek zastaje określoną rzeczywistość, którą zmienia i kształtuje. Jednocześnie, sam się zmienia pod wpływem rzeczywistości. Jest to zatem zmiana wzajemna, dynamiczna, dokonująca się nieustannie. Czy jednak ten schemat dobrze odzwierciedla to, co Kelsen miał na myśli tworząc swoją teorię? Kelsen prawdopodobnie odpowiedziałby na to pytanie przecząco, aczkolwiek miał świadomość istnienia takiego schematu ${ }^{96}$. Taka odpowiedź wynikałaby właśnie z samej tezy o dualizmie bytu

${ }^{96}$ Rozważania te są Kelsenowi niezbędne, aby wyjaśnić, czym jest wola państwa, kolejne kluczowe pojęcie jego teorii (a takiej postaci zaprezentowane przez Kelsena w pierwszej fazie). Punktem wyjścia rozważań czyni Kelsen nawiązanie do historycznego procesu transformacji sposobu tworzenia prawa, od zwyczaju do stanowienia. Kelsen zauważa, że historycznie, gdy istniały pierwotne stosunki społeczne, prawo było postrzegane, jako wola nadprzyrodzonej siły, wola boża. Podobny charakter posiadają koncepcje prawa natury głoszące, że prawo przedmiotowe to system praw podmiotowych, które są wrodzone każdemu człowiekowi. Oba stanowiska zakładają, że prawo jest zjawiskiem odrębnym od państwa, zaś rolą państwa jest ochrona tych praw. Gdy zaczęto odchodzić od prawa zwyczajowego na rzecz prawa stanowionego, przewagę zaczęła zdobywać koncepcja, że prawo przedmiotowe jest wolą państwa. Wynikało to $\mathrm{z}$ faktu, że treść normy nie wynikała $\mathrm{z}$ istniejących w społeczeństwie zwyczajów. To miejsce zajęła wola państwa, które decydowało, które normy są normami prawnymi. Skoro prawo jest wolą państwa, to warto wyjaśnić, co Kelsen miał przez to na myśli. Przede wszystkim, zaznacza Kelsen, „porządek prawny państwa stanowi jedynie założenie tego, co ma być za prawo uważane". Wynika to z charakteru organu państwowego, który może być określony dzięki jego działalności państwowej (a nie działalność państwowa z charakteru organu państwowego). Stwierdzenie, że porządek prawny jest wolą państwa, oznacza według Kelsena, że państwo jest „dzierżycielem tego porządku, którego treść stwarza proces społeczny [...] Każda norma prawna musi zawierać w sobie wolę państwa, zatem nie należy 
i powinności i brzmiałaby zapewne następująco: ten opis jest opisem pewnych procesów psychicznych. Te jako należące do sfery faktów nie są relewantne dla nauki prawa. Nawet jeśli taki opis jest prawdziwy w sferze faktów, to błędem byłoby rozpatrywanie go na płaszczyźnie powinności. Jak więc Kelsen definiuje powinność? Wydaje się, że Kelsen raczej pojmuje ją jako pojęcie aksjomatyczne.

Jak wskazuje Klug, przeciwko tezie o dualizmie bytu i powinności wysuwane są następujące argumenty ${ }^{97}$ : (1) naturalno-prawny - normy prawne wywodzą się z natury rzeczy, (2) fenomenologiczny - zawartość norm jest zdeterminowana przez istotę rzeczy, (3) ontologiczny - prawodawca jest powiązany ontologicznie poprzez wydanie normy ${ }^{98}$, (4) praktyczności - w zdaniach prawnych powinnościowych nie można żądać niemożliwego, (5) teleologiczny - z celów prawa wynika powiązanie z możliwym środkiem ich realizacji, (6) ekonomiczny - prawo musi uwzględniać poszczególne interesy, (7) aksjologiczny - prawo musi respektować ponadczasowe wartości, (8) historyczny - prawodawca musi uwzględniać tenden-

pytać: „kto jest twórcą prawa?”, lecz: „kto jest dzierżycielem porządku prawnego?” Według Kelsena twórcą prawa jest zawsze społeczeństwo. Skoro wola państwa jest jednym z centralnych pojęć omawianych teorii, Kelsen uznaje konieczność przeprowadzenia analizy pojęcia woli. Odwołuje się przy tym do psychologii. I właśnie przy tej analizie powołuje się na przytoczony powyżej schemat. Za wolę w psychologicznym tego słowa znaczeniu uważa Kelsen pewne zdarzenie lub stan, zdolne do zaspokojenia danej potrzeby $\mathrm{z}$ własną działalnością, jako środkiem do tego prowadzącym. Jednym z elementów składających się na pojęcie woli jest chęć będąca aktem świadomości, przy pomocy, którego ma być spowodowana zmiana w istniejącym stanie rzeczy lub treści świadomości. Jak wskazuje zatem Kelsen, punktem wyjścia, jest poczucie niezadowolenia lub braku (pkt 1 i 2 schematu), które łączy się z chęcią usunięcia tego stanu. Następnie, następuje uświadomienie sobie środka do usunięcia niezadowolenia (pkt 5 schematu). Treścią woli jest treść uświadomienia stanu niezadowolenia, zawierającego środki dążenia, czyli drogi realizacji celu. Dobranie środków służących zrealizowaniu woli, umożliwia istnienie powiązań przyczynowo-skutkowych. Należy zwrócić uwagę, że schemat dotyczy pojęcia powinności, natomiast Kelsen ten sam proces umieścił w kategoriach woli. Zabieg ten pozwolił mu na utrzymanie tezy o dualizmie bytu i powinności. Kontynuując swoje wywody, Kelsen zwraca uwagę na konieczność rozróżnienia pojęcia woli od życzenia. Wola łączy się z możliwością zaspokojenia chęci wywołania danego stanu rzeczy poprzez własne działanie. W procesie życzenia sobie czegoś brakuje tego elementu. Na przykład można sobie życzyć, by była piękna pogoda, podczas gdy nie można mieć takiej woli. Jednak, jak dalej zaznacza Kelsen, wola w psychologicznym znaczeniu, a wola w znaczeniu prawnym, to dwa różne pojęcia. W rozumieniu prawnym, pozbawiona jest znaczenia świadomość skutku, bowiem w prawie istotne jest powiązanie skutku (zaszłości zewnętrznej) z podmiotem, zaś ta nie może być postrzegana jako treścią woli w znaczeniu psychologicznym (HP I, t. 1, s. 147-162).

${ }_{97}$ U. Klug, Die Reine Rechtslehre von Hans Kelsen und die formallogische Rechtfertigung der Kritik an dem Pseudoschluss von Sein auf das Sollen, [w:] S. Engel (ed.), Law State and International Legal Order, Essays in Honor of Hans Kelsen, The University of Tennessee Press, Knoxville 1964, s. 155.

${ }_{98}$ Owo stwierdzenie jest wieloznaczne. Klug wskazuje, że można je zinterpretować na kilka sposobów: po pierwsze, że prawodawca jest ograniczony przez fakty wynikające z praw przyrody; po drugie, nie da się dowolnie kształtować treści używanych pojęć (co raczej jest kwestią definicji, a nie dualizmu bytu i powinności); po trzecie, zdania pojęciowe są zrekonstruowane z pojęć ontologicznych (ibidem, s. 163). 
cje rozwojowe $e^{99}$, (9) antropologiczno-psychologiczny - prawo nie może występować przeciwko ludzkim potrzebom i instynktom, (10) socjologiczny - prawo jest zależne od okoliczności społecznych. Owe argumenty dotyczą dualizmu bytu i powinności rozpatrywanego na wielu płaszczyznach. W większości są one jedynie dowodem na to, że między bytem i powinnością istnieją rożnego rodzaju „mosty”, z których tezy 1-3 dotyczą filozoficznych założeń, natomiast pozostałe to zbiór praktycznych postulatów dotyczących treści prawa. Nie wystarczy zatem samo postawienie tezy, o istnieniu dwóch rozdzielonych światów - świata bytu i świata powinności. Należy ją skonkretyzować, aby uniknąć nieporozumień.

Historycznie na istnienie dwóch porządków: bytu i powinności zwrócił uwagę Hume, formułując swoje słynne twierdzenie, że z tego, co jest nie, da się wyprowadzić tego, co być powinno. Owa teza zacznie nabierać znaczenia w trzeciej fazie Jednak jest to tylko jeden wymiar problemu. Dualizm bytu i powinności to coś więcej aniżeli logiczny wątek. Jak wskazuje Wróblewski, w teorii Kelsena to przeciwstawienie pełni następujące funkcje: po pierwsze, za jego pomocą Kelsen krytykuje pozytywizm prawniczy za tezę redukcyjną i tezę o roli, jaką ma pełnić logika w podejmowaniu decyzji prawnych; po drugie, Kelsen stosuje je przeciwko koncepcjom prawno-naturalnym wywodzącym normy z natury człowieka (czyli faktów); po trzecie, jest to dla Kelsena podstawowe narzędzie metodologiczne ${ }^{100}$.

$\mathrm{Z}$ punktu widzenia poruszanych przeze mnie zagadnień, ważnymi aspektami, w których można rozważać dualizm bytu i powinności, tak jak rozumiał ów dualizm Kelsen, są ${ }^{101}$ : (1) płaszczyzna logiczna, (2) płaszczyzna ontologiczna, (3) płaszczyzna epistemologiczna, charakterystyczna dla drugiej fazy, (4) płaszczyzna językowa, która pojawia się w ostatniej fazie. W niniejszym rozdziale szerzej zostaną omówione dwie pierwsze płaszczyzny, jako charakterystyczne dla całej czystej teorii prawa, pozostałe natomiast szczegółowo zostaną omówione w odpowiednich dla nich rozdziałach.

\subsubsection{Dualizm bytu i powinności na płaszczyźnie logicznej}

Jak już wspomniałam, o konsekwencjach dualizmu bytu i powinności na płaszczyźnie logicznej, najczęściej mówi się w kontekście tego, co zauważył Hume (tzw. gilotyna Hume’a), czyli, że ze zdań oznajmujących, będącymi zdaniami w sensie logicznym, nie można logicznie wywnioskować zdań powin-

${ }^{99}$ Odnośnie do tez 5-8 Klug argumentuje, że w tym wypadku powiązanie bytu i powinności $\mathrm{w}$ tej przesłance poprzedzone jest i tak normatywnym wyborem celu (ibidem, s. 166).

100 J. Wróblewski, The Is - Ought Dichotomy, „Revue Internationale de Philosophie” 1981, vol. 138, s. 509.

${ }_{101}$ J. Wróblewski, Krytyka normatywistycznej..., s. 36-54; por. V. Kanpp, Logische und ontologische Aspekte von Sein und Sollen (Gibt es ein Sollen des Seins und ein Sein des Sollens?), [w:] Die Normative Rechttheorie im Kontext der Rechtswissenschaft, Masarykova Univerzita v Brnie, Brno 1991, s. 59; R. Sarkowicz, J. Stelmach, Filozofia prawa..., s. 46. 
nościowych. Dla Kelsena jest to punkt wyjścia, dzięki któremu może rozwinąć swoją teorię w różnych kierunkach - ontologicznym, epistemologicznym, językowym. W filozofii prawa, owo zagadnienie ma wyjątkowo doniosłe znaczenie dla odpowiedzi na pytanie, czy możliwe jest zastosowanie logiki do norm. Pod tym względem nastąpiła silna polaryzacja zwolenników i przeciwników owej tezy. Nie brak do dziś myślicieli, próbujących podważyć twierdzenie Hume’a. Kontrprzykładów wobec tezy Hume'a starali się dostarczyć tacy myśliciele, jak John R. Searle i Max Black ${ }^{102}$. Przykład Searle’a jest następujący:

1. A obiecuje czynić $p$

2. Poprzez obietnicę czynienia $p$ A ustanowił wobec siebie zobowiązanie czynienia $p$

3. A powinien czynić $p^{103}$.

Searle wskazuje, że zdanie powinnościowe może zostać wywiedzione ze zdania o fakcie, zatem istnieje „most” pomiędzy bytem i powinnością. Niedługo po Searlu, na łamach tego samego czasopisma, swój przykład zaprezentował Black. Brzmi on następująco:

A i B grają w szachy. A chce wykonać ruch, który będzie szach matem wobec przeciwnika. Dopóki jednak nie wykona określonego ruchu, nie może tego zrobić. Zatem powinien zrobić ten ruch $^{104}$.

Georg von Wright zauważa, że jeśli nawet powinność można wyprowadzić ze zdania o fakcie, nie oznacza to wcale, że konkluzja normatywna może być wprowadzona z przesłanki zawierającej fakt, ponieważ może istnieć możliwość, że zdania powinnościowe tak naprawdę opisują fakty i vice versa ${ }^{105}$. Wiele tu zależy od interpretacji. Von Wright zaznacza, że w jakimś sensie dualizm bytu i powinności jest rozróżnieniem na to, co deskryptywne i preskryptywne. W rezultacie właściwie postawione pytanie brzmi: w jaki sposób, to co preskryptywne może wynikać (następować) z tego, co deskryptywne i czy możliwe jest wynikanie tego, co deskryptywne $\mathrm{z}$ tego co preskryptywne ${ }^{106} \mathrm{i}$ czy to co preskryptyw-

102 G.H. von Wright, Is and Ought, [w:] S.L. Paulson, B. Litschewski-Paulson (eds), Normativity and Norms, Clarendon Press, Oxford 1998, s. 368.

103 J.R. Searle, How to Derive Ought from Is?, „The Philosophical Review” 1964, vol. 73, no. 1 , s. 44.

${ }^{104}$ M. Black, The Gap Between Is and Should, „The Philosophical Review” 1964, vol. 73, no. 2 , s. $165-181$.

${ }^{105}$ Na przykład, art. 415 k.c.: „,kto z winy swej wyrządził drugiemu szkodę, zobowiązany jest do jej naprawienia" - mimo że owej normie nadano brzmienie zdania oznajmującego, to nie opisuje ona rzeczywistości, jej funkcja jest normatywna.

106 Według niektórych dowodem na możliwość owego wynikania jest kantowska zasada, że powinność implikuje możność (powinieneś, więc możesz). Według von Wrighta jednak mamy tu do czynienia jedynie z ,afirmacją zasadności określonego rozkazu” (G.H. von Wright, Is and..., s. 372). 
ne może wynikać z jakiejś innego opisu? Według Von Wrighta odpowiedź na te trzy pytania musi być przecząca ze względu na to, że logiczne wynikanie zawiera określoną ilość kombinacji, które mogą dać zdanie prawdziwe. Jeśli z A wynika B, to albo A jest fałszywe, albo B prawdziwe. Skoro zdania preskryptywne nie są ani prawdziwe, ani fałszywe, to nie mogą występować w roli przesłanek, czy też wniosku w wynikaniu logicznym ${ }^{107}$. Wracając do argumentu Searle'a, można postawić pytanie, czy przykład przez niego podany nie jest dedukowaniem normy z faktu. Von Wright udziela odpowiedzi przeczącej. Według niego, Searle nie wykazał, że powinność może zostać wyprowadzona z, a jedynie może być wyprowadzona $\mathrm{z}$ kombinacji bytu $\mathrm{z}$ inną powinnością, bowiem istnieje dodatkowa norma dotycząca dotrzymywania przyrzeczeń. Searle zresztą w swoim późniejszym artykule sam zwraca na to uwagę w odniesieniu do ocen podając jako przykład zdanie o fakcie „Jan skłamał” i ocenę „John zrobił coś złego”. Searle twierdzi, że ze zdania o fakcie możliwe jest wyprowadzenie takiej oceny jedynie wtedy, gdy doda się twierdzenie „nie wolno kłamać” 108 .

Ponadto, według von Wrighta istnieją wątpliwości, czy jedna z przesłanek była normatywna, czy może raczej było to zdanie stwierdzające, że istnieje norma dotycząca dotrzymywania obietnic. Wątpliwe jest nawet, czy konkluzja posiadała normatywny charakter. Jeśli nie, to przykład Searle'a w ogóle nie poruszałby problemu bytu i powinności ${ }^{109}$. Abstrahując jednak od tego zagadnienia, von Wright, zwraca uwagę na wniosek z przykładu Searle’a sprowadzający się do schematu:

A powinien czynić $p$,

twierdząc, że bynajmniej nie mamy tu do czynienia z normą, tylko z innym rodzajem powinności, zwanej powinnością techniczną, które należy rozumieć jako „o ile coś nie zostanie dokonane (to co powinno), co innego również nie będzie mieć miejsca" ${ }^{110}$. Na przykład, ,jeśli nie zapłacę za X, nie nabędę X na własność”. Techniczna powinność może się wyrażać nie tylko przez modalność „powinien”, ale i „musi” i jest relacją między środkiem a celem. Von Wright zwraca uwagę na jej podobieństwo do imperatywu hipotetycznego Kanta. Powinność techniczną należy odróżnić od powinności normatywnej, która jest zobowiązaniem nałożonym przez normę. To samo można odnieść do przykładu przedstawionego przez Blacka.

Ciekawa wydaje się odpowiedź Searle’a. Na początku zwraca on uwagę, że powinność jest powiązana z powodami uczynienia czegoś lub powodami

107 G.H. von Wright, Is and..., s. 371.

108 J.R. Searle, Fact and Value, ,Is" and ,Ought”, and Reasons for Action, [w:] G.O. Mazur (ed.), Twenty-Five Year Commemoration to the life of Hans Kelsen, Semenko Foundation, New York 1999, s. 21.

109 G.H. von Wright, Is and..., s. 376.

${ }_{110}$ Ibidem, s. 377. 
wierzenia w coś, a stwierdzenie, że ktoś coś powinien uczynić jest równoznaczne ze stwierdzeniem, że istnieją określone powody, by to uczynił ${ }^{111}$. Searle powołuje się tu na prosty przykład zwierzęcia widzącego przed sobą drzewo. Według Searle'a mamy tu do czynienia ze zdaniem

zwierzę widzi przed sobą drzewo,

z którego da się wyprowadzić zdanie powinnościowe:

zwierzę powinno wierzyć, że przed nim jest drzewo.

Searle zwraca uwagę, że te dwa stwierdzenia wydają się wymagać dodatkowej przesłanki:

prawdą jest, że przed zwierzęciem jest drzewo,

ponieważ w grę mogą wchodzić halucynacje. Jednak według Searle'a nie zmienia to faktu, że jeśli doznaje się pewnego wrażenia, to racjonalność wymaga tego, że powinno się w nie wierzyć. Podobnie jeśli żywi się dwa sprzeczne przekonania, to ma powód, by porzucić jedno z nich, czyli powinno porzucić jedno z nich ${ }^{112}$. Wydaje się jednak, że ta interpretacja jest nazbyt psychologiczna. W ten sposób da się wyprowadzić powinność z bytu, ale na gruncie psychologii zakładającej subiektywizm, a nie logiki rządzącej się obiektywnymi prawami.

Inaczej problem próbuje rozwiązwać Fitzsche, wskazując na „mosty” między bytem i powinnością na płaszczyźnie logicznej. Należą do nich rozszerzenie dysjunkcyjne i modus tollens. Rozszerzenie dysjunkcyjne oznacza, iż jeżeli zdanie $p$ jest prawdziwe, to również jego połączenie z normatywnym twierdzeniem $q$ poprzez alternatywę „lub” jest prawdą. Oznacza to, że kiedy $p$ jest prawdą, to również $p$ lub $q$ jest prawdą. To zdanie wskazuje jedynie na związek $p$ do $q$, nie mówi zaś nic o obowiązywaniu $q$. Zdanie $p$ lub $q$ jest prawdziwe, jeśli co najmniej jedno ze zdań jest prawdziwe. Jednak w przypadku, gdy $q$ odnosi się do rzeczywistości prawnej, to tak naprawdę można stwierdzić wyłącznie prawdziwość lub nieprawdziwość $p$. O wartości $q$ nic nie można powiedzieć. Zatem, uznanie, iż niniejsza zależność jest zasadą łączącą sein i sollen, jest wątpliwe ${ }^{113}$. Z kolei modus tollens w odniesieniu do rzeczywistości prawnej wyraża się w następującym wnioskowaniu:

jeśli $p$ to $q$

$q$ nie powinno (być)

to nie (ma) $p$.

111 J.R. Searle, Fact and Value..., s. 23.

112 Ibidem, s. 27-30.

113 T. Fritzsche, Die Reine Rechtslehre..., s. 52. 
Jako zasada łącząca byt i powinność, według Fitzschego, niniejsze powiązanie może zostać zastosowane w przypadku konfliktu norm ${ }^{114}$. Wydaje się jednak, że przesłanka wyrażona w następniku implikacji, nie może zostać uznana za posiadającą wartość logiczną. Zatem i modus tollens jest konstrukcją co najmniej problematyczną w stosunku do norm Podsumowując za Wróblewskim, z wypowiedzi orzekających o przyrodzie nie można wnioskować logicznie wypowiedzi będących ocenami bądź normami, o ile bowiem te pierwsze mogą podlegać kryterium prawdy lub fałszu, to o tych drugich można jedynie powiedzieć, że są mniej lub bardziej słuszne ${ }^{115}$. Z punktu widzenia metody formalno-dogmatycznej, między bytem i powinnością nie ma zatem punktów stycznych. Przyczyna konkretnej powinności leży w innej powinności, tak jak przyczyna konkretnego stanu faktycznego leży w innym stanie faktycznym ${ }^{116}$.

\subsubsection{Dualizm bytu i powinności na płaszczyźnie ontologicznej}

Pierwotnie Kelsen rozpatrywał byt i powinność głównie na płaszczyźnie ontologicznej. Z biegiem czasu traci ona na znaczeniu, by pod koniec nieomal zupełnie zaniknąć. Jednak echa tak ujętego bytu i powinności można znaleźć nawet w ostatniej fazie, mimo że sprawiają one raczej wrażenie reliktu.

Dualizm na płaszczyźnie ontologicznej może zostać podzielony na: prawno- naturalny, pozytywistyczny, socjologiczny ${ }^{117}$. Z oczywistych powodów kelsenowski dualizm bytu i powinności ma charakter pozytywistyczny. Dotyczy on istnienia dwóch rodzajów rzeczywistości: empirycznej określonej czasowo i przestrzennie poznawanej za pomocą zmysłów oraz pozazmysłowej poznawanej rozumem, w której istnieją przedmioty idealne w postaci norm ${ }^{118}$. Kelsen za Georgiem Simmelem ${ }^{119}$ identyfikuje przeciwstawienie bytu i powinności z przeciwstawieniem przyrody i społeczeństwa, gdzie prawo należy do tej drugiej sfery ${ }^{120}$. Jednak ten dualizm nie jest u Kelsena niczym uzasadniony, ponieważ powinność ma charakter aprioryczny ${ }^{121}$. Autor czystej teorii prawa rozpoczyna swój wywód od rozróżnienia przyrody (natury) od prawa (normy prawnej). Zadaniem praw natury jest wyjaśnienie rzeczywistości, podczas gdy inne nauki (w tym nauki prawne) zajmują się tworzeniem reguł i postulatów, czyli ustanawiają powinności. Te dwa sposoby patrzenia na świat implikują dwa rodzaje sądów: o bycie („tak jest”) i po-

114 Ibidem, s. 52-53.

115 J. Wróblewski, Krytyka normatywistycznej..., s. 38.

116 Ibidem, s. 52-53.

117 V. Kanpp, Logische und..., s. 59.

118 J. Wróblewski, Krytyka normatywistycznej..., s. 37.

119 Zob. G. Simmel, Filozofia kultury; wybór esejów, tłum. W. Kunicki, Eidos, Wydawnictwo UJ, Kraków 2009.

${ }_{120}$ J. Wróblewski, Krytyka normatywistycznej..., s. 49.

121 HP I, t. 1, s. 117. 
winności („tak być powinno”), które obejmują nieomal cała wiedzę na temat otaczającego świata ${ }^{122}$. O ile prawa przyrodnicze jedynie objaśniają rzeczywistość, o tyle norma ma charakter twórczy - dąży do stworzenia nowej jakości, do wywołania określonego zachowania. Kelsen twierdzi ponadto, że forma w przypadku normy ma znaczenie drugorzędne. To samo zdanie w zależności od tego, przez kogo zostanie wypowiedziane może być normą bądź nie (na przykład twierdzenie, że kłamstwo jest szkodliwe w ustach socjologa normą nie będzie, natomiast będzie normą, gdy wypowie je kaznodzieja) ${ }^{123}$. Warto dodać w tym kontekście spostrzeżenie Rosemary Pohlmann, która stwierdza, że o ile u Kanta powinność odnosiła się do pytania o jego treść, o tyle u Kelsena powinność jest pojęciem czysto formalnym ${ }^{124}$.

W przypadku bytu mamy do czynienia z koniecznością: określone następstwo rodzi określony skutek. W naukach normatywnych tej konieczności brak: norma stanowiąca jak być powinno nie musi wcale być spełniona dla swego istnienia $^{125}$. Jak już wspomniano, twórca Czystej teorii prawa, w odniesieniu do dualizmu bytu i powinności, często powołuje się na Simmlera, wskazując, że powinność jest „wyobrażeniem tego, co nie jest jeszcze rzeczywistością, gdyż dopiero powinno stać się rzeczywistością, co jednak nie musi stać się rzeczywistością"126. Zatem rzeczywistość i powinność mogą być ze sobą powiązane, ale takiej konieczności nie ma.

Byt i powinność pozostają według Kelsena ze sobą w nierozerwalnym związku z tego względu, że powinność bez bytu istnieć nie może. Każda norma może istnieć na podstawie faktycznych aktów woli, należących do świata zewnętrznego. Ponadto, system norm obowiązuje w świecie rzeczywistym ${ }^{127}$, a byt i powinność oddziałują na siebie wzajemnie. Obowiązująca norma prawna kształtuje rzeczywistość. Człowiek chcąc nie chcąc nieustannie obraca się w świecie norm zarówno stając na czerwonym świetle, jak i wychowując dzieci ${ }^{128}$. Dla wypełnienia niniejszego postulatu zostały stworzone tzw. Brücken-Prinzipien. Są to maksymy, które tworzą „most” między przepaścią dzielącą byt od powinności ${ }^{129}$.

Pierwsza zasada brzmi: „powinność implikuje możność”. Logiczną konsekwencją tego jest zdanie „niemożność implikuje nie-powinność”. Oznacza to, że przy formułowaniu normy należy mieć na uwadze, czy istnieje realna możliwość jej przestrzegania. Jak już wcześniej wspomniano, według Kelsena wszystkie

122 Ibidem, s. 49.

123 Ibidem, s. 73.

124 R. Pohlmann, Zurechnung und Kausalität, ,Rechtstheorie“ 1985, Bd. 5, s. 94.

125 HP I, t. 1, s. 44-48.

126 Ibidem, s. 49.

127 T. Fritzsche, Die Reine Rechtslehre..., s. 47.

128 Warto jednak zauważyć, że w przypadku wyborów etycznych (mających swe miejsce w świecie kultury) rzadko odpowiedź na pytanie znajduje się w istniejącej wiedzy naukowej (która dotyczy deterministycznego świata przyrody), jednak nie oznacza to, iż wybór ma być nieracjonalny.

129 HP I, t. 1, s. 48-49. 
normy obowiązują wyłącznie warunkowo, albowiem bezcelowym byłoby ustanowienie normy, o której wie się już z góry, że nie może być przestrzegana. Również bezsensowne jest drugie ekstremum, że norma reguluje jako powinność coś, co jest koniecznością. Występuje tu brak różnicy między bytem a powinnością - norma mająca opisywać co być powinno, opisuje co jest. Z punktu widzenia semantyki, mamy zatem do czynienia $\mathrm{z}$ błędnym sformułowaniem zdania. $\mathrm{W}$ istocie - norma „ziemia ma się kręcić wokół słońca” wydaje się być bezużyteczna. Bez względu na jej istnienie ziemia kręci się wokół słońca. Reasumując, norma musi mieścić się pomiędzy tymi dwoma skrajnymi przypadkami. Aby obowiązywała, musi istnieć zarówno możliwość jej przestrzegania, jak i jej naruszenia. Wydaje się jednak, że w tym przypadku warto rozróżnić dwa znaczenia powinności: czy „powinien” jest przeciwstawiony konieczności (wówczas zdanie „ziemia powinna się kręcić wokół słońca" jest zdaniem niepoprawnym, gdyż w tym sensie akcentujemy, że ziemia może, ale nie w każdym przypadku musi się kręcić wokół słońca), czy też powinność jest słabszą odmianą konieczności i wówczas zdanie „ziemia powinna się kręcić wokół słońca" oznacza, że nie tylko powinna, ale również, że dzieje się to w każdym przypadku. Wówczas powinność jednak bardziej przypomina korelację. Wydaje się, że Kelsen miał na myśli pierwsze znaczenie „powinności”.

Druga zasada sprowadza się do postulatu, aby norma była możliwa do spełnienia. Można ją ująć w następujący sposób: „to, co nie może zostać poznane nie powinno ani zostać przez normę uzasadnione, ani uwarunkowane". Jednak z punktu widzenia normy, jeśli sąd błędnie uzna, że X zabił Y, choć w istocie nic takiego nie miało miejsca, to znaczenie ma wyrok sądu nie zaś fakt, że X jest niewinny ${ }^{130}$. Norma zatem w określony sposób kształtuje rzeczywistość wskazując co w niej jest „prawdą” a co „fałszem”. Parafrazując Kanta, można by powiedzieć, że norma kształtuje zjawisko, podczas gdy rzecz sama w sobie (fakt, że X jest niewinny) jest dla nas (często w danej chwili) niepoznawalna.

Trzecią zasadą jest warunek aktu woli. Warunkiem powstania normy jest faktyczny akt woli. Jeśli nie ma aktu woli (sfera bytu), to nie powstanie norma prawna, zatem „coś nie powinno (sfera powinności) być”131. Niniejsze powiązanie istnieje niezależnie od tego, czy normy wymagają tylko hipotetycznego obowiązywania: norma prawna nie istnieje, jeśli nie było aktu woli. Jak z tego wybrnął Kelsen? Pozwiązuje on akt woli z aktem myślowym twierdząc, że akt myślowy go warunkuje. Do tego Kelsen odwołał się do podziału na subiektywny i obiektywny sens aktu woli. Obiektywny sens aktu woli, w odróżnieniu od subiektywnego, zachodzi wówczas, gdy ów akt pochodzi o kompetentnego organu. Dzięki temu, powstaje połączenie między światem bytu i powinności, które nie narusza tezy o rozdziale tych dwóch porządków ${ }^{132}$.

\footnotetext{
130 Ibidem, s. 50.

131 Ibidem, s. 52.

132 S.L. Paulson, Faktum, Wert Distinktion: Zwei-Welten Lehre und immanenter Sinn Hans
} 
Na marginesie warto zwrócić uwagę, na interesującą tezę Bodenheimera, że przełamanie dualizmu bytu i powinności może się przejawiać się również w inny sposób. Tak zwane prawo w książkach jest niewątpliwie refleksem powinności, natomiast prawo w praktyce już nie. Innymi słowy, powinność będąca prawem w książkach przeistacza się w byt, gdy mamy do czynienia z praktyką. Wówczas prawo, jako pewien ideał, zostaje zastąpione prawem, jako rzeczywistość. Jednakże, należy mieć na względzie, że prawo nigdy nie będzie mieć pełnego przełożenia na rzeczywistość. W żadnym społeczeństwie. Zawsze znajdzie się ktoś, kto prawa przestrzegać nie będzie ${ }^{133}$. Nasuwa się wówczas pytanie, jak powinność ma się do obowiązywania normy w Kelsenowskim rozumieniu, przy twierdzeniu, że prawo obowiązuje wówczas, gdy jest przestrzegane. Wydaje się, że można tu znaleźć pewną sprzeczność w jego koncepcji. Jeśli bowiem prawo jest agregatem powinności, to znaczy, że jest naruszane i nieprzestrzegane. Jednak wydaje się, że tę pozorną sprzeczność można w prosty sposób wytłumaczyć: prawo w książkach istnieje niezmiennie. Jest czymś statycznym, co oddziałuje na dynamiczną rzeczywistość. Istnieje obok świata bytu, a nie w nim. To, że dana norma w określonej chwili zostaje naruszona przez adresatów, nie oznacza, że nie obowiązuje w ogóle, Zaś fakt, że w danym momencie idealna norma ze świata powinności przeistacza się $\mathrm{w}$ konkretną normę istniejącą $\mathrm{w}$ rzeczywistości, nie oznacza, że norma idealna przeistoczyła się w normę ze sfery bytu raz na zawsze. Można po arystotelesowsku powiedzieć, że norma ze sfery powinności ma nieskończony potencjał przeistaczania się w normy konkretne, które są przestrzegane, lub nie. To forma, która realizując się w materii tworzy konkretny obiekt. Reasumując, przestrzeganie odnosi się do sfery bytu, law in action, nie zaś do norm idealnych, do prawa w książkach. Naturalnie taka interpretacja wciąż może nasuwać podejrzenia, że jest wbrew intencjom Kelsena, który raczej uwzględniał w swojej teorii zarówno normy generalne jak i indywidualne.

\subsubsection{Dualizm bytu i powinności na płaszczyźnie epistemologicznej}

Jest to najważniejsze przeciwstawienie w fazie neokantowskiej u Kelsena. Pojawia się zarówno w fazie klasycznej, jak i realistycznej. Kelsen zakłada inny sposób poznania bytu i powinności. Jednak Kelsen nie nawiązywał, jakby się można było spodziewać, do Krytyki praktycznego rozumu i „,metafizyki moralności”, lecz odrzucał je, ze względu na ich, w jego mniemaniu, metafizyczny charakter $^{134}$. Zamiast tego, opierał się na Krytyce czystego rozumu i postawionym w niej pytaniu „co możemy wiedzieć?” 135 Podczas gdy byt jest poznawany poprzez

Kelsen als Neukantianer, [w:] R. Alexy, L.H. Meyer, S.L. Paulson, G. Sprenger (Hrsg.), Neukantianismus und Rechtphilosophie, Nomos Verlag, Baden-Baden 2002, s. 232, 250.

${ }_{133}$ E. Bodenheimer, Law as a Bridge Between Is and Ought, „Ratio Juris” 1988, no. 2, s. 140.

${ }^{134}$ H. Kelsen, Die philosophischen Grundlagen..., s. 286.

${ }^{135}$ Fritzsche wskazuje, że nasuwa się tutaj wątpliwość, czy w tej sytuacji bardziej adekwat- 
zmysły, gdzie alogiczny materiał wrażeń porządkowany jest między innymi przez kategorię przyczynowości, to w przypadku powinności miejsce przyczynowości zajmuje zarachowanie, mające ścisły związek z powinnością. Konieczność zarachowania lub powinności jako relatywnej kategorii a priori poparta jest argumentem transcendentalnym. Problemy te zostaną opisane w rozdziale odnoszącym się do drugiej fazy.

\subsubsection{Dualizm bytu i powinności na płaszczyźnie językowej}

W doktrynie dodaje się czwarte rozumienie dualizmu bytu i powinności, na płaszczyźnie językowej. Pohlmann wskazuje, że właśnie to rozumienie ma największe znaczenie dla Kelsena i w tym kontekście najczęściej pisze on o powinności. Chodzi w nim o wyrażenie normatywności prawa, co jest istotne dla przeciwstawienia przyczynowości zarachowania ${ }^{136}$. Ujęcie Pohlmann można nazwać szerokim.To dość ogólne twierdzenie trafnie doprecyzowują Sarkowicz i Stelmach wskazując, że chodzi tu o fakt, że na płaszczyźnie językowej powinność przybiera postać normy ${ }^{137}$.

Podsumowując rozważania z zakresu dualizmu bytu i powinności, należy

nym pytaniem nie jest: „co wolno mi zrobić?” Norma prawna może wyrażać się w formie nakazu, zakazu, bądź przyzwolenia. Pytania adekwatne do każdego z jej typów, to kolejno: „co powinienem robić?”, „,czego mi nie wolno robić?” lub „czego nie powinienem robić?” oraz „,co wolno mi robić”. Zatem, mielibyśmy nie tyle dychotomiczny podział na byt i powinność, co podział na „sein" i przeciwstawiane mu ,sollen”, „können” i „,nicht können”/"nicht sollen”. Jest to zbieżne ze wspomnianym już sposobem rozumienia powinności przez Kelsena w trzeciej i czwartej fazie. Jednak w dwóch wcześniejszych fazach w powinności zawierają się wszystkie trzy wspomniane wyżej elementy. Przenosząc to na kantowską płaszczyznę, ma to dość poważne implikacje, ponieważ obok pytania „co powinienem robić” które w swej treści jednak wskazuje na pewien wybór przed jakim stoi człowiek, pojawiają się również pytania „co mogę”, „co mi (nie)wolno”, które raczej odnoszą się do okoliczności zewnętrznych aniżeli wolnej woli człowieka (T. Fritzsche, Die Reine Rechtslehre..., s. 48). Nie należy zapominać jednak, że Kant stworzył pewne narzędzia, które pozwalają na dokonanie postępu. Neokantyzm nie polega na kurczowym trzymaniu się koncepcji, ale na twórczym wykorzystaniu jego osiągnięć. Przyglądając się czystej teorii prawa przez kantowski pryzmat w omawianym aspekcie, moim zdaniem, z punktu widzenia wolności, mamy do czynienia z trójstopniową strukturą: pierwszy stopień to świat przyrody, sfera „sein”. To świat, w którym człowiek jest niejako uwięziony, ze względu na jego deterministyczny porządek. Drugim światem jest świat norm prawnych - w nim człowiek również pozostaje uwięziony, jednak jest już tu miejsce na pewną uznaniowość - obok pytań o charakterze deterministycznym, pojawia się pytanie - „co powinienem robić". Na najwyższym szczeblu istnieje świat moralności. Tu człowiek staje się wolny i w pełni może swoją ludzkość wyrażać. Naturalnie, w zależności od kryterium podziału na poszczególnych szczeblach hierarchii miejsce poszczególnych światów może się zmieniać. Przykładowo, gdyby za kryterium obrać genealogię, to nie dość, że w zależności od światopoglądu niniejsza hierarchia różnie mogłaby wyglądać, to $\mathrm{z}$ całą pewnością porządek prawa pozytywnego znalazłby się na jej szczycie, jako powstały najpóźniej.

136 R. Pohlmann, Zurechnung und..., s. 95.

137 R. Sarkowicz, J. Stelmach, Filozofia prawa..., s. 46. 
postawić istotne z punktu widzenia czystej teorii prawa pytanie, czy Kelsen jest w stanie obronić swoją podstawową tezę? Jak zostało wykazane, teza ta jest ważna na płaszczyźnie logicznej, natomiast w przypadku płaszczyzny ontologicznej istnieje szereg wyjątków od tej reguły, które sprawiają, że Kelsenowska teoria traci swą spójność. Można spróbować jej bronić, ale często za cenę porzucania innych Kelsenowskich tez. $Z$ drugiej strony warto zadać pytanie, czy ujęcie bytu i powinności na potrzeby czystej teorii prawa, na płaszczyźnie logicznej jako jej fundament, wystarczy. Wydaje się, że jest to możliwe, a dowodem na poparcie tej tezy będzie ostatnia faza twórczości Kelsena, który najwyraźniej coraz bardziej był przekonany do normy jako zjawiska językowego. Natomiast trudno sobie wyobrazić rezygnację $\mathrm{z}$ innych płaszczyzn w tych fazach, w których widoczne są silne wpływy neokantyzmu. To nie oznacza, że w ten sposób teoria Kelsena została zdyskredytowana. Po pierwsze, w przeciwieństwie do nauk ścisłych, w dziedzinie nauk humanistycznych, które są wytworem kulturowym, niespójność teorii w pewnym jej zakresie, jest częstym zjawiskiem. Można nawet zaryzykować twierdzenie, że niespójności pełnią pożyteczną rolę, ponieważ prowokują do dyskusji i tym samym stają się inspiracją dla kolejnych pokoleń badaczy-humanistów. Czysta teoria prawa jest znakomitym tego przykładem. Jeśli się na nią spojrzy jak na projekt stworzenia nauki prawa, projekt tworzony przez kolejne pokolenia, to właśnie jej niedoskonałość może być impulsem dla postępu. Po drugie, zyskiem, który wynika z postulowanej przez Kelsena czystości metodologicznej, jest to, że dzięki temu zostały uzmysłowione mankamenty dziwiętnastowiecznego pozytywizmu prawniczego oraz uwypuklone problemy, z którymi musi się do dziś zmagać teoria prawa. 


\section{Rozdział III Ogólne pojęcie zarachowania i jego typy}

Pojęcie zarachowania nie jest ani pojęciem nowym, ani nie ma charakteru wyłącznie teoretyczno-prawnego. Czerpie swoją tradycję już z XVII w. Wprawdzie w Polsce, w dogmatykach prawniczych nie jest znane, ale na przykład w Niemczech w doktrynie prawa karnego, cywilnego czy nawet prawa ochrony środowiska uznawane jest za przydatne dla zgłębienia zagadnienia odpowiedzialności ${ }^{1}$ Nie jest przedmiotem niniejszych rozważań rozpatrywanie zarachowania w kontekście poszczególnych dogmatyk prawniczych ${ }^{2}$ ze względu na jego teoretyczno-prawny charakter. Warto jednak przedstawić ogólny zarys i takie zadanie zostało postawione przed tym rozdziałem. Najpierw zostanie przedstawiony krótki opis historyczny ewolucji pojęcia zarachowania, by następnie ogólnie wskazać, jak ono funkcjonuje współcześnie. Wydaje się to dobrym punktem wyjścia dla szczegółowych rozważań na temat zarachowania w czystej teorii prawa.

Zarachowanie jest szerokim pojęciem. Występuje nie tylko w prawie. Można na przykład mówić o zarachowaniu gospodarczym, zarachowaniu w odniesieniu do reguł etycznych, a w dziedzinie prawa o zarachowaniu prawno-politycznym i prawno-teoretycznym. Jednak głównym przedmiotem zainteresowania Kelsena jest zarachowanie prawne, dokonane na podstawie normy prawnej lub w niej zawarte. Myliłby się jednak ten, kto przyjąłby, że Kelsen dokonał prostej recepcji tego pojęcia, tak jak funkcjonowało ono w tradycji filozoficznej. Tradycyjny sposób rozumienia zarachowania został przez Kelsena praktycznie odrzucony, a w jego miejsce wprowadzone nowe konstrukcje. Dla opisu zarachowania w tradycyjnym ujęciu (które nazwałam klasycznym) warto na wstępie ogólnie wskazać, w jakich znaczeniach Kelsen posługiwał się tym pojęciem. Pozwoli to na choćby pobieżne zorientowanie się $\mathrm{w}$ podobieństwach i różnicach między klasycznym a kelsenowskim rozumieniem. U Kelsena można wyróżnić zarachowanie peryferyjne, zarachowanie centralne (zwane później przypisaniem), zadośćuczynienie oraz zarachowanie naturalne.

${ }^{1}$ Zob. np. G. Teubner, Die unsichtbare „Copula“: Kausalitäatkrise und kollektive Zurechnung, [w:] W. Lübbe (Hrsg.), Kausalität und Zurechnung. Über Verantwortung in komplexen kulturellen Prozessen, Walter de Gruyter, Berlin, New York 1994, s. 91-143; L. Schulz, Kausalität und strafrechtliche Produkthaftung. Materiell- und prozeßrechtliche Aspekte, [w:] ibidem, s. 41-85.

2 Tematykę relacji czystej teorii prawa do prawa karnego porusza w obszernej monografii R. Lippold. Zob. R. Lippold, Reine Rechtslehre und Strafrechtdoktrin, Springer Verlag, Wien, New York 1989. 
Zarachowanie peryferyjne dotyczy związku między stanem rzeczy określonym w poprzedniku zdania hipotetycznego oraz stanem rzeczy określonym w następniku. Zdania prawne można porównać ze zdaniami funkcjonującymi w naukach opartych na zasadzie przyczynowości. O ile w tych drugich schemat zdania przedstawia się jako: ,kiedy A, to jest B”, to w naukach prawnych brzmi on następująco: „kiedy A, to powinno B”. Istnieje w nim zatem powiązanie warunku i następstwa, czyli bezprawia i konsekwencji związanych z tym bezprawiem w postaci zarachowania. Jego gramatycznym wyrazem jest słowo „powinien”, podczas gdy w zdaniach dotyczących świata natury przejawem związku przyczynowo-skutkowego będzie słowo „musi” albo ,jest”3.

Zarachowanie centralne dotyczy relacji pomiędzy stanem rzeczy określonym w następniku a osobą. Polega na przypisaniu określonej osobie działania opisanego w następniku. Jego konstrukcja jest zbliżona do ogólnie przyjętej konstrukcji zarachowania, opisywanej przez Kanta i Pufendorfa. Może zarówno dotyczyć państwa jako osoby, jak i innych pomiotów prawa: osób fizycznych i osób prawnych. Zasadniczą różnicą jest to, że osoby fizyczne i osoby prawne Kelsen dość często kwalifikuje jedynie jako tzw. punkty przejściowe, tak naprawdę eliminując te pojęcia z konstrukcji normy prawnej, zaś końcowym punktem zarachowania jest zawsze podmiot $\mathrm{w}$ postaci państwa ${ }^{4}$.

Zadośćuczynienie - pojawia się w trzeciej fazie, najpierw w obszernej monografii z dziedziny etnologii Vergeltung und Kausalität, następnie w drugim wydaniu Czystej teorii prawa. Zadośćuczynienie jest specyficznym rodzajem zarachowania, które przez to, że łączy nagrodę lub karę za uczynki, gwarantuje wolność woli5. Jego znaczenie ujawnia się głównie poza prawem.

Zarachowanie naturalne pojawia się u Kelsena w Grundriß einer allgemeinen Theorie des Staates. Według niego ma miejsce wtedy, gdy pewną całość zarachowuje się na podstawie części. Na przykład, twierdzi się, że ptak śpiewa, chociaż za dźwięk odpowiedzialna jest jego grdyka. Od zarachowania normatywnego różnią go dwie cechy: po pierwsze, odnosi się bezpośrednio do zmysłów, po drugie, odnosi się do wszelkich zjawisk w przyrodzie. W odróżnieniu od niego zarachowanie normatywne odnosi się tylko do pewnej klasy zjawisk: opisanych w normach prawnych ${ }^{6}$.

Przedstawione rodzaje zarachowania, w szczególności zarachowanie peryferyjne, jak większość elementów teorii Kelsena przechodziły ewolucję. Zmieniało się ich znaczenie i funkcje, co będzie drobiazgowo prześledzone później.

3 RR1, s. 34.

${ }^{4}$ C. Heidemann, Der Begriff der Zurechnung bei Hans Kelsen, [w:] S.L. Paulson, M. Stolleis (Hrsg.), Hans Kelsen Staatsrechtslehrer und Rechtstheoretiker des 20. Jahrhunderts, Mohr Siebeck, Tübingen 2005, s. 23.

${ }^{5}$ RR2, s. 86-88; C. Heidemann, Die Norm als Tatsache. Zur Normentheorie Hans Kelsen, Nomos Verlagsgesellschaft, Baden-Baden 1997, s. 131.

${ }^{6}$ H. Kelsen, Grundriß einer allgemeinen Theorie des Staates, Wien 1926, s. 11-12. 
W niniejszym rozdziale omówiony zostanie najpierw zarys historyczny ewolucji tego pojęcia u wybranych myślicieli, następnie jego współczesne znaczenia, by na końcu poruszyć problem relacji zarachowania i przyczynowości.

\subsection{Zarys historyczny ewolucji pojęcia zarachowania}

\subsubsection{Samuel Pufendorf}

Pierwotnie na zjawisko zarachowania zwrócił uwage już Platon w Timajosie, a następnie Arystoteles w Etyce Nikomachejskiej. Jednak dopiero Pufendorf jako pierwszy użył pojęcia ,imputatio” i stworzył całą jego teorię7. Pufendorf był dzieckiem Racjonalizmu. Zdobywając wykształcenie, dość szybko znalazł się pod wpływem nowej w owym czasie myśli Kartezjusza, Hobbesa, Grocjusza oraz odkryć Galileusza ${ }^{8}$. Konstrukcję zarachowania u Pufendorfa doskonale objaśnił Welzel, wskazując, że punktem wyjścia są dwa typy determinacji w świecie fizycznym: porządek deterministyczny charakteryzowany przez powiązania przyczynowo-skutkowe i determinacja przez wolność. Pierwszemu podlegają zdarzenia nie mające swego źródła w zachowaniach ludzkich i niektóre ludzkie zachowania mające swoje miejsce w porządku deterministycznym. Drugiemu determinacja przez wolność, której podlegają zachowania czerpiące swe źródło z wolnej woli człowieka9. Wolność jest immanentną cechą woli człowieka, mającą swój wyraz w obojętności (indifferenz) i wolnym samostanowieniu. Obojętność polega na stosunku woli do potencjalnego zachowania, gdzie brak jest konieczności wyboru takiej, a nie innej możliwości. Wolne samostanowienie z kolei oznacza, że wybór zachowania pochodzi z woli. Wolność zachowań polega zatem na wiedzy, co jest obiektem woli. Tym samym jest domeną rozumu, który wydaje sąd, w jaki sposób należy się zachowywać i niesie ze sobą możliwość zarachowania sprawcy określonej czynności. W wolnym działaniu można wyróżnić moment materialny oraz formalny. Moment materialny sprowadza się do fizycznych zdarzeń dotyczących zachowań, czyli ruchu ciała, i przyczynowo nim spowodowanych dalszych zdarzeń (na przykład: lot kamienia, wybita szyba). Formalność dotyczy zarachowalności (Zurechnenbarkeit) zachowania, polegającej na tym, że działającemu czyn może zostać zarachowany. Zarachowalność ma z punktu widzenia wartości charakter obojętny. Jej zadaniem nie jest stwierdzenie o winie, lub niewinności, ale ukazanie logicznych powiązań w sferze wolności ${ }^{10}$. Wyraźnie

7 E. van Alphen, Kelsen and Hruschka: Concepts of Imputation, „International Journal for the Semiotics of Law" 1993, vol. VI, no. 17, s. 163, przyp. 1.

${ }^{8}$ T. Behme, Samuel von Pufendorf Naturrecht und Staat, Vandenhoeck \& Ruprecht, Göttingen 1995, s. 14.

${ }^{9}$ H. Welzel, Die Naturrechtslehre Samuel Pufendorfs, Walter de Gruyter \& Co., Berlin 1958, s. 21.

${ }^{10}$ Ibidem, s. 21-23. 
tu widać u Pufendorfa udaną próbę zmierzenia się z zagadnieniem wolnej woli w świecie mechanistycznym. Zarachowanie jest odpowiedzią na pytanie, gdzie jest miejsce na wolną wolę w deterministycznym świecie powiązań przyczynowo-skutkowych.

Moment zarachowalności ma również zastosowanie do prawa pozytywnego. Punktem wyjścia jest tu oparcie ludzkich zachowań na wolnej woli, co odróżnia je od zachowań wbrew woli podmiotu (na przykład będzie to wykonanie rozkazu albo wybór mniejszego zła). Takie zachowania, stwierdza Pufendorf, nie mogą być tak samo zarachowane jak zachowania z wolnej woli. Tylko te, którym towarzyszyła zarówno wolna wola, jak i wiedza, podlegają zarachowaniu. Dopiero wtedy człowiek może być postrzegany przez prawo jako sprawca lub zobowiązany ${ }^{11}$. Nie można zatem zarachować człowiekowi zachowania, jeśli nie był „,panem samego siebie, albo panem swoich czynów"12. Z powyższej zasady Pufendorf formułuje reguły szczegółowe dotyczące zarachowania. I tak:

1. Zachowania innych ludzi lub zwierząt mogą być zarachowane podmiotowi jedynie wówczas, gdy on może i musi je kontrolować. Przykładem tutaj może być szkoda wyrządzona przez czyjeś zwierzę.

2. Zarachowane nie mogą być te przypadki, które dotyczą posiadania lub braku określonych cech u podmiotu, co uniemożliwia mu zachowanie zgodne z prawem. Jako przykład Pufendorf podaje niemożność czynienia zarzutu rolnikowi z tego, że nie zna zasad wychowania, chociaż jest to możliwe w przypadku kogoś należącego do mieszczaństwa albo stanu szlacheckiego.

3. Nie podlega zarachowaniu również to, co jest nieprzezwyciężoną niemożliwością (unüberindbare unkenntnis).

4. Z kolei niewiedza albo błąd nie chronią przed zarachowaniem ze względu na obowiązek dołożenia należytej staranności, by wiedzę o prawie, przynajmniej w tej dziedzinie, która go dotyczy, posiadać.

5. Nie można zarachować zaniechania, jeśli brak jest możliwości odpowiedniego działania. Pufendorf wyjaśnia, że możliwość odpowiedniego działania zachodzi wówczas, gdy spełnione są cztery warunki: po pierwsze, podmiot zachowania jest w zasięgu (Reichweite); po drugie, zachodzi tożsamość miejsca; po trzecie, że zachodzi tożsamość czasu, w którym nie zachodzi kolizja obowiązków; po czwarte, osoba zobowiązana ma odpowiednie możliwości, aby dany obowiązek spełnić (na przykład jest lekarzem).

6. Nie można zarachować jako winy, niewykonania zobowiązania, które jest niemożliwe do spełnienia, pod warunkiem, że zobowiązany sam nie doprowadził do niemożliwości.

7. Nie podlegają zarachowaniu czynności dokonane pod wpływem przymusu lub groźby.

\footnotetext{
${ }^{11}$ Ibidem, s. 32.

12 Ibideme, s. 33.
} 
8. Czyny osób chorych psychicznie lub upośledzonych umysłowo nie mogą być zarachowane.

9. Nie podlegają zarachowaniu czyny popełnione podczas snu, o ile sprawca nie wywołał snu poprzez rozmyślanie na temat czynu podczas dnia. Pufendorf wyraźnie zaznacza, że ten przypadek raczej nie może mieć zastosowania praktycznego ze względu na trudności dowodowe ${ }^{13}$.

W przypadku odpowiedzialności osób trzecich Pufendorf zauważa, że rzadko ma miejsce sytuacja, gdy jedna osoba (ewentualnie zwierzę) jest bezwolnym narzędziem, zaś czyn w całości zarachowany jest innej osobie. Najczęściej zachodzi przypadek współodpowiedzialności, w którym można wyróżnić trzy sytuacje: po pierwsze, można mieć do czynienia z głównym sprawcą oraz osobą, która faktycznie czyn popełnia, ale jej wkład w popełnienie czynu jest znacznie mniejszy (na przykład działanie na rozkaz); po drugie, gdy udział wszystkich podmiotów w popełnieniu czynu jest taki sam (na przykład, gdy żaden z przechodniów nie udzielił pomocy rannemu); po trzecie, gdy głównym sprawcą jest osoba popełniająca czyn, ale poza nią jest jeszcze ktoś mający pewien, mniejszy wkład w jego popełnienie (na przykład udziela rady jak popełnić przestępstwo) ${ }^{14}$.

Rozważania Pufendorfa dotyczące zarachowania były nowatorskie i dość szybko zyskały rozgłos. Zostały recypowane najpierw przez Wolffa, a później przez jego ucznia - Kanta.

\subsubsection{Immanuel Kant}

Na płaszczyźnie etyki koncepcja zarachowania upowszechniła się dzięki Kantowi. Definiując zarachowanie, Kant stwierdza, że:

Działanie staje się czynem lub uczynkiem (Tat), gdy podpada pod zasadę obowiązku; wówczas też dysponujący wolą arbitralną podmiot jest do niego zobowiązany. Dzięki temu, ten, kto dokonuje działania (Wirkung), uważany jest za jego sprawcę (Urheber); działanie to w całym jego przebiegu przypisać (zugerechnet) można osobie sprawcy, pod warunkiem jednak, że potrafimy przywołać prawo, w którym umocowane jest stosowne zobowiązanie ${ }^{15}$.

Dalej Kant podaje definicję zarachowania:

Przypisanie (imputatio) działania osobie jest stwierdzeniem moralnego sprawstwa (causa libera) dokonanego czynu (factum), który podpada pod określone prawo ${ }^{16}$.

${ }^{13}$ S. von Pufedorf, Über die Pflicht des Menschen und des Bürgers nach dem Gesetz der Natur, Insel Verlag, Frankfurt am Main, Leipzig 1994, s. 33-37, 74.

${ }^{14}$ Ibidem, s. 74-75.

${ }^{15}$ I. Kant, Metafizyka moralności, thum. Ewa Nowak, Wydawnictwo Naukowe PWN, Warszawa 2007, s. 31; należy zwrócić uwagę, że w zacytowanym przekładzie słowo „zarachowanie" nie występuje. Zastąpione jest najczęściej wyrazem „,przypisanie”.

${ }_{16}$ Ibidem. 
Jak należy rozumieć tę definicję? Można w niej wyróżnić kilka kluczowych elementów: osobę sprawcy, zachowanie oraz element ,podpadania pod określone prawo". Odnośnie do pierwszego pojęcia, Hruschka zwraca uwagę, że sprawcą czynu jest tylko ten, kto jest jego causa libera ${ }^{17}$, czyli ma swobodę działania. Z kolei pojęcie zachowania (Handlung), według Paulsona kluczowe, pomimo że zazwyczaj dotyczy zachowań ludzkich, to w tym wypadku powinno być raczej rozumiane jako „zdarzenie” (Ereignis), czyli jako coś, co można zarachować podmiotowi. Jeśli natomiast chodzi o użyte przez Kanta słowo „czyn” (factum), to zostało ono dobrze przełożone na język polski, ponieważ nie chodzi o fakt ${ }^{18}$. W przypadku trzeciego elementu Paulson uznaje to sformułowanie za wymagające bliższego wyjaśnienia. W tym kontekście, należy zwrócić uwagę na to, że Kant wyróżniał trzy możliwe sytuacje zastosowania prawa. Po pierwsze, zachowanie może wykraczać poza to, co nakazuje akt prawny (na przykład, zobowiązanie do wpłacenia określonej sumy na PCK, X wpłaca sumę wyższą); po drugie, zachowanie odpowiada temu, co jest wyrażone w akcie prawnym; po trzecie, jest niezgodne $\mathrm{z}$ postanowieniami zawartymi $\mathrm{w}$ akcie prawnym. Paulson podsumowuje, że zarachowanie w Kantowskim ujęciu polega na tym, że określone zdarzenie zostaje zarachowane pewnemu indywiduum, najczęściej sprawcy, zaś przesłanką zarachowania jest właśnie to zdarzenie, za które to indywiduum jest odpowiedzialne ${ }^{19}$.

Koncepcja zarachowania Kelsena wyraźnie odbiega od Kantowskiej. J. Hruschka wskazuje na kilka zasadniczych różnic, które doprowadzają do konkluzji, że Kelsen zapożyczył od Kanta jedynie terminologię ${ }^{20}$. Pierwszą z nich jest perspektywa, w której zostaje ujęte zachowanie. Można tu wyróżnić prospektywny i retrospektywny punkt widzenia. Prospektywny punkt widzenia oznacza branie pod uwagę zachowań, które mogą mieć miejsce w przyszłości i spełnia funkcję kształtującą. Retrospektywny dotyczy zachowań z przeszłości i pełni rolę miary. W przypadku prospektywności funkcjonuje zasada, że powinność implikuje możność, natomiast retrospektywne zastosowanie normy implikuje zarachowanie. Hruschka wskazuje, że Kant patrzy na zachowanie zarówno od strony prospektywnej, jak i retrospektywnej, i są one dwiema stronami tego samego medalu. Kelsen natomiast wyłącznie retrospektywnie ${ }^{21}$. To stwierdzenie wymaga wyjaśnienia, nie do końca bowiem jest jasne, co oznacza retrospektywne ujęcie zarachowania w czystej teorii prawa. Wydaje się, że Hruschka ma na myśli nor-

${ }_{17}$ J. Hruschka, Die Zurechnungslehre Kelsens in Vergleich mit der Zurechnungslehre Kants, [w:] S.L. Paulson, M. Stolleis (Hrsg.), Hans Kelsen..., s. 8.

18 S.L. Paulson, Die Zurechnung als apriorische Kategorie in der Rechtslehre Hans Kelsens, [w:] M. Kaufmann, J. Renzikowski (Hrsg.), Zurechnung als Operationaliesierung von Verantwortung, Peter Lang, New York 2004, s. 98.

19 Ibidem, s. 98-101.

20 J. Hruschka, Die Zurechnungslehre..., s. 7-16.

${ }^{21}$ Ibidem, s. 7. 
mę wtórną, którą podmiot musi naruszyć, by organ zastosował sankcję. Wówczas byłoby to faktycznie zarachowanie klasyczne, jednak warto mieć na uwadze, że Kelsen jest zdania, że nie potrzeba tu żadnego łącznika, ponieważ nie da się oddzielić osoby od jej zachowania i nawet gdy rozpatruje się odpowiedzialność za cudze czyny, to i tak wynika ona z winy w nadzorze ${ }^{22}$. Wydaje się, że u Kelsena dominuje ujęcie prospektywne w przypadku norm generalnych i retrospektywne, w przypadku norm indywidualnych. $Z$ odrzuceniem przez Kelsena zarachowania klasycznego nie zgadza się Renzikowski, będąc zdania, że tradycyjne zarachowanie nie odpowiada na pytanie, czy ktoś w dany sposób się zachował, lecz czy jego zachowanie miało znaczenie moralne (ewentualnie prawne), zaś w przypadku osób, którym zarachować zachowania nie można, ma miejsce nie causa libera, ale niemająca odniesienia do prawa actio naturalis ${ }^{23}$. Obok zarzutu Renzikowskiego rodzi się pytanie o zasadę ryzyka, na przykład przy odpowiedzialności z art. 435 k.c. za szkodę wyrządzoną przez ruch przedsiębiorstwa. Zasada ryzyka ze swojej definicji wyłącza uwzględnienie zachowania osoby odpowiedzialnej (przedsiębiorcy), a jednak to jej ową odpowiedzialność się zarachowuje. Wydaje się zatem, że twierdzenie Kelsena o braku konieczności wprowadzania konstrukcji zarachowania klasycznego do rozważań prawnych jako konstrukcji wadliwej jest bezpodstawne.

Przedstawiona przez Hruschkę interpretacja pociąga według niego dalsze konsekwencje: Kant ma na uwadze przede wszystkim ludzi jako adresatów normy. Dla Kelsena adresatami norm są organy państwowe. Jeśli jednostki nie podporządkują się normom, to zostanie wobec nich zastosowana przez organ sankcja ${ }^{24}$. U Kanta punktem wyjścia jest wolność, a w konsekwencji wolna wola - aby zarachowanie miało miejsce, to sprawca czynu musi być jego casua libera. Natomiast Kelsen wstępnie odrzuca koncepcję wolnej woli u jednostek, ze względu na uwikłanie jej w łańcuch powiązań przyczynowo-skutkowych. Kelsen nie neguje, że człowiek jest zdolny modyfikować swoje zachowanie na mocy woli. Twierdzi jedynie, że sama wola jest przyczynowo zdeterminowana, dlatego nie jest wolna. Dzięki woli w takiej postaci możliwe jest zarówno zarachowanie w sferze moralnej, jak i prawnej. Na samo zaś pytanie, dlaczego tylko ludziom można przypisać odpowiedzialność, Kelsen odpowiada, że nie ze względu na wolną wolę, wyróżniającą człowieka spośród innych istot, tylko dlatego, że obecnie normy dotyczą ludzkiego działania ${ }^{25}$. Kelsen konkluduje, że „zarachowanie nie jest możliwe, dlatego że ludzie są wolni, tylko dlatego są wolni, ponieważ tak im zarachowano"26.

${ }^{22}$ RR2, s. 85.

23 J. Renzikowski, Der Begriff der ,Zurechnung” in der Reinen Rechtslehre Hans Kelsens, [w:] R. Alexy, L.H. Meyer, S.L. Paulson, G. Sprenger (Hrsg.), Neukantianismus und Rechtphilosophie, Nomos Verlagsgesellschaft, Baden-Baden 2002, s. 273.

${ }^{24}$ Ibidem.

${ }_{25}$ RR2, s. 97, 100.

${ }^{26}$ Ibidem, s. 102. 
Oznacza to tyle, że wolność ma miejsce dopiero wtedy, gdy określonemu czynowi została zarachowana konsekwencja w postaci nagrody lub kary. Wynika $\mathrm{z}$ tego, że „człowiek jest wolny, ponieważ jego zachowanie jest końcowym punktem zarachowania"27. Jak zauważa Kelsen, nie da się zatem na mocy tej wolności wyeliminować przyczynowości ${ }^{28}$. Hruschka wskazuje, że wspominając o wolności, Kelsen nadaje temu pojęciu nowe znaczenie. Ta wolność musi być zgodna z uwarunkowaniami przyczynowości. Jak podsumowuje Hruschka:

Wolny, to [...] pewna relacja, etykietka dla człowieka, któremu jakąś karę, albo nagrodę przyznano [....] Więcej ,wolny" u Kelsena nic nie znaczy ${ }^{29}$.

Dalej Hruschka, zastanawiając się, dlaczego Kelsen w tej sytuacji odwołuje się do pojęcia wolności, dochodzi do wniosku, że po pierwsze, z tego względu, że słowo „wolność” i pojęcie zarachowania pasują do siebie (a Kelsen stara się dopasować terminologie do języka potocznego), po drugie, ze względu na wielki autorytet, jakim był dla twórcy czystej teorii prawa Kant ${ }^{30}$. Nie bez znaczenia jest również przeinaczenie przez Kelsena słów Kanta, że wolność jest tylko fikcją ${ }^{31}$. Na zakończenie Hruschka pyta, jak doszło do tego, że Kelsen źle zinterpretował Kanta. Jednego z powodów upatruje właśnie w tym, że Kelsen nie bierze pod uwagę prospektywnego spojrzenia na ludzkie zachowania, które jest jedynym możliwym dla rozpatrywania zagadnienia wolności. Z retrospektywnego punktu widzenia trudno o wolności coś powiedzieć. U Kanta jednostka, mimo że uwikłana w deterministyczny świat przyrody, jest wolna w sensie moralnym i jako istota myśląca może swoją wolność realizować.

Dokonując podsumowania, można stwierdzić, że w tym wypadku Kelsen przejął terminologię od Kanta. Wynika z tego, że w czystej teorii prawa można znaleźć wątki, strukturę wyraźnie nawiązujące do koncepcji kantowskich. Choć nie zawsze jest to wyrażone wprost (we wcześniejszych fragmentach owe analogie zostały wskazane), można znaleźć również bezpośrednią recepcję terminologii kantowskiej z drobnymi modyfikacjami poczynionymi na potrzeby teorii prawa i można (tak jak w przypadku zarachowania) znaleźć terminologię pozornie nawiązującą do Kantowskich koncepcji, lecz w swej treści zupełnie odmienną. Stąd potrzeba tak drobiazgowej analizy Kelsenowskiej terminologii, ponieważ ograniczenie się wyłącznie do „czytania Kelsena” przez pryzmat filozofii Kanta może doprowadzić do błędnego zrozumienia jego teorii.

${ }^{27}$ Ibidem; warto zwrócić uwagę, że mowa tu o zachowaniu jako końcowym punkcie zarachowania peryferyjnego. Czym innym jest końcowy punkt zarachowania centralnego, czyli państwo.

28 Ibidem.

29 Ibidem, s. 9.

30 J. Hruschka, Die Zurechnungslehre..., s. 9-10.

31 Por. ibidem, s. 11-12. 


\subsection{Współczesne zastosowanie pojęcia zarachowania}

$\mathrm{Na}$ wstępie warto wyjaśnić ogólną definicję zarachowania na gruncie trzech języków: niemieckiego, angielskiego i polskiego. W oksfordzkim słowniku języka angielskiego pojęcie zarachowania (impute) thumaczy się następująco:

reprezentuje (coś, w szczególności coś niepożądanego), jako dokonane (zrobione), albo posiadane przez kogoś; przypisywać: np. przestępstwa zarachowane Ryszardowi ${ }^{32}$.

W literaturze anglojęzycznej dotyczącej pism Kelsena można jednak trafić również na inne thumaczenie: „accounting” ${ }^{33}$. Nie wydaje się ono jednak w dziedzinie prawa trafione. Ewentualnie można się zastanawiać, czy zasadne byłoby odnosić to sformułowanie do zarachowania gospodarczego. Za wyborem ,imputation” świadczy słowo „etymologia” - pochodzące od łacińskiego imputatio, które stosowali Pufedorf, Wolff i Kant.

$\mathrm{Z}$ kolei w języku niemieckim, w słowniku Langenscheidta podano następujące definicje:

Zarachować - coś przyporządkować.

Podlegający zarachowaniu - w sytuacji normalnego i jasnego myślenia (z ustawy) być odpowiedzialnym za swoje czyny.

W obu wersjach definicji widoczne jest wyraźnie nawiązanie do klasycznego rozumienia zarachowania, ustalonego w filozofii.

W języku polskim wybór pojęcia „zarachowanie” nie jest do końca oczywisty. W Uniwersalnym słowniku języka polskiego podano bardzo ogólną definicję: „zaliczyć na poczet czegoś”34. W thumaczeniach na język polski można się spotkać z innymi określeniami, na przykład ,poczytanie” (u Landego), ale najczęściej, w szczególności w tłumaczeniach Kanta, „przypisanie”, definiowanego przez słownik jako „ustanowienie związku czegoś z czymś” albo uznanie, ,że coś jest przyczyną czegoś" ${ }^{35}$. Jak widać, z podanych definicji wynika, że trafniejszym thumaczeniem byłoby „przypisanie”, jednak o wyborze „zarachowania” jako słowa lepiej oddającego niemieckie „Zurechnung” zadecydowały trzy względy. Po pierwsze, tradycja przedwojennych thumaczeń, przede wszystkim Przeorskiego; po drugie, fakt, że jest to dosłowne tłumaczenie z języka niemieckiego

${ }^{32} \mathrm{http} / / /$ oxforddictionaries.com/view/entry/m_en_gb0403640\#m_en_gb0403640.008 [22 VII 2010].

${ }^{33}$ Zob. H. Kelsen, Causality and Accounting, [w:] H. Kelsen, Essays in Legal and Moral Philosophy; selected and with an introduction by Ota Weinberger, trans. P. Heath, Reidel, Dordrecht 1973, s. 156-164.

${ }^{34}$ http://usjp.pwn.pl/haslo.php?id=1895274 [29 VII 2010].

35 http://usjp.pwn.pl/haslo.php?id=1869481 [29 VII 2010]. 
(od „rechnen” - „rachować”); po trzecie, wprowadzenie przez Kelsena w trzeciej fazie pojęcia „Zuschreibung”, które dosłownie się thumaczy na polski jako „,przypisanie” (od „schreiben” - „pisać").

Zarachowanie prawne, pełniące tę samą rolę w świecie powinności co przyczynowość w świecie bytu, następuje na zasadzie normy i jest relacją między jej podmiotem a przedmiotem albo relacją pomiędzy dwoma elementami normy prawnej: zachowaniem w niej opisanym i sankcją ${ }^{36}$. Ma ono miejsce, ponieważ „coś powinno lub nie powinno się było stać...”. Oznacza to, że ustanawiana jest powinność zarachowania i w tym sensie słowo „powinno” pełni tę samą rolę co słowo „musi” w świecie przyczynowości ${ }^{37}$. Hruschka uważa, że jeśli ktoś stwierdzi, że „zachowanie jest zastosowaniem reguły”, że nie jest to stwierdzenie na płaszczyźnie ontologicznej, ponieważ nie można przyjąć, że ruch albo dźwięk może po prostu zostać uznany za posiadający znaczenie prawne albo moralne. Do tego konieczne jest nadanie znaczenia, czyli czegoś, co wychodzi od człowieka, gdy określone zdarzenie jest postrzegane jako reguła prawna. Temu właśnie służy zarachowanie ${ }^{38}$. Zarachowanie nie ma zatem miejsca, gdy nie da się określonego ruchu ciała, dźwięku poczytać jako mającego doniosłość z punktu widzenia prawnego bądź moralnego. Taka sytuacja na gruncie prawa odnosi się do faktów prawnie indyferentnych, natomiast z punktu widzenia moralności chodzi o sytuację, gdy podmiot albo nie jest w stanie powziąć wiedzy o regułach moralnych (na przykład jest chory psychicznie, albo śpi), albo jest w stanie, ale i tak jej nie ma (niemożność fizyczna, siła wyższa) ${ }^{39}$.

Jednym z problemów omawianych $\mathrm{w}$ doktrynie, który wiąże się z zarachowaniem, jest pytanie o reguły mające zastosowanie w danym wypadku. Nie da się bowiem przyjąć, że dany fakt ma doniosłość prawną bądź moralną jedynie poprzez stwierdzenie, że podmiot jakimś regułom podlega ${ }^{40}$. Aby zarachowanie miało miejsce, musi również istnieć możliwość stwierdzenia, że czyn podlegający zarachowaniu miał miejsce. Nie dojdzie do zarachowania ani na płaszczyźnie moralności, ani na płaszczyźnie prawnej, jeśli określony fakt nie zostanie poddany krytyce. W konsekwencji tego twierdzenia w XVIII w. wyodrębniono dwa rodzaje zarachowania: imputatio facti oraz imputatio iuris. Obok tego podstawo-

${ }^{36}$ HP I, t. 1, s. 123; W. Ebenstein, The Pure Theoryof Law: Demythologizing Legal Thought, „California Law Review” 1971, vol. 59, s. 635; C. Jabloner, Beiträge zur einer Sozialgeschichte der Denkformen: Kelsen und die Einheitswissenschaft, [w:] C. Jabloner, F. Stadler (Hrsg.), Logische Empirismus und Reine Rechtslehre; Beziehungen zwischen dem Wiener Kreis und der Hans Kelsens-Schule, Veröffentlichungen des Instituts Wiener Kreis Springer, Wien, New York 2001, s. 23;

J. Hruschka, Strukturen den Zurechnung, Walter de Gruyter, Berlin, New York 1976, s. 13.

${ }_{37}$ HP I, t. 1, s. 204, R. Hendler, Die Staatstheorie Hans Kelsens, Juristische Schulung,

C.H. Beck, München 1972, s. 490.

38 J. Hruschka, Strukturen..., s. 13.

39 Ibidem, s. 15-18.

${ }^{40}$ Ibidem, s. 19-26. 
wego podziału można wyróżnić imputatio physica, podobne do imputatio facti oraz imputatio moralis, polegające na zarachowaniu określonego zachowania jako krytykowanego z moralnego punktu widzenia. Wszystkie powyższe rodzaje zarachowania składają się na imputatio plena, czyli zarachowanie pełne ${ }^{41}$.

Imputatio facti polega na poczytaniu określonego faktu jako zachowania doniosłego z punktu widzenia określonych reguł (Vorgang als Handlung). Z kolei imputatio iuris sprowadza się do zarachowaniu tego zachowania jako podjętego wbrew regułom. Obu rodzajom odpowiadają inne normy. Reguły pozwalające na kwalifikację czynu w określony sposób (na przykład, wskazując, że nie jest zabójstwem oczekiwanie aż w określoną osobę uderzy meteoryt, ponieważ z zasad doświadczenia wynika, że prawdopodobieństwo tego jest znikome) dotyczą zarachowania faktycznego. Natomiast normy dotyczące zarachowania prawnego mają inny charakter. Nie wynikają z reguł doświadczenia, nie wskazują, w jaki sposób można dokonać zabójstwa. Opierając się natomiast na ocenach, pozwalają stwierdzić, czy dany czyn jest nakazany, zakazany albo dozwolony ${ }^{42}$. Aby można było bliżej wyjaśnić podział na imputatio facti i imputatio iuris, należy osadzić oba te pojęcia w szerszym kontekście, którym są reguły zachowania i reguły zarachowania.

Jak już wspomniano, zasady zachowania spełniają dwie funkcje: prospektywną oraz retrospektywną. Z punktu widzenia funkcji prospektywnej reguły zachowania postrzegane są jako nakazy, zakazy i dozwolenia dotyczące danego podmiotu. Ich zadaniem jest wpływ na kształt życia społecznego. Natomiast funkcja retrospektywna dostarcza miary, za pomocą której można ocenić, czy dane zachowanie jest zgodne, czy niezgodne z prawem, czy jest deliktem, czy też podlega zwolnieniu od odpowiedzialności. I tak naruszenie zakazu rodzi delikt z działania, naruszenie nakazu - delikt z zaniechania; natomiast dozwolenie wskazuje na zwolnienia od odpowiedzialności ${ }^{43}$.

Inaczej sprawa się przedstawia przy zasadach zarachowania. Tu nacisk położony jest przede wszystkim na funkcję retrospektywną, pozwalając sędziemu na ocenę danego czynu. I właśnie wśród reguł zarachowania można wyróżnić imputatio facti, zwane również zarachowaniem pierwszego stopnia i imputatio iuris, czyli zarachowanie drugiego stopnia. Stanowią one kolejne etapy procesu zarachowania pełnego ${ }^{44}$. Warunkiem zarachowania faktycznego jest przyjęcie, że sprawca czynu posiadał możliwość alternatywnego zachowania się. Jest to pochodna zasady „powinność implikuje możność”. Zasada ta wymaga założenia

${ }^{41}$ Ibidem, s. 30-36; J. Hruschka, Verhaltensregeln und Zurechnungsregeln, „Rechtstheorie“ 1991, Bd. 22, s. 132; R. Lippold, Reine Rechtslehre..., s. 102-103.

42 Ibidem, s. 133.

${ }^{43}$ J. Hruschka, Verhaltensregeln ..., s. 450; jak podaje van Alphen, ta konstrukcja w szczególności jest wykorzystywana w niemieckim prawie karnym (E. van Alphen, Kelsen and..., s. 172).

${ }_{44}$ J. Hruschka, Verhaltensregeln..., s. 451. 
poczynionego przez ustanawiającego powinność, że dla adresata owa powinność jest możliwa do spełnienia ${ }^{45}$. Van Alphen wskazuje na reguły, które w praktyce mają ustalić znaczenie określonego faktu. Zasady te nie są oficjalnymi normami prawnymi, a jedynie mają charakter potencjalny ${ }^{46}$. $\mathrm{Z}$ tą odmianą zarachowania wiążą się następujące wyłączenia odpowiedzialności: (1) zasada impossibilium nulla est imputatio zakładająca, że sprawca nie miał fizycznej możliwości uniknięcia deliktu; (2) zasada necessariorum nulla est imputatio, czyli gdy sprawca znalazł się w sytuacji przymusu fizycznego bezwzględnego (vis absoluta); (3) zasada ignoratorum nulla est imputatio, gdy sprawca deliktu nie zdawał sobie sprawy, że istnieje możliwość alternatywnego zachowania ${ }^{47}$. Van Alphen zauważa, że ten typ zarachowania nie występuje u Kelsena ${ }^{48}$.

Zarachowanie drugiego stopnia implikuje zastosowanie systemu reguł zachowania w funkcji retrospektywnej i jest to sąd o winie sprawcy ${ }^{49}$. Jak wskazuje van Alphen, ten rodzaj zarachowania ściśle wiąże się z odpowiedzialnością ${ }^{50}$. Również tutaj pojawia się pojęcie wolności działania sprawcy, jednak w zupełnie innym kontekście. Już nie chodzi o fakt, że sprawca miał alternatywę, tylko o świadomość, że popełniony czyn jest niezgodny z prawem i nic nie stało na przeszkodzie, by określonej reguły postępowania nie naruszać ${ }^{51}$. Właśnie tę postać zarachowania ma na myśli Kelsen ${ }^{52}$. Błąd co do tego, że zachowanie jest nakazane lub zakazane, jest okolicznością usprawiedliwiającą. Ta przesłanka jest analogiczna wobec zasady ignoratorum nulla est imputatio. Drugą taką okolicznością, analogiczną wobec zasady impossibilium et necessariorum nulla est imputatio, jest ciężkie położenie (Notlage), w którym naruszenie określonej reguły to mniejsze zło, ponieważ w obu przypadkach wolność sprawcy jest mocno ograniczona ${ }^{53}$.

Jak trafnie podsumowuje van Alphen, zarachowanie pierwszego i drugiego stopnia to dwa kroki. Pierwszy z nich jest zmianą pewnej zaszłości w fakt prawny, natomiast drugi zmianą faktu prawnego w zachowanie ${ }^{54}$. Hruschka podsumowuje, że w tych podziałach widoczny jest słynny trzystopniowy schemat deliktów: stan faktyczny (okoliczność rodząca odpowiedzialność) - bezprawność - wina. Dwa pierwsze poziomy dotyczą zarachowania pierwszego stopnia, natomiast poziom

\footnotetext{
${ }^{45}$ Ibidem, s. 452-453.

${ }^{46}$ E. van Alphen, Kelsen and..., s. 177.

47 J. Hruschka, Verhaltensregeln..., s. 454.

${ }^{48}$ E. van Alphen, Kelsen and..., s. 171.

49 J. Hruschka, Verhaltensregeln..., s. 455.

${ }^{50}$ E. van Alphen, Kelsen and..., s. 165.

51 J. Hruschka, Verhaltensregeln..., s. 455.

${ }_{52}$ E. van Alphen, Kelsen and ..., s. 171.

${ }^{53}$ Pojęcie „stanu wyższej konieczności” wręcz się samo przy tłumaczeniu nasuwa, jednak w niemieckim języku prawniczym stosuje się inny wyraz: „Notstand”. Z tego względu zasadnym wydaje się zastosować tłumaczenie dosłowne: „ciężkie położenie”.

${ }^{54}$ Ibidem, s. 172.
} 
trzeci, zarachowania stopnia drugiego ${ }^{55}$. Podział, mający związek z wcześniejszymi rozważaniami, odnosi się do zarachowania zwyczajnego (ordentlich) i nadzwyczajnego (außerordentlich). Zarachowanie zwyczajne ma miejsce wówczas, gdy wydający orzeczenie nie widzi żadnych powodów, aby nie zarachować czynu sprawcy. W przypadku zarachowania nadzwyczajnego taka okoliczność zachodzi, ale osoba orzekająca i tak zarachowuje czyn sprawcy, na przykład, gdy sprawca własnym działaniem doprowadził do sytuacji błędu lub przymusu ${ }^{56}$.

W świetle powyższych rozważań tym, co wyraźnie daje się zauważyć, jest ścisłe powiązanie zarachowania w wersji klasycznej z odpowiedzialnością i powiązania go z normami indywidualnymi. Zarachowanie ma za zadanie odpowiedzieć na pytanie: „czy i kto jest odpowiedzialny za dany czyn?”. Jest linią łączącą dwa punkty: odpowiedzialnego i czyn (działanie lub zaniechanie), czy raczej - jak słusznie zauważyła Lübbe - nie tyle sam czyn, co możliwość określonego zachowania $^{57}$. Jeśli porównać koncepcję zarachowania klasycznego z konstrukcją kelsenowską, to widać, że sprowadza on zarachowanie wyłącznie do imputatio iuris, jako należące do sfery powinności.

\subsection{Zarachowanie, a przyczynowość - uwagi ogólne}

Skoro większość autorów wskazuje na analogię, jaka zachodzi pomiędzy zarachowaniem a przyczynowością, to zasadne jest postawienie pytania o relacje między nimi. W niniejszym fragmencie opisane zostanie to, co stanowi wspólną część dla poszczególnych faz. Kelsen zresztą raczej dużych zmian w tym zakresie nie wprowadzał.

Celem zarachowania jest odróżnienie przypadkowych zdarzeń od określonego czynu bezpośrednio powodującego następstwo opisane w prawie. Zarachowanie umożliwia odpowiedź na pytanie ,jak rozpoznać dane zdarzenie jako prawnie doniosłe?" ${ }^{58}$ Hruschka zauważa, że na każde zdarzenie można patrzeć z dwóch punktów widzenia: naturalistycznego oraz moralnego. O ile w pierwszym chodzi o prawdę, o tyle w drugim o sprawiedliwość ${ }^{59}$. Stwierdzenie to dość dobrze obrazuje konieczność istnienia zasady zarachowania. Podczas gdy powiązania przyczynowo-skutkowe umożliwiają dotarcie do prawdy, a zasada sine qua non zrównuje przyczyny, to na płaszczyźnie moralności i na płaszczyźnie prawnej te przyczyny już równorzędne nie będą, to jest jedne będą miały większą doniosłość od innych. Takie wyodrębnienie jest możliwe dzięki zasadzie zarachowania.

55 J. Hruschka, Verhaltensregeln..., s. 460.

56 Ibidem, s. 456.

57 W. Lübbe, Handeln, und Verursachen: Grenzen der Zurechnungsexpansion, [w:] W. Lübbe (Hrsg.), Kausalität und Zurechnung..., s. 224.

58 J. Hruschka, Strukturen ..., s. 4.

59 Ibidem, s. 9. 
Z kolei Kelsen obrał zupełnie inny punkt wyjścia i jest nim dualizm bytu i powinności. Jednym z najważniejszych pojęć w świecie powinności jest norma oraz zasada zarachowania ${ }^{60}$. Dualizm bytu i powinności to swego rodzaju lustrzane odbicie dualizmu zarachowania i przyczynowości. Wedle norm prawnych, gdy zdarzenie wyrażone w hipotezie normy ziści się, to na zasadzie zarachowania peryferyjnego musi zaistnieć następstwo przewidziane przez normę. Jednak już w świecie przyczynowości, następstwo może nie mieć miejsca z różnych względów; na przykład, gdy sprawca zdarzenia zmarł. Wówczas, opierając się na zasadzie przyczynowości, trzeba byłoby stwierdzić, że brak jest następstwa wyrażonego w hipotezie normy. Zatem drugą różnicą jest konieczność wystąpienia następstwa.

Renzikowski dopatruje się innej różnicy pomiędzy zarachowaniem a przyczynowością, wskazując, że zdania kauzalne podlegają falsyfikacji w przeciwieństwie do zdań normatywnych ${ }^{61}$. Wróblewski z kolei ujmuje tę różnicę jako odmienność między związkiem społecznym a przyrodniczym. Sankcja dotyczy osoby, wobec której jest to społecznie celowe. Wróblewski zauważa przy tym, że, że normatywista nie uznałby tego rozumowania, stwierdzając, iż jest to inny rodzaj zarachowania - prawno-polityczny, który opiera się na związkach odpowiedzialności i winy, podczas gdy rozważane jest zarachowanie prawno-teoretyczne dotyczące relacji między poprzednikiem i następnikiem normy prawnej62.

$\mathrm{Na}$ kolejne różnice wskazał Kelsen: po pierwsze, łańcuch powiązań przyczynowo-skutkowych jest nieskończony, natomiast zarachowanie ma swój punkt końcowy; po drugie, zarachowanie ma charakter normatywny, ponieważ związek pomiędzy bezprawiem a następstwem stanu niezgodnego z prawem ustanawiany jest przez kompetentny organ prawny. Zatem - $\mathrm{i}$ jest to kolejna różnica - zarachowanie jest uzależnione od określonego aktu woli, podczas gdy w przypadku przyczynowości brak jest takiej zależności63. Jak słusznie stwierdza Renzikowski, następstwo zachowania bezprawnego jest mu zarachowane, ale niekoniecznie przez nie spowodowane ${ }^{64}$. Kolejna różnica sprowadza się do stwierdzenia, że przyczynowość jest czymś dynamicznym. Dotyczy ruchu, zmiany w świecie rzeczywistym, zaś zarachowanie ma charakter statyczny. Dotyczy człowieka, nie jako istoty biologicznej, ale w znaczeniu normatywnym, czyli jako podmiot powinności, a tylko człowiek jako istota biologiczna może być rozpatrywana w aspekcie przyczynowości ${ }^{65}$.

Kelsen doprecyzowuje swoje stwierdzenie, pisząc, że rozdział między podmiotem a przedmiotem polega na tym, że nie musi między nimi istnieć żaden związek przyczynowy czy celowościowy. Nie musi, czyli jest możliwy, ale nie jest

${ }^{60}$ R. Pohlmann, Zurechnung und..., s. 87.

${ }_{61}$ J. Renzikowski, Der Begriff..., s. 259-260; zob. RR2, s. 80.

${ }^{6}$ J. Wróblewski, Krytyka normatywistycznej teorii państwa i prawa Hansa Kelsena, PWN, Warszawa 1955, s. 146.

${ }_{63}$ RR2, s. 93-94.

${ }^{64}$ Ibidem, s. 259-260.

${ }^{65}$ HP I, t. 1, s. 122. 
konieczny. Związek przyczynowy może naturalnie istnieć, ale nie ma z punktu widzenia normy większego znaczenia, ponieważ istnieje na poziomie treści normy, a nie jej formy.

To stwierdzenie pozwala na pobieżne wyjaśnienie problemu relacji zarachowania i przyczynowości jako przesłanki odpowiedzialności karnej i cywilnej w prawie polskim. W polskiej dogmatyce prawniczej pojęcie zarachowania nie jest rozpowszechnione. Zarówno w prawie karnym, jak i w prawie cywilnym ogólną przesłanką odpowiedzialności jest związek przyczynowy. Czy to oznacza, że zarachowanie można nim zastąpić? Kelsen udziela na to pytanie odpowiedzi przeczącej, zauważając, że pomiędzy podmiotem normy a jej przedmiotem nie musi być żadnych powiązań przyczynowych bądź celowościowych, co wskazuje na zupełny rozdział pomiędzy tymi elementami ${ }^{66}$. To zasada zarachowania dopiero decyduje na przykład o zasadzie winy bądź ryzyka. Na mocy zarachowania, w treści normy, można dopuścić jako przesłankę powiązania przyczynowo-skutkowe, ale wcale nie musi to być regułą. Treść tych norm jest już następnym etapem. Kelsen zajmował się tylko ich formą, której jednym z elementów jest zarachowanie. Wskazuje on wręcz, że zasada przyczynowości jako taka nie ma większego znaczenia. Przyczynowość nie może być podstawą zarachowania, nie ma bowiem kryterium, które pozwoliłoby na wyodrębnienie z łańcucha powiązań tych dwóch najważniejszych. Ponadto, argumentuje Kelsen, skutek najczęściej nie jest efektem jednego łańcucha przyczyn, ale kilku, równorzędnych i w przypadku zaniechania w ogóle o przyczynowości mowy być nie może ${ }^{67}$. W sposób analogiczny Kelsen krytykuje próby powiązania zasady zarachowania z zasadą umyślności, twierdząc, że jeśli nawet podmiot zamierzał naruszyć prawo, to z punktu widzenia zarachowania jest to pozbawione znaczenia ${ }^{68}$. Skutek jest podmiotowi przypisany tylko dlatego, że ów podmiot powinien działać tak a nie inaczej (zarachowanie na korzyść) lub nie (zarachowanie na niekorzyść) ${ }^{69}$.

Innym ważnym problemem podejmowanym $\mathrm{w}$ doktrynie jest pytanie o rozsądne granice zarachowania w odniesieniu do skutków ${ }^{70}$. Nie jest to pytanie, którym zajmował się Kelsen, ale po części można znaleźć u niego odpowiedź. Kelsen wskazuje, że dla zarachowania nie da się stworzyć jakiegoś wspólnego mianowni$\mathrm{ka}$, stałej reguły pozwalającej na ustalenie relacji między podmiotem a przedmiotem, zasada zarachowania bowiem jest zmienna, zależy tylko i wyłącznie od treści normy ${ }^{71}$. Wydaje się, że zarachowanie jako należące do świata myśli, świata kultury jest czymś arbitralnym, relatywnym, zaś jego granice są ustalane każdorazowo inaczej w zależności od miejsca i czasu. W tym sensie zarachowanie właśnie jest dynamiczne i treściowo nieuchwytne.

${ }^{66}$ Ibideme, s. 120.

${ }^{67}$ Ibidem, s. 121.

${ }^{68}$ Kelsen jako przykład wskazuje tu przestępstwo z niedbalstwa.

${ }^{69}$ Ibidem, s. 122.

${ }^{70}$ W. Lübbe, Handeln, und..., s. 225.

${ }^{71}$ HP I, t. 1, s. 123. 
Obrazowo podsumowując, porównanie zarachowania w Kelsenowskim ujęciu i zarachowania klasycznego przypomina porównywanie jabłek z pomarańczami. Zarówno jabłka (zarachowanie Kelsena), jak i pomarańcze (zarachowanie klasyczne) są owocami, posiadają pewne cechy wspólne, ale jasne jest, że różnice są na tyle istotne, że żaden sprzedawca nie będzie ich wrzucał do jednego koszyka, tym bardziej że jabłka mogą różnić się między sobą kolorem i smakiem. W związku z tym, jeśli możliwa jest próba porównania zarachowania klasycznego z poszczególnymi rodzajami zarachowania z czystej teorii prawa, to może ona zostać podjęta wyłącznie z uwzględnieniem ewolucji poglądów Kelsena. W dalszej części przedstawiona zostanie analiza ewolucji tego pojęcia $\mathrm{W}$ sensie nadanym mu przez Kelsena i dobitnie wykazane, że dość daleko odbiega ono od swojego pierwowzoru. Kelsen praktycznie definiuje to pojęcie na nowo i nadając mu nowy, głębszy sens, zmienia jego funkcje, sprawiając, że trafia ono w tym zakresie z peryferii prawoznawstwa do samego jądra rozważań. Dzięki temu jest to koncepcja oryginalna, twórcza i bogata intelektualnie.

Na pytanie, czy zarachowanie jest koniecznym elementem czystej teorii prawa, można odpowiedzieć dopiero, gdy wyróżni się jego rodzaje i spełniane funkcje. Zarachowanie w wersji klasycznej, polegające na tym, że zarachowuje się dany czyn określonej osobie, jest potrzebne. $Z$ opisanych wyżej względów pojęcie przyczynowości nie jest wystarczające dla przypisania odpowiedzialności konkretnej osobie. Czym innym jest $\mathrm{i}$ inne funkcje spełnia zarachowanie w kelsenowskim ujęciu. Czy dla opisu nauki prawa jest niezbędne? Odpowiedź na to pytanie może zostać udzielona dopiero po dokonaniu jego analizy w kontekście kolejnych faz rozwoju czystej teorii prawa. 


\section{Rozdział IV \\ Zarachowanie w fazie krytycznego konstruktywizmu}

\subsection{Krytyczny konstruktywizm i jego słabe punkty}

Rozprawa habilitacyjna, którą Kelsen napisał w wieku zaledwie 30 lat, przyciągnęła sporo uwagi jako praca podważająca tezy najwybitniejszych, w owych czasach, filozofów prawa i według współczesnych godziła w tradycyjne założenia. Głównie zatem pojawiły się głosy krytyczne, aczkolwiek wielu aprobowało to podejście, szczególnie zwolennicy neokantyzmu, którzy dostrzegali w tym próbę przetłumaczenia transcendentalizmu na język prawa. Pierwsza faza naukowej aktywności Kelsena, nie bez przyczyny, została przez Paulsona nazwana krytycznym konstruktywizmem. Paulson wskazuje, że w naukach prawniczych pojęcie „konstrukcja” dotyczy procesu tworzenia koncepcji albo efektu tego procesu. Kelsen inspirował się dokonaniami takich filozofów prawa, jak: Carl F. von Gerber, Paul Laband, Georg Jellinek, tworzących jedną szkołę, którzy w ramach programu konstruktywistycznego postulowali, ogólnie mówiąc, redukcję prawa do jego logicznej formy, analizy pojęć prawnych, czyli konstrukcji prawnej ${ }^{1}$. Według Gabriela Nogueria Diasa, teoretyczno-prawna analiza owego nurtu sprowadzała się do odpowiedzi na trzy pytania: po pierwsze, co oznacza konstruktywizm w ramach jurysprudencji pojęciowej (Begriffjurisprudenz); po drugie, na czym polega jego metoda; po trzecie, jakie znaczenie ma konstruktywizm dla metodologii prawoznawstwa ${ }^{2}$.

Najkrócej rzecz ujmując, metoda rekonstrukcyjna polega na logicznym uporządkowaniu „surowego" materiału prawnego, czyli norm prawnych, zwyczajów i innych źródeł prawa, dzięki czemu można go rozpatrywać jako system prawa³. Pomimo tego, że Kelsen przyswoił pewne elementy koncepcji wyżej wymienionych filozofów, to jednak do innych części odnosił się krytycznie, zarzucając, że wprowadzone zostały do nich elementy naturalizmu i psychologizmu, a sama próba oczyszczenia teorii prawa z elementów obcych nie do końca była udana. Kelsen kontynuuje program konstruktywistyczny w znacznie szerszym zakresie

${ }^{1}$ S.L. Paulson, Hans Kelsen's Earliest Legal Theory: Critical Constructivism, „Modern Law Review” 1996, vol. 59, s. 799-800; idem, Konstruktivismus, Methodendualismus und Zurechnung im Frühwerk Hans Kelsens, „Archiv des öffentlichen Rechts“ 1999, Bd. 124, s. 631.

${ }^{2}$ G.N. Dias, Rechtspositivismus und Rechtstheorie, Mohr Steinbeck, Tübingen 2005, s. 69.

3 Ibidem, s. 70. 
niż jego poprzednicy, wzbogacając go o elementy neokantowskie, przez co właśnie faza ta została przez Paulsona nazwana krytycznym konstruktywizmem ${ }^{4}$. Kelsen odwołuje się w nim do tradycji jurydyczno-naukowej, wprowadzając jednak silny dualizm bytu i powinności oraz konstrukcję zarachowania centralnego (będącego alternatywą dla tradycyjnej koncepcji osoby prawnej) $)^{5}$. Silne zaakcentowanie owego dualizmu doprowadziło do konkluzji o istnieniu dwóch zupełnie od siebie niezależnych i kompletnie oddzielonych sfer: bytu i powinności, których nie da się w żaden satysfakcjonujący sposób zdefiniować ${ }^{6}$ Za pomocą dualizmu Kelsen rozprawia się również z dogmatem woli w prawie cywilnym. Dokonuje dość przekonująco swego rodzaju przewrotu kopernikańskiego poprzez wskazanie, że zasadą nie jest stwierdzenie, że jeśli coś jest aktem woli, to jest obowiązujące z punktu widzenia prawa, ale odwrotnie - coś jest obowiązujące z punktu widzenia prawa, zatem jest aktem woli. Zabieg ten pozwala na abstrahowanie od psychologicznych konotacji pojęcia woli, dzięki czemu powstało rozróżnienie na wolę w psychologicznym i prawnym znaczeniu. W ten sposób wprowadzenie elementu woli do rozważań w żadnym stopniu nie narusza dualizmu bytu i powinności ${ }^{7}$.

Jak wskazuje Paulson, pierwotna koncepcja Kelsena posiada braki w wielu miejscach, na przykład w przypadku końcowego punktu zarachowania czy braku odpowiedzi na pytanie, dlaczego prawo obowiązuje ${ }^{8}$. W rezultacie Kelsen miał przykładowo problemy z poradzeniem sobie z wyjaśnieniem desuetudo. Radykalny rozdział bytu od powinności zmusił go również do wykluczenia pewnych zjawisk mających miejsce na gruncie prawa i arbitralne stwierdzenia, że nie mają one charakteru prawnego. Kelsen w HP pisze:

podobnie jak pytania o powstaniu i ustaniu rzeczywistości nie mogą znaleźć nigdy odpowiedzi w naukach eksplikatywnych, wykraczają bowiem w dziedzinę metafizyki, tak zagadnienia powstania i ustania prawa nie znajdą wytłumaczenia na płaszczyźnie normatywnej, są bowiem, jak to słusznie określił Jerzy Jellinek, natury pozaprawnej .

${ }^{4}$ S.L. Paulson, Hans Kelsen's..., s. 800-801; idem, Konstruktivismus ..., s. 638; R. Pohlmann, Zurechnung und Kausalität, „Rechtstheorie“ 1985, Bd. 5, s. 85-86; należy zwrócić uwagę, że przy ogólnym opisie założeń teorii Kelsena Pohlmann często powołuje się na przedmowę do wydania II, co nie do końca jest prawidłowe ze względu na to, że przedmowa pochodzi z roku 1923 i zaliczana jest do fazy drugiej, odwołującej się już bezpośrednio do kantyzmu i neokantyzmu. W HP takich bezpośrednich odwołań jeszcze nie ma, aczkolwiek widoczne są bardzo silne analogie, szczególnie do konstrukcji H. Cohena.

5 S.L. Paulson, Hans Kelsen 's..., s. 798; idem, Konstruktivismus..., s. 639-644.

${ }^{6}$ S.L. Paulson, Hans Kelsen 's..., s. 802.

7 Ibidem, s. 803-804; S.L. Paulson, Toward a Periodisation of the Pure Theory of Law, [w:] L. Gianformaggio (ed.), Hans Kelsen's Legal Theory a Diachotonic Point of View, G. Giappichelli Editore 1990, s. 26; idem, Konstruktivismus..., s. 642-644. Przy czym, zjawisko zgodne z opisanym w normie stanem rzeczy nie jest spełnieniem powinności wynikającej z tej normy. Ono się po prostu z normą zgadza.

${ }^{8}$ S. Paulson, Toward..., s. 31-33.

9 Ibidem, s. 95. 
Jednak to właśnie teza normatywna zaimplementowana na gruncie koncepcji pozytywistycznej była przełomowym pomysłem, tym co zwróciło oczy teoretyków i filozofów prawa w kierunku młodego naukowca, którym był wtedy Kelsen.

\subsection{Dualizm bytu i powinności}

Dla Kelsena zagadnienie bytu i powinności stanowi punkt wyjścia. Są to „dwa królestwa, których nie łączy żadna droga" 10 , pojęcia pierwotne, których zdefiniować się nie da. Te dwa odmienne sposoby myślenia mogą wprawdzie wynikać ze wspólnego założenia, ale nie czyni ich to zależnymi od siebie, ponieważ brak jest konieczności przerodzenia się powinności w rzeczywistość ${ }^{11}$.

Już na pierwszych stronach HP problem ten zostaje wyjaśniony poprzez rozróżnienie dwóch sposobów użycia wyrażenia „,prawo”: jako prawo przyrody, którego zadaniem jest objaśnienie rzeczywistości, oraz jako prawo z normatywnego punktu widzenia, które ustanawia powinność. Zadaniem norm nie jest ani opis, ani objaśnienie rzeczywistości. Stwierdzają one jedynie, że coś w ten a nie inny sposób dziać się powinno, zatem ich kryterium jest „ideał pewnego stanu rzeczy”" Jak wskazuje Heidemann, zagadnienie bytu i powinności pojawia się zarówno na płaszczyźnie ontologicznej, epistemologicznej, jak i logicznej (przy czym nacisk położony jest na aspekt ontologiczny) ${ }^{13}$. $Z$ ontologicznego punktu widzenia są to dwa różne światy, których uzasadnienia istnienia można szukać w tezie o niemożności wywiedzenia zdań powinnościowych ze zdań o bycie (płaszczyzna logiczna) $)^{14} \mathrm{i}$ które mają charakter niedefiniowalnych, pierwotnych ${ }^{15}$ kategorii oraz są wskazówkami badawczymi determinującymi badany stan rzeczy (płaszczyzna epistemologiczna). Powinność jest również rozpatrywana przez Kelsena jako idealna forma wypełniania realną treścią bytu ${ }^{16}$. Jej istota polega na tym, że ów idealny stan rzeczy, będący jej przedmiotem, nie musi stać się rzeczywistością, a jego urzeczywistnienie nie stanowi warunku konstytutywnego powinności ${ }^{17}$. Według Kelsena, powinność ma charakter relatywny, czyli obowiązuje tylko jako prawo pozytywne, nie czerpiąc swego uzasadnienia z etyki czy sprawiedliwości ${ }^{18}$.

${ }^{10}$ H. Kelsen, Die Rechtswissenschaft als Norm-oder als Kulturwissenschaft, [w:] H. Klecatsky, R. Marcic, H. Schambeck (Hrsg.), Die Wiener Rechttheoretische Schule, Europa Verlag Wien Frankfurt Zürich, Universitätsverlag Anton Pustet, Salzburg, München 1968, s. 38.

${ }^{11}$ HP I, t. 1, s. 49-50.

12 Ibidem, s. 45-48.

${ }^{13}$ C. Heidemann, Die Norm als Tatsache. Zur Normentheorie Hans Kelsen, Nomos Verlagsgesellschaft, Baden-Baden 1997, s. 24-28.

${ }_{14}$ HP I, t. 1, s. 50.

15 Ibidem, s. 49.

${ }^{16}$ C. Heidemann, Die Norm als..., s. 24-28.

${ }^{17}$ HP I, t. 1, s. 50.

${ }^{18}$ H. Kelsen, Die Rechtswissenschaft als..., s. 79. 
Interesująco $\mathrm{z}$ tego punktu widzenia zarysowują się relacje pomiędzy wolą a powinnością. Ogólnie rzecz ujmując, wola należy do sfery bytu ${ }^{19}$. Jak zauważa Heidemann, istnieją jednak dwa przypadki, gdy wola może być treścią powinności: po pierwsze, gdy wola ustanawia powinne wymaganie (Sollanforderung), po drugie, gdy wola skierowana jest na powinne wymaganie ${ }^{20}$. W pierwszym przypadku według Heidemanna chodzi o sytuacje, w których powinność określonego stanu rzeczy wynika z procesów wolicjonalnych, w drugim przypadku, gdy wola jest skierowana na czyjeś konkretne, powinne zachowanie. Zawsze jednak będzie istniało silne rozgraniczenie na wolę i powinność, co dość dobrze uwidacznia się w przytoczonym przez Kelsena zdaniu: „Chcę abyś... i dlatego powinieneś...”. Powinność może trwać, mimo że wola jej istnienia dawno zanikła ${ }^{21}$. To rozgraniczenie słabiej jest widoczne w przypadku norm moralnych, gdzie zarówno twórca powinności, jak i jej adresat często jest tą samą osobą, jednak według Kelsena nie ma wątpliwości, że oba momenty i tak łatwo rozgraniczyć22.

Według Heidemanna, tym, co obrazuje relację między powinnością a wolą, jest wartość. Kelsen ujmuje ją w subiektywnym i obiektywnym znaczeniu. W tym pierwszym, wartość jest funkcją woli albo środkiem, albo celem, do którego się dąży ze względu na wolę. Należy zatem do sfery faktów, w przeciwieństwie do wartości w znaczeniu obiektywnym, w której zawarty jest sąd o wartości lub jej braku w odniesieniu do określonej normy (czyli zgodności pewnego stanu faktycznego z normą prawną) $)^{23}$.

\subsection{Norma prawna}

W fazie krytycznego konstruktywizmu Kelsen zadaje pytanie: jak odróżnić normę prawną od innych norm czy stanów rzeczy. W celu udzielenia na nie odpowiedzi najpierw wskazuje, jakimi kryteriami posługiwanie się byłoby chybione ${ }^{24}$ : Po pierwsze, według Kelsena, nie da się normy rozpoznać za pomocą kryterium językowego. Nie ma w języku wyrażeń, które przesądzałyby, co jest normą prawną, a co nie, ponieważ „w użytych w tekście słowach nie tkwi bynajmniej immamentna ich moc stanowienia pewnej powinności"25. Po drugie, takim kryterium nie może być fakt ustanowienia ich przez odpowiednią władzę, wówczas bowiem należałoby odpowiedzieć na pytanie, jaka władza jest tą odpowiednią. Odpowiedź

${ }^{19}$ HP I, t. 1, s. 52.

${ }^{20}$ C. Heidemann, Die Norm als..., s. 27.

${ }^{21}$ HP I, t. 1, s. 52.

22 Ibidem, s. 53.

${ }^{23}$ C. Heidemann, Die Norm als..., s. 29-30; H. Kelsen, Podstawowe zagadnienia..., t. 1 , s. 113 .

${ }^{24}$ HP I, t. 1, s. 117-118.

${ }^{25}$ Ibidem, s. 117. Warto tu przypomnieć, że jest to praca z 1911 r. Pragmatyką zaczęto się interesować dopiero w drugiej połowie XX w. 
nieuchronnie musiałaby brzmieć, że można ją rozpoznać po zdolności stanowienia powinności, co skutkowałoby popadnięciem w błędne koło. Po trzecie, istotą normy nie może być cel, dla którego została stworzona, ponieważ ujęcie teleologiczne doprowadziłoby do potraktowania normy jako jednego z ogniw związku przyczynowo-skutkowego ${ }^{26}$. Byłoby to zatem równie błędne jak badanie norm w kategoriach przyczynowych. Ostatecznie, Kelsen definiuje normę prawną jako: „zdanie hipotetyczne (warunkowe) zawierające wolę państwa skierowaną ku własnemu zachowaniu”27. Przy czym, pojęcie „zdania hipotetycznego" i „sądu” są stosowane przez Kelsena zamiennie. Heidemann wyjaśnia w tym kontekście, że zdanie prawne dlatego nazywane jest sądem, ponieważ zawiera wyartykułowanie woli państwa dotyczącej określonego zachowania. Jest to sąd hipotetyczny, ponieważ wola państwa jest powiązana z określonymi warunkami ${ }^{28}$. Takie zdanie prawne zostałoby sformułowane w następujący sposób:

W określonych okolicznościach państwo ma wolę zachowywania się w określony sposób ${ }^{29}$.

Heidemann zwraca uwagę, że takie zdanie prawne nie brzmi jak zdanie powinnościowe, tylko zdanie oznajmujące ${ }^{30}$. Kelsen, według Heidemanna, rozwiązuje ten problem, stwierdzając, że owemu zdaniu nie można przypisać ani prawdy, ani fałszu, a więc ustanawia ono powinność, zaś jego formą jest norma ${ }^{31}$. Według Heidemanna, mimo że na pierwszy rzut oka Kelsen sformułowań „norma prawna” i „zdane prawne” używa zamiennie, to zdanie prawne utożsamiane jest raczej z konkretną powinnością niż z normą. Zdanie prawne istnieje tylko w postaci normy, ale może być prawdziwe lub fałszywe w zależności od tego, czy odpowiadająca mu wola państwa powstaje czy nie ${ }^{32}$. Inaczej nieco do tego problemu podchodzi Hendrik J. van Eikema Hommes, który analizując definicję normy prawnej jako hipotetycznego zdania, dochodzi do wniosku, że pojęcie „zdanie” jest tu użyte w sensie logicznym, w którym powinność oznacza predykat, zaś norma jest przez Kelsena zwana również zdaniem prawnym ${ }^{33}$. Wydaje się jednak, że propozycja van Eikema Hommesa zbyt upraszcza problem.

${ }^{26} \mathrm{O}$ ile do badania istoty normy takie ujęcie może być nieprzydatne, o tyle ujmowanie jej jako ogniwa związku przyczynowo-skutkowego nie wydaje się niczym błędnym. Norma m.in. takim ogniwem jest, co zresztą Kelsen przyznaje.

27 Ibidem, s. 25.

${ }^{28}$ C. Heidemann, Die Norm als..., s. 38.

${ }^{29}$ Ibidem.

${ }^{30}$ Ibidem.

31 Ibidem.

${ }^{32}$ C. Heidemann, Hans Kelsens Theorie normativer Erkenntnis, [w:] A. Brockmöller, D. Buchwald, D.V.D. Pfordten, K. Tappe (eds), Ethische und Strukturelle Herausforderungen des Rechts, Franz Steiner Verlag, Stuttgart 1997, s. 141.

${ }^{33}$ H.J van Eikema Hommes, The Development of Hans Kelsen's Concept of Legal Norm, Rechtstheorie, Duncker Humblot, Berlin 1984, s. 162. 
W przytoczonej definicji zabrakło jednego ważnego elementu normy prawnej, którym jest przymus. Nie oznacza to, że ów element został przez Kelsena pominięty. Zwraca on uwagę, że dla normy prawnej dopiero naruszenie dyspozycji powoduje jej zastosowanie i wtedy właśnie najdobitniej widoczny jest fakt jej obowiązywania ${ }^{34}$. Istotą normy jest zatem sankcja. Heidemann w tym kontekście zauważa, że Kelsen postrzegał ją w tej fazie jako „konkretną powinność”, pewną abstrakcyjną całość, która pochodzi od podmiotu normy, łącznika „powinien” oraz przedmiotu normy. Istnienie normy w takim układzie przejawia się w jej obowiązywaniu.

Jak wskazuje Heidemann, nie jest do końca jasne, jaką strukturę posiada norma prawna. Wiadomo, że można wyróżnić w niej dwa elementy: podmiot oraz przedmiot, które nie podlegają relacji związku przyczynowego. Jedyne powiązanie występujące między nimi ma charakter formalny i wyrażone jest przez słowo „powinien”. Oba elementy są przez ów łącznik ukonstytuowane i dzięki niemu nabierają normatywnego charakteru ${ }^{35}$. Heidemann wskazuje na wątpliwości, czy łącznik jest zarachowaniem. Próba odpowiedzi na to pytanie zostanie podjęta poniżej przy okazji wyjaśniania definicji zarachowania.

\subsection{Zarachowanie}

W pierwszej fazie widoczne jest, że Kelsen nie dopracował terminologii swojej teorii, co w dużym stopniu dotknęło konstrukcji zarachowania. Na przykład, pisząc na temat zarachowania na obowiązek i na prawo, rozpatruje je wobec człowieka, podczas gdy podmiotem w konstrukcji zarachowania rozpatrywanego w kontekście teorii prawa jest państwo. Istota ludzka jest w niej jedynie punktem zarachowania. Te rozważania należy zatem potraktować jako dotyczące zarachowania w ogólnym tego słowa znaczeniu. Odnoszą się one nie tylko do zarachowania prawnego, ale przede wszystkim zarachowania w sferze moralności, a nawet dotykają tematyki zarachowania gospodarczego. Powodem, dla którego zostały przedstawione w niniejszym rozdziale, jest to, że są charakterystyczne dla opisywanej fazy, przy okazji obrazując proces konstrukcji i konkretyzacji pojęcia zarachowania w czystej teorii prawa.

\subsubsection{Zarachowanie na obowiązek i zarachowanie na prawo}

Podział na zarachowanie na obowiązek i zarachowanie na prawo wynika ze spostrzeżenia, że zarachowanie gospodarcze musi odnosić się do jakiejś normy. Kelsen bada zagadnienie, czy w dziedzinie ekonomii zarachowanie ma miej-

\footnotetext{
${ }^{34}$ HP I, t. 1, s. 97.

${ }^{35}$ C. Heidemann, Die Norm als..., s. 29-30; HP I, t. 1, s. 118.
} 
sce i czy sprowadza się do tego samego co zarachowanie prawne i to dotyczące moralności. Zarachowanie gospodarcze swój rodowód wywodzi z nauki socjalistycznej, a konkretnie powiązane jest z pytaniem, w jaki sposób należy dokonać podziału dochodu pomiędzy ziemię, kapitał i pracę ${ }^{36}$. Jako przykład zarachowania na prawo Kelsen podaje zdanie: ,robotnik powinien otrzymać pełen dochód z pracy”, natomiast przykładem zarachowania na obowiązek jest zdanie: „,̇ołnierz powinien być dzielny”37. W każdym z tych zdań słowo „powinien”, w odniesieniu do podmiotu powinności (robotnik, żołnierz) zostało użyte w innym znaczeniu jako kolejno: prawo i obowiązek. Zarachowanie na prawo ustanawia obowiązek dla całego społeczeństwa, aby dokonała się taka dystrybucja dóbr i by zapewnić robotnikowi cały dochód z pracy oraz zakaz, by dochód ten nie został robotnikowi odebrany. Kelsen dalej zauważa, że prawo jest charakteryzowane w ten sposób: uprawnieniu jednego podmiotu towarzyszy (jest korelatem) obowiązek innego podmiotu. Ich przedmiot natomiast jest zarazem przedmiotem normy, obowiązku i prawa ${ }^{38}$. Wniosek, który się nasuwa, jest następujący: zarachowanie na prawo wynika z tej samej normy co zarachowanie na obowiązek, gdzie istnieją dwie kategorie podmiotów: podmiot zewnętrzny (podmiot, którego dotyczy obowiązek) oraz podmiot wewnętrzny (podmiot uprawniony) ${ }^{39}$.

Kelsen wskazuje, że związek pomiędzy zobowiązanym a uprawnionym jest wtórny wobec związku między podmiotem a przedmiotem obowiązku ${ }^{40}$. Związek ten również jest związkiem normatywnym polegającym na tym, że jeśli ktoś jest do czegoś uprawnionym, to temu uprawnieniu odpowiada obowiązek drugiej strony. Jako przykład Kelsen podaje prawo własności. Składa się na nie uprawnienie właściciela oraz obowiązek innych do powstrzymywania się od naruszeń. Najczęściej zobowiązanym (podmiotem zewnętrznym) będzie społeczeństwo ${ }^{41}$. Kelsen wskazuje, że zarachowanie na prawo, gdzie w przykładzie z robotnikiem będzie to zarachowanie na rzecz pracy, nie jest nielogiczne, ponieważ jest to jedynie kwestia stylizacji językowej, gdzie zarachowanie na pracę jest ekwiwalentne z pewnym stanem faktycznym ${ }^{42}$.

\subsubsection{Zarachowanie centralne jako operator powinnościowy}

Jedną z podstaw czystej teorii prawa w pierwszej fazie jest konstrukcja zarachowania, które później Kelsen nazwał „centralnym”, aby odróżnić je od zarachowania peryferyjnego. W niniejszym rozdziale, w celu zachowania klarowności

\footnotetext{
${ }^{36}$ HP I, t. 1, s. 126-128.

37 Ibidem, s. 128.

38 Ibideme, s. 130.

39 Ibidem, s. 129.

40 Ibidem.

${ }^{41}$ Ibidem, s. 130.

42 Ibidem.
} 
wywodu, zastosowana zostanie również terminologia z fazy neokantowskiej. Dokonując bliższej analizy, można zauważyć, że Kelsen nie był do końca konsekwentny w definiowaniu zarachowania. Pomijając wyżej opisane zarachowanie na obowiązek i na prawo, przypominające w swej strukturze zarachowanie klasyczne, Kelsen najpierw określa przypuszczalnie zarachowanie jako:

związek między poszczególnymi elementami normy, jaki wytwarza gramatyczne znaczenie słowa „powinność"43.

Warto tu zwrócić uwagę, że istnieje również wątpliwość, czy owa pierwsza definicja w ogóle dotyczy zarachowania. Kelsen, pisząc o tym powiązaniu, zarachowaniem go nie nazywa. Za przyjęciem, że jednak tak jest, świadczy sama konstrukcja pojęcia ${ }^{44}$. Co więcej, to właśnie do tej definicji najprawdopodobniej odnosi się wątpliwość Heidemanna, czy Kelsen uwzględnia tu zarachowanie peryferyjne.

Kilka akapitów dalej Kelsen podaje drugą definicję zarachowania:

związek między pewnym stanem faktycznym, a podmiotem, ustalony na płaszczyźnie wytworzonej przez normę jest zarachowaniem pewnego działania, pewnej zaszłości na pewien podmiot ${ }^{45}$.

wskazując przy tym, że zarachowanie to:

swoiste i od pojęcia przyczynowości i celowości różne i niezależne logiczne powiązanie elementów normy.

Joachim Renzikowski wskazuje, że te dwa ujęcia nie dotyczą tego samego, pierwsza definicja bowiem odnosi się do połączenia warunku i następstwa, zaś druga do podmiotu i przedmiotu normy ${ }^{46}$. Interpretacja Renzikowskiego jednak nie musi być prawidłowa. Jak wiadomo, Heidemann w tych dwóch elementach upatruje właśnie podmiotu i przedmiotu normy. Sam Kelsen zresztą w następnym zdaniu stwierdza:

W treści normy, w gramatycznym tego słowa znaczeniu, odróżnić należy dwa elementy, dwie części składowe, a to podmiot powinności, to jest to, na czem powinność ciąży, a więc osobę, do której norma jest skierowana - oraz przedmiot powinności, to jest to, co ma być spełnione, co obowiązuje ${ }^{47}$.

${ }^{43}$ Ibidem, s. 118.

${ }^{44}$ Zob. C. Heidemann, Die Norm als..., s. 29-30.

45 Ibidem, s. 119.

46 J. Renzikowski, Der Begriff der „Zurechnung” in der Reinen Rechtslehre Hans Kelsens, [w:] R. Alexy, L.H. Meyer, S.L. Paulson, G. Sprenger (Hrsg.), Neukantianismus und Rechtphilosophie, Nomos Verlagsgesellschaft, Baden-Baden 2002, s. 254.

${ }^{47}$ HP I, t. 1, s. 118. 
W kontekście HP taka ogólna definicja zarachowania lepiej by się wpasowywała w rozważania na temat zarachowania centralnego, jednak wyłącznie pod warunkiem, że Kelsen miał na myśli te same elementy. Na pierwszy rzut oka wydawać się może, że tak jest. Mamy podmiot i stan rzeczy, który można by utożsamiać ze wspomnianym wcześniej przedmiotem. Kluczowym stwierdzeniem tutaj jest „na płaszczyźnie wytworzonej przez normę”, dzięki czemu Kelsen „domyka” swój system. Zarachowanie jest - tak jak inne elementy jego teorii - zamknięte w świecie powinności, czyli jak dalej stwierdza Kelsen: „można je określić jako normatywne"48. Jednak nieco inną interpretację tej definicji proponuje Heidemann. Według niego zarachowanie z pierwszej definicji jest łącznikiem między zdarzeniem mającym miejsce w rzeczywistości (które odpowiada lub nie hipotezie normy) oraz podmiotem normy ${ }^{49}$. W takim wypadku istniałaby zasadnicza różnica między zarachowaniem z pierwszej definicji a drugiej. W pierwszej zarachowanie wiąże to, co normatywne, z tym, co rzeczywiste. Jest łącznikiem między bytem i powinnością, podczas gdy w schemacie drugim pozostaje $\mathrm{w}$ obrębie normy. Wydaje się jednak, że można zaryzykować tezę, że obie definicje odnoszą się do tego samego rodzaju zarachowania. Zauważmy, że Kelsen, określając $w$ pierwszej definicji, co jest przedmiotem, pisze o tym, co ma być spełnione, co obowiązuje. Te sformułowania wskazują raczej na normatywny aspekt. Heidemanna mogło zmylić następne zdanie, w którym Kelsen pisze o zastosowaniu normy do zjawisk rzeczywistych. Moim zdaniem jest to nowa myśl nie mająca bezpośredniego związku ze strukturą zarachowania

Na poparcie tej tezy można przytoczyć słowa Kelsena z przedmowy do drugiego wydania HP:

Jako odpowiednik kauzalnych powiązań występujących w naturze uznałem w „Podstawowych pojęciach...” zarachowanie. Tak jak wcześniej, na stronie 71, muszę je sformułować jako powiązanie, które powstaje pomiędzy elementami znajdującymi się wewnątrz zdań prawnych, takie powiązanie, które gramatycznie zostaje stworzone poprzez słowo ,powinien” ${ }^{50}$.

Wydaje się, że przytoczony fragment nie pozostawia wątpliwości odnośnie do dwóch definicji zarachowania, przesądzając, że tak naprawdę Kelsen definiował zarachowanie $\mathrm{w}$ jeden sposób. Jednak w tym miejscu pojawia się inny problem: przedmowa do drugiego wydania HP to manifest fazy neokantowskiej, więc można przypuszczać, że w tym miejscu Kelsen miał już na myśli zarachowanie peryferyjne. Wówczas sytuacja się komplikuje jeszcze bardziej, gdy zauważymy, że pierwsza definicja zarachowania również do złudzenia przypomina zarachowanie peryferyjne. Wydaje się jednak, że pisząc pracę habilitacyjną, Kelsen miał dość jasną wizję, czym jest zarachowanie. Jak już wykazałam wcześniej, obie

\footnotetext{
${ }^{48}$ Ibideme, s. 119.

49 C. Heidemann, Die Norm als..., s. 31.

${ }^{50}$ HP II, s. IX.
} 
definicje dotyczą tego samego zarachowania - później nazwanego centralnym. Takie były reguły gry językowej w pierwszej fazie. Gdy w drugiej fazie powstała nowa gra językowa, zmieniło się rozumienie zarachowania (doszło zarachowanie peryferyjne), mimo że jego definicja pozostała prawie bez zmian.

Na tym jednak sprawa się nie kończy, w dalszych częściach książki bowiem Kelsen przytacza jeszcze inne sformułowania definicji zarachowania, które przemawiają za wspomnianą wcześniej interpretacją Heidemanna. Kelsen definiuje zarachowanie jako ,powiązanie podmiotów z zewnętrznymi zaszłościami, dokonane na zasadzie norm prawnych" ${ }^{51}$ i wskazuje, że zarachowanie „wiąże pewną zewnętrzną zaszłość z pewną jednostką" "52. Te dwa cytaty są raczej rozstrzygające. W pierwszej fazie Kelsen przytoczył dwie definicje zarachowania. Pierwsza z nich nie przekracza granic powinności, a zarachowanie ma charakter czysto normatywny, natomiast druga, odwołująca się do wyżej przytoczonych dwóch ostatnich cytatów, raczej wskazuje na zarachowanie jako łącznik pomiędzy tym co faktyczne, a tym co normatywne. Mało tego, tutaj pojawia się problem, jaką osobę Kelsen ma na myśli? Bo jeśli konkretną (a skoro pisze o jednostce, to pewnie tak), to kelsenowska konstrukcja takiego zarachowania obejmuje założenie, że łączy ono dwa elementy należące do sfery faktów. Taka interpretacja wydaje się jednak silnie uderzać w podstawową dla Kelsena tezę o dualizmie bytu i powinności. Skoro zarachowanie łączy pewien stan faktyczny z podmiotem normy prawnej, to czy nie jest tak, że tym samym dualizm zostaje przełamany. Problemu tego nie ma przy pierwszej interpretacji, gdy Kelsen nadaje zarachowaniu normatywny charakter, argumentując, że powstało ono na płaszczyźnie stworzonej przez normę $e^{53}$.

$\mathrm{Na}$ koniec warto poruszyć jeszcze jeden problem: w poprzednim rozdziale stwierdzono, że Kelsenowskie zarachowanie, jako należące do sfery powinności, to imputatio iuris. W świetle poczynionych rozważań warto jednak zadać pytanie, czy faktycznie zarachowanie centralne przybiera taki właśnie charakter, czy może jest to raczej imputatio plena. Jeśli jednak rozpatrywać zarachowanie centralne jako ,powiązanie podmiotów z zewnętrznymi zaszłościami na zasadzie norm prawnych”, to należy stwierdzić, że ostatni człon tej definicji („,na zasadzie norm prawnych") wskazuje, że chodzi tu jednak o imputatio iuris.

\subsubsection{Zarachowanie a osobowość prawna}

Mimo poczynionych wyjaśnień terminologicznych, wydaje się, że przedstawiona powyżej definicja zarachowania centralnego nadal brzmi nieco tajemniczo. Aby wyjaśnić sens tego pojęcia, warto przyjrzeć się mu w konfiguracji z innymi elementami czystej teorii prawa. Jednym $\mathrm{z}$ nich jest pojęcie woli $\mathrm{w}$ znaczeniu

\footnotetext{
${ }^{51}$ HP I, t. 1, s. 196.

52 Ibidem.

${ }^{53}$ Ibidem, s. 118.
} 
prawnym. W przeciwieństwie do woli w znaczeniu psychologicznym należy ona do sfery powinności. Na wstępie Kelsen stwierdza, że prawo jest wolą państwa ${ }^{54}$. Wola w prawnym znaczeniu jest konstytuowana przez normy prawne w myśl założenia, że skoro jakaś norma obowiązuje, to była przedmiotem woli określonego podmiotu ${ }^{55}$. Taka konstrukcja nie jest faktem, tylko założeniem koniecznym dla celów zarachowania, ponieważ ze względu na istniejącą normę prawną istnieje jedynie możliwość zarachowania określonego zachowania będącego przedmiotem woli. Owo stanowisko Kelsen wyraża w dość stanowczy sposób:

Trzeba sobie uprzytomnić, że określenie „wytwarzanie woli państwowej” jest wyłącznie obrazowe. [...] Konstrukcja sformułowana dla celów zarachowania, wspólny punkt zarachowania dla pewnych stanów rzeczy, nie może w ogóle powstać na drodze procesu przyczynowego, nie może „być wytworzony”, pomijając już, że samo państwo jako takie nie jest niczem innem, jak tym właśnie punktem zarachowania prawnego. Dla poglądu prawnego osoba i wola jest tożsamością ${ }^{56}$.

Dzięki temu koncepcja woli państwa w ujęciu psychologicznym zostaje zastąpiona poprzez konstrukcję końcowego punktu zarachowania. W ten sposób ponownie zostaje odwrócona perspektywa. Już nie: ,jeśli coś jest przedmiotem woli państwa, wówczas jest państwo zarachowane”, ale: ,jeśli coś państwu zarachowane, to znaczy, że jest przedmiotem jego woli”. W rezultacie wola państwa nie jest niczym innym jak antropomorfizującym wyrażeniem zastępującym słowo „powinien” ${ }^{57}$. Nie trudno zauważyć, że takie odwrócenie perspektywy umożliwia abstrahowanie od faktów. Wydaje się zatem, że ów sposób myślenia można zrekonstruować w następujący sposób: „skoro powstał określony akt prawny nakładający akt przymusu i jest w mocy, to znaczy, że należy zarachować go państwu". $\mathrm{Z}$ kolei, według Heidemanna, schemat takiej normy wyglądałby następująco:

\section{Pod warunkami x państwo ma wolę czynić y}

Jak trafnie ujął van Eikema Hommes, wola państwa jest myślową konstrukcją, ostatnim punktem, w którym zbiegają się wszystkie linie zarachowania. Innymi słowy, państwo ma wolę tego, co można mu zarachować58.

Wyjaśniając, na czym polega odmienność woli w prawnym tego słowa znaczeniu, Kelsen zwraca uwagę, że różnica jest widoczna nawet na poziomie językowym. Nie mówi się, że „to państwo głosuje w parlamencie” czy też, że to „państwo podpisuje ustawy”. Czym innym zatem jest wola w znaczeniu psychologicznym, którą można przypisać np. głosującym posłom czy prezydentowi, a czym innym wola w znaczeniu prawnym, przypisana państwu. Gdyby przyjąć

${ }^{54}$ Ibidem, t. 1, s. 145.

55 Ibidem, s. 184.

${ }^{56}$ Ibidem, t. 2, s. 113.

57 S. Paulson, Toward..., s. 27-28.

${ }^{58}$ H.J van Eikema Hommes, The Development..., s. 161-162; 
tożsamość woli państwa i organów procesu ustawodawczego, to można by dojść do wniosku, że wola państwa jest w sobie sprzeczna, na przykład w sytuacji, gdy prezydent korzysta z prawa veta wobec ustawy. Zarachowanie państwu natomiast byłoby niemożliwe ze względu na brak jednolitego punktu zarachowania ${ }^{59}$. Innymi słowy, $\mathrm{z}$ wolą $\mathrm{w}$ znaczeniu prawnym mamy do czynienia, jeśli można zarachować określonemu podmiotowi określony stan faktyczny. Jak wskazuje Heidemann, jest zatem wola państwa swego rodzaju końcowym punktem, do którego dążą wszystkie „linie” zarachowania, dzięki czemu państwo zapewnia jedność systemu prawa ${ }^{60}$.

Z pojęciem woli w znaczeniu prawnym wiąże się problem, na który zwrócił uwagę van Eikema Hommes, pytając, w jaki sposób psychiczny akt woli może nabrać cech normatywnych? ${ }^{61}$ Na pierwszy rzut oka wydaje się, że można odpowiedzieć na to pytanie, odwołując się do metafory lustra. Odbity obraz pochodzący z rzeczywistości w lustrze to świat powinności. Tak więc wola w psychologicznym znaczeniu ma swoje odbicie w lustrze jako wola w znaczeniu prawnym. Warto jednak zwrócić uwagę, że wola w znaczeniu prawnym szczególnie jako końcowy punkt zarachowania ma bardzo specyficzny charakter. Nie jest prostym przełożeniem woli psychologicznej, lecz jest punktem, do którego zmierza każda pojedyncza wola. Wydaje się zatem, że metafora lustra może odnosić się jedynie do pośrednich punktów zarachowania. Wola jako końcowy punkt zarachowania tej metaforze się wymyka.

Ważnym pojęciem w tym kontekście jest zasada zarachowania definiowana jako norma prawna:

która zawiera zasadę, że istnieje wola państwa do stworzenia wśród pewnych okoliczności określonego stanu rzeczy, który wyraża się przez stwierdzenie, że pewne działania pewnych osób mają uchodzić (należy zarachować), wśród ustalonych normą warunków, za działania państwa ${ }^{62}$.

Norma jest zatem regułą zarachowania, wskazuje bowiem pod jakimi warunkami można zarachować zachowanie państwu ${ }^{63}$. Kelsen zwraca uwagę, że w procesie ustawodawczym brak jest jednak norm wyrażających zasadę zarachowania, ponieważ taka norma musiałaby zawierać wolę państwa do tworzenia ustaw, czyli oznaczać pewną wolę, co prowadziłoby do absurdalnej konstrukcji „,woli woli”“4. Żeby uratować swoją teorię, Kelsen tak samo jak w przypadku desuetudo musi stwierdzić, że prawotwórstwo znajduje się „poza sferą pojęć prawnych”, będąc jedynie ich założeniem i przesłanką ${ }^{65}$. Owa „pozaprawna” działalność nie może

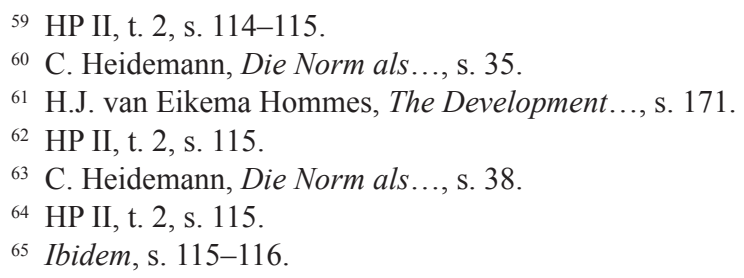


zostać zarachowana, gdyż brak jest tu wspomnianej reguły zarachowania, która może być wyrażona tylko w prawie pozytywnym ${ }^{66}$. Ostatecznie Kelsen dochodzi do absurdalnego na pierwszy rzut oka wniosku, że państwo nie jest twórcą ani porządku prawnego, ani żadnej należącej do niego normy prawnej ${ }^{67}$. Teza ta staje się jaśniejsza, gdy doda się do niej kelsenowskie stwierdzenie, że porządek prawny i państwo są ze sobą tożsame, choć rozpatruje się je z dwóch odmiennych punktów widzenia. Państwo jest przede wszystkim wolą w znaczeniu prawnym, natomiast porządek prawny zbiorem zdań hipotetycznych, czyli norm ${ }^{68}$. Wobec zabiegu wykluczenia zagadnień związanych z tworzeniem prawa poza prawoznawstwo, można przywołać zarzuty już podniesione podczas analizy problemu desuetudo, przede wszystkim zarzut wskazujący, że Kelsen popełnia błąd petitio principii, uznając podstawy swojej teorii, jak dualizm bytu i powinności czy też koncepcję woli za pewnik, podczas gdy istnieją poważne wątpliwości co do tych założeń. Ponadto, wszelkie elementy, które mogłyby ów „pewnik” obalić, Kelsen eliminuje poprzez stwierdzenie, że nie jest to problem prawny. Taka eliminacja pomaga dodatkowo udzielić odpowiedzi na pytanie: o jakie działania państwa może tutaj chodzić? Skoro wykluczone zostały te o charakterze prawotwórczym, to wydaje się, że pozostają przede wszystkim kompetencje związane z przymusowym charakterem porządku prawnego. Można zatem zaryzykować stwierdzenie, że w ten sposób, dzięki zarachowaniu możliwe jest zidentyfikowanie określonych działań jako będących przedmiotem woli i podjętych przez państwo. Jest to tym samym odpowiedź na pytanie: w jaki sposób odróżnić bandę rozbójników dokonujących aktu przymusu od działań państwa.

Za takim ujęciem opowiada się Paulson. Według niego punkt zarachowania ma spełniać rolę identyfikatora prawa, ewentualnie być kryterium jego obowiązywania. Należy się tu ponownie odwołać do słynnego kelsenowskiego pytania, jak materiał prawny jest możliwy do poznania jako prawo. Według twórcy HP, jest to możliwe ze względu na istniejący w prawie punkt odniesienia, jakim jest punkt zarachowania. Dzięki punktowi zarachowania określony materiał (na przykład rozporządzenie) może być postrzegany jako materiał prawny. Jednak w przypadku określonego punktu zarachowania, który umożliwił taką identyfikację rozporządzenia, również zachodzi pytanie, czy należy on do systemu prawa. Odpowiedzi należy szukać w kolejnym punkcie zarachowania ${ }^{69}$. Uwagi Paulsona należy uznać za jak najbardziej słuszne, jednak należy również wykazać czujność, gdy pisze on o „identyfikacji rozporządzenia”. Skoro bowiem Kelsen wszelkie problemy związane z tworzeniem prawa odrzucił, jako niemogące być

${ }^{66}$ Ibidem, s. 141, 179.

${ }^{67}$ Ibidem, s. 143.

${ }^{68}$ Ibidem.

${ }^{69}$ S.L. Paulson, Die Zurechnung als apriorische Kategorie in der Rechtslehre Hans Kelsens, [w:] M. Kaufmann, J. Renzikowski (Hrsg.), Zurechnung als Operationaliesierung von Verantwortung, Peter Lang, New York 2004, s. 101; idem, Konstruktivismus..., s. 645-646. 
przedmiotem prawoznawstwa, to czy zarachowanie centralne w pierwszej fazie faktycznie może pomóc w identyfikacji rozporządzenia? Wydaje się, że można udzielić na to odpowiedzi twierdzącej. Jeśli za punkt wyjścia obierze się akt przymusu, to szukając jego podstaw, w łańcuchu kolejnych punktów zarachowania, natrafi się w końcu na owo symboliczne rozporządzenie. Jednak należy podkreślić w tej fazie, że nie ma jeszcze bezpośredniego powiązania typu: „można zarachować ustanowienie tego rozporządzenia państwu". Warto jednak zauważyć, że jest to konstrukcja wymuszona, przecząca intuicji, która nakazywałaby, przy takiej definicji zarachowania centralnego, powiązanie go z procesem prawotwórczym.

Z konstrukcji woli w znaczeniu prawnym, według Kelsena, wynika również, że nie można państwu zarachować zaniechania, gdyż prowadziłoby to do konkluzji, że niczego się państwu nie zarachowuje, a zatem nie może być mowy o istnieniu woli prawnej. Zobowiązanie państwa do zaniechania pozbawione jest znaczenia również dlatego, że już sam brak określonej normy prawnej ustanawiającej obowiązek działania czyni niemożliwym działanie, którego państwo ma zaniechać. Jest to uzasadnione tym, że państwo może podejmować działania wyłącznie będące przedmiotem swej woli i poza ten zakres wykroczyć w żaden sposób nie może ${ }^{70}$. Takie postawienie sprawy oznacza również, że jeśli dany organ podejmuje działanie mimo braku normy prawnej (będącej regułą zarachowania), która do niego zobowiązuje, to nie można tego działania zarachować państwu oraz stanowi ono naruszenie obowiązku tego organu ${ }^{71}$. Z rozważań dotyczących woli w znaczeniu prawnym wynika, że przedmiotem woli państwa mogą być tylko te zachowania wyrażone w ustawie, które zostały państwu zarachowane.

Podsumowując, zarachowanie centralne posiada dużą doniosłość w rozważaniach dotyczących istoty państwa. Państwo wpierw wyraża swoją wolę będącą końcowym punktem zarachowania (wyrażonej w sformułowaniu „powinien”), którego treścią jest stan rzeczy oraz państwo samo jest adresatem tej powinności. W pewnym sensie państwo występuje w dwóch rolach: po pierwsze, jako to, którego wola jest punktem zarachowania (powinność), oraz po drugie, jako podmiot, który znajduje się w relacji do określonego stanu rzeczy. Poprzez ten zabieg Kelsen omija pułapkę, którą byłoby uwikłanie się w psychologiczne ujęcia woli.

Należy przy tym zwrócić uwagę, że pisząc o państwie jako końcowym punkcie, Kelsen nie ma na myśli określonego organu państwowego, który ma urzeczywistnić określoną normę (zasadę zarachowania) ${ }^{72}$. Jak wskazuje Kelsen, zarachowanie działań organów przechodzi przez poszczególne punkty, którymi są konkretne osoby (sfera bytu), do „pomyślanego poza nimi punktu”’3, którym jest państwo. Takie ujęcie, według Kelsena, prowadzi do wyłączenia ze sfery rozważań osoby, która działa w imieniu organu. Organ jest zatem jedynie przechodnim

\footnotetext{
70 S.L. Paulson, Die Zurechnung als..., s. 146.

71 Ibidem, s. 149.

${ }^{72}$ Ibidem, s. 246.

73 HP II, t. 2, s. 246.
} 
punktem zarachowania i w przeciwieństwie do państwa nie ma woli. Państwo natomiast działa przez swoje organy ${ }^{74}$. W tym miejscu Kelsen dokonuje ważnego rozróżnienia, wskazując, że w stosunku do zasady zarachowania jedynym podmiotem mającym osobowość prawną jest państwo. Jednak nie wyklucza to stwierdzenia, że każdy podmiot, a w szczególności organ z punktu widzenia swoich urzędowych obowiązków, posiada osobowość prawną, ponieważ w tym przypadku nie znajduje się w relacji z regułą zarachowania ustanawiającą obowiązek państwa (przez niego urzeczywistniany). Organ jest zatem osobą prawną wobec normy, w której treści można znaleźć konkretne obowiązki służbowe ${ }^{75}$. Przy takim ujęciu pojawia się zaś pytanie, co z pozostałymi podmiotami uczestniczącymi w obrocie prawnym. Człowiek staje się osobą w znaczeniu prawnym właśnie poprzez możliwość zarachowania wobec niego. Innymi słowy, to zarachowanie „sprawia”, że człowiek może podlegać normom. Samo zarachowanie, według Kelsena, nie musi dotyczyć wyłącznie ludzi. Wynika to z charakteru normy prawnej, która może odnosić się do czegoś innego niż człowiek (np. dotyczyć osób prawnych $)^{76}$. Ponadto, zarachowanie określonej osobie pewnego stanu rzeczy, czyniąc ją za niego odpowiedzialną, nie musi oznaczać, że ten stan rzeczy musiał być spowodowany akurat przez ten podmiot ${ }^{77}$. Stwierdzenie, że zarachowanie centralne dotyczy zachowań, to za mało, ponieważ przedmiotem zarachowania centralnego jest pewna całość: osoba ${ }^{78}$. Zachowanie jest dla zarachowania tylko punktem przejściowym, zaś punktem końcowym wola w znaczeniu normatywnym. To oznacza również, że jest to ostatni punkt zarachowania, pomimo tego, że na zasadzie przyczynowości można się posunąć nieskończenie dalej. W punkcie tym człowiek zostanie poprzez zarachowanie wyrwany z łańcucha przyczynowo-skutkowego ${ }^{79}$.

Wola w znaczeniu etyczno-prawnym jest identyczna z całą jednością, za jaką uchodzi jednostka w dziedzinie etyki lub prawa. Zdolność woli i zdolność osobowości prawnej, tj. zdolność stania się podmiotem etycznego lub prawnego zarachowania, są pojęciami równoważnymi ${ }^{80}$.

Zatem Kelsen, jak wskazuje Paulson, nie chcąc się wikłać w rozważania prawno- naturalne, co byłoby konieczne, gdyby zaakceptował tradycyjnie przyjętą definicję zarachowania, odnoszącą się nie tylko do prawa, ale i do moralności, musiał zrezygnować z osoby fizycznej jako możliwego podmiotu prawa. Podobnie był zmuszony postąpić z konstrukcją osoby prawnej, zastępując ją pojęciem poszczególnych punktów zarachowania. Ostatecznie, jak już wiadomo, przyjął

${ }^{74}$ Ibidem.

75 Ibidem, s. 246-247.

${ }^{76}$ Ibidem, t. 1, s. 130-131.

77 Ibidem, s. 196.

78 Ibidem, s. 196-197.

${ }^{79}$ Ibidem, s. 197, 212.

${ }^{80}$ Ibidem, s. 198. 
rozwiązanie, w którym zarachowanie (jako punkt zarachowania) wiąże się z innym zarachowaniem ${ }^{81}$. O ile pierwszy krok eliminacji osoby fizycznej jest w pełni uzasadniony, to drugi jawi się jako bardziej problematyczny. Kelsen podaje dwa powody takiej konstrukcji: po pierwsze, nie chce się narazić na zarzut, że do swojej teorii wprowadził czynnik oparty na fikcji; po drugie: stara się w ten sposób uniknąć antropomorfizacji osoby prawnej. Według Paulsona, jednak i z tego punktu widzenia rodzą się problemy. Z jednej strony należy uznać, że istnieje połączenie treściowe pomiędzy światem rzeczywistości oraz światem wartości, szczególnie w kontekście konstrukcji obowiązku prawnego (gdy się uzna, że jego treścią może być tylko ludzkie zachowanie), a z drugiej, dualizm bytu i powinności wymusza przyjęcie, że między tymi dwoma porządkami nie może być żadnych punktów stycznych. Kelsen jednak podtrzymywał swoje radykalne stanowisko o rozdziale bytu i powinności również w fazie neokantowskiej, utrzymując, że nie może być żadnego związku między człowiekiem a punktem zarachowania ${ }^{82}$.

Podsumowując za Paulsonem, punkty zarachowania reprezentujące część systemu prawa, odnoszą się do innych punktów zarachowania na bardziej podstawowym poziomie. W końcu dochodzi się do poziomu, gdzie punkt zarachowania dotyczy całego systemu prawa i jest końcowym punktem zarachowania. Oznacza to, że system prawny jako ostateczny punkt zachowania musi implikować, założyć z góry sam siebie. Według Paulsona, to rozumowanie niesie błąd petitio principii, ponieważ skoro dochodzi się do wniosku, że system prawa musi założyć sam siebie, to na nowo należy zadać pytanie, jakie są podstawy tej konstrukcji ${ }^{83}$. Innymi słowy, skoro istnieje końcowy punkt zarachowania, to co stanowi dla niego podstawę? Gdzie jest ugruntowanie całego porządku prawnego? Ten problem doprowadził Kelsena do wprowadzenia do swojej teorii normy podstawowej oraz uwzględnienia problemu hierarchicznej struktury prawa.

\subsubsection{Zarachowanie a celowość i przyczynowość}

W HP Kelsen poświęcił dość sporo uwagi relacjom między przyczynowością a zarachowaniem. W kolejnych publikacjach ograniczał się (z reguły) do skrótowego zarysowania tych różnic, niekiedy dodając jakiś nowy element. Warto zatem przyjrzeć się tej analizie wiedeńskiego filozofa prawa.

Jak już wcześniej wspomniano, normę prawną Kelsen definiuje jako zdanie hipotetyczne, zdecydowanie odrzucając tym samym teorię imperatywu. W normie znajduje się powiązanie hipotetycznego stanu rzeczy z jego następstwem. O ile $\mathrm{w}$ przyrodzie następstwo pewnego stanu rzeczy powstaje w wyniku powiązań

${ }^{81}$ S.L. Paulson Die Zurechnung als..., s. 100; idem, Konstruktivismus ..., s. 649.

82 S.L. Paulson, Hans Kelsen 's..., s. 809; idem, Konstruktivismus..., s. 649.

${ }^{83}$ S.L. Paulson, Hans Kelsen's..., s. 808; idem, Die Zurechnung als..., s. 101-102; idem, Konstruktivismus..., s. 650-651. 
przyczynowo-skutkowych (,jeżeli istnieje A, to musi istnieć B”), o tyle w przypadku normy prawnej mamy do czynienia z zarachowaniem (,jeżeli istnieje $\mathrm{A}$, to powinno istnieć B"). Twórca czystej teorii prawa uznał zarachowanie za szczególną właściwość prawa i tak jak łączy się konieczność (byt) z przyczynowością, tak połączył zarachowanie z pojęciem powinności. Jak wskazuje Clemens Jabloner, analogię pomiędzy zarachowaniem a związkiem przyczynowym należy rozumieć $\mathrm{w}$ ten sposób, że o ile powiązania przyczynowe są formą praw natury, o tyle zarachowanie jest formą normy prawnej ${ }^{84}$. Zarachowanie może pokrywać się ze związkiem przyczynowo-skutkowym, ale nie musi (na przykład przy odpowiedzialności za cudze czyny). Jabloner trafnie zauważa, że o ile zarachowanie w zdaniach prawnych pełni podobną funkcję do funkcji pełnionej przez związek przyczynowo-skutkowy, zdaniach dotyczących sfery bytu, o tyle jako powiązanie ma zupełnie inne znaczenie. Powstaje na mocy aktu woli odpowiedniego organu państwa, podczas gdy powiązania przyczynowe są niezależne ${ }^{85}$.

Dla Kelsena zasada przyczynowości nie mogła znaleźć zastosowania z dwóch względów. Po pierwsze, trudno wskazać kryterium, które rozstrzygałoby, którą z nieskończonego łańcucha przyczyn wziąć pod uwagę, a którą nie. Kelsen przyznaje, że możliwa jest sytuacja, że zarachowanie „biegnie po linii równoległej do związku przyczynowego" ${ }^{86}$ wtedy, gdy zarachowanie jest łącznikiem między dwoma ogniwami łańcucha przyczynowego, jednak nie oznacza to, że podstawą zarachowania jest związek przyczynowy. Nie da się za jego pomocą dokonać wyboru dwóch ogniw spośród wielu rozstrzygających o zarachowaniu. Ponadto, argumentuje Kelsen, tak naprawdę każdy skutek jest rezultatem nie jednego łańcucha przyczyn, ale wielu ${ }^{87}$. Po drugie, niemożliwe jest stwierdzenie występowania powiązań przyczynowo-skutkowych w przypadku zaniechania, ponieważ za przyczynę można uznać jakąś zmianę aktywności, a nie jej brak ${ }^{88}$. Brak aktywności oznacza, że przyczyną pewnego stanu rzeczy jest nie ten łańcuch powiązań, tylko szereg innych, w których określone zmiany czy też określone aktywności doprowadziły do takiego, a nie innego skutku. Zarachowanie natomiast jest w pewnym sensie pasywne. Ma miejsce w stosunku do czegoś „,w spoczynku”, czyli człowieka w sensie podmiotu prawnego jako podmiotu powinności ${ }^{89}$. Człowiek w sensie biologicznym jest aktywny, swoim działaniem zmienia rzeczywistość, w odróżnieniu od człowieka w sensie normatywnym, będącym konstrukcją

${ }^{84}$ C. Jabloner, Beiträge zur einer Sozialgeschichte der Denkformen: Kelsen und die Einheitswissenschaft, [w:] C. Jabloner, F. Stadler (Hrsg.), Logische Empirismus und Reine Rechtslehre; Beziehungen zwischen dem Wiener Kreis und der Hans Kelsens-Schule, Veröffentlichungen des Instituts Wiener Kreis Springer, Wien, New York 2001, s. 37.

${ }^{85}$ Ibidem, s. 23-24.

${ }^{86}$ HP I, t. 1, s. 120.

${ }^{87}$ Ibidem, s. 121.

${ }^{88}$ Ibidem, s. 122.

${ }^{89}$ Ibidem. 
prawną. Zarachowanie jest niezależne również od zasady celowości, choć i ten element może istnieć w samej zasadzie zarachowania.

Kelsen krytykuje w związku z tym podnoszony argument, że w dziedzinie moralności wyłączną podstawą zarachowania może być zasada celowości. Według niego, takie ujęcie uzależnia zarachowanie od tego, czy przedmiot zachowania jest wynikiem woli podmiotu, co da się uzasadnić wyłącznie poprzez założenie pewnej fikcji. Zarachowanie w moralności może zatem odnosić się nie tylko do działań, ale również do ich skutków oraz skutków zaniechania, które nie mają nic wspólnego z zasadą przyczynowości. Jeśli byłoby inaczej, to zarachowanie byłoby niedopuszczalne w sytuacji, w której wystąpiłby inny skutek niż ten wolą zamierzony ${ }^{90}$. Wydaje się jednak, że aby rzetelnie rozstrzygnąc tę kwestię, należałoby wpierw wyraźnie zdefiniować, na czym polegają zasady moralności, oraz rolę, jaką w niej odgrywają intencje. Kelsen swoje stanowisko uzasadnia tym, że w przypadku zarachowania chodzi o to, czy określony skutek powinien być przewidziany, nie zaś, czy był przewidziany. Jako przykład wskazuje on na sytuację niedotrzymania przyrzeczenia. Ten, kto chcąc go dotrzymać, zapomina o nim, również zasługuje na ujemną ocenę moralną ${ }^{91}$. Wydaje się, że o ile ta teza doskonale współgra $\mathrm{z}$ konstrukcją norm prawnych, to w dziedzinie moralności może zawodzić, rodzi się bowiem wątpliwość, czy przy takiej definicji zarachowania może być w ogóle o nim mowa. Niedotrzymanie przyrzeczenia być może jest przykładem wspierającym kelsenowską tezę, ale nie należy zapominać, że istnieją przypadki, gdy ktoś mimo dobrych intencji wywołał negatywny skutek, choć dołożył wszelkiej staranności, by tak się nie stało (na przykład ktoś nie dotrzymał ważnego przyrzeczenia, ponieważ miał wypadek i trafił do szpitala). Wydaje się, że w przypadku moralności celowość ma pierwszorzędne znaczenie. Jednak należy podkreślić, że Kelsen miałby rację, jeśli znajdzie się choć jeden przypadek negatywnej oceny moralnej bez oglądania się na intencje danej osoby, ponieważ to by oznaczało, że zasada zarachowania może również być inna niż ta opierająca się na celowości. Kelsen konkluduje, że:

Zarachowanie pewnego stanu rzeczy ma miejsce, gdy stan ten, względnie jego przeciwieństwo, jest powinnością z normy wynikającą, a nie z powodu, że było treścią woli podmiotu. Zasadę zarachowania należy bowiem dedukować $\mathrm{z}$ treści normy, a nie z aktu psychicznego (woli) podmiotu zarachowania $^{92}$.

Warto zauważyć, że zarachowanie centralne stoi w nieco innej relacji do przyczynowości aniżeli zarachowanie klasyczne. Z tego względu najpierw zostanie dokonana próba porównania zarachowania klasycznego z centralnym, aby odpowiedzieć na pytanie, na ile analogia między przyczynowością a zarachowaniem centralnym jest możliwa.

\footnotetext{
${ }^{90}$ Ibidem, s. 122-126.

${ }^{91}$ Ibidem, s. 124.

92 Ibidem.
} 
W przypadku zarachowania klasycznego sprawa wydaje się dość prosta. Różnicę w powiązaniach zarachowania klasycznego i związku przyczynowo-skutkowego można wyjaśnić poprzez odwołanie się do rozróżnienia między osobą sprawcy a odpowiedzialnego, które nie muszą być ze sobą tożsame. Odpowiedzialnym może być inna osoba niż sprawca czynu. Stąd wniosek, że po pierwsze, nie jest to powiązanie o charakterze przyczynowo-skutkowym, po drugie, owo powiązanie ma charakter normatywny. Gdy jednak jednym z elementów zarachowania jest państwo, tak proste odniesienie nie jest możliwe. Punktem wspólnym zarachowania centralnego i klasycznego są na pierwszy rzut oka łączone elementy - jednym z nich w obu wypadkach jest podmiot, a drugim stan faktyczny, który temu podmiotowi się zarachowuje. Na tym jednak podobieństwa się kończą. Podmiotem w konstrukcji zarachowania centralnego jest przede wszystkim państwo, natomiast zarachowania klasycznego - osoba fizyczna lub prawna. Państwu zarachowywany jest pewien powinny stan rzeczy, podczas gdy zarachowanie klasyczne przypisuje podmiotowi stan rzeczy, aby uczynić go odpowiedzialnym. Widać tu, że obie operacje dokonywane są na innych poziomach. Przy zarachowaniu centralnym chodzi o zachowanie będące przedmiotem obowiązku, natomiast przy zarachowaniu klasycznym o zachowanie, będące przedmiotem odpowiedzialności. Wskazane różnice ilustruje tabela 2.

Tabela 2. Różnice między zarachowaniem klasycznym a centralnym

\begin{tabular}{|c|c|c|}
\hline Rodzaj zarachowana & Podmiot & Przedmiot \\
\hline Klasyczne & Osoba fizyczna lub prawna & Odpowiedzialność \\
\hline Centralne & Państwo & Powinne zachowanie \\
\hline
\end{tabular}

Źródło: opracowanie własne.

Hans J. Sandkühler trafnie to podsumowuje, stwierdzając, że w tradycyjnym zarachowaniu chodzi o to, jak ktoś się zachował, natomiast u Kelsena jak ktoś zachować się powinien ${ }^{93}$. Wracając do relacji między przyczynowością a zarachowaniem centralnym, wydaje się, że Kelsen nie do końca jasno thumaczy tę analogię. Porównując zarachowanie centralne i przyczynowość, poprzestaje na ogólnikach, nie podaje konkretnych przykładów. Ewentualnie podaje różnice ogólnie między przyczynowością a zarachowaniem i powody, dla których przyczynowość nie może być rozpatrywana w odniesieniu do norm. O ile można stwierdzić dość bliskie pokrewieństwo między zarachowaniem klasycznym a przyczynowością, na przykład, gdy dziecko, wyrządziło szkodę (przyczynowość),

${ }^{93}$ H.J. Sandkühler, „Natur" des Rechts und Relativismus in Recht. Eine Studie zu Gustav Radbruch und Hans Kelsen im Kontext Neukantianismus, [w:] R. Alexy, L.M. Meyer, S.L. Paulson, G. Sprenger (Hrsg.), Neukantianismus und Rechtphilosophie, Nomos Verlagsgesellschaft, Baden-Baden 2002, s. 140. 
a odpowiedzialność za wyrządzoną szkodę ponosi rodzic (zarachowanie), to owo pokrewieństwo staje się mniej czytelne w przypadku zarachowania centralnego. Wydaje się, że można tu zaproponować następujący przykład: organ państwowy wydał określoną decyzję (związek przyczynowo-skutkowy), powinne zachowanie (wydanie decyzji) zostało zarachowane państwu (zarachowanie).

\subsection{Podsumowanie}

Z dokonanej analizy pojęcia zarachowania w fazie krytycznego konstruktywizmu wynika, że nie było ono przez Kelsena w pełni dookreślone. Analiza tekstu rozprawy habilitacyjnej rzuca podejrzenie, że Kelsen nawet nie był świadom, że używa pojęcia zarachowania w kilku znaczeniach i definiuje na różne sposoby. Raczej wygląda na to, że posługiwał się jednym pojęciem zarachowania i w zależności od kontekstu nadawał mu odpowiednią treść. Owo uchybienie zanika jednak w kolejnych fazach, w których Kelsen wprowadza w tym zakresie reżim terminologiczny. Ponadto, wydaje się, że konstrukcja zarachowania centralnego w tym kształcie, w którym pojawiła się w kelsenowskiej teorii, została wymuszona przez takie a nie inne założenia metodologiczne. Dzięki niej, czysta teoria prawa jawi się niewątpliwie jako koncepcja ciekawa i oryginalna. Z drugiej jednak strony, zarachowanie centralne, w szczególności, w kontekście rozważań państwa jako końcowego punktu zarachowania razi pewną sztucznością. Kolejnym mankamentem wydają się związki zarachowania z bytem. Skoro łączy ono stan faktyczny i podmiot opisany w normie, to wszystko wskazuje na to, że jednocześnie zarachowanie w sposób zupełnie niezamierzony pełni funkcję łącznika pomiędzy bytem i powinnością, podważając główne założenie normatywizmu. Mając na uwadze, że wspomniana sztuczność konstrukcji jest właśnie rezultatem tezy o radykalnym odseparowaniu bytu od powinności, można wysnuć konkluzję, że ostatecznie w tym zakresie Kelsenowi nie udało się stworzyć spójnej koncepcji i słusznie została ona w następnych fazach przeformułowana. 


\section{Rozdzial V Zarachowanie w fazie neokantowskiej}

Faza neokantowska jest najszerzej znana i omawiana w doktrynie. Heidemann twierdzi, że teoria z tego okresu jest „najbardziej wyrafinowaną teorią poznania prawnego, którą Kelsen kiedykolwiek przedstawil"'. To w niej pojawiają się najsłynniejsze pojęcia, z którymi teoria Kelsena jest powszechnie identyfikowana: „norma podstawowa”, „dynamiczna struktura prawa” i ,zarachowanie peryferyjne". O ile przedmowa do wydania II HP może być uznana za jeden z pierwszych wyraźnych sygnałów, że poglądy Kelsena uległy zmianie, to za najważniejszą pracę w tej fazie uważa się wydanie pierwsze Czystej teorii prawa z roku 1934. Hartney parafrazując Kanta nazwał je ,prolegomeną do wszelkiej nauki prawnej, jeśli ma być naukowa"². Zagadnienie dotyczące wpływów neokantowskich u Kelsena nie jest jednak tak oczywiste, jakby się na pierwszy rzut oka wydawało. Po pierwsze, Kelsen nawiązuje do kantowskiej epistemologii, a nie, jak można by się spodziewać do Metafizyki moralności. Wynika to z faktu, że Kelsen postrzegał praktyczną filozofię Kanta jako „najdoskonalszy (vollkommenste) wyraz klasycznej nauki prawa natury"3. Po drugie, w odniesieniu do neokantyzmu wyraźnie powołuje się on na Hermana Cohena, jednak jak wskazuje Zajadło: „Kelsen formalnie należał do szkoły marburskiej, ale w jego filozofii widać też silne wpływy kierunku heidelberskiego"4. Kelsen był zatem zarówno pod bardzo silnym wpływem Kanta (w zakresie „krytyki czystego rozumu”), jak i jego uczniów, w szczególności Szkoły Marburskiej oraz Szkoły Badeńskiej5.

${ }^{1}$ C. Heidemann, Die Norm als Tatsache. Zur Normentheorie Hans Kelsen, Nomos Verlagsgesellschaft, Baden-Baden 1997, s. 43.

2 M. Hartney, Introduction: The Final Form of the Pure Theory of Law, [w:] H. Kelsen, General Theory of Norms, trans. Michael Hartney, Clarendon Press, Oxford 1991, s. XX.

${ }^{3}$ H. Kelsen, Die philosophischen Grundlagen der Naturrechtslehre und des Rechtspositivismus, [w:] H.R. Klecatsky, R. Marcic, H. Schambeck (Hrsg.), Die Wiener rechtstheoretische Schule, Europa Verlag Wien Frankfurt Zürich, Universitätsverlag Anton Pustet, Salzburg, München 1968, s. 286.

${ }^{4}$ J. Zajadło, Przedmowa do wydania polskiego, [w:] G. Radbruch, Filozofia prawa, Wydawnictwo Naukowe PWN, Warszawa 2009, s. XX.

${ }_{5}$ Zob. S.L. Paulson, Kelsen in Marburg School: Reconstructive and Historical Perspectives, [w:] W. Krawietz, N. MacCormick, G.H. von Wright (eds), Prespective Formality and Normative Rationality in Modern Legal Systems, Duncker Humblot, Berlin 1994; C. Heidemann, Geltung und Sollen: Einige (neu-)kantische Elemente der Reinen Rechtslehre Hans Kelsens, [w:] R. Alexy, L.H. Meyer, S.L. Paulson, G. Sprenger (Hrsg.), Neukantianismus und Rechtsphilosophie, Nomos Verlagsgesellschaft, Baden-Baden 2002, s. 205-212. 
Można zadać pytanie, skąd tak silne ciążenie ku zagadnieniom stricte filozoficznym. Wydaje się, że wynikało ono m.in. z identyfikacji słabych punktów teorii przedstawionej w HP i spostrzeżenia, że skoro Kelsen odrzuca zarówno tezę redukcyjną jak i tezę o związku, czyli dwie podstawy, skąd prawo mogłoby czerpać swe uzasadnienie dla obowiązywania (a więc i rację bytu), to musi zaproponować coś w zamian. Ową propozycją jest właśnie neokantyzm. Kwestia ta po części zostaje wyjaśniona w przedmowie do wydania II HP poprzez wskazanie, że pewnych odpowiedzi dotyczących prawa należy szukać w filozofii, stanowiącej fundament dla bardziej szczegółowych rozważań na temat prawa. Kelsen wydaje się twierdzić, że nie da się skonstruować teorii nie posiadając filozoficznego zaplecza:

Stwierdzenie istnienia związku między zasadniczymi konstrukcjami prawnymi, a pewnymi zasadami filozoficznego świata, uchyliłoby sprzeczności istniejące w rozbudowaniu tychże konstrukcji w różnych systemach prawnych, gdyż wspólne, ogólne zasady stanowiłyby linię wytycznej dla konstrukcji szczegółowych, w których myśl zasadnicza tylko się odbija ${ }^{6}$.

Co zatem Kelsen przejął od Kanta i neokantystów? Wcześniej wspomniane już zostało, że tak jak Kant stworzył syntezę dwóch wzajemnie się zwalczających poglądów (racjonalizmu oraz empiryzmu), Kelsen podjął próbę dokonania podobnej syntezy w odniesieniu do teorii prawa. Podobieństw jest zresztą znacznie więcej. Już nawet tytuł Czysta teoria prawa nawiązuje do Krytyki czystego rozumu Kanta. Sam twórca czystej teorii prawa wskazuje na wątki odwołujące się do dualizmów: rozumu praktycznego i teoretycznego, wartości i rzeczywistości oraz moralności i natury ${ }^{7}$ Wróblewski ujmuje rzecz nieco inaczej, wskazując na następujące elementy: pytanie ,jak możliwe jest poznanie prawne”, dualizm bytu i powinności, formalizm konstrukcji, konieczne założenia poznania prawnego i kompromis ideału społecznego ${ }^{8}$. Według jeszcze innego autora, Isaaka Dore’a, wątki kantowskie widoczne są tam, gdzie Kelsen mówi o czystości metodologicznej w odniesieniu do poznania prawa (polegającego właśnie na zastosowaniu kantowskiej metody) oraz gdy charakteryzuje naukę prawa ${ }^{9}$. Wydaje się, że Dore trafia w sedno, podając dość ogólną charakterystykę neokantowskich wątków pojawiających się w czystej teorii prawa. Elementy wymienione przez samego Kelsena i Wróblewskiego stanowią jej uszczegółowienie. Wymienione zagadnienia rzutują na inne pojęcia, na przykład normy prawnej czy zarachowania, które teraz przybierają kantowski lub neokantowski wydźwięk.

${ }^{6}$ HP I, t. 1, s. 18.

${ }^{7}$ HP II, s. VI.

8 J. Wróblewski, Krytyka normatywistycznejteorii prawa i państwa Hansa Kelsena, PWN, Warszawa 1955, s. 26; należy zauważyć, że wiele z tych elementów pojawiło się u Kelsena już wcześniej. Kelsen zainteresował się neokantyzmem po tym, jak zwrócono mu uwagę, że w jego rozprawie habilitacyjnej pojawia się wiele wątków podobnych do tych zawartych w teorii prawa Cohena.

${ }^{9}$ I.I. Dore, The Epistemological Foundations of Law, Carolina Academic Press, Durham 2007, s. 563. 


\subsection{Norma prawna}

Jak już wspomniano, w swoich publikacjach Kelsen niejednokrotnie podkreśla, iż normatywizm powstał na podstawie tego, co stworzył Kant i neokantyści ${ }^{10}$. Heidemann wskazuje, że Kelsen swoje założenia w fazie klasycznej opierał na kilku tezach przejętych od neokantystów: (1) nie ma rzeczy samej w sobie, (2) obiektywny świat jako przedmiot poznania jest poprzez poznanie konstruowany, (3) poznanie przejawia się wyłącznie poprzez ważne sądy, (4) punktem wyjścia krytyki poznania są obiektywne sądy nauk instrumentalnych, (5) nauki normatywne różnią się od teoretyczno-empirycznych nauk poprzez sposób, w jaki w ich sądach są stosowane kategorie ${ }^{11}$. Na tej podstawie Kelsen stwierdza, że obiektywna rzeczywistość jest zbudowana przez poznanie w taki sposób, że czyste pojęciowe kategorie łączą alogiczny materiał, dzięki czemu oparta na sądach nauka prawa jest możliwa. Ważność sądów wynika z tego, że korespondują z regułą poznania. W przypadku nauk przyrodniczych przedmiotem poznania są sądy naukowe, w których zostaje zastosowana kategoria przyczynowości. Podobnie sytuacja wygląda z naukami prawnymi, gdzie przedmiotem poznania jest system ważnych sądów dotyczących prawa, poprzez poprawne zastosowanie kategorii powinności ${ }^{12}$, będącej kategorią analogiczną wobec kategorii przyczynowości ${ }^{13}$. W związku z tym, zdania prawne (normy prawne) są hipotetycznymi sądami, w których dwa stany faktyczne są ze sobą powiązane za pomocą powinności ${ }^{14}$. Wpływy neokantowskie doprowadziły zatem do uwypuklenia znaczenia sądów. O ile w poprzedniej fazie sformułowanie to w odniesieniu do normy miało rolę raczej drugorzędną, o tyle uzyskawszy kantowskie (neokantowskie) zabarwienie, teraz jest jednym $z$ centralnych pojęć.

Czym zatem jest sąd? Heidemann wskazuje na trzy tezy, które można znaleźć u Kelsena na temat sądów: (1) sąd z jednej strony ma być rozumiany w kategoriach logicznych, jest czymś innym niż psychiczny akt zawarty w nim; (2) idealna egzystencja sądów ma miejsce w ich obowiązywaniu, którego wyrazem jest powinność; (3) sąd nie dotyczy określonego obiektu, lecz jest identyczny z obiektem poznania ${ }^{15}$.

${ }^{10}$ HP II, s. VI.

${ }^{11}$ C. Heidemann, Der Begriff der Zurechnung bei Hans Kelsen, [w:] S.L. Paulson, M. Stolleis (Hrsg.), Hans Kelsen Staatsrechtslehrer und Rechtstheoretiker des 20. Jahrhunderts, Mohr Siebeck, Tübingen 2005, s. 18.

${ }^{12}$ Lub zarachowania, ewentualnie normy podstawowej.

13 RR1, s. 33-35.

14 Ibidem, s. 34; C. Heidemann, Der Begriff..., s. 19-20.

15 C. Heidemann, Hans Kelsens Theorie normativer Erkenntnis, [w:] A. Brockmöller, D. Buchwald, D.V.D. Pfordten, K. Tappe (Hrsg.), Ethische und Strukturelle Herausforderungen des Rechts, Franz Steiner Verlag, Stuttgart 1997, s. 143; idem, Die Norm als..., s. 52-54. 
Te trzy przesłanki prowadzą Kelsena do stwierdzenia, że sąd, czyli zdanie prawne jest identyczne z normą prawną. Krótko mówiąc, podsumowuje Heidemann:

Obiektem nauki prawa jest prawo. Prawo powstaje z norm. Te nie są dane poznaniu prawnemu, ale w nim konstytuowane. $\mathrm{Z}$ tego względu obiekt poznania jest identyczny $\mathrm{z}$ sądem poznawczym, norma prawna jako obiekt nauki prawa nie jest niczym innym jak sąd nauki prawa dotyczący normy, czyli zdaniem prawnym ${ }^{16}$.

Zdanie prawne (norma prawna) jako hipotetyczny sąd (hipotetyczny, bo wyrażony $\mathrm{w}$ formie zdania warunkowego) składa się z warunku i następstwa powiązanych nie za pomocą przyczynowości, lecz zarachowania ${ }^{17}$. Przy takim ujęciu norma prawna nie jest podmiotowym imperatywem (który jako rozkaz musi mieć swojego adresata), lecz przedmiotowym zdaniem. Zabieg ten, twierdzi Kelsen, jest próbą uzasadnienia obiektywności obowiązywania prawa, a tym samym obiektywnego charakteru prawa w ogóle, które obowiązuje bez względu na jego znajomość $^{18}$. Jak wskazuje Hartney, normy prawne mają tę samą strukturę i funkcję, czyli są adresowane do kompetentnych organów, zobowiązując je do nałożenia sankcji w określonych okolicznościach. Oznacza to, że prawo jest zbiorem norm, których adresatami są organy państwowe umocowane do użycia przymusu. I dopiero $\mathrm{z}$ tego tytułu powstaje obowiązek prawny przestrzegania norm przez inne podmioty ${ }^{19}$. Hartney również zwraca uwagę na stwierdzenie Kelsena, że normy prawne będące zdaniami w swoim prawdziwym kształcie mogą być zrekonstruowane przez naukę prawa (i wtedy funkcjonują jako zdania prawne), co rodzi dwa pytania: po pierwsze, w jaki sposób normy prawne mogą być zdaniami (a to stwierdzenie prowadzi Kelsena do wniosku o możliwości zastosowania logiki do norm); po drugie, skoro powinność nie ma imperatywnego charakteru, to nie wiadomo, jaka ona jest ${ }^{20}$. Ponadto specyficzna egzystencja normy, którą jest obowiązywanie, również nie wyjaśnia wszystkiego. Na przykład nie do końca wiadomo, w jaki sposób rozumieć w tym kontekście twierdzenie, że norma ze względu na to, że nie jest obiektem naturalnym, obowiązuje poza czasem i przestrzenią ${ }^{21}$ (skoro w prawoznawstwie dobrze znany jest terytorialny i temporalny aspekt obowiązywania norm $)^{22}$. W tym miejscu być może wystarczy wyjaśnienie, że zarówno temporalny, jak i terytorialny aspekt obowiązywania uzależniony jest od treści norm. Jest zatem wobec norm wtórny. Gdy się od treści abstrahuje, to wydaje się zatem możliwe umieszczenie normy poza czasem i przestrzenią. Czy jednak

${ }^{16}$ C. Heidemann, Hans Kelsens Theorie..., s. 144.

17 RR1, s. 33-34; ASL, s. 54.

18 HP II, s. 54.

19 M. Hartney, Introduction..., s. 43-44.

20 Ibidem, s. XXIII.

${ }^{21}$ RR1, s. 21.

${ }^{22}$ M. Hartney, Introduction..., s. XXIV. 
wówczas nie wkracza się na tak krytykowane przez Kelsena pole metafizyki? Te pytania, mimo że interesujące nie są kluczowe dla czystej teorii prawa. Najistotniejsze w konstrukcji normy jest wprowadzone do niej zarachowanie peryferyjne, które zostanie teraz omówione.

\subsection{Zarachowanie peryferyjne}

Pojęcie zarachowania peryferyjnego, definiowanego jako normatywne połączenie dwóch stanów faktycznych (tatbestand) ${ }^{23}$, nabiera kształtu w przedmowie do drugiego wydania HP. Zarachowanie wiąże zatem warunek prawny z następstwem prawnym w taki sposób, że następstwo jest warunkowi zarachowane. Dzięki temu zostaje zapewniona autonomia nauk prawnych wobec nauk przyrodniczych ${ }^{24}$. Warto tę myśl rozwinąć i postawić pytanie: w jaki sposób zarachowanie gwarantuje autonomię nauk prawnych? Jak wskazuje Heidemann, ta niezależność może zostać zapewniona jedynie pod warunkiem, że nauka prawa będzie obiektywna, normatywna i pozytywistyczna. Warunek obiektywizmu jest niezbędny, aby w ogóle można było mówić o nauce. Obiektywizm zostaje zapewniony poprzez poprawne zastosowanie kategorii zarachowania w ważnym sądzie prawnym. Normatywność wiąże się z dualizmem bytu i powinności i tym samym wynika już z samej istoty zarachowania. Gwarancją pozytywności jest znowu kategoria zarachowania o charakterze czysto formalnym, abstrahująca od jakiejś z góry określonej treści, która mogłaby charakteryzować normy moralne ${ }^{25}$.

Zarachowanie peryferyjne pełni dwie podstawowe funkcje. Po pierwsze, jest logiczno-semantyczną zasadą, zwracającą uwagę na dwa różne użycia języka (w świecie bytu i powinności), normatywnym łącznikiem pomiędzy warunkiem oraz następstwem, wyrażonymi w normie prawnej. Innymi słowy, jest powiązaniem warunku zastosowania sankcji (zachowania niezgodnego z opisem wyrażonym w normie prawnej) oraz sankcją ${ }^{26}$. Po drugie, może spełniać funkcję relatywnej kategorii a priori, która jest wyznaczona przez powinność prawną. Ma wtedy charakter formalny i jest przesłanką argumentu transcendentalnego ${ }^{27}$. Obie funkcje zostaną omówione osobno.

${ }^{23}$ RR1, s. 34.

${ }^{24}$ ASL, s. 49; C. Heidemann, Der Begriff..., s. 19.

${ }^{25}$ C. Heidemann, Der Begriff..., s. 20.

26 S.L. Paulson, On the Kelsen - Kant Problematic, [w:] E.G. Valdèz, W. Krawietz, G.H. Von Wright, R. Zimmerling (Hrsg.), Normative Systems in Legal and Moral Theory, Duncker \& Humblot, Berlin 1997.

${ }^{27}$ Ibidem, s. 207; J. Renzikowski, Der Begriff der „Zurechnung” in der Reinen Rechtslehre Hans Kelsens, [w:] R. Alexy, L.H. Meyer, S.L. Paulson, G. Sprenger (Hrsg.), Neukantianismus..., s. 265. 


\subsubsection{Zarachowanie jako operator powinnościowy}

Jak już wspomniałam, zarachowanie peryferyjne jest definiowane w fazie neokantowskiej jako „powiązanie między stanem faktycznym a następstwem”28. Podobnie, jak w HP, Kelsen wskazuje, że kiedy hipotetyczne sądy odnoszące się do bytu mają strukturę:

Jeśli A, to musi być $\mathrm{B}$

to w świecie powinności przybierają następującą postać:

Jeśli A, to powinno być B

gdzie słowo „powinno" jest wyrazem zarachowania peryferyjnego ${ }^{29}$.

Z przytoczonej definicji wynika, że zdecydowanie pojęcie zarachowania w czystej teorii prawa różni się od powszechnie przyjętego rozumienia ${ }^{30}$. Zarachowanie klasyczne jest ściśle powiązane z odpowiedzialnością, co dla Kelsena, jak wskazuje Ebenstein, jest sformułowaniem niedostatecznie precyzyjnym. Dzieje się tak, ponieważ koncepcja odpowiedzialności łączy zachowanie niezgodne z prawem z daną osobą, natomiast zarachowanie peryferyjne łączy okreŚlone zachowanie z sankcją ${ }^{31}$. Kelsen zauważa, że zarówno w naturze, jak i w rzeczywistości prawnej określony warunek pociąga za sobą określone następstwo, ale inna jest natura tych powiązań. Powinność nie ma charakteru koniecznego, który dla odmiany jest powiązany z przyczynowością ${ }^{32}$. Zarachowanie jako powiązanie analogiczne do powiązania przyczynowo-skutkowego z punktu widzenia gramatyki wyraża się w sformułowaniu „powinien” ${ }^{33}$. Kelsen pisze:

Sąd, „gdy ktoś kradnie powinien być ukarany” w sferze pozytywnego systemu prawnego implikuje nie mniejsze obowiązywanie niż stwierdzenie: gdy ciało zostaje rozgrzane, rozciąga się ${ }^{34}$.

Według Paulsona, zarachowanie przejawia się w szczególności w zrekonstruowanej idealnej lingwistycznej formie normy prawnej, czyli w normie powstałej

${ }^{28}$ ASL, s. 49.

${ }^{29}$ RR1, s. 34-35.

${ }^{30}$ Zob. H. Kelsen, Rechtswissenschaft oder als Norm - oder als Kulturwissenschaft, [w:] H. Klecatsky, R. Marcic, H. Schambeck (Hrsg.), Die Wiener..., s. 235.

${ }^{31}$ W. Ebenstein, The PureTheory of Law: Demythologizing Legal Thought, „California Law Review" 1971, s. 635; S.L. Paulson, Die Zurechnungals apriorische Kategorie in der Rechtslehre Hans Kelsens, [w:] M. Kaufmann, J. Renzikowski (Hrsg.), Zurechnung als Operationaliesierung von Verantwortung, Peter Lang, New York 2004, s. 103.

32 HP II, s. VI-VII.

${ }^{33}$ Ibidem, s. IX.

${ }^{34}$ Ibidem, s. VII. 
najczęściej z kilku przepisów ${ }^{35}$. Dopiero zrekonstruowana norma prawna może zawierać w sobie kategorię zarachowania peryferyjnego, dopiero tam bowiem może dojść do połączenia opisu deliktu i sankcjiib. Paulson zauważa, że samo sformułowanie ,idealna lingwistyczna forma normy prawnej” pojawiło się już w HP. Wtedy już Kelsen zauważył, że jeśli taka forma istnieje, to jest jednocześnie formą dla prawa pozytywnego i pomaga w rozróżnieniu prawa i moralności. W fazie klasycznej Kelsen dochodzi do wniosku, że zarachowanie peryferyjne stanowi podstawę dla takiego sformułowania normy prawnej, ponieważ, będąc łącznikiem pomiędzy warunkiem prawnego i prawnej konsekwencji, wymusza taką strukturę poprzez wykluczenie konstrukcji normy jako imperatywu (czyli normy, w której brak jest warunku prawnego $)^{37}$. W idealnej formie normy prawnej mamy do czynienia $\mathrm{z}$ organem, który posiada jedynie kompetencję zastosowania sankcji. W tym zresztą wyraża się powinność, że pod określonymi warunkami kompetentny organ nałoży sankcję $e^{38}$. Stanowisko to krytykuje Renzikowski, wskazując, że powinność zawarta w normie sankcjonowanej ma charakter kategoryczny dla sędziego. Jest to uzasadnione tym, że nie ma on swobody decyzji odnośnie do ukarania złodzieja ze względu na obowiązek nałożenia kary zawsze, gdy tylko spełnione są warunki zastosowania sankcji ${ }^{39}$. Wydaje się jednak, że z uwagi na pozbawienie powinności koniecznego charakteru, bardziej trafne jest stanowisko Paulsona. Konkludując, norma prawna ukonstytuowana przez naukę prawa jest normą zarachowującą. Jak wskazuje Paulson, jest tym samym lustrzanym odbiciem przymusu, który jest zawarty w hipotetycznie sformułowanej normie sankcjonującej skierowanej do odpowiedniego organu ${ }^{40}$.

W kontekście twierdzenia, że zarachowanie peryferyjne łączy dwa stany faktyczne, można zadać pytanie, czym według Kelsena jest stan faktyczny (Tatbestand). Zdaniem Paulsona, to termin techniczny zawierający w sobie pojęcie warunku prawnego i następstwa prawnego ${ }^{41}$. Kelsen precyzuje, że takie ujęcie można skonkretyzować poprzez zdanie, że „ktoś ze względu” na jego delikt zostanie ukarany, jakaś egzekucja dojdzie do skutku ze względu na niezapłacony $\mathrm{d}_{\mathrm{ug}} \mathrm{g}^{42}$. Według Paulsona jednak to doprecyzowanie tworzy nowy problem. Mianowicie, poprzez słowo „ktoś” $\mathrm{w}$ pojęcie zarachowania peryferyjnego zostanie zaangażowany podmiot, zawierający się już w stanie faktycznym. Kelsen ma tego świadomość i taką tezę zdecydowanie odrzuca, twierdząc, że nie chodzi o człowieka jako takiego, lecz o określone zachowania i zaniechania ${ }^{43}$. Kelsen pisze:

\footnotetext{
${ }^{35}$ Należy zaznaczyć, że Kelsen rzadko używa określenia „przepis prawny” (Vorschrift).

36 Zob. ASL, s. 49.

${ }^{37}$ RR2, s. 106; S.L. Paulson, Die Zurechnung..., s. 113.

38 S.L. Paulson, Die Zurechnung..., s. 113.

39 J. Renzikowski, Der Begriff..., s. 264.

40 S.L. Paulson, On the Kelsen..., s. 209.

${ }^{41}$ S.L. Paulson, Die Zurechnung..., s. 103.

${ }_{42}$ RR1, 1934, s. 34.

${ }^{43}$ S.L. Paulson, Die Zurechnung..., s. 103.
} 
Podmiot prawny jest identyfikowany z człowiekiem. I czy faktycznie człowiek nie jest podmiotem prawa? Czy człowiek nie jest przeciwstawiany prawu, czy prawo i człowiek nie są dwoma różnymi obiektami? Nie ludzie, lecz osoba jest obiektem prawoznawstwa ${ }^{44}$.

Paulson dodaje, że w przypadku zarachowania nie chodzi ani o jakiś sztuczny podmiot prawny, ani o człowieka. Określenie „ktoś” może być po prostu rozpatrywane $\mathrm{w}$ kontekście świata normatywnego ${ }^{45}$. Jednak pytanie: co oznacza pojęcie „stanu faktycznego" w odniesieniu do zarachowania peryferyjnego, pozostaje nadal otwarte. W zakresie pojęcia stanu faktycznego znajdują się dwa elementy: warunek prawny i następstwo prawne. Kelsen zajmuje się głównie pierwszym z nich, wskazując jako jeden z możliwych stanów faktycznych ludzkie zachowania lub zaniechania i zdarzenia. To one podlegają zarachowaniu. Warunek prawny zawierający stan faktyczny nie musi być pojedynczym aktem. Może składać się z wielu stopni (na przykład: kiedy „,a” i kiedy „,b” i kiedy „,c”, to powinno „Z”). Ów łańcuch warunków czyni akty przymusu „ostatnim taktem w systemie dynamiki prawa" ${ }^{46}$. Jako przykład na gruncie prawa karnego podaje Kelsen następującą konstrukcję: (1) kiedy ktoś kradnie i (2) kiedy określony organ państwowy wniesie skargę, (3) sąd powinien ukarać. Z kolei na gruncie prawa cywilnego przykład wyglądałby następująco: (1) kiedy dwóch ludzi coś ustali i (2) kiedy jeden się z tego nie wywiąże i (3) drugi wniesie powództwo, to sąd powinien doprowadzić do wyegzekwowania zobowiązania ${ }^{47}$. W tym miejscu wyraźnie widoczne jest zderzenie pojęcia idealnej lingwistycznej formy normy prawnej z zastosowanym pojęciem pełnej normy prawnej. Pomimo powyższych, Paulson wskazuje, że pojęcie następstwa prawnego pozostaje niewyjaśnione. Wiadomo jedynie, że nie chodzi o człowieka ani o sztuczny podmiot prawa ${ }^{48}$. Według niego, należy szukać takiego sformułowania następstwa prawnego, które byłoby bezpodmiotowe, odnoszące się do działania lub zaniechania, podlegające zarachowaniu oraz nieuwikłane w powiązania przyczynowo-skutkowe. Mogłoby ono brzmieć następująco:

kiedy określone zachowanie typu „h” zostanie dokonane, wówczas nabywa ono cechę bycia podstawą odpowiedzialności ${ }^{49}$.

Paulson zaznacza, iż wyrażenie „zachowanie”, mimo że w potocznym języku jest ściśle powiązane z pierwiastkiem ludzkim, to, w świecie powinności, musi być rozpatrywane jako wzór spełnienia warunku prawnego. Dzięki temu stan faktyczny może zostać zarachowany oraz brak jest konieczności uwzględnie-

\footnotetext{
${ }^{44}$ ASL, s. 62.

45 S.L. Paulson, Die Zurechnung..., s. 104.

46 ASL, s. 51.

47 Ibidem, s. 52.

48 S.L. Paulson, Die Zurechnung..., s. 105.

49 Ibidem.
} 
nia powiązań przyczynowo-skutkowych. Paulson podkreśla, że w rezultacie zarachowanie peryferyjne jako kategoria a priori może być odróżniona od kategorii przyczynowości.

Renzikowski również wskazuje na wątpliwości związane z pojęciem następstwa prawnego, zauważając, że według Kelsena każda norma prawna zawiera w sobie zagrożenie sankcją sprowadzającą się albo do wymierzenia kary, albo do zastosowania przymusu za określone zachowanie. Zatem, następstwem prawnym według Renzikowskiego jest sankcja zarachowana określonemu ludzkiemu zachowaniu $^{50}$. Porównując interpretacje Paulsonowską z Renzikowskiego, wydaje się, że ta druga bliższa jest dosłownemu rozumieniu słów Kelsena, podczas gdy pierwsza zbliża zarachowanie peryferyjne do zarachowania klasycznego poprzez wprowadzenie pojęcia odpowiedzialności. Należałoby zatem postawić pytanie, co konkretnie oznacza odpowiedzialność w Paulsonowskim ujęciu? Owo pojęcie może wiązać się z nałożeniem sankcji, która wydaje się następnym krokiem. Zamiast zatem dwustopniowej struktury warunku i następstwa, wchodziłaby $\mathrm{w}$ grę struktura trójstopniowa: warunek - zarachowanie - następstwo (w postaci odpowiedzialności) - akt przymusu. Jednak wtedy powstaje kolejne pytanie, to jest o łącznik między odpowiedzialnością a aktem przymusu. Czy jest to również zarachowanie, czy może przyczynowość? Wydaje się, że w zdaniu: ,jeśli ktoś jest odpowiedzialny, to nałożony zostanie na niego akt przymusu", widoczne jest powiązanie normatywne, ponieważ nie ma ono charakteru koniecznego i musi wynikać z jakiegoś aktu prawnego.

Jeśli zatem uznać, na gruncie ontologii, tylko dwie zasady wynikające $\mathrm{z}$ bytu i powinności, to wykluczając przyczynowość, należy przyjąć, że jest to zarachowanie. Wtedy pojawia się jednak pytanie, który to rodzaj zarachowania? Peryferyjne, centralne czy może jakaś jego nowa odmiana? Trzecia możliwość raczej nie wchodzi w grę, ponieważ stanowiłaby zbyt poważną ingerencję w teorię Kelsena, stanowiąc jej nadinterpretację. Czy zatem jest to zarachowanie peryferyjne? Z jednej strony, tak wynikałoby z jego definicji; z drugiej, w myśl przedstawionej interpretacji zarachowanie peryferyjne pojawiło się już na wcześniejszym etapie. Zatem, czy jest to zarachowanie centralne? Zarachowanie centralne łączy określony stan faktyczny z podmiotem. Odpowiedzialność trzeba wówczas traktować w kategoriach faktu (czyli, gdy stanie się faktem w świecie bytu), natomiast nałożenie sankcji należy postrzegać z podmiotowego punktu widzenia, jako obowiązek określonego podmiotu (organu państwowego). Wydaje się jednak, że przedstawiona interpretacja ma wyjątkowo karkołomny charakter, choć jej niewątpliwą zaletą byłoby wyjaśnienie relacji zarachowania peryferyjnego do centralnego. Jeśli jednak bierze się ją pod uwagę, to właściwszym ujęciem w duchu kelsenowskim byłoby takie, w którym najpierw mamy do czynienia z zarachowaniem centralnym (łączyłoby wtedy stan faktyczny z odpowiedzialnością), a dopiero później z zarachowaniem

${ }^{50}$ J. Renzikowski, Der Begriff..., s. 256. 
peryferyjnym. Jako alternatywną można zaproponować jeszcze inną interpretację paulsonowskiej propozycji, w myśl której pojęcie odpowiedzialności ujęte jest szeroko i obejmuje swoim zakresem obowiązek zastosowania sankcji. Jednak wówczas rodzi się pytanie, po co zastępować pojęcie aktu przymusu pojęciem odpowiedzialności. Wydaje się zatem, że w tym przypadku sprawdza się zasada, że rozwiązania proste są najtrafniejsze i należy opowiedzieć się za propozycją Renzikowskiego. Zanim jednak udzieli się ostatecznej odpowiedzi, warto sprawdzić, czy Kelsen nie wyjaśniał tej kwestii. Być może wskazówką będzie niniejszy fragment:

Stany faktyczne powiązane ze sobą w normie co do zasady przedstawiają ludzkie zachowania. Jednak ludzkie zachowanie nie jest samo w sobie zawartością normy; występuje ono również w powiązaniu z procesami, które ludzkimi zachowaniami nie są i powszechnie znane są jako zdarzenia. Koniecznie akt przymusu [...] musi zostać ukazany jako ludzkie zachowanie: ponieważ to jest zastosowanie przymusu przez określonych ludzi przeciw innym ludziom. Stan faktyczny będący warunkiem może być zwykłym zdarzeniem ${ }^{51}$.

\section{Dalej Kelsen rozwiewa wszelkie wątpliwości:}

Sąd wyrażający zarachowanie to wypowiedź o powiązaniu między stanem faktycznym będącym przedmiotem warunku, który zostanie zarachowany i zawarunkowanym następstwem, aktem przymusu. Zatem to, że jakiś stan fatyczny zostaje zarachowany, zostaje wyłącznie określone przez to, że ów stan faktyczny został ustanowiony warunkiem aktu przymusu ${ }^{52}$.

Tym, co rzuca się w oczy w przytoczonych cytatach, jest akt przymusu. Wydawać by się mogło, że Kelsen pisząc o zarachowaniu peryferyjnym, ma na myśli raczej normy generalne ${ }^{53}$. Jednak powyższe cytaty oraz ujęcie zarachowania jako „ostatniego taktu dynamiczności prawa” wskazywałoby raczej na to, że zarachowanie peryferyjne odnosi się tylko do norm indywidualnych. Rozwiązaniem tego problemu mogłoby być przyjęcie, że w ujęciu statycznym horyzontalnym Kelsen rozpatruje zarachowanie peryferyjne w odniesieniu do norm generalnych, w których następstwem jest sankcja ustanawiająca akt przymusu. Natomiast w ujęciu wertykalnym, odnoszącym się do hierarchicznej struktury prawa, zarachowanie peryferyjne dotyczy norm indywidualnych. Należy jednak przyznać, że nie wszyscy uważają takie rozwiązanie za satysfakcjonujące. Heidemann opisuje zaistniałą sytuacje w następujący sposób:

Praktycznie w tym samym czasie wraz z wprowadzeniem kategorii zarachowania peryferyjnego [Kelsen - przyp. M.Z.] przejął od Adolfa Merkla teorię dynamicznej struktury prawa. W ten sposób jego koncepcja zarachowania peryferyjnego przystosowana do płaszczyzny norm generalnych nie została na pozostałych płaszczyznach uzasadniona. Ani indywidualnych norm [...], ani upoważniających norm generalnych nie da się zrekonstruować w sposób adekwatny jako sądów zarachowania ${ }^{54}$.

\footnotetext{
${ }^{51}$ ASL, s. 48-49.

52 Ibidem, s. 50.

53 Zob. C. Heidemann, Der Begriff der..., s. 20.

${ }^{54}$ Ibidem.
} 
Heidemann, odnosząc się już do RR2, wskazuje na kolejny problem: relacji zarachowania i normy. Problem ten zostanie jednak omówiony w tym rozdziale, ponieważ dzięki temu uwidacznia się powód, dla którego w fazie neokantowskiej możliwe było tylko jedno rozwiązanie.

Zarachowanie peryferyjne można rozpatrywać na trzy sposoby: (1) połączenie dwóch stanów opisanych w normie, (2) połączenie dwóch stanów poprzez normę, (3) przyporządkowanie dwóch faktycznie danych stanów ze względu na zastosowanie normy ${ }^{55}$. Nie do końca jest jasne, który z tych sposobów miał na myśli Kelsen. Być może odpowiedź na to pytanie znajduje się w następującym fragmencie z RR1:

poprzez połączenie jakiegoś szkodliwego społecznie zachowania ludzkiego, z jakimś uważanym przez niego [sprawcy - przyp. M.Z.] za zło aktem przymusu ${ }^{56}$.

Nie ulega wątpliwości, że owo „połączenie” to właśnie zarachowanie. Przytoczone zdanie zdaje się wskazywać na trzecią opcję. Mamy zatem dwa stany w normie, połączone poprzez normę. Czy jest to jednak rozwiązanie satysfakcjonujące? Wydaje się, że o ile pierwszy przypadek wskazywałby na normę składającą się z trzech elementów: opisu dwóch stanów faktycznych oraz zarachowania, to druga możliwość wskazuje na bardziej dynamiczny aspekt. Istnieją dwa stany, które zostają poprzez normę (będącą zasadą zarachowania) połączone. Tym połączeniem jest zarachowanie. Wątpliwości może tu nasuwać status tych dwóch stanów. Nie są one bowiem elementami normy, skoro dopiero zostają przez normę połączone. Skoro tak, to muszą należeć do sfery faktów. Nie mogą być jednak konkretnymi stanami faktycznymi, ponieważ taką sytuację przewiduje trzecia możliwość. W grę wchodzi zatem ogólny opis pewnej klasy stanów faktycznych, który nabiera cech normatywnych dzięki zarachowaniu dokonanemu poprzez normę. Jednak takie ujęcie rodzi nowy problem, ponieważ wynikałoby z niego, że norma generalna wytwarza samą siebie. To rozwiązanie nabierze sensu dopiero w trzeciej fazie, gdy Kelsen dokona podziału na normy prawne i zdania prawne. Wówczas zdanie prawne jako opisujące normę będzie zawierać w sobie zarachowanie, łączące dwa stany mające charakter opisu. W fazie neokantowskiej można byłoby spróbować bronić tej koncepcji, przyjmując, że takie rozwiązanie oznaczałoby, że zarachowanie nie znajduje się w samej normie, tylko poza nią. Skoro zatem językowym wyrazem zarachowania jest znajdujące się w normie słowo „powinien”, to można by przyjąć, że norma jest jakimś swoistym performatywem (swoistym, bo odnoszącym się do sfery powinności a nie bytu), w rezultacie którego wytworzone zostałoby

${ }^{55}$ C. Heidemann, Die Norm als..., s. 119; wprawdzie te trzy możliwości Heidemann odnosi do trzeciej fazy, ale wydaje się, że rozważenie ich również w tym miejscu jest uzasadnione i może pomóc w wyjaśnieniu pojęcia zarachowania.

${ }^{56}$ RR1, s. 43. 
zarachowanie ${ }^{57}$. Jest to ciekawa koncepcja, nawiązująca do językowego wymiaru norm prawnych, jednak za wcześnie na nią - taki kontekst będzie w pełni uzasadniony dopiero w ATN. Pozostaje trzecie rozwiązanie, które wyraźnie odwołuje się do norm indywidualnych. Tu również mamy do czynienia $\mathrm{z}$ dwustopniowością: norma prawna jako zasada zarachowania powoduje połączenie dwóch konkretnych stanów faktycznych w zdaniu prawnym. Widać zatem wyraźnie, że w fazie neokantowskiej jedynie pierwsza możliwość nie budzi większych kontrowersji. Przy okazji uwidacznia się, dlaczego Heidemann zajął się tym problemem dopiero podczas opisu zarachowania w fazie realistycznej.

Podsumowując tę część rozważań, można przyjąć, że zarachowanie peryferyjne jest w Kelsenowskiej konstrukcji elementem koniecznym, konsekwencją założeń metodologicznych, przede wszystkim dualizmu bytu i powinności. Schemat rozumowania Kelsena uzasadniającego wprowadzenie pojęcia zarachowania można zrekonstruować następująco: (1) nie da się poznać prawa jako prawa, jeśli nie wyeliminuje się wszelkich elementów wobec prawa obcych; (2) świat przyrody to świat bytu, rzeczywistości opartej na powiązaniach przyczynowych; (3) prawo należy do sfery powinności; (4) należy zatem wyeliminować wszelkie momenty w prawie nawiązujące do powiązań przyczynowych; (5) w miejsce samej przyczynowości wchodzi zarachowanie. Warto już tutaj nadmienić, że w kontekście argumentu transcendentalnego dochodzi kolejna przesłanka: (6) tak jak przyczynowość jest aprioryczną kategorią umożliwiającą poznanie w świecie przyrody, tak zarachowanie pełni tę funkcję w świecie norm. Według Kelsena, wszystkie przesłanki powinny być spełnione łącznie (poza ostatnią, która jest specyficzna dla fazy klasycznej). W związku z tym można postawić pytania, czy w istocie poznanie prawa jest wykluczone, jeśli będziemy rozpatrywać to zagadnienie z uwzględnieniem elementów obcych; czy w istocie przeciwstawienie bytu i powinności jest uzasadnione. A jeśli na dwa wcześniejsze pytanie udzieli się odpowiedzi pozytywnej, to czy w świecie powinności nie ma miejsca na powiązania przyczynowo-skutkowe. Jak już wcześniej zostało wykazane, dualizm bytu i powinności nie jest aż tak radykalnym przeciwstawieniem, jak to ujmuje Kelsen. Daje się obronić tylko na płaszczyźnie logicznej, która być może stanowi dobry punkt wyjścia dla normatywizmu, ale jako uzasadnienie dla prawa nie wystarcza. Z kolei nie ulega wątpliwości, że konstrukcja zarachowania w prawie jest istotnym elementem. Najlepszym dowodem na to jest brak (w niektórych sytuacjach) związku przyczynowego jako przesłanki odpowiedzialności. Jednak w tym wypadku chodzi o zarachowanie klasyczne. Czy zarachowanie peryferyjne jest równie koniecznym elementem? Jeśli chce się jakoś nazwać to „coś”, co łączy warunek z następstwem

${ }^{57} \mathrm{Na}$ interesującą analogię między normą a performatywem wskazują Opałek i Wróblewski. Według nich, kwestia istnienia skuteczego performatywu jest analogiczna do Kelsenowskiej koncepcji obowiązywania norm (K. Opałek, J. Wróblewski, Prawo: metodologia, filozofia, teoria prawa, PWN, Warszawa 1991, s. 180; K. Opałek, Studia z teorii i filozofii prawa, Monografie Wydziału Prawa i Administracji Uniwersytetu Jagiellońskiego/A - Monografie, Kraków 1997, s. 56). 
- warunek zastosowania sankcji z samą sankcją, to na pewno nie będziemy mieli do czynienia z przyczynowością, ponieważ ów łącznik ma charakter normatywny. $Z$ drugiej strony, jego charakter jest analogiczny do charakteru przyczynowości. Wydaje się zatem, że wprowadzenie konstrukcji zarachowania peryferyjnego jako elementu konstrukcyjnego normy prawnej jest uzasadnione. Dyskusyjne natomiast mogą być funkcje, które zarachowanie peryferyjne pełni, w szczególności rola zarachowania jako relatywnej kategorii a priori.

\subsubsection{Zarachowanie $i$ argument transcendentalny}

Jednym z najbardziej charakterystycznych elementów fazy neokantowskiej jest argument transcendentalny. Za punkt wyjścia dla jego wyjaśnienia można obrać Cohenowską metodę transcendentalną, polegającą na analizie przesłanek możliwego poznania ${ }^{58}$, co ma na celu udzielenie odpowiedzi na pytanie transcendentalne, jak możliwe jest poznanie. Nie jest zadaniem niniejszego opracowania opis filozofii Hermanna Cohena, jednak warto poświęcić kilka zdań tym założeniom, które później stały się inspiracją dla Kelsena.

Jak wskazuje Dore, Cohen krytykował Kanta za oparcie uzasadnienia możliwości nauki w odwołaniu do władz poznawczych podmiotu i kategorii poznania, ponieważ ma to prowadzić do relatywizmu. Jest zatem wręcz tak, że dualizm: fenomen - noumen stoi w sprzeczności z próbami uprawomocnienia nauki. W zamian za to Cohen proponuje inne podejście: nauka sama w sobie jest już danym nam faktem, a warunki możliwego poznania tkwią w niej samej ${ }^{59}$. Tak jak Cohen uważa fakt nauki za dany, tak dla Kelsena faktami już danymi - w zależności od odmiany pytania transcendentalnego - były nauka prawa i prawo pozytywne ${ }^{60}$. Kelsen przyjmuje zatem własną wersję pytania transcendentalnego: ,jak możliwe jest prawo jako obiekt poznania"61. Inną odmianę tego pytania uzyskuje Kelsen, odwołując się do obowiązywania: pyta mianowicie, ,jak możliwe jest, że prawo obowiązuje?"'22 I znowu tak, jak warunki możliwego poznania tkwią w samej nauce, u Kelsena, roszczenie prawa pozytywnego do obowiązywania zawiera się w samym prawie pozytywnym ${ }^{63}$. Hammer zwraca uwagę, że rola pytania transcendentalnego $\mathrm{w}$ kelsenowskim normatywizmie jest doniosła, ponieważ jest z nim powiązane założenie czystości teorii prawa ${ }^{64}$.

58 C. Heidemann, Geltung und..., s. 205.

${ }^{59}$ I.I. Dore, The Epistemological..., s. 569.

${ }^{60}$ Ibidem, s. 571, 575.

${ }^{61}$ M. Zirk-Sadowski, Wprowadzenie do filozofii prawa, Zakamycze, Kraków 2000, s. 49.

62 RR2, s. 196.

${ }^{63}$ I.I. Dore, The Epistemological..., s. 571-572.

${ }^{64}$ S. Hammer, A Neo-Kantian Theory of Legal Knowledge in Kelsen's Pure Theory of Law?, [w:] S.L. Paulson, B. Litschewski-Paulson (eds), Normativity and Norms, Critical Perspective on Kelsenian Themes, Clarendon Press, Oxford 1998, s. 181-182. 
Kelsen zatem pyta, jak prawo może być postrzegane normatywnie, czyli z punktu widzenia powinności, odrębne od faktów empirycznych należących do sfery bytu, do tego bez uwikłania się w metafizykę, czy też doktryny prawa natury. Zirk-Sadowski wskazuje, że kluczem do udzielenia odpowiedzi jest normatywny charakter nauki prawa, ponieważ jeśli przyjmie się neokantowską tezę, że metoda poznania konstytuuje swój przedmiot, to normatywność nie tkwi $\mathrm{w}$ alogicznym materiale tekstu prawnego, lecz w nauce prawa ${ }^{65}$. Teza o konstytutywnej roli metody w poznaniu jest, jak wskazuje Paulson, stwierdzeniem, że nauka prawa koncentruje się na określonym, alogicznym materiale prawnym, którym są akty woli. Są one następnie porządkowane przez kategorie, przybierając tym samym postać hipotetycznie sformułowanych norm prawnych ${ }^{66}$.

Odpowiedzią na pytanie transcendentalne jest właśnie argument transcendentalny. Jego specyfika w wersji, która interesuje Kelsena, wynika z tego, że z jednej strony ma za zadanie udzielenie odpowiedzi na pytanie: ,jak możliwe jest poznanie prawne?”, a nie „czy jest możliwe?”, z drugiej, jego celem jest wykazanie potrzeby założenia innych elementów teorii, poddawanych w wątpliwośćc ${ }^{67}$. W przypadku Kelsena chodziło przede wszystkim o konieczność przyjęcia konstrukcji normy podstawowej, zarachowania peryferyjnego i powinności. Na początku warto przybliżyć problematykę transcendentalnego uzasadnienia nauki prawa. W pierwszej kolejności zostanie przedstawiona struktura argumentu transcendentalnego u Kanta i w teorii prawa Kelsena, by następnie przejść do analizy powinności, normy podstawowej i zarachowania jako relatywnych kategorii a priori.

Argument transcendentalny w czystej teorii prawa został zrekonstruowany przez Paulsona. Jego geneza jest ścisłe związania z sceptycyzmem filozoficznym, będącym nurtem zaprzeczającym lub poddającym w wątpliwości określony aspekt rzeczywistości. Argument transcendentalny ma za zadanie odeprzeć zarzuty sceptyków, już na mocy samej struktury. Polega ona na tym, że jeśli rozumowanie dotyczące określonej formy wiedzy nie jest możliwe bez użycia pewnych elementów tej formy, to sceptycy nie są w stanie zakwestionować tej formy wiedzy bez jej zastosowania ${ }^{68}$. Paulson podkreśla, że Kelsen nie ujął opisu argumentu transcendentalnego, jednak analiza jego dzieł nie pozostawia wątpliwości - że świadomie lub nie - odwoływał się do niego ${ }^{69}$.

${ }^{65}$ M. Zirk-Sadowski, Wprowadzenie..., s. 49.

${ }^{66}$ S.L. Paulson, The Neokantian Dimension of Kelsen's Pure Theory of Law, Oxford Legal Studies, Oxford University Press, Oxford 1992, s. 323-324; C. Heidemann, Die Norm als..., s. 48-49.

${ }^{67}$ U Kanta chodzi o wersję argumentu transcendentalnego odnoszącego się do przyrodoznawstwa, w której wiadomo, że istnieje możliwość autentycznego poznania przyrody, które jest możliwe przy założeniu m.in. przyczynowości. Przyczynowość, jak to udowodnił Hume, nie wynika z doświadczenia, zatem przyczynowość jest kategorią a priori.

${ }^{68}$ S.L. Paulson, The Neokantian..., s. 325.

${ }^{69}$ S.L. Paulson, Kelsen in ..., s. 484. 
Argument transcendentalny można przedstawić w postaci schematu:

przesłanka: myślę, że $\mathrm{X}$ albo posiadam koncepcję $\mathrm{Y}$

przesłanka transcendentalna: X (albo Y) są możliwe, jeśli Z

wniosek: Z

gdzie $\mathrm{Z}$ jest elementem poddanym w wątpliwość przez sceptyków ${ }^{70}$.

U Kanta, argument transcendentalny nawiązuje do przewrotu kopernikańskiego, polegającego na stwierdzeniu, że poznanie zdeterminowane jest poprzez warunki poznania, transcendentalne kategorie niezależne od przedmiotu poznania $^{71}$. Jego struktura wygląda następująco:

\section{$P$}

P jest możliwe tylko, gdy Q

wniosek: Q

Kant przyjmuje, że istnieje zdanie „P”, mające wartość prawdy, jednak pod warunkiem, że prawdziwe jest zdanie „Q”. Zdanie „P” dotyczy wrażeń dostarczanych świadomości, zaś zdanie „Q” dotyczy kantowskiej kategorii (najczęściej przyczynowości). Jeśli zostanie udowodniona prawdziwość zdania „Q”, to możliwe jest dowodzenie prawdziwości kolejnych zdań, oznaczonych jako „R” (na przykład u Kanta było to wykazanie, że prawa natury są sądami syntetycznymi a priori). Zatem, czwartym krokiem będzie:

Więc R.

$\mathrm{Na}$ gruncie nauki prawa rodzi się problem, jak bardzo argument transcendentalny musi się różnić od tego przedstawionego przez Kanta dotyczącego nauk przyrodniczych i sfery bytu. Według Paulsona, aby zrozumieć jego kelsenowską wersję, należy rozróżnić jego progresywną i regresywną odmianę. Wersja progresywna została przedstawiona powyżej, natomiast regresywna charakterystyczna dla neokantystów, w szczególności Cohena ${ }^{72}$, rozpoczyna się od mocnej przesłanki R i wygląda następująco:

przesłanka 1: R (zdanie dotyczące poznania - dane u neokantystów, u Kanta tak jakby było dane ${ }^{73}$ ), przesłanka 2: R zachodzi wtedy, gdy Q (kategoria jako warunek),

wniosek: Q (kategoria jako konkluzja).

${ }^{70}$ S.L. Paulson, On Transcendental Arguments. Their Recasting in Terms of Belief and the Ensuing Transformation of Kelsen's Pure Theory of Law, „Notre Dame Law Review” 2000, vol. 75, s. 1775-1779.

71 S.L. Paulson, Toward a Periodisation of the Pure Theory of Law, [w:] L. Gianformaggio (ed.), Hans Kelsen's Legal Theory a Diachotonic Point of View, G. Giappichelli Editore 1990, s. 38; idem, The Neokantian..., s. 326-332; idem, On the Kelsen..., s. 209; idem, Lässt sich die Reine Rechtslehre transzendental begründen?, „Rechtstheorie“ 1990, Bd. 21, s. 172.

${ }^{72}$ C. Heidemann, Geltung und..., s. 205.

${ }^{73}$ S.L. Paulson, On the Kelsen..., s. 212. 
Wersja regresywna, inaczej zwana przez Kanta analityczną, polega na tym, że punktem wyjścia jest coś, co już się wie i traktuje jako dane. Następnie ustala się przesłanki, na mocy których ta wiedza jest możliwa. W dziedzinie nauki prawa kategorią wymagającą udowodnienia może być albo powinność w funkcji zarachowania, samo zarachowanie, albo norma podstawowa. Argument transcendentalny w wersji kelsenowskiej, według Paulsona, zatem, zawiera następujące stwierdzenia ${ }^{74}$ :

przesłanka 1: poznanie prawne jest możliwe (dane),

przesłanka 2: poznanie prawne jest możliwe jedynie, jeśli założy się relatywną kategorię a priori, którą może być zarachowanie, norma podstawowa albo powinność (przesłanka transcendentalna),

wniosek: należy założyć relatywną kategorię a priori (wniosek transcendentalny).

Zatem, odpowiedź na pytanie o to, jak możliwa jest nauka prawa (a już nie moralności), według Dore’a jest następująca: nauka prawa jest możliwa dzięki relatywnej kategorii a priori ${ }^{75}$. Jest to zarazem differentia specifica, coś, co pozwala na odróżnienie prawa od innych zjawisk o charakterze normatywnym.

Wracając do struktury argumentu transcendentalnego, nietrudno zauważyć, że Kelsen faktycznie użył regresywnej wersji argumentu transcendentalnego i mocnej przesłanki „R”. Jaki był tego powód? Kantowi potrzebna była wersja progresywna, albowiem jednym z jego celów była polemika ze sceptykami ${ }^{76}$, którzy byli zmuszeni do uznania przesłanki słabej (odnoszącej się do materiału wrażeniowego oddziałującego na zmysły) oraz wszelkich jej konsekwencji, ponieważ owe dane mogą być interpretowane na różne sposoby. Przesłanki „R” sceptycy nie uznaliby jako danej. Kelsen, nie mając tego problemu, mógł posłużyć się regresywną wersją i silniejszą przesłanką. Gdyby natomiast zastosował wersję progresywną, to sceptycy mogliby przyjąć pierwszą przesłankę bez konieczności przyjęcia pozostałych (uznając tylko, że istnieje pewien materiał prawny). W regresywnej wersji argumentu pojawiają się jednak wątpliwości, czy normatywne poznanie musi koniecznie zakładać relatywną kategorię a priori. Jak wskazuje Paulson, rozwiązaniem mogłoby być tutaj wsparcie się na progresywnej wersji argumentu, w której konieczność istnienia relatywnej kategorii a priori byłaby możliwa do wyprowadzenia, ale akurat ta wersja w naukach prawnych nie ma zastosowania ze względu na istnienie alternatywnych wyjaśnień spójności materiału prawnego, na przykład historii czy socjologii, czego Kelsen był świadom. Według Paulsona, problem sprowadza się zatem do pytania, czy regresywna wersja transcendentalnego argumentu w ogóle może funkcjonować samodzielnie. Druga przesłanka byłaby fałszywa, jeśli tylko dałoby się wykazać, że istnieje poznanie prawne bez pomocy relatywnej kategorii

\footnotetext{
${ }^{74}$ S.L. Paulson, Toward a ..., s. 326-332; idem, On the Kelsen ..., s. 209; idem, Lässt sich ..., s. 172.

75 I.I. Dore, The Epistemological..., s. 601.

76 Przede wszystkim Humem.
} 
a priori. Kelsen uważał drugą przesłankę za oczywistą, ponieważ jak mu się wydawało, wyeliminował wszystkie inne podstawy poznania norm prawnych szczególnie w odniesieniu do pozytywizmu i doktryn prawa natury. Z drugiej strony jednak, nie podał żadnego przekonującego argumentu przemawiającego za uznaniem pozytywizmu prawniczego, koncepcji prawno-naturalnych oraz normatywizmu jako wyczerpujących i niepozostawiających pola dla innych koncepcji prawa ${ }^{77}$. Paulson konkluduje, że w tej sytuacji, żadnej z wersji transcendentalnego argumentu nie można uznać za satysfakcjonująca, zaś regresywna wersja może być przydatna wyłącznie jako pewien ogólny schemat analizy ${ }^{78}$. Na koniec, próbując obronić argument transcendentalny w wersji kelsenowskiej, analizuje go również w słabszej wersji, gdzie druga przesłanka brzmiałaby następująco: „poznanie norm prawnych jest możliwe, jeśli wierzy się, że kategoria powinności jest w mocy”. Wówczas wniosek przyjąłby postać: „,wierzy się, że kategoria powinności jest w mocy". Jednak, takie ujęcie powoduje radykalną zmianę w charakterze teorii Kelsena: rezygnację z tezy normatywnej na rzecz tezy redukcyjnej ${ }^{79}$.

Argument transcendentalny wiele mówi o strategii, którą przyjął Kelsen, by wybronić swoją teorię. Jest on mu potrzebny, aby uzasadnić rację bytu strategicznych elementów: powinności, zarachowania i normy podstawowej. Gruntowna analiza dokonana przez Paulsona, wykazuje jednak niezbicie, że ta strategia nie spełniła pokładanych w niej nadziei. Zamiast wzmocnić argumentację, dobitnie odsłoniła jej braki, ukazując, w którym dokładnie miejscu teoria Kelsena nie zdaje egzaminu. Jak jednak trafnie wskazuje Dore, fakt ułomności argumentu transcendentalnego nie dyskredytuje całej czystej teorii prawa. Znosi jedynie jej roszczenie do bycia jedyną możliwą ${ }^{80}$.

Z punktu widzenia zarachowania warto jednak przyjrzeć się dyskusji, toczącej się $\mathrm{w}$ ostatnich latach $\mathrm{w}$ doktrynie: która $\mathrm{z}$ trzech wymienionych konstrukcji najlepiej się nadaje na relatywną kategorię a priori. Analiza ta pomoże ukazać kolejne braki czystej teorii prawa w neokantowskim ujęciu. Zanim to jednak nastąpi, warto zacząć od zdefiniowania pojęcia relatywnej kategorii a priori. Próbę wyjaśnienia, co oznacza określenie ,aprioryczny”, podejmuje Robert Alexy. Pierwsza uwaga, która się nasuwa, to dość oczywiste stwierdzenie, że Kelsenowi chodzi o formalne a priori z Krytyki czystego rozumu i odpowiedź na przytaczane już wcześniej pytanie o warunki możliwego poznania prawa. Chodzi zatem o dodanie do listy kantowskich kategorii a priori jeszcze jednej, rozszerzając tym samym

${ }_{77}$ S.L. Paulson, Zwei radikale Objektivirungsprogramme in der Rechtslehre Hans Kelsens, [w:] S.L. Paulson, M. Stolleis (Hrsg.), Hans Kelsen Staatslehrer und Rechtstheoretiker des 20. Jahrhunderts, Mohr Siebeck, Tübingen 2005, s. 200.

${ }^{78}$ S. L. Paulson, The Neokantian..., s. 331; idem, On the Kelsen..., s. 211.

79 S.L. Paulson, On Transcendental..., s. 1793-1795.

${ }^{80}$ I.I. Dore, The Epistemological..., s. 598. 
transcendentalne założenia na świat norm (Geistwissenschaften) ${ }^{81}$. Jak wskazuje Alexy relatywna kategoria a priori nie jest kategorią, która tylko pośredniczy w poznaniu określonego przedmiotu. Wchodzi ona w grę dopiero, gdy inne kategorie, w tym przyczynowość, ukonstytuują poznanie. Innymi słowy, najpierw dostarczany jest empiryczny materiał prawny, który następnie poprzez relatywną kategorię a prori staje się prawem. W związku z tym Alexy nazywa ją ,kategorią drugiego stopnia" ${ }^{82}$. Zatem relatywną kategorię a priori stosuje się podczas interpretacji tego, co zostało już ujęte przez kategorie pierwszego stopnia, aby ukonstytuowała przedmiot poznania, jakim jest norma ${ }^{83}$. Przy takim ujęciu problemu można zadać pytanie, czy mówienie o przyczynowości nie narusza tezy normatywnej, doprowadzając do przełamania dualizmu bytu i powinności. Moim zdaniem, nie ma takiego zagrożenia. Przyczynowość jest konieczna w poznaniu w sferze faktów. Dopiero drugi krok nadaje poznaniu prawa charakter normatywny.

Dlaczego jednak w kontekście filozofii prawa mowa jest o relatywnej kategorii a priori? Relatywizacja, jak wskazuje Paulson, może dotyczyć dwóch aspektów: po pierwsze, poprzez normę podstawową, gdy za pomocą relatywnej apriorycznej kategorii szuka się dla normy funkcji systematyzującej. Systematyzacja nie do końca jednak pokrywa się z tym, co znajduje się w Krytyce czystego rozumu u Kanta. Kelsenowi chodziło raczej o wyodrębnienie porządku prawnego w aspekcie czasowo-przestrzennym, co może zostać spełnione właśnie za pomocą normy podstawowej. Konsekwencją powyższego jest według Paulsona to, że każdy porządek prawny posiada normę podstawową oraz to, że gdy nowy porządek prawny powstanie, szczególnie w miejsce starego (na przykład poprzez rewolucję), to na mocy nowej normy podstawowej. W konkretnym porządku prawnym kategoria zarachowania może być zastosowana tylko wówczas, gdy czasowy i przestrzenny zakres zastosowania norm prawnych zostanie sprecyzowany. Po drugie, kelsenowska kategoria nie do końca odzwierciedla transcendentalne założenia, przez co nie może być uniwersalna. Jest relatywna, w sensie: zrelatywizowana do sfery prawa i tylko w tym zakresie umożliwia poznanie ${ }^{84}$. Sam Kelsen wskazuje, że relatywność jest związana z charakterem samego prawa. Przykładowo anarchizm czy solipsyzm znoszą jego roszczenia do absolutyzmu ${ }^{85}$.

Relatywny charakter apriorycznej kategorii prowokuje Alexego do postawienia pytania, czy w tej sytuacji w ogóle można mówić o a priori. Alexy zauważa przy tym, że to może kwestia definicji mocniejszej odmiany pojęcia a priori (u Kanta) i słabszej (u Kelsena) i wyróżnia trzy cechy kelsenowskiego a priori: (1) pojęcie aprioryczności pomimo jego relatywizacji pozostaje powiązane z po-

${ }^{81}$ R. Alexy, Hans Kelsens Begriff des relativen Apriori, [w:] R. Alexy, L.H. Meyer, S.L. Paulson, G. Sprenger (Hrsg.), Neukantianismus..., s. 193.

82 Ibidem, s. 194.

83 Ibidem, s. 195.

${ }^{84}$ S.L. Paulson, Die Zurechnung..., s. 109-112.

${ }^{85}$ H. Kelsen, Die philosophischen Grundlagen..., s. 276. 
znaniem i tym samym z prawdziwością; (2) Kelsen rozróżnia za Kantem pomiędzy a priori i a posteriori, tworząc $\mathrm{w}$ ten sposób na płaszczyźnie poznania podział na aprioryczność wewnętrzną i zewnętrzną. Kategoria wewnętrzna jest niezbędna (jeśli chce się poznać prawo, to jedynie poprzez kategorię Sollen), natomiast zewnętrzna jest relatywna. Kelsen jednak, jak wskazuje Alexy, ma trudność z udowodnieniem konieczności wewnętrznego a priori; (3) trzecia cecha sprowadza się do pytania, jak bardzo relatywne jest zewnętrzne a priori. Alexy zauważa tu, że Kelsen w kontekście normatywnej teorii prawa nie mówi o jej możliwości, ale konieczności. Może ona dotyczyć trzech aspektów. Pierwszy z nich wiąże się $\mathrm{z}$ celowością $\mathrm{w}$ tym sensie, że istnieje mało celów, których osiągnięcie nie wymagałoby dla swojej skuteczności prawa. W drugim znaczeniu, chodzi o tożsamość kulturową, która bez prawa zostałaby poważnie naruszona. Trzecie znaczenie dotyczy praktycznej konieczności, prowadzącej do powstania praktycznego a priori. Zbliżałoby to jednak prawo do moralności, a zatem z kelsenowskiego punktu widzenia należy ją odrzucić. Alexy podsumowuje, że pozostałe znaczenia konieczności należą do podstawowych założeń teorii Kelsena ${ }^{86}$.

Jak już wspomniano, w doktrynie rozróżnia się trzy postaci argumentu transcendentalnego, gdzie zarachowanie może zostać zastąpione albo konstrukcją normy podstawowej (w ten sposób normę podstawową definiował sam Kelsen), albo powinnością. Warto zadać pytanie, jaka jest różnica między wersjami oraz ewentualnie, która z nich jest najbardziej poprawna. W tym kontekście Alexy zadaje pytanie: czym powinna być kategoria, aby mogła prawu nadać cechę normatywności? Innymi słowy, szuka differentia specifica prawa. Alexy wskazuje, że w każdym $\mathrm{z}$ wymienionych trzech przypadków chodzi tak naprawdę albo o normę rozumianą jako nośnik sensu (Sinngehalt) a przez to należącą do świata myśli (ducha), czyli niepodlegającą zasadom czasoprzestrzeni87 ${ }^{87}$, albo o obowiązywanie ${ }^{88}$. W przypadku normy takie określenie nie wyjaśnia jednak wiele, poza eliminacją naturalistycznego ujęcia. Alexy zatem zadaje pytanie, czym różni się sens zdań oznajmujących od normy i wskazuje, że Kelsen mógł na nie odpowiedzieć odwołując się jedynie do dualizmu bytu i powinności, gdzie powinność jest różnicą gatunkową. Wtedy jednak do prawa trzeba byłoby zaliczyć również normy moralne. Należy więc znaleźć cechę, która odróżniłaby prawo od moralności i jest nią przymus. Zatem - zauważa Alexy - Kelsen nie tylko odróżnia prawo od moralności na materialnej płaszczyźnie (polegającej na tym, że wszystkie pojęcia takie jak sprawiedliwość zostają od prawa odseparowane), ale również strukturalnie, poprzez jego autonomię (Eigengesetzlichkeit) zapewnioną dzięki zastosowaniu poszukiwanej kategorii. Alexy stwierdza, że wygląda to tak, jakby

${ }^{86}$ Ibidem.

${ }^{87}$ R. Alexy zauważa, że mamy tu do czynienia z trzystopniowym schematem: fizyczność, psychiczność i świat myśli (ducha). Rodzi to pytanie o charakterze metafizycznym, czy obok świata fizycznego, psychicznego istnieje ten trzeci świat idei.

${ }_{88}$ R. Alexy, Hans Kelsens..., s. 181-202. 
Kelsen najpierw chciał moralność (jako powinność) zaliczyć do wspólnych pojęć głównych, aby następnie za pomocą „różnicy gatunkowej” od tych pojęć ją odciąć. To powoduje, że pozostaje jednak krótka styczność. W tej sytuacji odpowiedź na zadane na początku pytanie zależy od tego, co Kelsen rozumie pod pojęciem powinności. Zostanie ona zatem omówiona w pierwszej kolejności, by później przejść do omawiania normy podstawowej a na końcu do zarachowania ${ }^{89}$.

\subsubsection{Powinność jako relatywna kategoria a priori}

Za przyjęciem powinności jako relatywnej kategorii a priori przemawia przede wszystkim to, że tak ją postrzegał Kelsen w RR1. Heidemann w tym kontekście zauważa, że powinność można uznać za analogiczną do kantowskiej kategorii relacji jako łącznik między dwoma stanami rzeczy ${ }^{90}$. Alexy stwierdza, że w celu odpowiedzi na pytanie, czy powinność może być relatywną kategorią a priori, trzeba wpierw określić rolę, jaką odgrywa ona w związku z normami. Powinność można w tym kontekście ujmować w sensie subiektywnym i obiektywnym. Powinność w sensie subiektywnym dotyczy norm pomyślanych przez kogokolwiek ${ }^{91}$. Takie normy nabierają prawnego znaczenia dopiero, gdy zostaną ustanowione przez odpowiedni organ. Wówczas powstaje powinność obiektywna. Sama powinność - według Alexego - może być rozumiana w trzech znaczeniach: powinności obowiązywania, obiektywnej powinności lub powinności jako słuszność (Richtigkeit). Każde z nich prowadzi do dwustopniowej struktury normatywności. Pierwszy stopień to jedynie zawartość myślowa, gdzie powinność jest pojęciem wolnym od obowiązywania. Alexy nazywa ją powinnością neutralną. Pomyślana norma staje się następnie przedmiotem aktu woli, a neutralna powinność zmienia się w subiektywną powinność ${ }^{92}$. Drugi stopień zaczyna się wraz z ustanowieniem określonego prawa przez kompetentny organ. Jednak, jak twierdzi Alexy, ten poziom obowiązywania nie wystarcza do tego, by można było mówić o doświadczaniu prawa. Obowiązywanie jest jedynie „zadaniem transcendentalnej kategorii”"93, która z subiektywnego ma uczynić obiektywne, natomiast nie jest rezultatem zastosowania kategorii. Alexy wskazuje, że kelsenowska definicja obowiązywania, oznaczająca zobowiązanie określonego człowieka do powinnego, wyrażonego w niej zachowania, może wskazywać, że wchodzi tu w grę obiektywna powinność. Skoro, zaznacza Alexy, obowiązywanie jest zdefiniowane jako zobowiązanie, a zobowiązanie jako powinność, to obowiązywanie jest powinnością. Oznaczałoby to jednak powtórzenie powinności (pierwszy

\footnotetext{
89 Ibidem.

${ }^{90}$ C. Heidemann, Die Norm als..., s. 56.

${ }_{91}$ Prawdopodobnie Alexy ma na myśli powinność w znaczeniu subiektywnym i obiektywnym.

92 R. Alexy, Hans Kelsens..., s. 195.

93 Ibidem, s. 196.
} 
raz powinność pojawiła się w charakterze aktu myślowego jako powinność subiektywna, by przekształcić się w powinność obiektywną). Alexy zadaje pytanie, czym jest ta podwójna powinność i czy taka konstrukcja znowu nie zbliża prawa do moralności ${ }^{94}$. Co zatem pozwala na doświadczenie prawne? Zostaje słuszność (Richtigkeit) polegająca na wypowiedzeniu sądu, co w danym systemie prawa (przy spełnieniu określonych przesłanek), zostało ustanowione jako powinność. Ten sąd związany jest z pytaniem o jego prawdziwość, który ma miejsce, jeżeli norma wypełnia kryteria obowiązywania (o charakterze normatywnym) systemu prawnego. Będą to: uchwalenie nomy w odpowiednim trybie oraz pewne minimum jej skuteczności. Obiektywna powinność jest zatem, według Alexego, możliwa pod warunkiem powiązania warunku prawnego, następstwa prawnego oraz wypełnienia kryteriów obowiązywania prawnego. Alexy konkluduje, że to powinność jako prawdziwość jest „kluczem” do prawa. Podsumowując, Alexy w swoich rozważaniach zwrócił uwagę na jeden dość istotny fakt: powinność jako taka nie może pełnić funkcji relatywnej kategorii a priori, ponieważ przy takim ujęciu nie da się odróżnić prawa od moralności. Pojęcie powinności w omawianej roli musi być uściślone i zawężone do wskazanych wyżej aspektów obowiązywania i słuszności. Koncepcja ta wydaje się jednak w bardziej oczywisty sposób wpasowywać w trzecią fazę, w której funkcjonuje podział na normy prawne i zdania prawne, gdzie pojęcie słuszności odnosiłoby się do zdań prawnych. $Z$ tej konstrukcji, moim zdaniem, wyłania się jeszcze inny wniosek. Obiektywna powinność jest możliwa tylko, wtedy, gdy ma miejsce zarachowanie i spełnione są kryteria obowiązywania. Jeśli jednak przyjmie się, że obowiązywanie to specyficzna egzystencja normy prawnej, to oznaczałoby, że w istniejących normach prawnych samo zarachowanie wyraża obiektywną powinność. Moim zdaniem, zarachowanie odpowiadałoby tu wewnętrznemu a priori, ponieważ dla niego nie jest wymagane dodatkowe, ,zewnętrzne” kryterium - obowiązywania.

Propozycja Alexego niezmiernie ciekawa, cechująca się kompleksowym podejściem, niewątpliwie posiada wiele zalet. Warto jednak powstrzymać się przed ostateczną konkluzją, dopóki nie zostaną zanalizowane dwa pozostałe stanowiska.

\subsubsection{Norma podstawowa jako relatywna kategoria a priori}

Zasadnicze pytanie, które można postawić podczas rozważań na temat normy podstawowej jako relatywnej kategorii a priori, dotyczy powodu, dla którego miałaby być kategorią w znaczeniu kantowskim. O ile łatwo zrozumieć, skąd $\mathrm{w}$ drugiej przesłance pojawiło się zarachowanie (na zasadzie analogii do kategorii przyczynowości) oraz powinności (tu analogia odnosi się do kategorii relacji), to obecność normy podstawowej nie jest już tak oczywista. Heidemann wprawdzie wskazuje, że Kelsen przyporządkowuje ją kategorii substancji, ponieważ tak jak

${ }^{94}$ Ibidem, s. 196-197. 
substancja w naturze, tak samo norma podstawowa na gruncie prawa konstytuuje trwałość (którą jest trwałość (Beherrlichkeit) państwa w czasie ${ }^{95}$ ), to jednak ta analogia nie jest samo narzucająca się. Kelsen o normie podstawowej w tym kontekście pisze w RR2:

norma podstawowa może zostać przedstawiona w nauce prawa - gdy się zastosuje per analogiam kantowską teorię poznania - jako transcendentalno-logiczny warunek [...] zakładając, że przyjmie się normę podstawową: powinno się tak zachowywać jak jest to zapisane w konstytucji [...] funkcją normy podstawowej jest: obiektywne obowiązywanie pozytywnego porządku prawnego [...], to znaczy: nadać znaczenie obiektywne subiektywnemu sensowi aktów ${ }^{96}$.

Heidemann podejmuje próbę rekonstrukcji toku myślenia Kelsena, wskazując, że zadaniem czystej teorii prawa jest analiza obiektywnie obowiązujących warunkowych zdań metodą transcendentalną. W rezultacie, Kelsen dochodzi do konkluzji, że obiektywizm tych zdań osiągnięty jest poprzez istnienie konstytucji, której podstawą jest norma podstawowa. Sama norma podstawowa jest logicznym warunkiem każdego prawdziwego zdania prawnego. Obowiązuje jedynie w sposób relatywny ${ }^{97}$, przez co jawi się jako kolejny aspekt obowiązywania (pierwszym była powinność). W przypadku normy podstawowej można zatem wyróżnić nieco inną wersję argumentu transcendentalnego, w której przesłanki byłyby następujące:

1. Prawo obowiązuje.

2. Jeśli prawo obowiązuje, to koniecznie jest założenie normy podstawowej.

3. Należy założyć normę podstawową.

Ta wersja znakomicie wyjaśnia, dlaczego Kelsenowi niezbędna była norma podstawowa (nie mógł uzasadnić prawa ani odwołując się do faktów, ani do prawa natury). Uwypuklony jest również dzięki temu związek obowiązywania, normy podstawowej i powinności.

Za podobną wersją argumentu transcendentalnego opowiada się na przykład Norbert Leser, wskazując na stwierdzenie Kelsena, że o ile w świecie bytu kategorie są warunkiem jego jedności w postrzeżeniach, o tyle w świecie powinności jedność prawa jest gwarantowana przez normę podstawową ${ }^{98}$. Leser argumentuje, że jeżeli norma podstawowa jest ,,formalnym uosobieniem wszystkich funkcji zarachowania"99, które mają strukturę

jeśli $a$, to powinno $b$,

${ }_{95}$ C. Heidemann, Die Norm als..., s. 97.

${ }_{96}$ RR2, s. 205.

97 C. Heidemann, Die Norm als..., s. 97.

${ }_{98}$ N. Leser, Die Reine Rechtslehre im Wiederstreit der philosophischen Ideen, Schriftenreihe des Hans Kelsen-Instituts, Wien 1982, s. 102.

99 Ibidem. 
to należy przyjąć, że jest ona jednocześnie hipotetyczną formą poznania prawnego. Jak należy to stwierdzenie rozumieć? Wydaje się, że można przyjąć że zarachowanie dotyczy pojedynczej normy prawnej, natomiast norma podstawowa jest kategorią bardziej ogólną i dotyczy wszystkich norm prawnych, całego prawa. Tylko dzięki niej obiektywne poznanie prawne może nabrać ważności, prawo można odróżnić od faktów i innych norm, niemających charakteru prawnego, ponieważ to ona nadaje wszystkim regułom normatywnym charakter prawa obiektywnie obowiązującego ${ }^{100}$. Norma podstawowa ma za zadanie dostarczyć warunki pozwalające na zebranie empirycznego materiału, należącego systemu prawnego, a następnie warunki dla możliwości poznania prawa jako apriorycznego obiektu ${ }^{101}$.

Koncepcja normy podstawowej jako kategorii, dzięki której możliwe jest poznanie prawne, rodzi problem dotyczący jej hipotetycznego charakteru ${ }^{102}$. To dość słaba podstawa nasuwająca na myśl związki z metafizyką, od której transcendentalizm przecież się odciął. Również odwołanie się do brzytwy Ockhama zakazującej mnożenia istnień ponad potrzebę nie działa na korzyść konstrukcji normy podstawowej. Kategorie Kanta w przeciwieństwie do kategorii normy podstawowej miały znacznie solidniejsze uzasadnienie. Kant był w stanie wykazać, że przedstawione przez niego warunki poznania są uniwersalne i dotyczą każdego przedmiotu. Kelsen ma zaś trudności z wykazaniem, dlaczego nauka prawa może być ważna wyłącznie jako normatywna nauka prawa. Jak słusznie zauważa Stefan Hammer, Kelsen, odrzucając tezę redukcyjną i tezę o związku, jest wręcz zmuszony do przyjęcia, że:

ten, kto aspiruje do traktowania prawa jako czegoś normatywnego, może to uczynić tylko, jeśli przyjmie założenie normy podstawowej w postaci kategorii normatywnej hipotetycznego sądu powinnościowego ${ }^{103}$.

Problem polega zatem na tym, że istnieją wątpliwości co do transcendentalnego charakteru normy podstawowej. Według Hammera, Kelsen przyjmuje za neokantystami jako punkt wyjściowy fakt nauki prawa. Dzięki temu, wszelkie przesłanki byłyby niekwestionowane, zaś a priori jawiłoby się jako niezbędny warunek nauki prawa. Pozwala to wprawdzie na wskazanie, że założenie normatywnej kategorii jest niezbędne, ponieważ w przeciwnym razie prawo nie mogłoby zostać rozpoznane i wyróżnione spośród innych przedmiotów badania, to jednak takie ujęcie, według Hammera, zredukowałoby rozważania do analizy określonej metody

100 S. Hammer, A Neo-Kantian..., s. 183-184; S.L. Paulson, Lässt sich..., s. 170, G. Luf, On Transcendental Import of Kelsen's Basic Norm, [w:] S.L. Paulson, B. Litschewski-Paulson (Hrsg.), Normativity..., s. 224.

${ }^{101}$ G. Luf, On Transcendental Import of Kelsen's Basic Norm, [w:] S. L. Paulson, B. Litschewski-Paulson (Hrsg.), Normativity..., s. 224.

102 S. Hammer, A Neo-Kantian..., s. 185.

103 Ibidem, s. 186. 
i w żaden sposób nie uzasadniałoby argumentu dotyczącego wiedzy jako danej ${ }^{104}$. Jak widać, jest to raczej zarzut odnoszący się do samej struktury argumentu transcendentalnego. Jednak Hammer wskazuje, że problem z normą podstawową tkwi również w innym miejscu ${ }^{105}$. Punktem wyjścia dla transcendentalnych rozważań u Kelsena może być zestawienie ze sobą teorii wiedzy empirycznej i teorii wiedzy prawnej. Jeżeli normy prawne byłyby dane w ten sam sposób co materiał wiedzy empirycznej, to, według Kelsena, nie można byłoby ich określić normami, a nauka prawa nie byłaby nauką normatywną ${ }^{106}$. Rozwiązaniem tego problemu może być stwierdzenie (które pojawiło się już u Alexego), że normy prawne są rozpoznawane na mocy faktów, które poddają się interpretacji normatywnej, dokonującej się na mocy zarachowania. Ponadto, Hammer zauważa, że norma podstawowa jako kategoria zarachowania i spełniająca warunki dla nauki prawa pozytywnego jest kategorią pustą. Żeby można było odróżnić naukę prawa od innych nauk normatywnych, na przykład teologii, to musi ona zostać wzbogacona o inne elementy (kryteria). Według Hammera, takimi kryteriami mogą być: wydanie prawa w odpowiednim trybie oraz odpowiedni stopień jego skuteczności. W ten sposób wzbogacona norma podstawowa pozwalałaby na identyfikację faktów, które mogą być zinterpretowane jako normy prawa pozytywnego (akty woli, które ujawniają formę hipotetycznego powinnościowego sądu i są w dostatecznym stopniu efektywne). W rezultacie, dzięki normie podstawowej kategoria zarachowania może być zastosowana do aktów woli, które mają formę hipotetycznego sądu powinnościowego. To pozwala na dostrzeżenie, że normatywność aktów leży w procesie ich tworzenia, łączącego powinność i materialny fakt.

W związku z tym, ważność pojedynczej normy prawnej, która tworzy takie połączenie, jawi się jako konsekwencja prawna normy wyższego rzędu. Jest to nic innego jak zasada delegacji, która powoduje, że kategoria zarachowania dwuelementowa może zostać rozszerzona o całą serię delegacji ${ }^{107}$. Pytanie, które od razu się nasuwa, wiąże się z typem zarachowania przy takiej konstrukcji. Jak wiadomo, zarachowanie peryferyjne dotyczy faktu warunkującego zastosowanie sankcji z samą sankcją, natomiast zarachowanie centralne wiąże określony fakt z podmiotem, którym jest państwo. Wydaje się, że w tym drugim przypadku zarachowanie może pełnić rolę schematu dla łańcucha delegacji teoretycznie rozszerzanego w nieskończoność. Należy jednak zwrócić uwagę, że takie ujęcie o wiele bardziej upodabnia kategorię zarachowania do kategorii przyczynowości. Wątpliwości może też budzić powoływanie się Hammera na skuteczność i sferę faktów. Moim zdaniem, Hammer położył zbyt silny nacisk na powiązanie faktów i sfery normatywnej.

\footnotetext{
${ }^{104}$ Ibidem, s. 186-188.

105 Ibidem, s. 188.

106 Ibidem.

107 Ibidem, s. 188-191.
} 
Interesującego argumentu przeciw normie podstawowej dostarcza Alexy. Według niego, aby można było uznać, że norma podstawowa jest relatywną aprioryczną kategorią, to powinno być z nią związane coś, co: po pierwsze, ma charakter przesądzający dla problemu normatywności; po drugie, wykracza poza granice zaabsorbowanej w zarachowaniu powinności. Jednak tak nie jest, ponieważ norma podstawowa z punktu widzenia normatywności jest jedynie „powinnością w usystematyzowanej formie" ${ }^{108}$. Alexy uzasadnia to w następujący sposób. Ze względu na to, że hipotetyczny charakter wynika z formy zdania warunkowego (połączenia warunku prawnego z następstwem prawnym), to modalnością tego połączenia jest powinność, czyli ta sama konstrukcja, która została omówiona powyżej wzbogacona o element dynamiczny. W przypadku normy podstawowej normatywność objawiająca się w kategorii powinności dotyczy nie każdej pojedynczej normy, ale tylko tej jednej, na czubku piramidy systemu prawnego. Norma podstawowa według Alexego ,zasila normatywność jednym aktem”109. Innymi słowy, w kontekście zagadnienia poznania prawnego, zastosowanie normy podstawowej jest systemowym warunkiem kategorii powinności.

Następny problem, na który wskazuje Alexy, sprowadza się do jej bezwarunkowego charakteru. Jest on konieczny, ponieważ w przeciwnym razie nie dałoby się prawa ując jako przedmiotu poznania, co nieuchronnie naraziłoby tę konstrukcję na zarzut jej metafizyczności. Ostatecznie, albo norma podstawowa nabiera metafizycznego charakteru, albo jest jedynie arbitralnym założeniem, a żadne $\mathrm{z}$ tych rozwiązań nie jest satysfakcjonujące ${ }^{110}$. Zgadza się z tym Hammer, wskazując, że w odróżnieniu od transcendentalnych kategorii, dzięki którym można poznać świat naturalny, norma podstawowa musi również stworzyć swój obiekt - świat normatywny. W przeciwnym razie, w ogóle nie byłby on dany poznaniu prawnemu. W rezultacie, takiego obiektu nie da się sfalsyfikować, co powoduje, że stając się „obiektem wyobraźni”, nabiera on metafizycznego charakte$\mathrm{ru}^{111}$. Hammer konkluduje, że ustanowienie normy podstawowej jako centralnego elementu transcendentalnej teorii poznania prawa wydaje się być niemożliwe ${ }^{112}$.

Paulson z kolei proponuje inne ujęcie, w którym norma podstawowa zawiera w sobie transcendentalną argumentację, którą można zrekonstruować, wprowadzając odpowiednią transcendentalną kategorię (w tym wypadku zarachowanie). W ten sposób norma podstawowa zostałaby zredukowana do terminu technicznego, za pomocą którego argument transcendentalny w ogóle może zostać przeprowadzony ${ }^{113}$. Należy jednak zauważyć, że przy takim ujęciu rozbieżnością jest samo sformułowanie argumentu transcendentalnego i pytanie, czy bardziej adekwatne

\footnotetext{
108 R. Alexy, Hans Kelsens..., s. 191.

109 Ibidem, s. 192.

110 Ibidem, s. 191-192.

111 S. Hammer, A Neo-Kantian ..., s. 191-193.

112 Ibidem.

113 S.L. Paulson, Lässt sich..., s. 170.
} 
jest umiejscowienie go w drugiej przesłance zarachowania czy też od razu normy podstawowej. Za zarachowaniem przemawia to, że jest ono kategorią analogiczną wobec przyczynowości, a więc jego wybór sam się nasuwa. Natomiast na korzyść normy podstawowej przemawia fakt, że ujmuje materiał prawny w jedną całość.

Z powyższych rozważań wydaje się wynikać, iż o ile zarachowanie dotyczy raczej poznania pojedynczych norm prawnych, o tyle norma podstawowa - poznania prawa jako całości. Jednak zarówno norma podstawowa, jak i zarachowanie peryferyjne pozwalają na odróżnienie prawa od innych nauk prawnych.

Skoro z rozważań dotyczących normy podstawowej wynika jej powiązanie z zarachowaniem, to czas je omówić, by następnie podjąć próbę podsumowania.

\subsubsection{Zarachowanie jako relatywna kategoria a priori}

Na pierwszy rzut oka trudno jest u Kelsena znaleźć fragment, w którym relatywna kategoria a priori zostałaby ujęta w postaci zarachowania. Zarówno w przypadku normy podstawowej, jak i powinności wystarczy zajrzeć do spisu treści odpowiednio RR2 i RR1, by zauważyć podrozdziały przyporządkowujące im funkcje kategorii transcendentalnej. Jednak jeśli się wczytać w treść RR1, to można zauważyć, że jest to wrażenie błędne. Kelsen w podrozdziale o powinności jako kategorii transcendentalnej pisze:

norma prawna jest rozumiana jako sąd hipotetyczny, w którym wyraża się specyficzne powiązanie warunkowego faktu i warunkowego następstwa. [...] zarachowanie jest rozumiane jako szczególna normatywność prawa. [...] Wyrazem powiązania wskazanego jako „zarachowanie” i tym samym wyrazem specyficznej egzystencji prawa, jego obowiązywania [...] jest powinność [...], tak jak wyrazem powiązań przyczynowych jest konieczność. [...] Powinność jest [...] relatywną aprioryczną kategorią ${ }^{114}$.

Co z przytoczonego fragmentu wynika? Wydaje się, że Kelsen wskazuje na wtórność powinności, gdy rozpatruje się ją w relacji do zarachowania peryferyjnego. Jest ona jego „wyrazem”. Jeśli posłużyć się analogią z kantowską aprioryczną kategorią przyczynowości, to warto zauważyć, że to właśnie przyczynowość, będąca odpowiednikiem zarachowania, a nie konieczność, będąca odpowiednikiem powinności spełnia tę funkcję. Jednym $\mathrm{z}$ autorów ujmujących rolę zarachowania jako relatywnej kategorii a priori, analogicznie do kategorii przyczynowości umożliwiającej poznanie natury, jest Günter Winkler. Alogiczny materiał prawny zatem może być poznany przez kategorię zarachowania ${ }^{115}$ : Jak jednak rozumieć ową analogiczność? Heidemann wskazuje, że analogia wynika z neokantowskiego pojęcia sądów syntetycznych. Pełnią one konstytutywną rolę w poznaniu, a ich specyfika polega na tym, że ich ważność wynika ze zgodno-

114 RR1, s. 33-35.

115 G. Winkler, Rechtstheorie und Erkenntnislehre, Springer Verlag, Wien, New York 1990, s. 76. 
ści z regułami poznania. Natura jest zatem zbiorem powiązanych ze sobą sądów dotyczących poznania, w których zastosowana jest kategoria przyczynowości. W nauce prawa, rozumianej jako system sądów o prawie (z prawem tożsamych), kategoria powinności (zarachowania) jest stosowana wobec alogicznego materiału powstałego na mocy aktu woli prawodawcy, pozbawionego charakteru normatywnego ${ }^{116}$. Samo pojęcie zarachowania jako relatywnej kategorii a priori ma przede wszystkim charakter formalny, czyli niedotyczący treści prawa, w szczególności rzeczywistości społecznej.

Analogiczny wobec przyczynowości charakter zarachowania, według Alexego, można rozpatrywać na dwóch płaszczyznach ${ }^{117}$ : transcendentalnej i logicznej. Na płaszczyźnie transcendentalnej zarachowanie i przyczynowość występują właśnie jako aprioryczne kategorie. Płaszczyzna logiczna dotyczy logicznej struktury sensu largo, która powinna funkcjonować jako kategoria analogiczna do przyczynowości. Poza tym, zauważa Alexy, analogia między przyczynowością a zarachowaniem pełniących funkcję apriorycznej kategorii opiera się na podobieństwach i różnicach (rodzaj najbliższy i różnica gatunkowa). Podobieństwem jest to, że norma jest określana przez Kelsena jako hipotetyczny sąd. Kant z kolei opisuje kategorię przyczynowości jako czyste pojęcie intelektu, logiczną funkcję sądu hipotetycznego, czyli relację przyczyny do następstwa. W ten sposób przyczynowość zalicza się do grupy form sądów. Różnica gatunkowa odnosi się do modalności: powinności i konieczności. W przypadku faktyczności zachodzi konieczność (jeśli A to musi być B), natomiast w przypadku prawa powinność. Jednak przy takim ujęciu powinności brakuje rozdziału prawa i moralności na płaszczyźnie formalnej. Jak wskazuje Alexy, nasuwają się zatem poważne wątpliwości, czy zarachowanie może ustanawiać szczególną autonomię prawa, czy $\mathrm{w}$ tej sytuacji zarachowanie nie jest tylko warunkiem i operatorem ${ }^{118}$.

Moim zdaniem, ten zarzut łatwo odeprzeć odwołując się do rozróżnienia pomiędzy zarachowaniem peryferyjnym a zarachowaniem klasycznym. W istocie, zarachowanie klasyczne, łącząc stan faktyczny z adresatem, jest wspólne zarówno dla moralności, jak i prawa. Jednak zarachowanie peryferyjne, łączące stan faktyczny z sankcją i przymusem, charakteryzuje już tylko prawo. Powiedzieć, że różnicą gatunkową jest powinność to za mało. Należy pójść dalej i wskazać elementy, które łączy powinność. Jednym z nich jest przymus, którego nie ma w normach moralnych. Nawiązując do słów Alexego, kategoria zarachowania w przeciwieństwie do przyczynowości nie posiada charakteru uniwersalnego, jest relatywna. Według Paulsona, relatywizacja w tym przypadku polega na tym, że jeśli chce się „grać w grę prawną" 119 , to kategoria zarachowania jest niezbędna, wówczas bowiem należy uznać istnienie dualizmu bytu i powinności oraz

\footnotetext{
116 C. Heidemann, Geltung und..., s. 213.

117 R. Alexy, Hans Kelsens..., s. 184.

118 Ibidem, s. 185.

119 S.L. Paulson, Die Zurechnung..., s. 112.
} 
wszelkich konsekwencji owego podziału. Jednak, jak wskazuje Paulson, w tę grę grać nie trzeba. Przykładem może być teoretyczny anarchizm, według którego prawo nie jest niczym innym jak przemocą.

Z przedstawionych rozważań wynika, że najwięcej zarzutów można sformułować pod adresem rozwiązania najczęściej proponowanego przez Kelsena: normy podstawowej. Pozostają zatem zarachowanie oraz powinność. Wydawałoby się, że wiele przemawia za uznaniem powinności za relatywną kategorię a priori. Jednak warto przytoczyć krytykę Paulsona, który zwraca uwagę, że takie ujęcie miałoby jeden zasadniczy mankament: „Sollen” używane jest u Kelsena $\mathrm{w}$ wielu znaczeniach, nie jest również sprecyzowane. Zatem trudno tu o konkretne odpowiedzi na różnorodne pytania, na przykład, jaką funkcję pełni. Pod tym względem - twierdzi Paulson - zarachowanie zdecydowanie przewyższa powinność ${ }^{120}$. Moim zdaniem, ów argument jednak nie wydaje się trafny. Kelsen wyraźnie sprecyzował, w jakim sensie powinność jest rozumiana jako kategoria transcendentalna, czyli że jest wyrazem zarachowania, co tym bardziej przechyla szalę na korzyść tego drugiego. Wydaje się zatem, że to zarachowanie daje najpełniejszy obraz tego, czym jest argument transcendentalny w normatywizmie, a co za tym idzie obraz całej teorii Kelsena z czasów pierwszego wydania $C z y s t e j$ teorii prawa. Takie ujęcie zapewnia spójną wizję argumentu transcendentalnego, w którym centralną rolę odgrywa zarachowanie. Norma podstawowa decyduje o relatywizacji tej kategorii do sfery prawa, zaś słowo „powinien” to gramatyczny jego wyraz. Przemawia za nim również wspominany już argument, że u Kanta ujmowanie zjawisk jest możliwe dzięki kategorii przyczynowości, analogicznej do zarachowania. Tak jak przyczynowość, zarachowanie nie jest dane doświadczeniu, a jego ważność nie zależy od dowodów o charakterze empirycznym i jest warunkiem możliwego doświadczenia ${ }^{121}$. Warto również zauważyć, że zarówno normę podstawową, jak i powinność ostatecznie można zredukować do zarachowania. Wydaje się zatem, że ze wszystkich „kandydatów” na relatywną kategorię a priori to właśnie zarachowanie oferuje koncepcję najbardziej spójną.

Pozostaje jednak jeszcze jedna kwestia: u Kanta przyczynowość nie jest jedyną aprioryczną kategorią. Jest jedną z dwóch wyróżnionych (drugą jest substancja), a jeszcze poza nimi można wyróżnić cały katalog innych kategorii. Dlaczego zatem nie uznać, że w przypadku czystej teorii prawa na kategorię transcendentalną nadaje się zarówno norma podstawowa, powinność, jak i zarachowanie? Moim zdaniem, na to pytanie należy udzielić następującej odpowiedzi: przedstawiona wyżej analiza wykazała z jednej strony sposób, w jaki te trzy kategorie są ze sobą powiązane (każdą w jakiś sposób można sprowadzić do zarachowania), a z drugiej strony, trudności, które napotyka się, przeprowadzając analogię w tym zakresie między Krytyka czystego rozumu a Czysta teoria prawa. Analogia

\footnotetext{
${ }^{120}$ Ibidem, s. 115.
}

121 J. Renzikowski, Der Begriff..., s. 254; za zarachowaniem jako relatywnej kategorii a priori opowiada się również Winkler: G. Winkler, Rechtstheorie..., s. 76-77. 
ta wskazuje na pewne podobieństwa, a nie identyczność poddawanych analizie przypadków. W konsekwencji, różnice nie muszą być czynnikiem dyskwalifikującym (choć mogą), zaś analogią bardziej trafną jest ta, przy której tych różnic jest jak najmniej. W przypadku normy podstawowej i powinności analogia wydaje się po prostu mniej trafna aniżeli w przypadku zarachowania. $Z$ pewnością jednak nie jest to sytuacja „wszystko albo nic”. Każdy z trzech „kandydatów” może zostać osadzony w roli relatywnej kategorii a priori.

Na koniec warto postawić pytanie, czy w świetle tych wszystkich niespójności argument transcendentalny w czystej teorii prawa jest koncepcją bezwartościową? Wydaje się, że należy udzielić na nie odpowiedzi przeczącej. Po pierwsze, ta koncepcja ujawnia ważny aspekt struktury kelsenowskiej teorii oraz powiązania między pojęciami, które na pierwszy rzut oka oznaczają coś innego. Po drugie, sprawia, że to właśnie czysta teoria prawa, z tego okresu jest uznawana za najbogatszą intelektualnie i stanowi inspirację dla szerokiego grona badaczy. Po trzecie, ma tu zastosowanie wspominany wcześniej argument dotyczący specyfiki nauk humanistycznych, w szczególności filozofii, gdzie trudno jest wskazać koncepcję nie zawierającą niespójności i niedociągnięć. Praktycznie każda z nich jest przedmiotem krytyki, ale właśnie owa krytyka jest miarą wartości określonej myśli filozoficznej, ponieważ wchodzi w skład heglowskiej dialektyki: tezy-antytezy i syntezy. Nawiązując do przytoczonych wcześniej słów Dore’a, zawodność argumentu transcendentalnego nie przesądza o wartości czystej teorii prawa, a jedynie znosi jej roszczenie do wyłączności.

\subsection{Zarachowanie centralne}

W drugiej fazie Kelsen dokonał podziału na omówione wcześniej zarachowanie peryferyjne oraz zarachowanie centralne. Opisuje on operację zarachowania centralnego, posługując się znanymi z pierwszej fazy pojęciami. I tak państwo jako najwyższa wola jest końcowym punktem zarachowania, tym samym gwarantując jedność porządku prawnego ${ }^{122}$. Kelsen twierdzi przy tym, że pojęcie osoby (w sensie praw i obowiązków) jest tożsame z pojęciem jedności tych norm, które regulują zachowania osób, zaś w przypadku państwa, jest ono tożsame z całością systemu prawnego ${ }^{123}$. Osoba jest więc, tak jak w poprzedniej fazie, punktem zarachowania ${ }^{124}$. Pojawiają się jednak nowe elementy, na przykład twierdzenie, że najwyższa, niczym nieskrępowana wola państwa jako końcowy punkt zarachowania jest znamieniem suwerenności. W tym sensie zarachowanie wiąże się

122 H. Kelsen, Grundriß einer allgemeinen Theorie des Staates, Wien 1926, s. 71; RR1, s. 69; H. Kelsen, Gott und Staat, „Logos. Internationale Zeitschrift für Philosophie der Kultur“, 23 XI 1922, Nr 3, s. 277.

${ }^{123}$ C. Heidemann, Der Begriff der..., s. 22.

124 ASL, s. 65, 71. 
z wolnością woli, podczas gdy przyczynowość z determinizmem. Osoba jest wolna, ponieważ tak jej to zarachowano ${ }^{125}$. Zarachowanie centralne w fazie klasycznej odgrywa również nową rolę w stosunku do fazy poprzedniej, jest bowiem związane z zaadaptowaną przez Kelsena Merklowską konstrukcją hierarchiczną budową porządku prawnego (Stufenbau ${ }^{126}$. Kelsen w swoje rozważania włącza teraz zagadnienia wcześniej odrzucone, to jest tworzenia prawa. Dzięki temu zarachowanie centralne, mimo że definiowane podobnie, nabiera nieco innego znaczenia, w którym pojęcie sankcji praktycznie zanika. Dzięki temu o wiele wyraźniej zarysowuje się różnica między zarachowaniem peryferyjnym a centralnym. Wydaje się zatem, że dla przeanalizowania roli zarachowania centralnego niezbędne jest wyjaśnienie hierarchicznej struktury norm prawnych w ujęciu dynamicznym. W HP Kelsen nie wspomina o systemie dynamicznym, jednak już w przedmowie do wydania II rozprawy wyraża się o tym fakcie krytycznie. Zauważa, że zbyt dużo uwagi poświęcił normom generalnym, przez co pominął całe spektrum norm, które umiejscowione są pomiędzy normą generalną a konkretnym aktem stosowania prawa. Lukę tę miała wypełnić właśnie koncepcja Adolfa Merkla dotycząca hierarchiczności ${ }^{127}$. Merkl wskazuje na kilka poziomów norm. Po pierwsze, na normy nakładające na podmioty obowiązek zgodnego z nimi zachowania. Na tym poziomie nie da się stworzyć nowego prawa, brakuje bowiem odpowiednich norm regulujących tę kwestię, a co za tym idzie organów, które mogłyby prawo tworzyć. Merkl wprowadza zatem drugi poziom, zawierający normy upoważniające. Mamy więc punkt widzenia dynamiczny, polegający na wydaniu normy, oraz statyczny, czyli normę wydaną. Jednak taki system wciąż zawiera braki, mianowicie brak jest norm stosowania prawa. Zostaje on usunięty poprzez wprowadzenie trzeciego poziomu, jakim jest stosowanie prawa. W ten sposób system prawa staje się dynamiczny, ponieważ normy, poza przypadkami skrajnymi, którymi są tzw. norma pierwotna (Ursprungnorm) jako punkt początkowy oraz akt egzekucyjny jako punkt końcowy, pełnią rolę zarówno norm tworzących prawo, jak i norm stosowania prawa.

Merkl na tym nie poprzestaje, ograniczając się jedynie do dwóch funkcji prawa - tworzenia i stosowania (indywidualizacja normy generalnej), pomijając najbardziej pierwotną, czyli nakazującą określone postępowanie ${ }^{128}$. Jak wskazuje Paulson, oznacza to, że norma prawna jest ważna, jeżeli należy do systemu prawa i jeśli istnieje norma wyższego rzędu, która zawiera upoważnienie do jej ustano-

125 Ibidem, s. 71-72.

126 Zob. A. Merkl, Prolegomena einer Theorie der Rechtlichen Stufenbaues, [w:] H. Klecatsky, R. Marcić, H. Schambeck (Hrsg.), Die Wiener..., s. 1311-1361.

127 S.L. Paulson, On the Implication of Kelsen's Doctrine of Hierarchical Structure, ,The Liverpool Law Review“ 1996, vol. XVIII(1), s. 53; M. Borowski, Die Lehre vom Stufenbau des Rechts nach Adolf Merkl, [w:] S.L. Paulson, M. Stolleis (Hrsg.), Hans Kelsen Staatsrechtslehrer und Rechtstheoretiker des 20. Jahrhunderts, Grundlagen der Rechtswissenschaft, Mohr Siebeck, Tübingen 2005, s. 156.

128 A. Merkl, Prolegomena..., s. 1335-1350; M. Borowski, Die Lehre..., s. 131-135. 
wienia $^{129}$. Norma wyższego rzędu spełnia dwie funkcje w zależności od tego czy mamy do czynienia z momentem przed wydaniem normy niższego rzędu, czy już po. Przed wydaniem normy niższego rzędu norma hierarchicznie wyższa jest normą upoważniającą. Po wydaniu stanowi kryterium obowiązywania normy niższego rzędu. Merkl nazywa te normy warunkującą i zawarunkowaną. Priorytet normy warunkującej wynika nie tylko z temporalnego aspektu, ale również logicznego ${ }^{130}$.

Kelsen przejął wiele z merklowskiej koncepcji. Używa on wyrażeń „statyczny” i „dynamiczny”, by odróżnić dwa typy systemów norm prawnych. W przypadku porządku statycznego mamy do czynienia z powiązaniami treściowymi. $Z$ punktu widzenia obowiązywania istotne jest wtedy to, co zawiera norma hierarchicznie wyższa. Jak wskazuje Opałek, sposób powstawania norm w takim systemie opiera się na dedukcji, wynikając właśnie z charakteru powiązań ${ }^{131}$. W systemie dynamicznym treść nie ma większego znaczenia - a ważne jest upoważnienie zawarte w normie wyższego rzędu. To prowadzi do stwierdzenia, że prawo samo reguluje sposób jego tworzenia, poczynając od konstytucji, poprzez ustawy, kończąc na aktach niższego rzędu, aż do punktu skrajnego, czyli indywidualnego aktu stosowania prawa ${ }^{132}$. Z punktu widzenia normy wyższego rzędu, wydanie normy rzędu niższego jest stosowaniem prawa, natomiast z punktu widzenia normy niższego rzędu wydanie normy jest tworzeniem prawa ${ }^{133}$. Rezultatem tego zabiegu jest, jak wskazuje Paulson, relatywizacja różnicy pomiędzy tworzeniem a stosowaniem prawa ${ }^{134}$. W konsekwencji Kelsen za Merklem tworzy pojęcie pełnej normy prawnej jako kontrastu wobec normy generalnej, która jest niepełna i wymaga uzupełnienia ${ }^{135}$.

Jak wskazuje Martyniak, zatarcie różnicy miedzy tworzeniem i stosowaniem prawa jest widoczne na poziomie norm indywidualnych. Tradycyjnie są one postrzegane jako normy stosowania prawa, jednak u Kelsena wyrok sądowy czy decyzja organów administracyjnych o charakterze konstytutywnym tworzą nowy konkretny stosunek prawny, będąc tym samym „dalszym ciągiem tworzenia prawa"136. Prawo może się indywidualizować przez działanie samych stron zainteresowanych, na przykład przez zawarcie umowy. Ostatnim etapem w tej konstrukcji jest zastosowanie przymusu ${ }^{137}$.

Sławomira Wronkowska zwraca z kolei uwagę na przeoczenie Kelsena dotyczące charakteru nadrzędności jednej normy nad drugą. Ów charakter wyraża się

129 S.L. Paulson, On the Implication..., s. 55.

130 Ibidem, s. 108, 109; M. Borowski, Die Lehre..., s. 133-134.

${ }^{131}$ K. Opałek, Studia..., s. 83.

132 RR1, s. 73-76; H. Kelsen, Die philosophischen Grundlagen..., s. 240-241.

133 RR1, s. 92-93; S.L. Paulson, On the Implication..., s. 53.

134 S.L. Paulson, On the Implication..., s. 54.

135 Ibidem, s. 54, 56.

${ }^{136}$ C. Martyniak, Moc obowiazujaca prawa a teoria Kelsena, [w:] C. Martyniak, Dzieła, red. ks. R. Charzyński, M. Wójcik, Wydawnictwo KUL, Lublin 2006, s. 211.

137 Ibidem. 
nie tylko poprzez rodzaj aktu normatywnego, ale przede wszystkim w roli, którą dana norma spełnia, będąc aktem konwencjonalnym. Jednak to właśnie m.in. Kelsen utorował drogę tym późniejszym spostrzeżeniom ${ }^{138}$.

$\mathrm{Na}$ zakończenie tych rozważań warto zwrócić uwagę na ciekawe spostrzeżenie Ebensteina, który twierdzi, że teoria hierarchiczności spełnia istotną rolę w łączeniu dwóch sprzecznych tendencji: tendencji mającej miejsce w systemie civil law, kładącej nacisk na ustawy jako główne źródło prawa, oraz common law definiującego prawo przez pryzmat sędziowskich decyzji (law in books i law in action ${ }^{139}$. Teoria hierarchiczności wskazuje, że oba aspekty są równie ważne, że poza punktami granicznymi każdy akt może być zarówno rozpatrywany pod kątem tworzenia, jak i stosowania prawa.

W tym miejscu warto dokonać małego podsumowania, ponieważ moim zdaniem, dynamiczna struktura prawa, to w pewnym sensie jeden z najbardziej udanych elementów czystej teorii prawa. Koncepcja ta znakomicie odzwierciedla strukturę i istotę prawa. Kelsenowi często sie zarzuca, że popada on w błędne koło (definiując prawo jako zbiór norm, których cechą charakterystyczną jest przymus, a przymus - by uniknąć paradoksu bandyty - Kelsen wiąże z państwem, a państwo z prawem). Wydaje mi się, że jeśli w tych wyjaśnieniach uwzględni się dynamiczną strukturę prawa, to błędnego koła nie ma. Ponadto, warto zauważyć, że to właśnie dynamiczna struktura prawa i jego systemowość mogą stanowić differentiae specificea norm prawnych. Jeśli więc przyjmiemy arystotelesowską koncepcję poznania, gdzie poznanie łączy się z definiowaniem, to odpowiedź na pytanie o rolę systemowości prawa w jego poznaniu może być tylko jedna: właśnie dynamiczna struktura prawa może być odpowiedzią na pytanie, co odróżnia normy prawne od innych norm, szczególnie moralnych. W normach moralnych nie będzie wielopoziomowych formalnych powiązań między normami, nie będzie też delegacji kompetencji.

Aby wyjaśnić relacje między dynamiczną strukturą prawa a zarachowaniem centralnym, warto najpierw zadać pytanie, jak ten obraz prawa nakreślony przez Merkla i Kelsena ma się do rozważań zaprezentowanych wcześniej. Odpowiedzi na to pytanie udziela Paulson, wskazując, że dynamiczna perspektywa dotyczy raczej sytuacji przed wydaniem normy prawnej, natomiast statyczna po jej wydaniu $^{140}$. Paulson twierdzi również, że aby wpasować koncepcje Merkla we własną teorię, Kelsen rezygnuje z zarachowania centralnego i wprowadza zarachowanie peryferyjne, które wyobraża horyzontalne powiązania między normami. Teoria hierarchiczności odzwierciedla powiązania wertykalne, zastępując tym samym zarachowanie centralne ${ }^{141}$. Heidemann nazywa takie ujęcie krytycznym

138 S. Wronkowska, Posłowie, [w:] H. Kelsen, Istota i rozwój sądownictwa konstytucyjnego, Wydawnictwo Trybunału Konstytucyjnego, Warszawa 2009, s. 74.

139 W. Ebenstein, The Pure..., s. 645.

140 S.L. Paulson, On the Implication..., s. 55.

141 S.L. Paulson, Hans Kelsen's..., s. 811. 
ze względu na jego związki z transcendentalizmem ${ }^{142}$. Rezygnacja z zarachowania centralnego jest możliwa dzięki relatywnej kategorii a priori. Uzasadnienie obowiązywania normy prawnej ma wówczas charakter logiczny, opiera się bowiem na twierdzeniu, że z powinności może logicznie wynikać inna powinność. Zabieg ten sprowadza się do zastosowania kategorii powinności na empiryczny substrat, nadając mu tym samym znaczenie normatywne. Według Heidemanna, takie ujęcie jest jednak wbrew intencji Kelsena, mimo że znakomicie wpasowuje się w transcendentalne tło czystej teorii prawa ${ }^{143}$.

Zupełnie inaczej relacje pomiędzy zarachowaniem centralnym a powiązaniami dynamicznymi w prawie postrzega Renzikowski. Według niego, ten rodzaj zarachowania odegrał niebagatelną rolę dla opisania, na czym polegają hierarchiczne powiązania o charakterze dynamicznym ${ }^{144}$. Zarachowanie centralne odgrywa tu rolę konkretyzacji jedności porządku prawnego gwarantowanej przez normę podstawową. Konkretyzacja polega na związku normy z państwem, które jest jednością zarachowania jako jego punkt końcowy. Renzikowski wskazuje ponadto, że jeżeli norma jest rozumiana jako sens aktu woli, to normą prawną może być tylko wówczas, jeśli może zostać zarachowana państwu. W takim przypadku określone działanie ludzkie zostanie zinterpretowane jako działanie państwa ze względu na zarachowanie tego zachowania państwu. Wynika z tego oczywisty wniosek, że prawo samo reguluje jego tworzenie, a powiązania hierarchiczne zarachowania korelują z powiązaniami hierarchicznymi prawa w tym sensie, że powiązania hierarchiczne prawa są przyporządkowanymi następstwami zarachowania centralnego ${ }^{145}$. Za uznaniem, że Kelsen nie zrezygnował z zarachowania centralnego przemawiają jego słowa:

żeby państwo [było postrzegane] jako [...] podmiot tych stanów faktycznych, to można to osiągnąć tylko poprzez umysłową operację, zwaną tutaj zarachowaniem ${ }^{146}$.

Wydaje się, że należy zatem przyjąć interpretację Renzikowskiego.

\subsection{Relacje zachodzące między zarachowaniem centralnym a peryferyjnym}

Na koniec warto odpowiedzieć na pytanie, jakie są relacje między zarachowaniem peryferyjnym a centralnym, rozpoczynając od wskazania różnic. Kelsen łączy zarachowanie centralne z państwem, którego wola jest końcowym punktem i wskazuje, że:

142 C. Heidemann, Die Norm als..., s. 87.

143 Ibidem, s. 88.

144 J. Renzikowski, Der Begriff..., s. 265-266.

145 Ibidem, s. 267.

146 H. Kelsen, Grundriß..., s. 11. 
Jeśli ujmuje się prawo jako wolę państwa, to przede wszystkim ma się na uwadze aparat przymusu. Przez to chce się wyrazić, że prawo jest normą zawierającą element przymusu.

„Wola państwa” oznacza [...] wolę do [stosowania] przymusu [...] To, że państwo „chce” aktu przymusu, oznacza, że ten stan faktyczny jest w systemie prawa ustanowiony, tzn. powinny $\mathrm{z}$ punktu widzenia prawa ${ }^{147}$.

Z kolei w ASL Kelsen definiuje zarachowanie centralne jako:

związek stanu faktycznego i jedności porządku prawnego albo części porządku prawnego [...]. Różni się ono od wcześniej przedstawionego [...] o tyle, że tamto łączyło dwa stany rzeczy wewnątrz normy [...], podczas gdy powiązanie stanu rzeczy z jednością porządku [prawnego], wyraża system norm prawnych [...]. Zarachowanie peryferyjne prowadzi od jednego stanu rzeczy do drugiego, podczas gdy centralne do osoby (ale nie człowieka) ${ }^{148}$.

Podczas opisu zarachowania peryferyjnego zostało wspomniane, że połączenie warunku $\mathrm{z}$ następstwem $\mathrm{w}$ postaci aktu przymusu tak naprawdę odnosi się do całego łańcucha warunków, które muszą być spełnione, aby można było wykonać akt przymusu. Akt przymusu jest zatem ostatnią fazą procesu tworzenia prawa, który rozpoczyna się na poziomie prawa konstytucyjnego ${ }^{149}$. Na podstawie przedstawionego cytatu można zaryzykować stwierdzenie, że o ile w ostatnim ogniwie ma miejsce zarachowanie peryferyjne, to we wcześniejszych jest to zarachowanie centralne. Na inną różnicę wskazuje Martyniak, twierdząc, że o ile w zarachowaniu centralnym punktem zarachowania jest osoba, o tyle, w zarachowaniu peryferyjnym takim punktem jest stan faktyczny ${ }^{150}$.

Na podstawie przedstawionych różnic można wywnioskować, w jaki sposób zarachowanie centralne jest powiązane z peryferyjnym. Renzikowski zauważa, że zarachowanie peryferyjne dotyczy powiązań horyzontalnych, natomiast zarachowanie centralne powiązań wertykalnych. Norma zawierająca sankcję, czyli odnosząca się do zarachowania peryferyjnego, jest zarazem normą upoważniającą określony organ do dokonania aktu przymusu pod określonymi warunkami. Renzikowski konkluduje, że w tej sytuacji zarachowanie peryferyjne musi zostać przypisane państwu ${ }^{151}$. Ponadto zarachowanie centralne posiada jeszcze jedną funkcję na płaszczyźnie horyzontalnej, w ramach zarachowania peryferyjnego, mianowicie działania ludzkie łączy z osobą, w ten sposób stając się warunkiem zarachowania peryferyjnego. Osobie musi zostać zarachowane zachowanie niezgodne z prawem, aby mogło wejść w grę zarachowanie peryferyjne. Zarachowanie centralne w tym sensie służy ukonstytuowaniu osoby w znaczeniu prawnym i przypomina klasyczną postać zarachowania znaną z pism Pufendorfa i Kanta ${ }^{152}$.

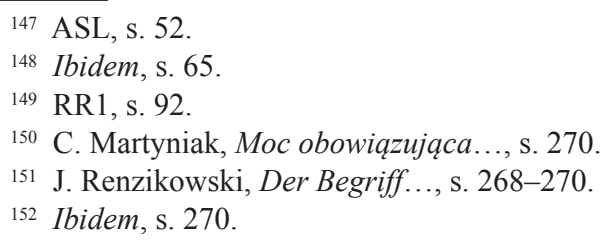


Zarachowanie centralne wyklucza jednak utożsamianie pojęcia woli, człowieka i osoby. Osoba fizyczna dla Kelsena to pewien kompleks norm regulujących zachowanie jednostki. Osoba prawna z kolei jest kompleksem norm dotyczących wielu ludzi, natomiast osoba w postaci państwa (Staatperson) to cały system prawa $^{153}$. Jeśli jakaś osoba ma prawo lub obowiązek, to oznacza, że określone zachowanie podpada pod stan faktyczny opisany w normie generalnej i to zachowanie jest jednocześnie warunkiem zastosowania aktu przymusu. Innymi słowy, aby można było określony stan faktyczny zarachować centralnie, musi być on wpierw zarachowany peryferyjnie. Oznacza to, że jedynie spełnienie obowiązku (albo wykonanie prawa) może zostać zarachowane centralnie. Bezprawność nie musi być tu w ogóle rozważana, ponieważ jest jedyne skutkiem ubocznym zarachowania peryferyjnego. Sprawca zostanie ukarany ze względu na jakiś delikt, gdyż stan faktyczny opisany w delikcie zawiera sankcję przeciw niemu ${ }^{154}$.

Alexy uzupełnia te rozważania, wskazując, że zarachowanie peryferyjne jest koniecznym składnikiem normy. Bez niego norma nie mogłaby istnieć, a co za tym idzie, nie mogłoby istnieć również zarachowanie centralne, które następuje, gdy zarachowanie peryferyjne zostanie już dokonane. Jeśli zatem dochodzi do zarachowania centralnego, to oznacza, że wcześniej musiało mieć miejsce zarachowanie peryferyjne. Natomiast nie jest do końca jasne, czy zarachowanie peryferyjne jest uzależnione od istnienia zarachowania centralnego. Aby to wyjaśnić, Alexy odwołuje się do rozróżnienia pomiędzy konkretnym i abstrakcyjnym zarachowaniem peryferyjnym. Konkretne dotyczy zastosowania normy w danym przypadku. Wówczas musi wchodzić w grę również podmiot, któremu norma prawna określone zachowanie zarachowuje. Wtedy występuje konieczność istnienia zarachowania centralnego. Z kolei abstrakcyjne zarachowanie peryferyjne istnieje w czystej postaci. Nie ma w nim podmiotu, któremu określoną czynność należałoby zarachować. W kontekście tych rozważań zarachowanie konkretne nazywa Alexy subiektywnym, natomiast abstrakcyjne obiektywnym ${ }^{155}$.

Moim zdaniem, te uwagi warto uzupełnić o stwierdzenie, że dotyczą one raczej tylko procesu stosowania prawa i to - odwołując się do Paulsonowskiej systematyki - w statycznym wymiarze. Zarachowanie peryferyjne, jeśli rozumieć je wąsko, jako łącznik między warunkiem a następstwem, jakim jest przymus, raczej nie będzie stanowiło punktu wyjścia w dynamicznym wymiarze, a w każdym razie nie bezpośrednio. W nim bowiem taką rolę pełni norma podstawowa. Inaczej jednak sytuacja będzie wyglądać, jeżeli zarachowanie peryferyjne ujmie się szerzej, jako łącznik między warunkiem a następstwem prawnym. Wówczas również i w aspekcie dynamicznym jest ono warunkiem koniecznym zarachowania centralnego. Jednak szeroka definicja zarachowania peryferyjnego rodzi dodatkowo problem tego rodzaju, że rola sankcji jako konstytutywnego elementu normy

${ }^{153}$ C. Heidemann, Der Begriff..., s. 22.

154 Ibidem.

${ }_{155}$ R. Alexy, Hans Kelsens..., s. 183-184, przyp. 27. 
trafia na dalszy plan. Zarachowanie łączące warunek z dowolnym następstwem przestaje być charakterystyczne jedynie dla prawa, wystarczy podać przykładową normę moralną: ,jeśli złożyłeś komuś bez świadków przyrzeczenie, to i tak powinieneś go dotrzymać". Jako relatywna kategoria a priori nie miałoby zatem sensu. Być może jednak najlepsze rozwiązanie zaproponował Heidemann wskazując, tak jak poprzednicy, że zarachowanie komuś zachowania, oznacza, że to zachowanie znajduje się wewnątrz części systemu prawa i w ten sposób jest ono jednością tego systemu. Stwierdzenie, że ktoś ma obowiązek lub uprawnienie oznacza, że ich zaprzeczenie jest opisane w stanie faktycznym normy generalnej, jako warunek zastosowania aktu przymusu. Zatem najpierw ów stan faktyczny zarachowany jest peryferyjnie, by następnie został zarachowany centralnie osobie. Heidemann jednak uzupełnia rozważania o stwierdzenie, że w przypadku państwa zarachowywane są nie prawa i obowiązki, lecz akty, na mocy których normy są ustanawiane i stosowane ${ }^{156}$. Przy takiej interpretacji można jednak wyodrębnić dwie sytuacje: zarachowanie osobie innej niż państwo, gdzie zarachowanie peryferyjne jest warunkiem zarachowania centralnego oraz zarachowanie centralne dotyczące państwa, gdzie zarachowanie peryferyjne jest „ostatnim taktem dynamicznej struktury prawa” i gdzie, jak się wydaje, warunek, który zarachowanie peryferyjne łączy z następstwem, to łańcuch kolejnych zarachowań centralnych.

Moim zdaniem, twierdzenie, że zarachowanie peryferyjne jest zawsze (zarówno w statycznym, jak i dynamicznym wymiarze) warunkiem zarachowania centralnego jest dość ryzykowne i nie do końca jasne. Znacznie klarowniejszym wydaje mi się postrzeganie zarachowania peryferyjnego jako warunku zarachowania centralnego w horyzontalnym aspekcie i jako ,ostatniego taktu tworzenia prawa" przy powiązaniach wertykalnych.

Podsumowując rozważania dotyczące zarachowania centralnego, warto przytoczyć spostrzeżenie Heidemanna, że nie do końca wiadomo, jaką funkcję ono pełni. Normy wtórne, do których się odnosi, są jedynie „refleksem” norm pierwotnych. Konstytutywne dla nauki prawa jest zatem zarachowanie peryferyjne. Heidemann wskazuje, że o ile w pierwszej fazie zarachowanie centralne spełniało dwie funkcje, czyli było konstytutywną częścią porządku prawnego oraz gwarantowało jedność systemu prawnego, o tyle w fazie klasycznej pierwsza funkcja pozostała przy zarachowaniu centralnym, a druga została przejęta przez dynamiczną strukturę prawa i normę podstawową. Tym samym zarachowanie centralne stało się niepotrzebnym reliktem ${ }^{157}$.

Z przedstawionej analizy wynika ścisła zależność między zarachowaniem peryferyjnym, centralnym i dynamiczną strukturą prawa. Widoczna jest również przydatność pojęcia pełnej normy prawnej, które pozwala na wyjaśnienie relacji zachodzących między zarachowaniem peryferyjnym a centralnym. Przy okazji

\footnotetext{
156 C. Heidemann, Der Begriff..., s. 22-23.

157 Ibidem, s. 24.
} 
ta zależność pokazuje, jak niekompletna była czysta teoria prawa w pierwszej fazie. Jednak uczynienie teorii bardziej spójną nie ustrzegło Kelsena przed wikłaniem się w nowe problemy. Można na przykład postawić pytanie, jak ma się końcowy punkt zarachowania centralnego do „ostatniego taktu” czy zastosowania przymusu w zarachowaniu peryferyjnym i dynamiczną strukturą prawa. $\mathrm{O}$ ile możliwe jest $\mathrm{w}$ miarę spójne połączenie woli państwa $\mathrm{z}$ zastosowaniem przymusu oraz połączenie hierarchicznej struktury prawa $\mathrm{z}$ zarachowaniem centralnym, o tyle próba syntezy spojrzenia wertykalnego na prawo $z$ horyzontalnym wydaje się być skazana na porażkę. Kelsen nie udziela odpowiedzi na przykład na pytanie, co z łańcuchem norm, na końcu którego nie ma aktu przymusu? Co z tymi wszystkimi zobowiązaniami prawnymi, które są należycie wykonywane? Czy w takim wypadku po prostu nie ma zarachowania peryferyjnego? Wydaje się zatem, że w kelsenowskiej wizji prawa widoczne jest tutaj pęknięcie i tak naprawdę oferowane są dwie wizje prawa: pierwsza dotyczy spojrzenia horyzontalnego, druga wertykalnego. Jest to niewątpliwie wada zaproponowanej przeze mnie interpretacji.

\subsection{Podsumowanie}

Faza klasyczna niewątpliwie pozostawiła wyraźny ślad w doktrynie. Włączenie w czystą teorię prawa wątków neokantowskich większość oceniała pozytywne, jako postęp wobec pierwszej fazy. Jednak było to również przedmiotem krytyki, na przykład dokonanej przez Landego, który uznał wyższość teorii przedstawionej w HP:

Kelsen w swych pismach nowszych przejął się, ze szkodą dla wyników naukowych, dążeniami o wysokim polocie „filozoficznym”, które się wyrażają we wtłaczaniu rozumowań w obce im schematy „,idealizmu transcendentalnego" i w pretensjonalnej terminologii, zapożyczonej od Kanta [...]. Wśród skutków tego zwrotu wybija się na pierwszy plan pod względem szkodliwości typowe dla Kanta i opłacone już tyloma błąkaniami przez jego epigonów pomieszanie zdań logiki i epistemologii, zawierających ocenę poznania, ze zdaniami nauki, zawierającymi samo poznanie przez tamte ocenianie. Stąd jego „,czysta teoria prawa” ma raz za zadanie osiągnięcie ,jedności poznania $\mathrm{w}$ dziedzinie prawa na podobieństwo nauk przyrodniczych $\mathrm{w}$ dziedzinie natury. gdzie indziej ma być teorią obowiązywania norm prawnych niezależnie od ich treści i jako taka częścią „ogólnej teorii normatywnej”; raz ma być samą nauką normatywną, to znów - i to właśnie jako epistemologia! - nauką teoretyczną przeciwstawianą stanowisku „etyczno-politycznemu”. Górnolotne te koncepcje nie wymagają krytyki, gdyż same się zbijają nawzajem ${ }^{158}$.

Wydaje się, że przedstawiona krytyka jest zbyt surowa. Tym, co Lande nazywa „pretensjonalnym”, większość nazwałaby (nie bez przyczyny) „wyrafinowanym”. Owszem, Kelsen, dokonując recepcji neokantyzmu na użytek własnej

158 J. Lande, Studia z filozofii prawa, PWN, Warszawa 1959, s. 289-290. 
teorii, przy okazji przejął jej wady, ale osiągnął istotny cel. Dzięki filozoficznemu uzasadnieniu jego teoria przestała sprawiać wrażenie „zawieszonej w powietrzu”, niekompletnej i jak to ujął Lande, ograniczonej wyłącznie do „walki z synkretyzmem metod w nauce prawa"159.

Warto zaznaczyć, że odniesienie do neokantyzmu bardzo ostro krytykuje Gerhard Luf. Wskazuje, że Kelsen, po pierwsze, nie rozumie praktycznej filozofii Kanta, mającej oparcie w wolności od tradycyjnej filozofii prawa natury. Praktyczna filozofia rozumu, jak wskazuje Luf, opiera się na praktycznym pytaniu, „,co powinienem czynić" skierowanym na cele woli i działania. Pytanie to jest transcendentalne, odnosi się bowiem do bezwarunkowej moralności - koniecznej w świecie istot kierujących się jedynie nakazami rozumu. To pytanie - według Lufa - również można odnieść do płaszczyzny prawa, w szczególności normatywnych zasad w działaniu i warunków dla możliwości tworzenia przez racjonalne jednostki świata społecznego w zgodności z bezwarunkowymi uniwersalnymi zasadami. Chodziłoby tu zatem o aspekt treściowy norm, a nie formalny. Owo pytanie z punktu widzenia metodologii ma ten sam status co analogicznie na gruncie rozumu teoretycznego. Co więcej, o ile z teoretycznej perspektywy świat noumenów jest niedostępny, o tyle z praktycznej musi zostać założony, aby moralność odpowiadała rozumowi, zaś działania ludzkie muszą być wolne, aby istniała możliwość użycia rozumu w ich przeprowadzeniu. Stąd też wolność jest centralnym pojęciem filozofii praktycznej, będąc jednocześnie tym, co zapobiega uwikłaniu prawa w koncepcje prawno-naturalne ${ }^{160}$. Wydaje się, że Luf ma rację, zarzucając Kelsenowi brak zrozumienia dla filozofii praktycznej Kanta. Jednak, czy można Kelsenowi zarzucić, że nie wykorzystał tej kantowskiej koncepcji? Moim zdaniem, ewentualnie byłoby to możliwe w odniesieniu do twierdzenia Kelsena, że teoria prawa musi abstrahować od treści, koncentrując się jedynie na formie, przy roszczeniu czystej teorii prawa do wyłączności. I to pod warunkiem, że praktyczna filozofia Kanta rzeczywiście pozwala na ustalenie treści norm w sposób, który zapobiegałby wikłaniu się w ideologię.

Takie podejście rodzi kolejne pytanie, o to, czy Kelsen, w końcu pisząc o prawie, nie popełnił błędu, przesuwając swoje rozważania z rozumu praktycznego do teoretycznego? Należy jednak pamiętać o założeniach, które Kelsen stworzył dla swojej teorii. W końcu poszukiwał on odpowiedzi na pytanie, jak nauka prawa jest możliwa i za neokantystami stworzył teorię analogiczną wobec teorii poznania Kanta. W tym miejscu można byłoby się zapytać, czy nauka prawa nie byłaby możliwa w oparciu założenia rozumu praktycznego. Myślę, że Kelsen mógłby odpowiedzieć na to, że obranie, jako punktu wyjścia koncepcji wolności, nawet w kantowskim rozumieniu jest jednak założeniem metafizycznym. Dzisiejsza nauka, na przykład, kognitywistyka, wskazuje raczej, że jesteśmy zdeterminowani przez przyrodę bardziej, niż sądziliśmy, zatem wolność rozumu praktycznego

\footnotetext{
159 Ibidem, s. 140.

160 G. Luf, On Transcendental..., s. 227-230.
} 
może zostać zakwestionowana. Oczywiście Kant twierdzi, że właśnie dlatego, że nie można założyć, że w życiu kierujemy się zawsze nakazami imperatywu kategorycznego, musi istnieć prawo. Właśnie po to, by w ramach porządku prawnego zagwarantować nam wolność. Jednakże, widoczny jest tu postulat, co do treści prawa, jakie prawo być powinno. Kelsen natomiast chciał opisać prawo takie, jakim ono jest. Żeby jego teoria spełniła warunki naukowości, musiał wyrugować treść, tak by jego opis pasował do każdego prawa, bez względu na czas i miejsce obowiązywania. Zaangażowanie filozofii praktycznej Kanta mogłoby się dla Kelsena wiązać $\mathrm{z}$ rezygnacją z wielu podstawowych założeń jego teorii, z tezą o dualizmie bytu i powinności włącznie.

Przy każdym z rozważanych podejść coś zyskujemy i coś tracimy. Formalizm Kelsena zapobiega zarzutom o lokalności jego teorii ze względu na treść oraz zarzutom, że wpierw musimy się zgodzić na bardzo silne założenia etyki kantowskiej oraz przejścia od opisu prawa do postulatów, jakie prawo być powinno. Z kolei teoria Kanta daje szansę na stworzenie ogólnych zasad, również dotyczących treści samego prawa. Myślę, że kelsenowskie podejście nie jest złe, pod warunkiem, że zrezygnujemy z roszczenia do wyłączności jego teorii jako jedynej prawomocnie opisującej prawo. Moim zdaniem, obie teorie traktują o nieco innych aspektach prawa.

Następnie, Luf, słusznie moim zdaniem wskazuje, że Kelsen, opierając się na Krytyce czystego rozumu, sprowadza prawo do czegoś analogicznego do materialnych przedmiotów, jednocześnie umiejscawiając je w sferze powinności. W rezultacie to wszystko doprowadza Kelsena do metafizyki, od której próbował się wszelkimi sposobami odciąć. Dalej Luf stwierdza, że wysiłki Kelsena, by ufundować naukową teorię prawa, poszukującą jego apriorycznych struktur, muszą zakończyć się niepowodzeniem, taka bowiem teoria nie jest w stanie tych struktur przedstawić. Zamiast tego, bazuje na empirycznym materiale prawnym uporządkowanym na podstawie przyjętej metodologii i następnie poddanego wysokiemu stopniowi formalizacji. Taki zabieg jednak może jedynie sprowadzić teorię do bycia abstrakcyjnym schematem prawa w swym wymiarze empirycznym. W ten sposób relatywna kategoria a priori nie jest koncepcją mającą swoje ugruntowanie w transcendentalizmie, a jedynie funkcjonuje jako „hipotetyczny ogólny koncept otrzymany za pomocą abstrakcji”"161. Moim zdaniem, i tu Luf się nie myli, jednak warto zauważyć, że czysta teoria prawa pozbawiona tak silnego transcendentalnego elementu, będąca jedynie abstrakcyjnym schematem prawa w swym wymiarze empirycznym wciąż wydaje się być teorią atrakcyjną i w dostatecznym stopniu spójną.

Znacznie bardziej wyważoną ocenę formułuje Wróblewski, zwracając uwagę, że silne ukierunkowanie na tematykę epistemologiczną doprowadziło do marginalizacji problemów ontologicznych ${ }^{162}$. Wróblewski również słusznie zauważa, że:

161 Ibidem, s. 227-232.

162 J. Wróblewski, Egologiczna teoria prawa przeciw czystej teorii prawa, „Państwo i Prawo” 1959, nr 8-9, s. 306. 
Kelsen szuka ugruntowania normatywizmu w filozofii w dużej mierze nie po to, by szereg spraw rozstrzygnąć, ale po to wskazać, że one w żaden sposób rozstrzygnąc się nie dadzą - po to, by wskazać, że ostatecznie napotyka się z konieczności na sporne założenia, których wybór jest naukowo niezdeterminowany. Kelsen, opierając się na zmodyfikowanych przez rozmaite dodatki koncepcjach kantowskich, nie chce programowo przesądzać wielu kwestii, nie stara się zająć jakiegoś zdecydowanego stanowiska w zasadniczych dla niego a przeciwstawnych sobie poglądach filozoficznych [...] Kelsen, chowając się w opiekuńczy cień agnostycyzmu kantowskiego, relatywizując go aż do sceptycyzmu, zadowala się tylko wskazaniem, czy raczej próbą wskazania, jak rozstrzygnięcie zasadniczych kwestii filozoficznych wyznacza w swej konsekwencji rozstrzygnięcie, jakie daje teoria prawa ${ }^{163}$.

Samo zarachowanie peryferyjne okazało się jednak konstrukcją udaną i jak już wcześniej zostało to wykazane, przydatną. Wprawdzie w roli relatywnej kategorii a priori nie zdało egzaminu, ale wynika to raczej z wadliwości samego argumentu. Z kolei, o ile powiązania z zarachowaniem centralnym na płaszczyźnie horyzontalnej można uznać tworzące w miarę spójny obraz, o tyle w ujęciu wertykalnym widać pewne braki, które być może wynikają ze wskazanego przez Wróblewskiego nazbyt silnego skupienia na wątkach epistemologicznych. Wydaje się, że Kelsen zdał sobie z tego sprawę, ponieważ w kolejnej fazie wątki te stopniowo zanikają, co zostanie dalej opisane.

163 J. Wróblewski, Krytyka normatywistyczej..., s. 29-30. 


\section{Rozdział VI Zarachowanie w fazie realistycznej}

\subsection{Charakterystyka fazy realistycznej}

Trzecia faza, którą Heidemann nazwał realistyczną, charakteryzuje się osłabieniem tendencji neokantowskich. Kelsen dodaje nowe elementy do swojej teorii czerpiące źródło z empiryzmu i sceptycyzmu. Pojawiają się również narzędzia analityczne. W doktrynie za punkt zwrotny zwiastujący zmianę koncepcji i osłabienie wątków neokantowskich uważa się najpierw pracę z dziedziny etnologii Vergeltung und Kausalität ${ }^{1}$, następnie, w zakresie teorii prawa: General Theory of Law and State"2 (GTLS) wydaną w 1945 r. Jak wskazuje Hartney, celem tej publikacji jest przeformułowanie teorii, tak by dotarła do anglojęzycznych czytelników. Częściowo jest ona thumaczeniem Ogólnej nauki o państwie z 1925 r., ale zawiera również wątki nowe, w szczególności odnoszące się do teorii znanych po drugiej stronie Atlantyku, na przykład do teorii Johna Austina ${ }^{3}$. To właśnie w niej pojawiło się rozróżnienie na zdanie prawne i normę prawną, echa sceptycyzmu oraz elementy empiryczne. Jak wyjaśnia Paulson, te ostatnie zostały wprzęgnięte w czystą teorię prawa za sprawą fascynacji Kelsena Humem. Kelsen stopniowo rezygnuje z neokantowskiego rozumienia przyczynowości jako kategorii a priori, na rzecz Humowskiego, głoszącego, że przyczynowość to jedynie myślowe przyzwyczajenie wywołane przez obserwację pewnych sekwencji ${ }^{4}$. Wyrazem tego poglądu była wspomniana Vergeltung und Kausalität, w której Kelsen dokonuje gruntownej rozprawy z pojęciem przyczynowości, dochodząc do wniosku, że prymitywne społeczności nadawały znaczenie zjawiskom naturalnym nie na mocy zasady przyczynowości, ale na mocy szczególnej odmiany zarachowania, którą jest zadośćuczynienie.

Sceptycyzm z kolei przejawiał się w odniesieniu do twierdzenia, że treść norm niższego rzędu jest determinowana przez treść norm wyższego rzędu. Kelsen

${ }^{1}$ H. Kelsen, Vergeltung und Kausalität, Herman Böhlaus Nachf., Wien, Köln, Graz 1982.

${ }^{2}$ H. Kelsen, General Theory of Law and State, The Law Book Exchange Ltd. Union, New Jersey 1999.

${ }_{3}^{3}$ M. Hartney, Introduction: The Final Form of the Pure Theory of Law, [w:] H. Kelsen, General Theory of Norms, trans. M. Hartney, Clarendon Press, Oxford 1991, s. XXVIII.

${ }^{4}$ S. Paulson, Toward a Periodisation of the Pure Theory of Law, [w:] L. Gianformaggio (ed.), Hans Kelsen's Legal Theory a Diachotonic Point of View, G. Giappichelli Editore, 1990, s. 40-41. 
zauważył, że organy tworzące prawo nie są w stanie do końca przewidzieć, w jaki sposób będzie ono stosowane, a ostatnie słowo, czyli wykładnia prawa, należy do organów prawo stosujących (sędziów i urzędników). Ten wniosek powoduje przesunięcie zainteresowania $\mathrm{z}$ norm generalnych na normy indywidualne, co w końcu doprowadzi Kelsena do ostatniej fazy, to jest językowo-analitycznej5.

$\mathrm{Na}$ gruncie epistemologii zaszły jeszcze bardziej radykalne zmiany, choć na pierwszy rzut oka niewidoczne. Heidemann wskazuje, że faza realistyczna charakteryzuje się naiwnym realizmem, polegającym na redukcji poznania prawnego do poznania o charakterze empirycznym. U podstaw teorii Kelsena z tamtego okresu znajdują się dwa twierdzenia ${ }^{6}$ : po pierwsze, nauka jest równoznaczna z poznaniem rozumianym jako opis danych obiektów, co prowadzi do podziału na normy prawne i zdania prawne; po drugie, obiektywność jest równoznaczna z możliwością empirycznej weryfikacji, w rezultacie czego obiekt poznania nie jest już konstytuowany przez kategorie ${ }^{7}$. Teza Heidemanna budzi jednak pewne wątpliwości, ponieważ Kelsen jednocześnie wskazuje na normę podstawową jako warunek pozwalający na rozpoznanie obiektywnego charakteru normy prawnej i następnie stwierdza, że jeśli odmówić normie jej charakteru nadanego przez zarachowanie, to wszelkie wypowiedzi prawne utraciłyby swój sens ${ }^{8}$. Czy Heidemann ma rację, częściowo zostanie rozstrzygnięte podczas analizy zarachowania jako relatywnej kategorii a priori. Jeśli jednak przytoczone przez Heidemanna tezy są słuszne, to ich konsekwencją są dwie kolejne, mające ugruntować obiektywność norm?.

Po pierwsze, nie ma obiektów idealnych w odniesieniu do świata nauki. Oznacza to, że nauki nieempiryczne o obiektach idealnych mają charakter metafizyczny, co już na starcie dyskredytuje je jako nauki. To powoduje konieczność rezygnacji z wszelkiej terminologii, która miałaby konotacje z idealistyczną ontologią. W rezultacie znika definicja obowiązywania jako „idealnej” egzystencji normy prawnej oraz wyjaśnienie dualizmu bytu i powinności poprzez odwołanie się do podziału na świat natury i świat ducha ${ }^{10}$.

Po drugie, według Kelsena, normy mogą być tylko wtedy obiektem nauki, gdy są sensem faktów empirycznych ${ }^{11}$. Jak wskazuje Heidemann, ta teza jest Kelsenowi niezbędna, aby pogodzić przytoczoną koncepcję nauki z dualizmem bytu i powinności ${ }^{12}$. Podejście realistyczne ograniczyło zatem wątki epistemologiczne

\footnotetext{
5 Ibidem, s. 42.

${ }^{6}$ C. Heidemann, Die Norm als Tatsache. Zur Normentheorie Hans Kelsen, Nomos Verlagsgesellschaft, Baden-Baden 1997, s. 106.

7 Ibidem, s. 108.

8 RR2, s. 110.

9 C. Heidemann, Die Norm als..., s. 108.

${ }^{10}$ Ibidem, s. 109.

${ }^{11}$ Ibidem.

${ }^{12}$ Ibidem.
} 
wraz z neokantowską zasadą, że metoda poznania konstytuuje przedmiot poznania. Od tej pory, to prawodawca, a nie badacz tworzy przedmiot poznania, którym jest norma prawna ${ }^{13}$. Z Heidemannem zgadza się Fritzsche, twierdząc, że teoria Kelsena z tego okresu wyraźnie zalicza się do koncepcji realistycznych, a Kelsen porzuca kantowską doktrynę: prawo tworzone jest przez ludzi, zaś jego obowiązywanie nie jest uzależnione od prawa boskiego czy też prawa natury. Kelsen nie opisuje prawa idealnego, tylko prawo istniejące, realne ${ }^{14}$.

Heidemann wskazuje, że zmiana założeń doprowadziła do następujących konsekwencji ${ }^{15}$. (1) Status normy prawnej jako obiektu danego poznaniu stał się niejasny. Wprawdzie Kelsen definiuje normę jako sens aktu intencjonalnego skierowanego na ludzkie zachowanie, jednak owa definicja niewiele tłumaczy; (2) kategoria powinności traci swoją funkcję formy poznania. Dualizm bytu i powinności sprowadza się wyłącznie do tezy, że nie da się ze zdania powinnościowego wyprowadzić zdania o bycie; (3) możliwość zastosowania logiki do norm prawnych zaczyna być problematyczna. Wprawdzie Kelsen utrzymuje, że z punktu widzenia logiki normy oddziałują pośrednio między sobą dzięki zdaniom prawnym, lecz zdaniem Heidemanna to rozwiązanie jest mało przekonujące; (4) niejasny staje się status normy podstawowej, raz przyporządkowanej płaszczyźnie obiektów, innym razem będąc aktem myślowym niezorientowanym na ludzkie zachowanie. Jest ona również warunkiem poznania; (5) pojawiają się wątpliwości odnośnie do statusu nauki prawa. Nie jest jasne, jaki ma teraz charakter: konstytutywny czy opisowy.

W systematyce swojej teorii Kelsen wprowadza wyraźne rozróżnienie na statyczne i dynamiczne ujęcie prawa ${ }^{16}$. Prawo w ujęciu statycznym jest postrzegane jako „prawo w spoczynku” ${ }^{17}$. Są to obowiązujące normy wyłącznie o charakterze generalnym. Prawo w ujęciu dynamicznym kładzie nacisk na cały system prawa, na różnych szczeblach jego hierarchicznej struktury. Ma wielowymiarowy charakter, a przedmiotem badań jest relacja norm indywidualnych i generalnych. Choć Kelsen twierdzi, że w tym zakresie, w którym chodzi o konstruowanie zawartości norm prawnych, aspekt dynamiczny jest ważny dla poznania prawne$\mathrm{go}^{18}$, to Heidemann wskazuje, że nie jest on i nie może być elementem czystej teorii prawa, zaś te dwa ujęcia nie do końca ze sobą współgrają ${ }^{19}$.

Te wszystkie zmiany spowodowały, że czysta teoria prawa Kelsena zaczęła nabierać innego charakteru. Dla prowadzonych przeze mnie rozważań

13 Ibidem, s. 112.

${ }^{14}$ T. Fritzsche, Die ReineRechtslehre im Lichte des Kritischen Rationalismus, Schriftenreihe des Hans Kelsen-Instituts, Wien 2002, s. 14.

15 C. Heidemann, Noch einmal: Stanley L. Paulson und Kelsens urteilstheoretischer Normbegriff, „Archiv für Rechts-und Sozialphilosophie“ 2007, Bd. 93, s. 353.

16 RR2, s. 72-73.

17 Ibidem.

${ }_{18}$ Ibidem.

19 C. Heidemann, Die Norm als..., s. 127-129. 
najważniejsze jest pytanie o wpływ, jaki miały te zmiany na zarachowanie. Jednak, by na nie odpowiedzieć, należy najpierw zbadać modyfikacje w rozumieniu dualizmu bytu i powinności oraz pojęcia normy prawnej.

\subsection{Dualizm bytu i powinności}

Jak już wspomniano, Kelsen, odrzucając idealizm, jest jednocześnie zmuszony do rewizji swoich poglądów dotyczących dualizmu bytu i powinności. O ile byt jest definiowany jako fakty czy też natura, o tyle z definicją powinności Kelsen nadal ma problem. Wciąż utrzymuje, że powinność jest niedefiniowalna. Sam dualizm nie mogąc być uzasadniony przez odwołanie się do swoistej ontologii, która pociągałaby za sobą wątki idealistyczne, musi szukać swych postaw gdzie indziej. Jak wskazuje Heidemann, początkowo Kelsen usiłował wyjaśnić powinność jako wolę obiektywną, jednak zrezygnował z tego dość szybko, zastępując je jeszcze mniej jasnym sformułowaniem, że powinność jest sensem aktu intencjonalnego skierowanego na zachowanie ${ }^{20}$. Poza problemami terminologicznymi odrzucenie wątków idealistycznych zrodziło kolejną trudność - uzasadnienia owego dualizmu. Ze wszystkich płaszczyzn pozostała tylko jedna - płaszczyzna logiczna wraz ze słynnym twierdzeniem Hume'a. To musiało Kelsenowi wystarczyć za uzasadnienie ${ }^{21}$. Obok redukcji tego wątku pojawiły się również elementy nowe. Podstawową zmianą mającą doniosłe konsekwencje dla zarachowania jest stwierdzenie, że powinność sensu largo zawiera w sobie również inne modalności: nakaz, zakaz, dozwolenie oraz upoważnienie ${ }^{22}$. Z kolei w przypadku związków między bytem i powinnością Heidemann wyróżnia cztery sytuacje, w których doszło do zmian w stosunku do drugiej fazy.

Po pierwsze, powinność w postaci normy jest obiektem nauki, tylko jako sens empirycznych faktów. Owe fakty najpierw były rozumiane przez Kelsena jako ludzkie zachowania, potem akt intencjonalny skierowany na zachowanie innego podmiotu, którym jest akt woli23.

Po drugie, Kelsen stawia większy nacisk na pojęcie skuteczności prawa jako warunku obowiązywania. Dotyczy ono nie tylko całości porządku prawnego, ale również każdej pojedynczej normy prawnejej.

Po trzecie, Kelsen wraca do koncepcji z pierwszej fazy, według której powinność jest skierowana na byt ${ }^{25}$.

\footnotetext{
20 Ibidem, s. 114.

${ }^{21}$ Ibidem.

${ }^{22}$ RR2, s. 4, 81.

${ }^{23}$ C. Heidemann, Die Norm als..., s. 120.

${ }^{24}$ Ibidem, s. 121.

${ }^{25}$ Ibidem.
} 
Po czwarte, Kelsen stawia tezę, że pomiędzy sferą bytu i sferą powinności istnieje „coś”: powinne lub istniejące zachowanie, które raz jest, a raz powinno być. To „coś”, Kelsen nazywa zawartością bytu lub powinności. Stwierdza też, że dualizm bytu i powinności nie oznacza braku powiązań pomiędzy nimi. Byt może odpowiadać powinności, czyli „coś może być takie, jakie być powinno”, a powinność skierowana jest na byt ${ }^{26}$. Temu elementowi zostaje nadana nazwa substratu modalnie indyferentnego. To „coś”, co raz jest bytem, a innym razem powinnością, ma zarówno cechę , bycia” bytem, jak i „bycia” powinnością. Z drugiej strony, zauważa Kelsen, nie jest tak, że byt i powinność są odpowiednikami, Stan faktyczny może korespondować z opisem tego stanu zawartego w normie, ale nie musi. Zdanie dotyczące powinnego zachowania może albo jedynie stwierdzać, że coś być powinno, albo też jednocześnie być zgodne ze stanem faktycznym $^{27}$. Jak wskazuje Heidemann, nie jest jasne, jaka jest relacja tego pojęcia do pojęcia normy ${ }^{28}$. Zagadnienie substratu modalnie indyferentnego i jego relacja do zarachowania zostaną omówione dopiero w następnym rozdziale.

Rozróżnienie świata obiektów i płaszczyzny poznawczej w realistycznym ujęciu zaowocowało kilkoma podziałami. Pierwszy z nich to podział na powinność w znaczeniu deskryptywnym i preskryptywnym. Powinność w sensie preskryptywnym znajduje się $\mathrm{w}$ normie prawnej, natomiast $\mathrm{w}$ znaczeniu opisowym w zdaniach prawnych opisujących owe normy ${ }^{29}$.

Innym podziałem jest podział na powinność samodzielną i niesamodzielną. Powinność samodzielna to ta, której nazwa bierze się stąd, że norma, do której się odnosi, nie jest uzależniona od istnienia innej normy. Powinność samodzielna jest związana z normami pierwotnymi; natomiast powinność niesamodzielna jest związana z normami wtórnymi ${ }^{30}$. Jednocześnie, jak wskazuje Heidemann, Kelsen utożsamia samodzielną powinność z zarachowaniem peryferyjnym oraz z umocowaniem. Nakaz i zakaz powiązane z powinnością niesamodzielną są jedynie pewnym refleksem powinności samodzielnej. Nakaz wchodzi w grę wtedy, gdy zachowanie przeciwne wobec nakazanego obarczone jest sankcją, a zakaz, gdy zachowanie opisane w zakazie obarczone jest sankcją ${ }^{31}$.

Kelsen odróżnia również subiektywne znaczenie powinności od obiektywnego. Powinność jest subiektywnym sensem każdego ludzkiego aktu woli o odróżnieniu od sensu obiektywnego, gdzie tylko niektóre akty woli mają taki charakter. Tylko obiektywna powinność znajduje swoje odbicie w normie ${ }^{32}$. Powinność w sensie subiektywnym to na przykład polecenie bandyty w banku, by kasjer

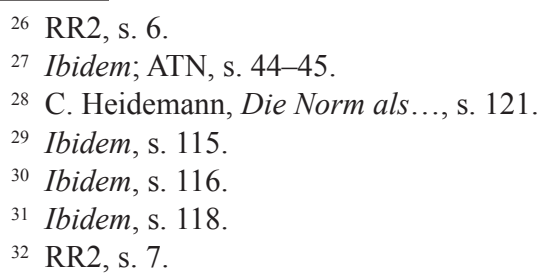


otworzył skarbiec. Powinność w znaczeniu obiektywnym jest ustanawiana przez każdą obowiązującą normę prawną. Taka norma nie traci swojego obowiązywania, gdy znika akt woli, czerpie je bowiem z normy hierarchicznie wyższej. Kelsen zaznacza, że norma podstawowa jest tym, co subiektywnemu aktowi prawodawczemu nadaje obiektywny sens ${ }^{33}$, i dodaje, że norma nie musi być jedynie sensem aktu woli, może również zostać pomyślana bez woli tak, by zaistniała. Wówczas jednak nie jest normą prawa pozytywnego, tylko normą istniejącą w myśli, a więc o charakterze subiektywnym ${ }^{34}$. Reasumując, dana norma jest normą prawną, jeżeli została pomyślana jako akt woli przez odpowiedni podmiot mający kompetencje jej ustanowienia i została przez ten podmiot ustanowiona.

\subsection{Norma prawna i zdanie prawne}

Kelsen w trzeciej fazie wprowadza na pierwszy plan nieco inną definicję normy prawnej. Twierdzi, że norma jest sensem aktu, poprzez który określone zachowanie jest nakazane lub dozwolone, dodając, że poprzez sens rozumie to, że „coś powinno być lub się wydarzyć, w szczególności, że człowiek powinien się w określony sposób zachować" ${ }^{35}$. Doktryna jest zgodna: ta definicja rodzi wiele wątpliwości. Hartney zwraca uwagę, że nie można postawić znaku równości między „znaczeniem aktu” w RR1 i RR2. W RR1 znaczeniem było coś, co zostało do tego aktu dodane. Akt zabicia kogoś w świecie powinności stawał się zabójstwem albo egzekucją skazanego na śmierć36. Warto zatem najpierw zastanowić się, co Kelsen miał na myśli, pisząc o sensie aktu woli. Według tego, co już zostało przytoczone wcześniej, mamy do czynienia $\mathrm{z}$ aktem woli, że określona osoba powinna zachować się w odpowiedni sposób. Wydaje się, że pierwszym skojarzeniem, które się nasuwa przy relacji norma - akt woli, jest stwierdzenie, że norma jest formą, którą akt woli przybiera. Jednak podążając tym tropem, trudno byłoby uzasadnić kelsenowskie twierdzenie. Kelsen zauważa, że sens aktu woli może być oddany jedynie poprzez zdanie o charakterze powinnościowym (którym jest norma). Jednak, czy z faktu, iż tylko norma może oddać sens takiego aktu woli, wynika, że ona sama jest jego sensem? Raczej ten trop również prowadzi do twierdzenia, że norma jest formą, którą powinien przybrać omawiany akt woli. Dalej Kelsen zauważa, że tak zdefiniowana norma musi być czym innym od aktu woli, którego jest sensem. Różnica polega na zaliczeniu normy do sfery powinności, podczas gdy aktu woli do sfery bytu ${ }^{37}$. W rezultacie akt woli jest „lustrzanym odbiciem” normy w sferze bytu.

\footnotetext{
33 Ibidem, s. 7-8.

34 Ibidem, s. 9.

${ }^{35}$ Ibidem, s. 4-5.

${ }^{36}$ M. Hartney, Introduction..., s. XXXII.

37 RR2, s. 5; por. HP I, t. 1, s. 86.
} 
Kelsen obrazuje to twierdzenie następującym zdaniem: „ktoś chce, aby kto inny miał powinność zachowania w określony sposób" ${ }^{38}$. Kelsen zwraca uwagę, że pierwszy człon zdania odnosi się do sfery bytu, drugi do sfery powinności, co jest dowodem na niemożliwość redukcji normy prawnej do aktu woli będącego jej źródłem. Pojęcie powinnego zachowania jest dwuznaczne. Może zarówno dotyczyć zachowania, które zarazem jest przedmiotem powinności i faktycznie ma miejsce, jak i zachowania wyłącznie opisanego jako powinne ${ }^{39}$. To stwierdzenie wydaje się bardziej zrozumiałe. Akt woli jest pewnym faktem, który za pomocą przedstawionego powyżej schematu przekształca się w powinność, czyli w normę. Być może Kelsen chciał powiedzieć, że w rzeczywistości prawnej, w sferze powinności odpowiednikiem aktu woli jest norma prawna i z punktu widzenia tej rzeczywistości jest ona właśnie sensem aktu woli. Gdyby akt woli w rzeczywistości prawnej nie został ujęty w normę prawną, nie miałby on w tej sferze najmniejszego sensu, lecz byłby jedynie pustym zdaniem, które równie dobrze mogłoby nie istnieć. Można zauważyć, że jeśli cała konstrukcja opiera się na akcie woli dotyczącym zachowania innej osoby, to $\mathrm{w}$ istocie norma prawna jest tym, co konkretyzuje sposób zachowania, wypełnia treścią całą konstrukcję, zatem jest sensem tego aktu woli.

Według Kelsena stwierdzenie: „określona norma została ustanowiona” oznacza, że norma jest „sensem, lub znaczeniem działania lub działań, które zostały podjęte w procesie stanowienia prawa" ${ }^{40}$. W rezultacie norma jest nie tylko sensem aktu woli, ale również wszelkich działań zmierzających do jej ustanowienia. To stwierdzenie raczej nie budzi kontrowersji. Norma prawa jako cel działań zmierzających do jej ustanowienia nadaje jednocześnie tym działaniom sens. Tego typu akty mogą być wyrażane w różny sposób: poprzez gesty, symbole, słowa. W tym ostatnim przypadku norma może przybrać różna postać, na przykład zdania oznajmującego. Nie znaczy to, że staje się przez to opisem rzeczywistości, ponieważ ważny jest sens zdania (powinność), a nie jego forma ${ }^{41}$. Warto tutaj nawiązać do koncepcji normy prawnej Zygmunta Ziembińskiego, który również zwraca na to uwagę, wskazując, że odróżnienie norm od innych wypowiedzi opiera się na kryteriach semiotycznych, jaki sens przypisuje się danej wypowiedzi (przyznając jednocześnie, że najpopularniejszą postacią normy jest jej postać powinnościowa) ${ }^{42}$. Wyraźnie widać, że Kelsen inaczej kładzie tu nacisk, ponieważ u niego decydująca jest powinność. Stanowisko to ulegnie pewnej modyfikacji w ostatniej fazie, w której znaczenia nabiorą wątki językowe, jednak, moim zdaniem, dla Kelsena nawet wtedy podstawowym kryterium jest powinność.

38 Ibidem.

39 Ibidem, s. 6.

40 Ibidem, s. 7.

${ }^{41}$ Ibidem, s. 6-7.

${ }^{42}$ Z. Ziembiński, Uzasadnienie twierdzeń ocen i norm w prawoznawstwie, PWN, Warszawa 1988, s. 67. 
Akt woli ma charakter intencjonalny. To stwierdzenie powoduje dość sporą konfuzję w doktrynie, ponieważ Kelsen nigdzie nie wyjaśnia, na czym owa intencjonalność miałaby polegać ${ }^{43}$. Hendrik van Eikema Hommes wyjaśnia przytoczoną definicję w następujący sposób:

O ile wola w znaczeniu psychologicznym może być skierowana intencjonalnie na zachowanie innych, o tyle norma (powinność) może być opisana jako znaczenie normatywne aktu intencjonalnego skierowanego na zachowanie innych ${ }^{44}$.

Wyjaśnienie zaproponowane przez van Eikema Hommesa wydaje się w sposób najprostszy wyjaśniać intencję Kelsena. Jednak być może warto pójść dość ewidentnym tropem, fenomenologii i przyjrzeć się pojęciu normy prawnej, w ujęciu jednego z fenomenologów zajmujących się prawem - Adolfa Reinacha. Jak wskazuje Tomasz Bekrycht, Reinach stał na stanowisku, że twierdzenia prawa pozytywnego są normami (co upodabnia jego teorię do kelsenowskiej), a te nie mogą pretendować do ścisłości naukowej. Według Reinacha możliwe jest jednak formułowanie sądów koniecznych na temat prawa pod warunkiem, że odstąpi się od tradycyjnego ujęcia na rzecz postawy fenomenologicznej. Zakłada to przyjęcie dwóch przesłanek: po pierwsze uznania oczywistości istnienia związków apriorycznych i po drugie niestawiania znaku równości między apriorycznością a subiektywizmem. Właśnie takie aprioryczne związki istnieją na gruncie prawa i zadaniem badacza jest ich odkrycie. Pomóc ma w tym idealizacja, której zadaniem jest ukazanie istoty ${ }^{45}$. Taka metoda pozwoliła Reinachowi w poszczególnych fazach redukcji na wyróżnienie przeżyć intencjonalnych (skierowanych na przedmiot) i nieintencjonalnych (nieskierowanych na przedmiot). Te pierwsze i zarazem interesujące z punktu widzenia Kelsenowskiej teorii Reinach dzieli na pasywne i aktywne. Ów podział jest wyodrębniony ze względu na rolę doznającego owych przeżyć, która jest albo pasywna (przeżycia oddziałują, ogarniają go) lub aktywna i wiąże się z działającym podmiotem ${ }^{46}$. Kolejny etap, czyli redukcja ejdetyczna do aktywności podmiotu dodaje inny czynnik - spontaniczność, w której, jak to ujmuje Reinach, „Ja okazuje się [być] fenomenalnym twórcą aktu” ${ }^{\text {"77 }}$. Bekrycht jako przykład takich aktów podaje: pytanie, wybaczanie, rozkazywanie ${ }^{48}$ i takie akty mogą zostać uzewnętrznione bądź nie. Jeśli zostaną uzewnętrznione, to potrzebny jest drugi podmiot, adresat aktu ${ }^{49}$. Jak wskazuje Bekrycht, wśród

${ }^{43}$ RR2, s. 5; C. Heidemann, Die Norm als..., s. 122.

${ }^{44}$ H.J. van Eikema Hommes, The Developmentof Hans Kelsen's Concept of Legal Norm, „Rechtstheorie” 1984, Bd. 5, s. 167.

${ }_{45}$ T. Bekrycht, Wstep, [w:] A. Reinach, Aprioryczne podstawy prawa cywilnego, thum. T. Bekrycht, Aureus, Kraków 2009, s. 17.

46 Ibidem, s. 20.

${ }^{47}$ A. Reinach, Aprioryczne podstawy..., s. 60.

48 T. Bekrycht, Wstęp, s. 20, przyp. 39.

49 A. Reinach, Aprioryczne podstawy..., s. 61. 
tego typu aktów można z kolei wyróżnić takie, w których obok odniesienia jest jeszcze zwracanie się do innego podmiotu, co wiąże się z wymogiem przyjęcia do wiadomości ${ }^{50}$. Reinach nazywa tego typu akty aktami społecznymi, przy czym mogą istnieć akty społeczne nierealizujące funkcji zwracania się do innego podmiotu $^{51}$. I właśnie do kategorii aktów społecznych zalicza Reinach prawo, które wymaga jeszcze pewnej responsywnej aktywności ${ }^{52}$. Czy taki opis prawa i norm prawnych może korespondować z definicją Kelsena? Moim zdaniem, tak, choć powinowactwo tych dwóch koncepcji będzie szczególnie widoczne w ostatniej fazie twórczości Kelsena, w której duży nacisk zostanie położny na wymiar językowy norm oraz akt wolicjonalny jako cechę konstytutywną normy prawnej. Wprawdzie dla Reinacha punkt wyjścia stanowi zupełnie inna metoda, brak jest dualizmu bytu i powinności, jednak sam opis prawa zawiera podobne elementy do tych wyróżnionych przez Kelsena, szczególnie w fazie językowo-analitycznej. Niewątpliwie jednak zamieszczenie przez Kelsena definicji nawiązującej do aktu intencjonalnego już w RR2 jest argumentem przemawiającym za tym, że już wtedy jego dążenie do wyeliminowania wątków neokantowskich było silne.

Kelsen stwierdza, że podmiot dokonujący aktu woli musi być wyposażony we władzę stanowienia norm ${ }^{53}$, jednocześnie zauważając, że:

Kiedy człowiek uzewnętrznia swój akt woli określając zachowanie się drugiej osoby poprzez nakaz, zakaz lub dozwolenie, to sens takiego aktu woli nie może zostać oddany poprzez stwierdzenie, że ta osoba będzie się zachowywać w określony sposób, ale, że powinna (soll) się zachowywać w określony sposób ${ }^{54}$.

Twórca czystej teorii prawa wskazuje, że w związku z tym słowo „powinien” jest tu użyte w szerszym kontekście, zawiera w sobie bowiem zarówno nakaz, zakaz, jak i dozwolenie ${ }^{55}$.

Akt woli może zatem przybrać postać rozkazu, dozwolenia i nadania kompetencji. Jednak, jak zauważa Hartney, ten rozkaz nie jest skierowany do organu mającego nałożyć sankcję, tylko do obywatela. Powoduje to, że norma posiada dwie funkcje. $Z$ jednej strony zawiera rozkaz skierowany do obywatela, $\mathrm{z}$ drugiej, kompetencje dla organu do nałożenia sankcji ${ }^{56}$. Zmienia to w sposób istotny nacisk na pewne cechy normy. Punkt ciężkości, który wcześniej z dużą

${ }^{50}$ Podział ten wydaje się przypominać teorię performatywów J.L. Austina i ich związki z funkcją prelokucyjną i illokucyjną, jednak jak zauważa Bekrycht jest to ujęcie o wiele szersze, ponieważ obejmuje swoim zasięgiem nie tylko akty mowy, ale i inne narzędzia komunikowania (T. Bekrycht, Wstęp, s. 21).

51 Ibidem, s. 20-21.

52 Ibidem, s. 21.

${ }^{53}$ RR2, s. 4.

54 Ibidem.

${ }^{55}$ Ibidem, s. 81.

${ }^{56}$ M. Hartney, Introduction..., s. XXXV. 
konsekwencją był położony na to, by wyeliminować obywatela z nauki prawa, teraz niebezpiecznie przesuwa się w jego stronę. To powoduje, że coraz trudniej uniknąć „psychologizowania” i coraz ciężej zachować podstawową tezę normatywizmu, czyli rozdział bytu i powinności.

Funkcja normy jako pochodna nakazu zakazu i dozwolenia oznacza, jak zauważa Hartney, że twierdzenie o normie - jako mającej zawsze taką samą postać i funkcję - zostało zastąpione przez stanowisko przeciwne. Rezultatem takiego ujęcia jest wprowadzenie pojęcia powinności sensu largo, a więc obejmującego nakaz, zakaz i dozwolenie ${ }^{57}$. Ogólnie rzecz biorąc, taka definicja normy prawnej, wprowadzając element woli, powoduje zbliżenie do siebie pojęcia normy i pojęcia rozkazu ${ }^{58}$.

Sama norma prawna może przybrać postać normy hipotetycznej lub kategorycznej. Normą hipotetyczną może być zarówno norma generalna, jak i indywidualna zawierająca powinność zastosowania aktu przymusu w określonym przez nią przypadku. Normą kategoryczną może być wyłącznie norma indywidualna zastosowana już bezwarunkowo ${ }^{59}$.

Na płaszczyźnie epistemologicznej, według Heidemanna, główną zmianą jest to, że obiekty nie są konstruowane w procesie poznania, lecz dane, zaś sąd poznawczy jest tylko reprodukcją niezależną od istniejącego obiektu. Heidemann przyznaje, że jego interpretacja jest dokonana wbrew twierdzeniom Kelsena, który utrzymywał, że pod tym względem nic się w jego koncepcji nie zmieniło ${ }^{60}$. Najważniejszym aspektem wspomnianej zmiany jest wyraźne rozróżnienie między normą prawną a zdaniem prawnym. Według tego normy są obiektem nauki prawa, natomiast sądy nauki prawa to zdania prawne ${ }^{61}$. Kelsen zdanie prawne definiuje następująco:

Zdania prawne są sądami hipotetycznymi, które artykułują, że w sensie [...] poznania określonego porządku prawnego, pod warunkami sformułowanymi w tym porządku prawnym, powinny nastąpić określone przez ten porządek prawny następstwa ${ }^{62}$.

Zatem zdania prawne przybierają następującą postać:

przy spełnieniu określonych warunków, mianowicie określonymi przez porządek prawny warunkami, powinien nastąpić skutek określony przez porządek prawny ${ }^{63}$.

${ }^{57}$ Ibidem, s. XXXIV.

${ }^{58}$ Ibidem, s. XXVIII.

${ }^{59}$ C. Heidemann, Die Norm als..., s. 130.

${ }^{60}$ C. Heidemann, Hans Kelsens Theorie normativer Erkenntnis, [w:] A. Brockmöller, D. Buchwald, D.V.D. Pfordten, K. Tappe (Hrsg.), Ethische und Strukturelle Herausforderungen des Rechts, Franz Steiner Verlag, Stuttgart 1997, s. 144.

${ }^{61}$ RR2, s. 73.

62 Ibidem, s. 73.

${ }_{63}$ Ibidem, s. 80. 
Kelsen zauważa, że nauka prawa jedynie opisuje prawo i nie może go tworzyć. Przykładem może być tu porównanie ustawy i komentarza do niej. Komentarz nie tworzy żadnej powinności, do niczego nie zobowiązuje. Jeśli nawet zawiera zdania powinnościowe, to są one prawdziwe lub fałszywe, natomiast nie mają znaczenia normatywnego (w silnym tego słowa znaczeniu). Prawdziwość i fałszywość zdań prawnych wynika z charakteru norm, które obowiązują lub nie. Jeśli więc zdanie prawne opisuje obowiązująca normę prawną, to jest zdaniem prawdziwym. Jeśli nieobowiązującą, to jest fałszywym ${ }^{64}$. Aby stwierdzić, czy dana norma obowiązuje, należy odwołać się do empirycznego faktu jej ustanowienia ${ }^{65}$.

Jak wskazuje Heidemann, rozróżnienie na normy prawne i zdania prawne wynika z podziału na płaszczyznę epistemologiczną i płaszczyznę obiektów (ontologiczną), gdzie zdania prawne należą do tej pierwszej, a normy do drugiej ${ }^{66}$. Mamy zatem dwa podziały: na świat przyrody i świat norm oraz płaszczyznę epistemologiczną i ontologiczną. Hartney wskazuje, że przy takim ujęciu zdań prawnych zmienia się funkcja nauki prawa ze względu na to, że opis norm nie jest tym samym, co przeformułowywanie ich. O ile w RR1 nauka prawa porządkowała materiał prawny i sprowadzała go do formy w postaci zrekonstruowanej normy prawnej: „Jeżeli A zrobi B, to organ C powinien nałożyć sankcję na A”, to teraz akcenty spoczywające wcześniej na normach prawnych zostały rozłożone między zdania prawne i normy. Według Hartneya, w rezultacie zdania prawne występują w formie zrekonstruowanej normy prawnej, podczas gdy normy niekoniecznie muszą ja przybrać ${ }^{67}$. Wydaje się, że jeśli odwołać się do znanej w Polsce siatki pojęciowej, przy rozróżnieniu normy i przepisu prawnego, w którym norma składa się $\mathrm{z}$ przepisów prawnych, to $\mathrm{w}$ pewnym uproszczeniu można byłoby stwierdzić, że kelsenowskie normy przypominają nasze przepisy prawne. Nie jest to do końca poprawne ujęcie, choćby dlatego, że dla Kelsena zdanie prawne niekoniecznie są opisem norm prawnych. Ponadto, zdanie prawne z oczywistych względów ekwiwalentem naszej normy prawnej być nie może, ponieważ pełni inne funkcje. Warto jednak zauważyć, że przytoczona wyżej norma prawna ma już silnie zdeterminowaną strukturę i trudno sobie wyobrazić rozbicie jej na części. Wydaje się zatem, że Hartney słusznie zadaje pytanie, jaką strukturę w tej sytuacji ma norma prawna i co z twierdzeniem, że normy prawne nakładają na organy obowiązek zastosowania sankcji ${ }^{68}$. Odpowiedzi można udzielić, wskazując, że dla Kelsena zdania prawne brzmią praktycznie tak samo jak normy. Zdanie prawne nie jest sformułowane w metajęzyku, nie opisuje - czego można byłoby oczekiwać - norm. Jak zatem ująć różnicę między normą prawną i zdaniem prawnym?

${ }^{64}$ Ibidem, s. 76.

${ }^{65}$ Ibidem.

${ }^{66}$ C. Heidemann, Die Norm als..., s. 122.

${ }^{67}$ M. Hartney, Introduction: The Final Form of the Pure Theory of Law, [w:] H. Kelsen, General Theory of Norms, trans. M. Hartney, Clarendon Press, Oxford 1991, s. XXIX.

${ }^{68}$ Ibidem, s. XXIX. 
Kelsen wskazuje, że norma prawna i zdanie prawne posiadają odmienny sens. Sensem zdania prawego jest rozpoznanie prawa i jego opis, natomiast sensem normy prawnej jest powinność ${ }^{69}$. Można zatem uzasadnić różnicę między tymi dwoma rodzajami wypowiedzi poprzez odwołanie się do pragmatyki ${ }^{70}$. W tym kontekście Kucsko-Stadlmayer wskazuje, że normy prawne mają funkcję perswazyjną, podczas gdy zdania prawne funkcję deskryptywną ${ }^{71}$. Zdanie prawne po prostu powtarza zawartość normy prawnej. Zawiera zatem w sobie powinność innego, wtórnego, opisowego charakteru wobec powinności będącej w normie prawnej o funkcji normatywnej ${ }^{72}$. Interesującą w tym kontekście analogię proponuje Hart. Należy sobie wyobrazić niemieckiego dozorcę w obozie jenieckim, który rozkazuje po niemiecku amerykańskiemu żołnierzowi wstać (Stehen Sie auf!). Tłumacz wypełniając swój obowiązek, krzyczy: „Stand up!”, tonem głosu jasno dając do zrozumienia, że chodzi o rozkaz. Hart zadaje pytanie, jak zakwalifikować akt mowy tłumacza. Nie był to rozkaz, ponieważ nie był on umocowany do wydawania rozkazów. Hart konkluduje, że w kelsenowskim świecie byłby to rozkaz w sensie deskryptywnym ${ }^{73}$.

Jak wskazuje Fritz Schreier, przy takim rozróżnieniu norm prawnych i zdań prawnych pojawia się problem: kto w sytuacji ,tłumaczenia” norm prawnych na zdania prawne powinien tego dokonać i w jaki sposób prawodawca powinien w związku z tym współpracować z prawnikiem ${ }^{74}$. Chodzi zatem o ustalenie postępowania, które miałoby doprowadzić do rozwoju porządku prawnego w pożądanym kierunku. Innymi słowy, wskazuje Schreirer, można wyróżnić trzy funkcje nauki o zdaniach prawnych ${ }^{75}$ : (1) normującą, (2) formułującą, (3) proceduralną. Nie są to pojęcia ostre, zaś ich zakresy krzyżują się. Jednego z kryteriów „dobrego zdania prawnego" upatruje Schrierer w takich określeniach, jak: zrozumiałość i jasność, zupełność i zamkniętość ${ }^{76}$ oraz brak luk i sprzeczności ${ }^{77}$.

Heidemann podsumowuje, że porównując fazę klasyczną z realistyczną, można zauważyć, że pierwsza z nich odwołuje się do idealizmu, a druga do realizmu. W realistycznej wersji Heidemann upatruje problem, polegający na tym, że nie da się wykazać, iż obiekty poznania są niezależne od niego. Jedyne, co jest

${ }^{69}$ RR2, s. 74.

${ }^{70}$ C. Heidemann, Die Norm als..., s. 123; M. Hartney, Introduction ..., s. XXXIII.

${ }^{71}$ G. Kucsko-Stadlmayer, Rechtsnormbegriff und Arten der Rechtnormen, Schriften des Hans Kelsen-Instituts, Wien 1992, s. 35.

${ }^{72}$ Ibidem.

${ }^{73}$ H.L.A. Hart, Kelsen Visited, „University of California Los Angeles Law Review” 1963, vol. 10, s. 716.

${ }^{74}$ F. Schreier, Rechtsnorm und Rechtssatz, Schriftenreihe des Hans Kelsen-Instituts, Wien 1982, s. 209.

75 Ibidem.

${ }^{76} \mathrm{~W}$ polskim prawodawstwie te dwa określenia podpadałyby pod jedną kategorię zupełności, gdzie zamkniętość, dotyczyłaby zupełności obowiązywania.

${ }^{77}$ Ibidem, s. 209. 
do udowodnienia, to fakt, że owe obiekty są niezbędne wewnątrz poznania ${ }^{78}$. Ponadto zwrócenie się w kierunku realizmu rodzi wątpliwość, jaki jest status norm prawnych w kontekście dualizmu bytu i powinności. Skoro są one niezależne od poznania, czyli poza poznaniem, to, czy można wykazać, że są dla poznania uchwytne nie wikłając się w sferę bytu? W przypadku pozycji idealistycznych tego problemu nie ma. Tam, z punktu widzenia poznania, sądami są zarówno normy, jak i fakty ${ }^{79}$. Nie jest moim zadaniem rozstrzyganie wszystkich tych wątpliwości, jednak zmiany dokonane w pojęciu normy prawnej w sposób istotny wpłynęły na pojęcie zarachowania i przypisania, które zostaną teraz kolejno omówione.

\subsection{Zarachowanie}

\subsubsection{Zarachowanie i zadośćuczynienie}

Zwątpienie Kelsena dotyczące kantowskiego ujęcia związku przyczynowo-skutkowego, a co za tym idzie neokantowskiej koncepcji poznania, ma swoje źródło w zainteresowaniu filozofią Hume'a i jego twierdzeniu, że przyczynowość jest rezultatem przyzwyczajenia, jednak sama w sobie koniecznego charakteru nie posiada. Takie ujęcie sprawia, że relacje między zarachowaniem a przyczynowością stają się niejasne. Kelsen w pewnym momencie stwierdza nawet, że również i zarachowanie jest przyzwyczajeniem myślowym, które w dodatku ma charakter ideologiczny, jednak z tej tezy szybko się wycofuje. Co naprowadziło Kelsena na takie wnioski? Kelsen twierdzi, że przyczynowość wywodzi się z wcześniejszej zasady zadośćuczynienia (będącej odmianą zarachowania), niemającej charakteru apriorycznej kategorii. W ten sposób, twierdzi Heidemann, Kelsen zbliża do siebie obie dotąd przeciwstawiane sobie zasady ${ }^{80}$. Nie jest moim zadaniem zagłębianie się w wątki etnologiczne opisane w Vergeltung und Kausalität. Kelsen zresztą najważniejsze twierdzenia z punktu widzenia czystej teorii prawa zawarł w RR2 ${ }^{81}$. Zatem wydaje się, że można ograniczyć się do tej syntezy. Kelsen na wstępie zwraca uwagę, że w myśleniu społeczeństw pierwotnych usiłujących wyjaśnić różne zjawiska z pewnością nie występowała zasada przyczynowości, która pojawiła się wraz z rozwojem cywilizacyjnym ${ }^{82}$. Zamiast tego człowiek pierwotny wszelkie fakty wiązał na tej samej zasadzie, która rządziła społecznymi normami, zasadzie zadośćuczynienia ${ }^{83}$. Przyjmowała ona następującą postać:

${ }^{78}$ C. Heidemann, Hans Kelsens..., s. 146.

79 Ibidem, s. 147.

${ }^{80}$ C. Heidemann, Die Norm als..., s. 118-119.

81 Jabloner nazywa „Vergeltung und Kausalität“ rozszerzeniem późniejszej syntezy zawartej w rozdziale Recht und Wissenschft (C. Jabloner, Bemerkungen zu Kelsens Vergeltung und Kausalität, besonderes zur Naturdeutung der Primitiven, „Rechtstheorie“ 1982, Bd. 4, s. 47.

${ }^{82}$ RR2, s. 86.

${ }^{83}$ Ibidem s. 86-87. 
jeśli zachowujesz się właściwie, powinieneś zostać nagrodzony, to znaczy: powinno tobie zostać uczynione dobro; kiedy zachowujesz się źle, powinieneś zostać ukarany, to znaczy: powinno być ci wyrządzone zło ${ }^{84}$.

Tym samym, wpleciono porządek natury w normatywny porządek społeczny ${ }^{85}$. Kelsen wskazuje, że w tej regule nie ma powiązania na zasadzie przyczynowości, tylko zarachowania, i jest to normatywne ujęcie natury. Złe zdarzenia, takie jak: choroba, wojna, były zarachowane jako kara za złe uczynki, zaś te dobre jako nagroda za dobre uczynki. Rodziły również pytania „kto jest za to odpowiedzialny?” i „kto nas nagradza i karze?”. Na to drugie pytanie ludzie pierwotni odpowiadali, że czynią to duchy i bóstwa ${ }^{86}$. Ludzie pierwotni zatem nie pytali się o przyczyny jakiegoś zdarzenia, ale o odpowiedzialność. Nie istniał podział na świat natury, którym rządziła zasada przyczynowości i świat społeczny z zasadą zarachowania. To, że taki podział później powstał, twierdzi Kelsen, jest rezultatem rozwoju duchowego, prowadzącego do podziału: człowiek - rzecz. Zatem obecna nauka jest rezultatem emancypacji świata przyrody w postrzeganiu człowieka, emancypacji, której narzędziem jest przyczynowość. Ów proces rozpoczął się w starożytnej Grecji, wraz z uświadomieniem sobie, że w świecie rzeczy zdarzenia dzieją się niezależnie od woli. Został jednak odwrócony w średniowieczu. Ponowną dyskusję na temat przyczynowości zainicjował dopiero Hume. Dzięki niemu, w nauce możliwy stał się postęp, który doprowadził do powstania nowoczesnych nauk przyrodniczych ${ }^{87}$. Kelsen wskazuje, że analogiczną krytykę jak w przypadku związku przyczynowo-skutkowego można przeprowadzić odnośnie do zarachowania, które nie dość, że jest przyzwyczajeniem myślowym, to ma również ideologiczny charakter ${ }^{88}$. Jak twierdzi Kelsen, do początków XX w. istniało przekonanie o konieczności powiązań przyczynowo-skutkowych ze względu na istnienie woli absolutnej o metafizycznym charakterze. Gdy to przekonanie osłabło, teoretycznie nic nie stało na przeszkodzie, by pozbawić przyczynowość koniecznego charakteru i nadać jej walor prawdopodobieństwa. Tak się nie stało, ponieważ miejsce woli absolutnej zajął postulat prawomocności ludzkiego poznania ${ }^{89}$. Po rozpoznaniu zasady przyczynowości zaczęła ona robić niezwykłą karie-

${ }^{84}$ Ibidem, s. 87.
85 Ibidem, s. 88.
${ }^{86}$ Ibidem, s. 87.
${ }^{87}$ C. Jabloner, Beitrage zurBeiträge zur einer Sozialgeschichte der Denkformen: Kelsen und die Einheitswissenschaft, [w:] C. Jabloner, F. Stadler (Hrsg.), Logische Empirismus und Reine Rechtslehre; Beziehungen zwischen dem Wiener Kreis und der Hans Kelsens-Schule, Veröffentlichungen des Instituts Wiener Kreis Springer, Wien, New York 2001, s. 25-37; C. Heidemann, Die Norm als..., s. 103.

${ }^{88}$ RR2, s. 110; C. Heidemann, Der Begriff der Zurechnung bei Hans Kelsen, [w:] S.L. Paulson, M. Stolleis (Hrsg.), Hans Kelsen Staatsrechtslehrer und Rechtstheoretiker des 20. Jahrhunderts, Mohr Siebeck, Tübingen 2005, s. 26.

${ }^{89}$ RR2, s. 88-89; wydaje się że Kelsen ma na myśli jedynie dziedzinę nauk przyrodniczych, a nie rozważania epistemologiczne. 
rę w wielu rodzajach nauk - również tych dotyczących człowieka, na przykład: w psychologii czy socjologii. W rezultacie podział między naukami przyrodniczymi a społecznymi zaczął się zacierać, a przynajmniej zmienił się jego punkt ciężkości - obecnie dotyczy on nauk, którymi rządzi zasada przyczynowości oraz nauk, do których odnosi się zarachowanie. Te drugie opisują normy i powstałe na ich podstawie relacje międzyludzkie. Nie ma tu powiązań koniecznych, są tylko mniej lub bardziej prawdopodobne powiązania skutku i następstwa ${ }^{90}$.

\subsubsection{Pojęcie}

Zarachowanie definiowane jest jako normatywne powiązanie konsekwencji naruszenia prawa $\mathrm{z}$ warunkiem prawnym (naruszeniem prawa) ${ }^{11}$. W ogólnych rozważaniach obejmujących nie tylko normy prawne Kelsen rozróżnia zarachowanie w znaczeniu wąskim - pierwotnym i szerokim. Zarachowanie w znaczeniu wąskim, pierwotnym zostało zdefiniowane następująco:

Zasada zarachowania - w swoim pierwotnym znaczeniu - łączy razem dwa akty ludzkich zachowań: zachowanie jakiegoś indywiduum z zachowaniem innego indywiduum, jak np. [...] karę z przestępcą ${ }^{92}$.

Z kolei zarachowanie w szerokim tego słowa znaczeniu odnosi się do sytuacji, gdy ma miejsce powiązanie faktów z ludzkimi zachowaniami. Następstwo wówczas jest zarachowane nie tylko osobie, ale również zewnętrznym okolicznościom. Kelsen dodaje, że jeśli chodzi o drugi element, to zarachować można tylko ludzkie zachowanie. Byłoby to zatem powiązanie pomiędzy warunkowym faktem a warunkowym ludzkim zachowaniem. Chodziłoby tu na przykład o sytuacje, w których rezultat zależy od wielu czynników, a zachowanie jest tylko jednym z wielu. Kelsen, ilustrując swoją tezę, wskazuje na zasadę miłosierdzia: „należy czynić wszystko, by ulżyć cierpiącemu w cierpieniu ${ }^{93}$.

Kelsen wskazuje, że w przypadku norm społecznych najczęściej w grę wchodzą normy kategoryczne (na przykład, „nie powinieneś kłamać”), nie zaś hipotetyczne. Gdyby miały one faktycznie kategoryczny charakter, to zarachowanie byłoby niemożliwe do zastosowania ze względu na to, że przy takiej ich budowie nie ma jak powiązać warunku i następstwa. Normy generalne, wbrew pozorom, nie są bezwarunkowe. Zawsze, nawet milcząco, norma zakłada jakieś warunki, okoliczności, w których ma się znaleźć adresat normy. Są to okoliczności, w których nakazane lub zakazane zachowanie jest możliwe. Od norm kategorycznych jest również szereg wyjątków, które ograniczają nakazy i zakazy. Warunek i następstwo

\footnotetext{
${ }^{90}$ Ibidem, s. 89-91.

91 Ibidem, s. 86; H. Kelsen, General Theory..., s. 92.

92 RR2, s. 104.

${ }_{93}$ Ibidem, s. 105-106.
} 
oraz ich powiązanie (zarachowanie) są zatem cechami konstytutywnymi każdej normy generalnej ${ }^{94}$. Z kolei w przypadku norm indywidualnych, kategoryczny ich charakter jest możliwy (choć niekonieczny), ponieważ mogą one nakazywać lub zakazywać określonego zachowania konkretnej jednostce bez wskazywania dalszych warunków, w których taka norma by obowiązywała (na przykład, gdy sąd orzeka karę wiezienia) ${ }^{95}$. Czy to oznacza, że w normach indywidualnych o kategorycznym charakterze brak zarachowania? Z powyższych rozważań i kelsenowskiej definicji tak by wynikało: brak tu jest dwóch elementów, które zarachowanie mogłoby wiązać. Zarachowanie zatem może być rozpatrywane w odniesieniu do norm generalnych i indywidualnych o charakterze hipotetycznym.

Definicja zarachowania peryferyjnego (teraz po prostu nazywanym przez Kelsena zarachowaniem) pozostaje co do zasady niezmieniona, brzmi podobnie do wcześniejszych: „powiązanie między warunkiem i następstwem wyrażonym gramatycznie poprzez słowo „powinien” ${ }^{96}$. Kelsen wskazuje, że relacja pomiędzy zachowaniem bezprawnym a następstwem takiego zachowania powstaje ze względu na to, że zachowanie jest bezprawne, ponieważ jest powiązane z jego następstwem (przymusem), a nie dlatego, że zachowanie bezprawne przedstawia delikt związany z aktem przymusu ${ }^{97}$.

Heidemann zwraca uwagę, że Kelsen napotyka dwojakiego rodzaju trudności w próbie wplecenia pojęcia zarachowania w system czystej teorii prawa ${ }^{98}$. Po pierwsze, ma problemy z jasnym zdefiniowaniem tego elementu; po drugie, nie jest w stanie w sposób jednoznaczny przyporządkować go sferze epistemologicznej czy też przedmiotowej. Wydawałoby się, że ze względu na charakter fazy realistycznej powinno się ono ograniczać tylko do sfery przedmiotowej, jednak można znaleźć fragmenty, w których Kelsen nawiązuje do epistemologicznego charakteru tej konstrukcji ${ }^{99}$. Jednak, jeszcze trudniej byłoby interpretować zarachowanie w duchu kantowskim, ze względu na kelsenowskie rozumienie przyczynowości, jakie pojawiło się w tym czasie. Jak wskazuje Dore, chodzi o to, że kantowska kategoria przyczynowości ma charakter formalny, podczas gdy Kelsen, odwołując się do słynnego przykładu empirycznego eksperymentu ${ }^{100}$, najwyraźniej postrzega przyczynowość jako bazującą na doświadczeniu ${ }^{101}$. Fakt ten przemawia zresztą za tym, by jednak utrzymać podział na cztery fazy, a nie trzy.

Warto wrócić do tego, co przedstawił Heidemann, że jeśli zarachowanie przyporządkowuje się sferze obiektów, to można je rozpatrywać na trzy sposoby,

\footnotetext{
${ }^{94}$ Ibidem, s. 106-107.

${ }^{95}$ Ibidem, s. 107.

96 Ibidem, s. 85

${ }^{97}$ Ibidem, s. 117.

98 C. Heidemann, Die Norm als..., s. 118.

99 Ibidem, s. 120.

100 RR2, s. 78.

${ }^{101}$ I.I. Dore, The Epistemological Foundations of Law, Carolina Academic Press, Durham
} 2007, s. 586. 
jako: (1) połączenie pomiędzy potencjalnymi stanami faktycznymi wyrażonymi w normie; (2) abstrakcyjne połączenie pomiędzy dwoma rzeczywiście danymi stanami faktycznymi poprzez normę; (3) konkretne przyporządkowaniem rzeczywiście danych stanów faktycznych ze względu na zastosowanie normy poprzez dowolnego poznającego prawo, który prawnie interpretuje rzeczywistość na podstawie normy jako schematu znaczeniowego ${ }^{102}$.

Jak już wykazano w poprzednim rozdziale, w tej fazie wchodzą dwie ostatnie możliwości. Być może uda się rozstrzygnąć, która $z$ nich jest tą właściwą, wyjaśniając, jak jest rozumiany stan faktyczny w tej fazie. Taką próbę podejmuje Hruschka. Analizując przykładową normę indywidualną dotyczącą skazania złodzieja za kradzież ${ }^{103}$, wskazuje, że w takim wyroku mamy do czynienia z dwoma stanami faktycznymi: warunkiem i następstwem. Warunkiem jest dokonanie zaboru cudzej rzeczy ruchomej w celu przywłaszczenia, a następstwem zamknięcie skazanego w więzieniu. Hruschka konkluduje, że te dwa stany faktyczne są w swej istocie dwoma konkretnymi faktami (Tatsache), zatem zarachowanie peryferyjne jest powiązaniem między dwoma faktami: jednym mającym miejsce w przeszłości (np. zabór złotego zegarka) oraz obecnym: (zamknięcie złodzieja w więzieniu).

W przypadku norm generalnych sytuacja przedstawia się nieco inaczej: mamy tu do czynienia z obiektywnym i subiektywnym stanem faktycznym. Obiektywny to dokonanie zaboru cudzej rzeczy w przypadku przestępstwa kradzieży. Natomiast subiektywny stan rzeczy, zawiera dodatkowo element woli przywłaszczenia jej. Na pierwszy rzut oka widać, że to nie są żadne fakty. Konkretne fakty dopiero będą podlegać subsumcji i wówczas można będzie o nich powiedzieć, że mamy do czynienia z zachowaniem odpowiadającym stanowi faktycznemu opisanemu w normie prawnej (tatbestandmassigen Handlung). Stan faktyczny jest sformułowaniem prawnym, opisem faktów, które określone zachowanie może urzeczywistnić ${ }^{104}$. Hruschka wskazuje, że Kelsen nie jest konsekwentny pod względem terminologii, gdy mówi o prawnym stanie faktycznym oraz prawnie przyporządkowanym mu konsekwencjach. Ma bowiem wówczas na myśli, w przypadku przestępstwa kradzieży wszelką kradzież mającą miejsce w przeszłości, teraźniejszości bądź przyszłości. Prawnie przyporządkowanymi konsekwencjami są wówczas wszelkie kary pozbawienia wolności za przestępstwa. Zarachowanie jest wtedy normatywnym powiązaniem dwóch klas stanów faktycznych ${ }^{105}$.

Heidemann dodaje, że zarachowanie łączy zawarunkowany stan faktyczny $\mathrm{z}$ następstwami o charakterze przymusu, z tym, że jako stan faktyczny rozumie nie tylko zachowanie niezgodne z prawem, ale również inne warunki niezbędne

102 C. Heidemann, Der Begriff der..., s. 27.

103 J. Hruschka, Die ZurechnungslehreKelsens in Vergleich mit der Zurechnungslehre Kants, [w:] S.L Paulson, M. Stolleis (Hrsg.), Hans Kelsen Staatsrechtslehrer und Rechtstheoretiker des 20. Jahrhunderts, Mohr Siebeck, Tübingen 2005, s. 5.

104 Ibidem, s. 6.

${ }^{105}$ Ibidem. 
dla zastosowania aktu przymusu, jak na przykład wniesienie aktu oskarżenia przez prokuratora ${ }^{106}$. W przypadku norm generalnych nie zawsze koncepcja zarachowania jest jasna. Według Renzikowskiego z kolei zarachowanie w normie generalnej ma charakter abstrakcyjny i analogiczny do zdań oznajmujących, wyrażających abstrakcyjny funkcjonalny związek pomiędzy dwoma stanami rzeczy. Inaczej jest z normami indywidualnymi, które Kelsen porównuje do stwierdzeń dokonanych $\mathrm{w}$ konkretnym eksperymencie. Zarachowanie $\mathrm{w}$ tym przypadku ma charakter konkretny i może się znajdować przykładowo w wyroku sędziego. Renzikowski zauważa w tym kontekście, że Kelsen odrzuca pojęcie subsumcji, twierdząc, że sędzia nie tylko stosuje prawa, ale poprzez swoją decyzję również je tworzy na mocy normy hierarchicznie wyższej i przypisania ${ }^{107}$. Renzikowski objaśnia to na przykładzie: osoba A jest zobowiązana zapłacić osobie B określoną kwotę, ale nie czyni tego. Osoba B odbiera pieniądze. Reakcja B powstała w odpowiedzi na zaniechanie A i miała formę przymusu wynikającego z sankcji. Warunkiem sankcji była możliwość zarachowania zaniechania B polegającego na niespełnieniu obowiązku wobec A. Zarachowanie tutaj nadaje normie charakter warunkowy (pod warunkiem, że A nie zapłaci B zostanie zastosowana wobec niego sankcja ${ }^{108}$. Hruschka zauważa na zakończenie, że chociaż pojęcie zarachowania dotyczy zarówno norm generalnych, jak i indywidualnych, to Kelsen, pisząc o zarachowaniu, ma głownie na myśli normy indywidualne ${ }^{109}$.

Znacznie więcej wątpliwości zdradza Heidemann, twierdząc, że sytuacja norm indywidualnych jest $\mathrm{z}$ tego punktu widzenia o wiele bardziej skomplikowana. Heidemann powołuje się tu na analogię, którą przeprowadził Kelsen między ogólną regułą, że podgrzewany metal zwiększa objętość i konkretnym naukowym eksperymentem, w którym konkretny metal zwiększył swoją objętość, a relacją między zdaniami prawnymi opisującymi normy generalne a zdaniami opisującymi normy indywidualne. Przykładowo, jeśli norma generalna stanowi, że gdy ktoś popełnił kradzież, to sąd powinien go skazać na karę więzienia, a zatem w odniesieniu do konkretnego przypadku zdanie opisujące normę indywidualną brzmiałoby: ,jeśli ktoś popełnił kradzież, to sąd X w Y, po tym jak ustali, że A popełnił kradzież, stosując akt przymusu skaże A na rok więzienia" "110. Heidemann zwraca uwagę, że owa analogia nie jest trafna z tego względu, że jeśli Kelsen chciał być konsekwentny, to opis normy indywidualnej powinien brzmieć następująco: „A popełnił przestępstwo kradzieży. Dlatego odpowiedni sąd powinien go ukarać" 111 . Jednak owo zdanie nie dotyczyłoby normy indywidualnej wydanej przez sędziego, tylko „skierowaną na samą siebie normę

\footnotetext{
106 C. Heidemann, Der Begriff der..., s. 21.

107 J. Renzikowski, Der Begriff..., s. 261.

108 Ibidem, s. 257.

109 J. Hruschka, Die Zurechnungslehre..., s. 6.

110 RR2, s. 85.

111 C. Heidemann, Der Begriff der..., s. 28.
} 
indywidualną, która jest logiczną konsekwencją zastosowania normy generalnej w konkretnym przypadku"112. Heidemann podsumowuje, że błąd Kelsena polega na tym, że w jego przykładzie sądu dotyczącego normy indywidualnej, zawarty jest punkt widzenia sędziego (ustawodawca ustanowił określone reguly prawne, które zastosował sąd ustalając, że A ukradł i skazując go na karę więzienia i faktycznie powinien być na taką karę skazany, podczas gdy Kelsen powinien uwzględnić punkt widzenia badacza, który stwierdza, że sankcja została faktycznie wykonana a następnie nadaje jej znaczenie prawne ze względu na istnienie odpowiedniej normy generalnej ${ }^{113}$.

Inną trudnością wiążącą się z przeformułowaniem teorii jest ustalenie relacji powinności i zarachowania. $\mathrm{W}$ fazie neokantowskiej zarachowanie i powinność były ze sobą silnie skorelowane. Teraz, jak wskazuje Heidemann, gdy Kelsen stwierdza, że powinność spełnia wielorakie funkcje: nakazu, zakazu, dozwolenia i upoważnienia, nie jest to już takie oczywiste. W szczególności funkcja dozwolenia powoduje istotne modyfikacje, ponieważ na jej podstawie sędzia ma kompetencję do wydania aktu przymusu. Powiązanie wyrażone zarachowaniem wydaje się mieć zatem inny charakter, aniżeli powiązanie tworzone przez powinność w funkcji dozwolenia i nie jest do końca jasne, jakie relacje są pomiędzy nimi. Heidemann konkluduje, że w ten sposób kategoria zarachowania zostaje wyparta przez kategorię powinności w funkcji dozwolenia ${ }^{114}$. Inaczej postrzega ten problem Alexy, wskazując, że pojęcie powinności można ujmować na dwa sposoby: jako pojęcie bazowe (Fundamentalbegriff) oraz pojęcie zbiorcze (Sammelbegriff). To pierwsze jest pojedynczą i nieredukowalną kategorią, pojęciem początkowym, mającym sens nietranscedentalny. Pozostałe modalności są wobec niej wtórne.

Z kolei pojęcie zbiorcze, czyli takie rozumienie powinności, w jakim używał go Kelsen w fazie realistycznej, dotyczy wszystkich równorzędnych modalności zebranych w Sollen ${ }^{115}$. Alexy, chcąc zweryfikować swoją tezę sprawdza, czy którąś z kategorii można uznać za bazową, koncentrując się przy tym na nakazie i dozwoleniu. W przypadku dozwolenia twierdzi, że odpowiedź tkwi w kelsenowskim rozróżnieniu norm pierwotnych oraz nom wtórnych. Według Alexego, modalnością zawartą w normie pierwotnej może być dozwolenie (kompetencja), co byłoby uzasadnione tym, że gdyby rozpatrywać w niniejszym kontekście nakaz, to (biorąc pod uwagę dynamiczną strukturę prawa) w końcu brakowałoby kolejnej instancji mogącej nałożyć sankcję w razie niewypełnienia nakazu ${ }^{116}$. Zatem ostatni organ mogący nałożyć sankcję musi być uprawniony,

112 Ibidem.

113 Ibidem, s. 29.

114 Ibidem, s. 30.

115 Warto zwrócić uwagę, że takie rozumienie powinności było raczej charakterystyczne dla trzeciej fazy, w której wpływy neokantowskie wyraźnie osłabły.

116 Wydaje się, że w praktyce można sobie taką sytuację wyobrazić. 
a niezobowiązany ${ }^{117}$. Alexy zauważa, że Kelsen pojęcie normy pierwotnej wprowadził po to, aby powinność prawną ściśle powiązać z aktem przymusu, podczas gdy kompetencja przymusu nie zawiera w sobie powinności. Jeśli rozpatruje się przymus w kontekście pytania o jego faktyczną możliwość wykonania, to wkracza się w sferę bytu. Uwidacznia się tym samym zależność normy pierwotnej od normy wtórnej i vice versa, co oznacza, że żadna z nich nie może być uznana za modalność źródłową. Kompetencja zatem nigdy nie może być aktualną powinnością, tylko potencjalną. Aktualną staje się dopiero przez wykonanie, co oznacza, że przypadku kompetencji, normatywność wprawdzie istnieje, ale jest zawieszona.

Problem ten nie występuje, jeśli zrezygnuje się z uznania kompetencji za modalność bazową. W normie pierwotnej występowałby wówczas zamiast kompetencji nakaz, a w normie wtórnej prawny nakaz pośredniczyłby we wprzęgnięciu modalności $\mathrm{w}$ strukturę zarachowania peryferyjnego. W rezultacie hipotetyczna i normatywna struktura zarachowania pozostałaby nietknięta i osiągnięta zostałaby czystość powiązania normy pierwotnej z normą wtórną ${ }^{118}$. Z wywodu Alexego wynika, że wszystkie modalności: nakaz, zakaz, dozwolenie i upoważnienie mają charakter równorzędny. Zatem, wydaje się, że wszystkie powinny odpowiadać zarachowaniu. $\mathrm{Z}$ pewnością nie ma tu problemu ani z nakazem, ani zakazem. Upoważnienie z kolei raczej dotyczy przypisania (ich relacje zostaną wyjaśnione później). Pozostaje kwestia dozwolenia. Czy zarachowanie peryferyjne w ogóle w nich występuje? Aby udzielić odpowiedzi na to pytanie, warto powrócić do tego, co zostało wcześniej powiedziane na temat norm dozwalających: dozwolenia wchodzą w skład pełnej normy prawnej i stanowią wyjątki od nakazów lub zakazów. Oznacza to, że zarachowanie ma miejsce, akt przymusu jest wykonywany, w stosunku do wszelkich podmiotów, które nie zostały objęte dozwoleniem. Pojawia się zatem tutaj pewna sprzeczność. Z jednej strony wszystkie modalności mają mieć ten sam status, $\mathrm{z}$ drugiej spełniają tak odmienne funkcje, że trudno powiedzieć, na czym ten równy status miałby polegać.

\subsubsection{Zarachowanie a zdanie prawne}

W fazie realistycznej Kelsen odchodzi od pozycji neokantowskich i przyjmuje tezę, że sąd poznawczy nie konstytuuje przedmiotu poznania, a jedynie jego równowartościową projekcję ${ }^{119}$. Pojawia się zatem rozróżnienie zdania prawnego

117 R. Alexy, Hans KelsensBegriff des relativen Apriori, [w:] R. Alexy, L.H. Meyer, S.L. Paulson, G. Sprenger (Hrsg.), Neukantianismus und Rechtsphilosophie, Nomos Verlagsgesellschaft, Baden-Baden 2002, s. 181-202, Warto wspomnieć, że na wstępie Alexy zauważa, że w tym określeniu słowo „relatywna” jest przysłówkiem odnoszącym się do przymiotnika „aprioryczny”, co sprawia, że przy takim sformułowaniu aprioryczność staje się przedmiotem gradacji (choć nic nie przemawia za tym, by można było uznać, że faktycznie tak jest). Ponadto, Kelsen używa również określenia „,relatywny", zatem konkluduje Alexy, prawdopodobnie użycie przysłówka było jedynie nieścisłością.

118 Ibidem, s. 202.

119 C. Heidemann, Der Begriff der..., s. 25. 
oraz normy prawnej, które w fazie neokantowskiej były ze sobą utożsamiane ${ }^{120}$. Zdania prawne można porównać ze zdaniami funkcjonującymi w naukach opartych na zasadzie przyczynowości. O ile w tych drugich schemat zdania przedstawia się jako: „kiedy A, to jest B”, to w naukach prawnych brzmi on następująco: „kiedy A, to powinno B”. Istnieje w nim powiązanie warunku i następstwa, czyli bezprawia i konsekwencji związanych z tym bezprawiem. Powiązaniem tym jest słowo „powinien”, lecz w innym znaczeniu aniżeli w normie prawnej, podczas gdy w zdaniach dotyczących świata natury będzie to ,jest”. „Jest” to przejaw powiązań przyczynowo-skutkowych. Jakie zatem powiązanie ma miejsce w zdaniach powinnościowych? Kelsen wyszedł z założenia, że zdanie prawne musi być wyrażone $\mathrm{w}$ formie logicznego związku pomiędzy warunkiem i następstwem, którym jest zarachowanie ${ }^{121}$, ponieważ skoro prawo bada się normatywnie, to również relacje prawne muszą być normatywie określane, a nie przyczynowo ${ }^{122}$. Zdaniem Heidemanna, przy takim podziale na płaszczyznę ontologiczną i epistemologiczną, rodzi się wątpliwość dotycząca zarachowania. Kelsen nie opowiada się jednoznacznie za tym, do której z tych płaszczyzn ono należy. Czasem stwierdza, że powiązanie na zasadzie zarachowania jest przez normę wytworzone, a w zdaniu prawnym opisane. Według Heidemanna, oznacza to, że zdanie prawne $\mathrm{z}$ normą jest powiązane dopiero poprzez zarachowanie ${ }^{123}$. Trudno na to pytanie udzielić jednoznacznej odpowiedzi, ponieważ - jak wskazuje Heidemann - Kelsen raczej opowiada się za drugim rozwiązaniem, aczkolwiek zdarza mu się nawiązywać i do pierwszego ${ }^{124}$.

Warto zatem sprawdzić, w jaki sposób do tego zagadnienia podchodzi doktryna. Wydaje się, że można wyróżnić trzy możliwości: po pierwsze, zarachowanie znajduje się zarówno w normie prawnej, jak i w zdaniu prawnym; po drugie zarachowanie dotyczy normy prawnej; po trzecie, zarachowanie dotyczy zdania prawnego. Za pierwszą możliwością, jak wskazuje Wróblewski, opowiadają się na przykład przedstawiciele egologicznej teorii prawa, czyniąc z tego zarzut, iż w ten sposób dochodzi do podwojenia logicznego pojęcia zarachowania. Odrzucają oni jednocześnie dwie pozostałe możliwości. Powinność znajdująca się tylko w zdaniu prawnym, prowadzi do sprzeczności z poznawczymi założeniami normatywizmu ${ }^{125}$. Można zatem przyjąć, że w istocie mamy do czynienia z dwoma rodzajami zarachowania, które można nazwać preskryptywnym i deskryptywnym. Zarachowanie preskryptywne jest łącznikiem między warunkiem i następstwem,

${ }^{120}$ Ibidem.

121 J. Hruschka, Die Zurechnungslehre..., s. 3-4; C. Jabloner, Beitrage zur..., s. 23.

122 J. Wróblewski, Krytyka normatywistycznej normatywistycznej teorii prawa i państwa Hansa Kelsena, PWN, Warszawa 1955, s. 145.

${ }_{123}$ C. Heidemann, Die Norm als..., s. 123; idem, Der Begriff der..., s. 25.

${ }^{124}$ C. Heidemann, Der Begriff der..., s. 25.

125 J. Wróblewski, Egologiczna teoria prawa przeciw czystej teorii prawa, „Państwo i Prawo” 1959, nr 8-9, s. 311. 
natomiast deskryptywne miałoby funkcję poznawczą. Można zatem postawić pytanie: czy przy takim ujęciu zarachowanie preskryptywne nie byłoby pozbawione znaczenia, ponieważ przy opisowym charakterze zdań prawnych, nie jest potrzebne do identyfikacji normy prawnej? Wydaje się jednak, że funkcją zarachowania deskryptywnego mogłaby być funkcja odróżnienia zdań nauki prawa od zdań przyrodoznawstwa. Z takim podejściem zgadza się Hruschka, wskazując, że konstrukcja zarachowania bierze swój początek u Kelsena z odróżnienia norm prawnych od zdań prawnych ${ }^{126}$. Normy prawne są wydawane przez kompetentny autorytet, są funkcją prawa tworzonego przez odpowiedni organ, natomiast zdania prawne wywodzą się z nauk prawnych, są funkcją prawa opisanego jako nauka prawa ${ }^{127}$. Normy prawne zawierają nakazy, zakazy i dozwolenia, zaś zdania prawne są hipotetycznymi sądami, poprzez które nauka prawa opisuje stan prawny. Są one sformułowane następująco: ,jeżeli zostało popełnione bezprawie, to odpowiednie konsekwencje (sankcja) powinny być poniesione" 128.

$\mathrm{W}$ obu rodzajach wypowiedzi mamy do czynienia z pojęciem powinności, jednak w innych znaczeniach. W normie prawnej słowo „powinien” jest nakazem, jak należy bądź nie należy czynić. Z kolei w zdaniu prawnym, sformułowanie „powinien” pełni rolę opisową. Norma prawna może być wyłącznie obowiązująca lub nie, natomiast zdanie prawne może być prawdziwe bądź fałszywe, zatem jest zdaniem w sensie logicznym, podczas gdy nie może być obowiązujące lub nieobowiązujące. Na poparcie tej tezy można przytoczyć słowa Kelsena:

kiedy zdanie prawne jest sformułowane w ten sposób, że pod określonymi warunkami powinien nastąpić określony skutek, to znaczy: kiedy przez normę zostaje stworzone połączenie warunku i następstwa określonych stanów faktycznych w zdaniu prawnym, to jest to wyrażone poprzez słowo ,powinien"129.

Wydaje się, że z przytoczonego fragmentu wynika, że norma prawna „wytwarza" zarachowanie, podczas gdy zdanie prawne zawiera opis tego, co zarachowanie łączy. Co jednak oznacza stwierdzenie, że norma „wytwarza zarachowanie"? O przejęzyczeniu, czy niekonsekwencji nie może być mowy, ponieważ można znaleźć podobne fragmenty w innych publikacjach Kelsena. Na przykład w Kaisalität und Zurechnung Kelsen stwierdza, że:

W zdaniach prawnych opis połączeń między bezprawnym faktem a jego następstwem, utworzonymi przez normy prawne, jest aktem poznania, a nie woli [...]. Jego funkcją jest opis, a nie nakaz będący funkcją tworzenia prawa przez organ ${ }^{130}$.

126 J. Hruschka, Die Zurechnungslehre..., s. 3.

127 R. Hendler, Die Staatstheorie Hans Kelsens, Juristische Schulung, C.H. Beck, München 1972, s. 490.

128 Ibidem.

129 RR2, s. 80-81.

${ }^{130}$ H. Kelsen, Kausalität und Zurechnung, „Österreiches Zeitschrift für Öffentliches Recht und Völkerrecht" 1954, vol. VI, no. 2, s. 128. 
Z przedstawionego cytatu wynika, że połączenie (czyli zarachowanie) zostało przez normę „,wytworzone”. Takie określenie wydaje się wskazywać na to, że zarachowanie jest czymś zewnętrznym wobec normy, choć bardziej intuicyjne wydaje się przyjęcie, że zarachowanie, łącząc te dwa zdania, tworzy nową jakość - normę. Jednak tak nie jest, to norma bowiem tworzy zarachowanie. Przy okazji uniemożliwia to postrzeganie zarachowania jako elementu normy, chyba że się przyjmie, że norma wytwarza zarachowanie jako jeden ze swoich elementów wewnątrz siebie. Wówczas jednak można byłoby postawić pytanie retoryczne, czy czasem Kelsen nie inspirował się metafizyczną koncepcją leibnizowskiej monady. Być może rozwikłanie zagadki przyniesie kolejny cytat:

Ta powinność wyraża specyficzny sens w tym, że dwa stany faktyczne są ze sobą połączone poprzez normę prawną, to znaczy: w normie ${ }^{131}$.

Norma prawna z jednej strony wytwarza zarachowanie, z drugiej je zawiera (ponieważ powinność jest językowym przejawem zarachowania). Jak zatem wyjaśnia Kelsen, obecność zarachowania, które jako zdania nauki prawa o obowiązywaniu lub nieobowiązywaniu norm wydają się statuować byt? Według Kelsena, owe zdania bynajmniej nie mają takiego charakteru, ponieważ stwierdzając, że norma ustanawiająca powinne zachowanie obowiązuje, nie ma się na myśli, że takie zachowanie faktycznie ma miejsce, tylko, że powinno mieć miejsce ${ }^{132}$. Rozwiązanie tego problemu proponuje van Eikema Hommes, wskazując, że jest to relacja między dwoma faktami poprzez zasadę prawną i jest identyczna z transcendentalno-logiczną formą poznania konstytuującą powinnośćc ${ }^{133}$. Rozwiązanie to jednak angażuje wątki neokantowskie. W rozwikłaniu zagadki: co Kelsen ma na myśli, twierdząc, że norma wytwarza zarachowanie, może pomóc odwołanie się do pierwszej fazy, w której takie sformułowanie również padało. Wtedy było ono w miarę jasne ze względu na kontekst, w którym było osadzone. Kelsen twierdził bowiem, że norma jest zasadą zarachowania i w tym sensie wytwarza je.

Wydaje się, że sam podział na zarachowanie preskryptywne i deskryptywne jest w miarę spójny. Czy jednak jest możliwy na gruncie neokantyzmu, zostanie wyjaśnione poniżej.

\subsubsection{Zarachowanie jako relatywna kategoria a priori?}

Wątek transcendentalny w fazie realistycznej wydaje się budzić najwięcej kontrowersji. Aby chociaż częściowo rozstrzygnąć ów problem, należy postawić pytanie, czy zarachowanie jako relatywna kategoria a priori jest możliwe po tym, jak Kelsen dokonał podziału na normę prawną i zdanie prawne.

\footnotetext{
131 RR2, s. 81.

132 Ibidem, s. 81-82.

133 H.J van Eikema Hommes, The Development..., s. 169.
} 
Twierdzącej odpowiedzi udziela Renzikowski, według którego zasada zarachowania dotyczy zdania prawnego, gdzie jest wyrażone przez słowo „powinien”. $\mathrm{W}$ ten sposób zasada zarachowania w nauce prawa staje się kategorią rozumu, analogiczną do kategorii przyczynowości, która konstytuuje określoną normę generalną ${ }^{134}$. Za tezą Renzikowskiego przemawiałoby to, że samo poznanie wciąż po kantowsku konstytuuje swój obiekt w tym sensie, że porządkuje alogiczny materiał tak, że z chaosu wyłania się kosmos ${ }^{135}$, a samo pojęcie relatywnej kategorii a priori wciąż jest w pismach Kelsena obecne, w RR2 jako norma podstawowa czy też w Was ist die Reine Rechtslehre? ${ }^{136}$. Mimo, że jego znaczenie słabnie i coraz bardziej wchodzi w rolę reliktu. Jeśli zatem przyjąć, że Renzikowski ma rację, to rodzi się pytanie: jak relatywna kategoria a priori miałaby wyglądać w fazie realistycznej? Pewną wskazówkę można znaleźć w Science and Politics. Kelsen pisze tam o zarachowaniu w znajomy sposób: jako kategorii analogicznej do kategorii przyczynowości z logiki transcendentalnej Kanta. Zarachowanie w tym kontekście Kelsen odnosi do zdań prawnych ${ }^{137}$. W związku z tym można zadać kolejne pytanie: jaki jest status norm prawnych? Jeśli trzymać się analogii kantowskiej, to musiałyby one odpowiadać rzeczom samym sobie, noumenom, alogicznemu materiałowi, który dopiero byłby porządkowany przez umysł, w tym przez kategorie. Wynikałoby z tego, że w normach prawnych kategoria zarachowania nie mogłaby występować, ponieważ tak jak przyczynowość nie należy do świata noumenów. W takim wypadku, należałoby chyba jednak odmówić pełnej normie prawnej (której „alogicznym materiałem” nazwać nie można) zdolności funkcjonowania na płaszczyźnie norm i przyjąć, że jest ona zdaniem prawnym. Cała wizja porządku prawnego u Kelsena zaczęłaby przypominać przywołane już wcześniej rozróżnienie między przepisem prawnym i normą prawną, językiem prawnym i prawniczym. Kelsenowskie normy prawne w takiej interpretacji byłyby rozumiane jako tekst prawny.

Z kolei zdania prawne byłyby skonstruowanymi z przepisów prawnych normami prawnymi. Wtedy jednak nie wiadomo byłoby, jaki charakter miałby mieć łącznik zawarty w przepisie prawnym zbudowanym z hipotezy i sankcji. Wydaje się, że na gruncie tej interpretacji należałoby mu odmówić cechy zarachowania. Ponadto, w ten sposób zanika spójny podział na zarachowanie deskryptywne

134 J. Renzikowski, Der Begriff der,,Zurechnung” in der Reinen Rechtslehre Hans Kelsens, [w:] R. Alexy, L.H. Meyer, S.L. Paulson, G. Sprenger (Hrsg.), Neukantianismus..., s. 260-261, warto przypomnieć, że innego zdania jest Heidemann, według którego co najmniej nie do końca jasne jest, czy w fazie realistycznej argument transcendentalny wraz z kategorią zarachowania może mieć miejsce.

135 RR2, s. 74.

${ }^{136}$ H. Kelsen, Was ist die Reine Rechtslehre?, [w:] Demokratie und Rechtstaat, Polygraphischer Verlag A.G., Zürich 1953, s. 144.

${ }^{137}$ H. Kelsen, Science and Politics, „The American Political Science Review” 1951, vol. XLV, s. 652. 
i preskryptywne. Zanim jednak postawi się taką tezę, warto sprawdzić, co Kelsen ma do powiedzenia na ten temat. Normy prawne są obiektami nauki prawa, „funkcją organu prawnego"138, czyli funkcją woli.

Dalej Kelsen ogranicza się do stwierdzenia, że zadaniem naukowca jest opis prawa i jego poznanie. To stwierdzenie Kelsena niczego nie wyjaśnia, jednak wydaje się możliwe zaryzykowanie stwierdzenia, że norma prawna jako „funkcja organu prawnego", czyli funkcja woli, nie przypomina w niczym kantowskiej konstrukcji rzeczy samej w sobie. Jej różnica wobec zdań prawnych wyraża się w funkcjach, a nie w istocie. W ATN te funkcje zaczną być rozpatrywane na płaszczyźnie językowej, pragmatyki. Ponadto, jak już wcześniej zostało podkreślone, za uznaniem, że zarachowanie dotyczy zarówno norm prawnych, jak i zdań prawnych, przemawiają silne argumenty a taka interpretacja oferuje dość spójny obraz. W rezultacie można stwierdzić, że Kelsen nie chcąc „pożegnać się” z argumentem transcendentalnym, starał się do niego dopasować nową koncepcję.

Argumentem przemawiającym za tą tezą może być fakt, że rozpatrując dynamiczną strukturę prawa, Kelsen w pewnym momencie buduje bardzo ciekawą analogię. Stwierdza bowiem, że z jednej strony postępowanie sądowe, którego rezultatem jest sankcja, nie jest poznaniem prawnym, z drugiej, że mimo to można doszukać się tu pewnych podobieństw do poznania w świecie przyrody. Uzasadnienie dla tych podobieństw w świecie przyrody można znaleźć na kilku płaszczyznach. Po pierwsze, podmiotu poznania i organu przeprowadzającego postępowanie, po drugie, tak jak obiekt poznania jest w nim ukonstytuowany, tak w postępowaniu sądowym ukonstytuowana jest sankcja. Po trzecie, tak jak poznanie jako fakt samo może stać się przedmiotem poznania, tak postępowanie sądowe może stać się przedmiotem innego postępowania sądowego ${ }^{139}$. Nie ulega wątpliwości, że występuje tu nawiązanie do neokantowskiej teorii poznania. $\mathrm{W}$ tym procesie rezultatem jest sankcja związana $\mathrm{z}$ aktem przymusu, czyli jeden z elementów, które łączy zarachowanie. Czy zatem przedstawiona przez Kelsena analogia jest kolejnym sygnałem ostrożnego wycofywania się $\mathrm{z}$ argumentu transcendentalnego? Wydaje się, że przede wszystkim widać tu coraz większy sceptycyzm wobec neokantowskich koncepcji, podczas gdy wcześniej można było odnieść wrażenie, że Kelsen powołuje się na neokantyzm w myśl zasady „gdzie się da”. Na tym przykładzie zatem widać wyraźnie to, o czym pisze Heidemann: Kelsen stopniowo porzuca wątki neokantowskie, staje się wobec nich sceptyczny. Co zatem z argumentem transcendentalnym? Z jednej strony Kelsen wciąż pisze o relatywnych kategoriach a priori, z drugiej, po wprowadzeniu zdań prawnych, zarachowanie jako taka kategoria wydaje się tracić sens. Może być to zresztą powodem wyboru normy podstawowej w RR2 jako spełniającej tę funkcję. W tym kontekście jest to lepszy wybór, ponieważ podział na zdania prawne

\footnotetext{
138 Ibidem.

139 RR2, s. 247.
} 
i normy prawne nie wydaje się jej bezpośrednio dotyczyć. Funkcją nadal pozostaje zapewnienie jedności porządku prawnego, a jako założenie poczynione w umyśle świetnie pasuje do kantowskiej charakterystyki kategorii. Również kategoria powinności jako prawdziwość świetnie, nawet lepiej niż w fazie neokantowskiej, odnajduje się w roli relatywnej kategorii a priori. Jak już zostało wcześniej wskazane, zaproponowana przez Alexego interpretacja znakomicie współgra z podziałem na zdania i normy prawne.

Podsumowując, konstrukcja zarachowania uwypukla spostrzeżenie, że faza realistyczna ma charakter przejściowy. Widać, jak czysta teoria prawa przeobraża się: ewoluuje od neokantyzmu w kierunku filozofii analitycznej. Owa ewolucja powoduje jednocześnie wiele niespójności w samej strukturze teorii. Wydaje się, że są one nawet większe niż w HP, gdzie na poziomie struktury teoria była w miarę spójna, problem raczej sprowadzał się do tych elementów, które zostały w niej pominięte.

\subsection{Przypisanie}

W samej konstrukcji zarachowania centralnego niewiele się zmieniło poza nazwą. W tej fazie Kelsen rezygnuje z określenia „zarachowanie centralne” na rzecz „przypisania”, uznając, że wcześniejsza terminologia nie była zadowalająca ${ }^{140}$. Jak wskazuje Heidemann, pojęcie to wciąż jest dwuznaczne. Jedni doczytują się w nim związku z osobą, inni związku praw i obowiązków z osobą ${ }^{141}$. Kelsen zauważa również, że przypisanie jest:

operacją myślową, która może zostać przeprowadzona, ale w żadnym razie nie musi, ponieważ na pytania [...] w tym zakresie można odpowiedzieć bez pomocy tej operacji myślowej [...] ze względu na swój fikcyjny charakter ${ }^{142}$.

Z przytoczonego cytatu wynika, że przypisanie nie jest koniecznym elementem jego teorii. Jego zadaniem jest wyłącznie wyjaśnienie innych elementów. Potwierdza się zatem to, co napisał Paulson: Kelsen praktycznie rezygnuje z przypisania, zastępując je innymi elementami ${ }^{143}$.

Przypisanie można rozpatrywać w kontekście statycznych aspektów prawa (w odniesieniu do podmiotów prawa) oraz jego dynamiki (dynamiczna struktura prawa). Szczególnie tej pierwszej grupie zagadnień Kelsen poświęcił znacznie więcej uwagi $\mathrm{w}$ porównaniu z poprzedną fazą. Warto zatem prześledzić, co Kelsen pisze o przypisaniu w aspekcie statycznym. Lippold wyróżnia trzy aspekty

${ }^{140}$ Ibidem, s. 151, przyp. 1.

${ }_{141}$ C. Heidemann, Die Norm als..., s. 131.

142 RR2, s. 185.

143 S.L. Paulson, Hans Kelsen's Earliest Legal Theory: Critical Constructivism, „Modern Law Review" 1996, vol. 59, s. 811. 
odnoszące się do: osób fizycznych, organów osoby prawnej i państwa. W szczególności te dwa pierwsze wątki zostały w stosunku do wcześniejszej fazy szerzej rozwinięte w RR2. Na wstępie Kelsen stwierdza, że pojęcie podmiotu prawnego jest konstrukcją wyłącznie pomocniczą, którą można się posługiwać, jeśli zna się jej sens. Tak naprawdę nie chodzi tu o podmiot prawa, tylko o jego zachowania opisane w normach prawnych ${ }^{144}$.

Odmiennym przypadkiem jest przedstawicielstwo. Kelsen wskazuje, że jest to pojęcie pokrewne z pojęciem organu. Różnica polega na tym, że przedstawicielstwo dotyczy osoby niezdolnej do czynności prawnych, które tak jakby wypełniają swoje prawa i obowiązki nie osobiście, lecz przez przedstawiciela. Sformułowanie „tak jakby” wskazuje na fikcję przypisania. Ta fikcja zarówno w przypadku organu, jak i przedstawicielstwa polega na tym, że w rzeczywistości inna osoba dokonuje czynności prawnych, niż wynikałoby to z prawa. Obok tego wyróżnia Kelsen pełnomocnictwo, które w przeciwieństwie do poprzednich ani nie jest obligatoryjne, ani bezpośrednie. Pełnomocnictwo charakteryzuje się również tym, że nie ma tam przypisania, ponieważ prawa i obowiązki nie są mu W sposób fikcyjny przypisane, tylko faktycznie przechodzą na niego ${ }^{145}$.

Odnośnie do organów Kelsen wpierw zamieszcza uwagi ogólne dotyczące zarówno organów osób prawnych, jak i organów państwa. Na wstępie pisze: „organem określonej wspólnoty jest indywiduum, o ile wykonuje funkcje, które wspólnota może mu przypisać"146. Kryje się za tym pewna fikcja, ponieważ działania wspólnoty są podejmowane przez konkretne osoby. Wspólnota powstaje jako zbiorowość jednostek, której zasady funkcjonowania są opisane przez normatywny porządek. Konkretny człowiek jest organem wspólnoty, o ile następuje przypisanie jej zachowań wspólnocie. Przypisanie jest, podsumowuje Kelsen, funkcją wspólnoty ${ }^{147}$. Kelsen wskazuje, że istnieje tendencja do przypisywania wyłącznie zachowań, które są albo nakazane, albo dozwolone. Delikty popełnione przez jednostkę nie są wspólnocie przypisywane ${ }^{148}$. Jak wskazuje w tym kontekście Lippold, na gruncie prawa przypisanie w odniesieniu do organów można rozpatrywać z dwóch punktów widzenia.

Po pierwsze, przypisanie tworzy powiązanie pomiędzy osobą prawną i jej organem, co pozwala zidentyfikować zachowania danego człowieka jako zachowania organu. W przypadku państwa i w niektórych sytuacjach w przypadku osób prawnych oznacza to, że jeśli taka osoba przekroczy swoje umocowanie, to jej działania organowi państwowemu się nie przypisuje, ponieważ prowadziłoby to do sprzeczności ${ }^{149}$. W przypadku osób prawnych oznacza to, że do przypisania

144 RR2, s. 173.

145 Ibidem, s. 164.

146 Ibidem, s. 152.

147 Ibidem, s. 152-153.

148 Ibidem, s. 153-154.

149 Ibidem, s. 185, 305-307. 
ludzkiego działania organowi dochodzi wyłącznie wtedy, gdy owo zachowanie jest uwzględnione w statucie ${ }^{150}$.

Po drugie, na drodze zarachowania nadzwyczajnego, pod określonymi warunkami, możliwe jest przypisanie osobie prawnej działania osoby, która przekroczyła swoje uprawnienia ${ }^{151}$.

W przypadku osób fizycznych nie zmieniło się wiele od czasów HP. Osoba nadal jest konstrukcją o charakterze prawnym, pojęciem pomocniczym. Tym, co sprawia, że człowiek znajduje się w obrocie prawnym, jest przypisanie mu praw i obowiązków ${ }^{152}$. Kelsen pisze: „być osobą albo posiadać osobowość prawną jest identyczne z obowiązkami prawnymi i posiadaniem subiektywnych obowiązków prawnych" 153 .

Kelsen wprowadza również pojęcie organu w wąskim ujęciu, wskazując, że do przedstawionej wyżej definicji należałoby dodać, że organem może być tylko taka jednostka, która ma określone kwalifikacje (moralne, zdrowotne, umiejętności itd.). Wówczas można mówić o zorganizowanych wspólnotach ze względu na istniejący $w$ nich podział pracy ${ }^{154}$. Szczególnym rodzajem kwalifikacji jest, według Kelsena, powołanie (na przykład na urząd prezydenta). Wymóg tego typu kwalifikacji jest charakterystyczny dla szczególnego rodzaju wspólnoty - państwa, w którym ,akty państwa jako osoby prawnej mogą być wyłącznie aktami ludzkimi, przypisanymi państwu jako personifikacji porządku prawnego" ${ }^{155}$. Podstawowym pytaniem zadawanym przez Kelsena w odniesieniu do organów państwowych jest: dlaczego niektóre działania ludzkie są postrzegane jako działania organów? Kelsen wskazuje, że przypisanie zachowania określonej osoby państwu wchodzi w grę, ponieważ sprowadza się ono do stwierdzenia, że to zachowanie jest określone jako warunek lub następstwo ${ }^{156}$. Kelsen zaznacza, że tym samym państwo, tak samo jak osoba prawna, jest jedynie konstrukcją pomocniczą (państwo jest tożsame prawem). O każdej funkcji państwa można powiedzieć, że nadaje państwu cechę osoby, zaś funkcja określona jest w porządku prawnym. Państwo jako osoba jest niczym innym jak ,personifikacją porządku prawnego"157.

Kelsen wskazuje, że jest to pewna metafora, pomocna, ale niekonieczna do adekwatnego opisu prawa. Problem państwa jako osoby podejmującej działania to tak naprawdę problem przypisania, które uwidacznia się podczas odpowiedzi na pytanie, czy określona funkcja jest funkcją państwa. Kelsen wskazuje, że można to ustalić poprzez sprawdzenie, czy w użyciu języka ta funkcja

150 Ibidem, s. 186.

151 R. Lippold, Reine Rechtslehre und Strafrechtdoktrin, Springer Verlag, Wien, New York 1989, s. 116.

152 Ibidem, s. 115.

153 RR2, s. 177.

154 Ibidem, s. 155-156.

155 H. Kelsen, Was ist..., s. 156.

156 RR2, s. 294.

157 Ibidem, s. 296. 
jest państwu przypisana. Pytanie zatem brzmi: pod jakimi warunkami w języku prawniczym określone w porządku prawnym funkcje można państwu przypisać. Państwu można przypisać określoną funkcję, odpowiada Kelsen, kiedy nadano jej znaczenie funkcji państwa. Określona osoba postrzegana jest jako organ sprawujący tę funkcję wtedy, gdy w odpowiednim postępowaniu została przez państwo do tego powołana ${ }^{158}$. Jak wskazuje Kelsen, od tego pojęcia należy odróżnić inne pojęcie państwa, ściśle z tamtym związane. O ile przed chwilą omawiane pojęcie dotyczyło państwa jako pewnej całości porządku prawnego, tworzącego wspólnotę prawną, do której należą wszyscy żyjący na jej terenie ludzie, o tyle tym razem chodzi o część tego porządku, w którym określonym normom podlegają określeni obywatele-urzędnicy. Ów częściowy porządek prawny konstytuuje odpowiadającą mu wspólnotę, której zostaną przypisane wyłącznie funkcje jej członków. Kelsen wskazuje, że chodzi mu tu o państwo jako aparat urzędniczy z rządem na szczycie tej piramidy ${ }^{159}$. Zagadnienia poruszone przez Kelsena podczas rozważań na temat osób prawnych i tu są aktualne, ale dochodzą nowe elementy ze względu na dobrze znany trójpodział władzy: ustawodawczą, wykonawczą i sądowniczą, które zawierają się w szerszych kategoriach, tworzenia i stosowania prawa, natomiast określone działania przypisywane są konkretnemu organowi $\mathrm{i}^{160}$.

Heidemann z kolei wskazuje na zmianę polegającą na dokonaniu powiązania pojęcia dozwolenia z pojęciem przypisania. Dodatkowo, dozwolenie rozumiane jest szeroko, nie tylko jako możliwość stanowienia prawa, ale również możliwość podejmowania prawnie relewantnych zachowań. Heidemann podkreśla na niekonsekwencję tego ujęcia polegającą na tym, że z jednej strony, porządek prawny upoważnia również do popełniania deliktów, co oznacza, że naruszenie obowiązków może być przypisane osobie, a z drugiej, Kelsen w odniesieniu do osób prawnych twierdzi, że nie można im przypisać aktów bezprawnych ${ }^{161}$.

Rozważania dotyczące relacji, która łączy zarachowanie centralne i dynamiczną strukturę prawa są aktualne również tutaj, a więc nie ma potrzeby powtarzania ich. Nie oznacza to jednak, że nic się nie zmieniło.

Po pierwsze, możliwe jest sprecyzowanie, jaka jest relacja między przypisaniem a upoważnieniem organu do przeprowadzenia określonego postępowania ${ }^{162}$. Wydaje się, że tu powiązania przebiegają w następujący sposób:

\section{1. postępowanie $\leftarrow$ organ}

W tym przypadku, organowi nadana jest kompetencja do przeprowadzenia potencjalnego postępowania.

158 Ibidem, s. 295.

159 Ibidem, s. 296.

160 Ibidem, s. 297.

161 C. Heidemann, Der Begriff der..., s. 31.

162 Zob. RR2, s. 244. 


\section{2. organ $\leftarrow$ postępowanie}

Tutaj przeprowadzone postępowanie jest przypisane organowi. Zatem, można obrazowo powiedzieć, że upoważnienie organu państwowego i przypisanie to dwie strony tego samego medalu. Wydaje się, że analogicznie sytuacja wygląda w odniesieniu do osób prawnych.

Po drugie, w jaki sposób Kelsen radzi sobie z połączeniem statycznych aspektów z dynamicznymi. Kelsen pisze:

Statyczna i dynamiczna zasada są zespolone w jednym systemie, kiedy hipotetyczna norma podstawowa upoważnia organ do tworzenia prawa i kiedy ten lub przez niego ustanowiony organ ustanawia nie tylko normy, w których inne organy prawodawcze są delegowane, ale również takie, w których określone zachowanie podmiotu [...] jest nakazane i z którego [...] dalsze normy mogą być dedukowane na mocy logicznych operacji ${ }^{163}$.

Wydaje się, że ten cytat nie wyjaśnia za wiele. Wiadomo, że zasada dynamiczna jest $\mathrm{z}$ tego punktu widzenia pierwotna. Najpierw pojawiły się normy upoważniające, bo w końcu mogło dojść do wydania normy wyposażonej w sankcję. Wiadomo również, że ze statycznego punktu widzenia te wszystkie normy w jednym łańcuchu składają się na pełną normę prawną, której ostatnim elementem jest przymus ${ }^{164}$.

Na temat przypisania krytycznie wypowiada się Heidemann. Zwraca uwagę, że przypisanie nie jest konstrukcją konieczną w czystej teorii prawa, a jedynie spełnia funkcję pomocniczą. Dzięki niemu określonemu kręgowi adresatów przyporządkowane są takie, a nie inne prawa i obowiązki. Przypisanie, według Heidemanna, w postaci przedstawionej przez Kelsena prowadzi do absurdalnego wniosku, że wszystkie zachowania mające znaczenie prawne muszą być przypisane państwu. Przypisanie jest jedynie wyrazem przyporządkowania określonego stanu faktycznego osobie, przy czym kryteria tego przyporządkowania nie są ze sobą powiązane. Heidemann konkluduje, że przypisanie jest prawnie irrelewantne, ponieważ w żaden sposób nie determinuje, czy dany akt został przypisany osobie. Konstrukcja ta natomiast jedynie stanowi niepotrzebną komplikację ${ }^{165}$. Wydaje się, że za podsumowanie może służyć pytanie: skoro sam Kelsen twierdzi, że przypisanie jest „konstrukcją pomocniczą”, „fikcją”, to po co w ogóle ją utrzymał? Skoro można te same problemy ując inaczej, nie angażując w to pojęcia osoby i przypisania, to dlaczego tego nie uczynił? Podczas lektury rozdziałów dotyczących osób i przypisania bynajmniej nie odnosi się wrażenia, że pojęcia te pomagają w osiągnięciu większej klarowności wywodu. Raczej odnosi się wrażenie, że Kelsen nie był w stanie przekroczyć rubikonu i z nich zrezygnować.

\footnotetext{
${ }^{163}$ Ibidem, s. 200.

164 Ibidem, s. 240.

165 C. Heidemann, Der Begriff der..., s. 32.
} 
Stąd wybrał rozwiązanie kompromisowe, posługując się terminologią zaczerpniętą z tradycji pozytywistycznej, a w co drugim zdaniu powtarzał, że to fikcja o charakterze pomocniczym.

\subsection{Zarachowanie a przypisanie}

Wydaje się, że większość spostrzeżeń dotyczących relacji zarachowania i przypisania, poczynionych w poprzednim rozdziale, jest aktualna, jednak warto zwrócić uwagę na ciekawe spostrzeżenie Heidemanna na temat różnicy między zarachowaniem peryferyjnym a przypisaniem z punktu widzenia upoważnienia. Zwraca on uwagę, że pozornie mogłoby się wydawać, że jest to znakomity punkt łączący obie koncepcje z tego względu, że z jednej strony zachowanie jest przypisane określonej osobie, gdy jest do tego upoważniona, z drugiej, akt przymusu (związany z zarachowaniem peryferyjnym) dochodzi do skutku, gdy organ jest upoważniony do określonego działania. Można byłoby zatem wysnuć wniosek, że sądy dotyczące zarachowania i przypisania są identyczne. Nic bardziej błędnego, twierdzi Heidemann, ponieważ sądy dotyczące zarachowania odnoszą się do wewnętrznej struktury prawa, podczas gdy przypisanie pełni rolę pomocniczą dla ustalenia, czy określona grupa regulacji prawnych spełnia kryteria bycia osobą. Heidemann przyznaje jednak, że właściwym ujęciem jest to wskazujące na dwojaką rolę upoważnienia: $\mathrm{z}$ jednej strony akt przymusu stoi w relacji do warunku wyrażonego w normie, a z drugiej jest przypisany państwu ${ }^{166}$.

Z kolei według Lippolda podstawowa różnica między zarachowaniem a przypisaniem może być ujmowana $\mathrm{z}$ dynamicznego i statycznego punktu widzenia. W dynamicznym spojrzeniu zarachowanie konstytuuje obowiązki, podczas gdy przypisanie osoby, którym następnie owe obowiązki są zarachowywane. Przypisanie jest zatem w dynamicznej strukturze warunkiem zarachowania, ponieważ najpierw powstaje upoważnienie. Natomiast ze statycznego punktu widzenia na pierwszym planie pojawia się zarachowanie, nakładając obowiązek określonego zachowania. Przypisanie jest tylko w tle, umożliwiając powiązanie zachowania ludzkiego osobie w znaczeniu prawnym ${ }^{167}$.

\subsection{Podsumowanie}

Zarachowanie peryferyjne, według Heidemanna, jest przystosowane do koncepcji mającej u swego podłoża filozofię neokantowską, formułującą prawo jako związki pomiędzy sądami. Nie da się jej jednak zintegrować z dynamiczną

${ }^{166}$ C. Heidemann, Der Begriff der..., s. 31, przyp. 61.

167 R. Lippold, Reine Rechtslehre..., s. 116-117. 
strukturą prawa. Poza tym nie wszystkie postaci norm zawierają w sobie zarachowanie. Heidemann pisze:

Kelsen z jednej strony chce usprawiedliwić użycie powszechnej prawniczej terminologii, $\mathrm{z}$ drugiej owa terminologia $\mathrm{w}$ ramach jego teorii jest zupełnie nieadekwatna. Zadowalające wyjaśnienie takich pojęć, jak: „osoba”, ,przypisanie”, „prawo (subiektywne)”, „obowiązek” jest w jej ramach jako formalnej teorii niezbędnych warunków poznania prawnego [...] niemożliwe ${ }^{168}$.

Heidemann stawia pytanie, czy w konstrukcji zarachowania i przypisania jest coś do uratowania i stwierdza, że na pierwszy rzut oka nie dostrzega się niczego takiego. Zauważa przy tym, że prawdopodobnie Kelsen jego zarzut o nieadekwatności wymienionych pojęć uznałby za argument za tym, czego próbował dokonać, to znaczy: redukcję wszelkich pojęć prawnych do normy i jego krytykę pojęć prawnych, z których rzekomo nie da się zrezygnować. Poza tym, zauważa Heidemann, zarachowanie jako element odnoszący się do struktury prawnej ma sens, nawet gdy zrezygnuje się z wątków neokantowskich, gdyż spełnia ważną rolę w budowaniu obiektywnej koncepcji norm, nawet jeśli nie jest tożsame z powinnością. Ostatecznie nie da się pojęcia zarachowania wyeliminować z teorii Kelsena. Jego rola sprowadza się do naukowego narzędzia mającego określić bezpośrednie cele norm generalnych ${ }^{169}$. Wydaje się, że należy przyznać Heidemannowi rację. Czysta teoria prawa $\mathrm{w}$ fazie realistycznej, z punktu widzenia zarachowania, prawie w każdym punkcie zawiera wyraźne niespójności. Sprawia przez to wrażenie fazy przejściowej, jest ,pomiędzy”. Już nie jest to neokantyzm, ale jeszcze nie filozofia analityczna, której niewyraźne echa jednak już słychać.

168 C. Heidemann, Der Begriff der..., s. 32.

169 Ibidem, s. 23-24. 


\section{Rozdział VII Zarachowanie w fazie językowo-analitycznej}

\subsection{Charakterystyka fazy językowo-analitycznej}

Ostatnia faza w twórczości Kelsena jest zdecydowanym odejściem od wielu podstawowych postulatów czystej teorii prawa. Do tego jest to próba zbudowania teorii odnoszącej się do wszelkich rodzajów norm, a nie tylko norm prawnych. Weinberger definiuje ostatnią fazę w następujący sposób:

Czysta teoria prawa jest analityczną teorią systemu norm, który [...] jest skierowany, w pierwszej kolejności, na racjonalne relacje zawarte w systemie prawa; to znaczy: chodzi o naukę, której istnienie jest uwarunkowane przez specyficzne struktury myślenia i racjonalne operacje w zakresie systemu norm ${ }^{1}$.

Nazwa tego okresu, zaproponowana przez Heidemanna: faza analityczno-językowa, wydaje się bardzo adekwatna. Jej językowo-analityczny charakter jest rezultatem sięgnięcia przez Kelsena do dwóch spośród trzech nurtów filozofii analitycznej: semantycznego, syntaktycznego i pragmatycznego. Kelsen oparł swoje koncepcje na semantyce poprzez przekonanie, że jedyną droga poznania jest filozoficzna analiza języka. Natomiast odwołał się do pragmatyki, ustalając ją kryterium różnicującym (wcześniej tę role pełniły kategorie)2 ${ }^{2}$.

Nazwa ta akcentuje również zmianę w poglądach Kelsena, czyli odejście od neokantowskich założeń na rzecz filozofii analitycznej³. Owa zmiana nie była jednak czymś zaskakującym. Jak wcześniej wykazałam, jej zapowiedź jest już widoczna w poprzedniej fazie, w szczególności w wydaniu II Czystej teorii prawa. Warto przy tym dodać, że sama Ogólna teoria norm w pewnej części składa się ze skorygowanych artykułów opublikowanych po roku 19604. Ewald Wiederin wskazuje nawet dzień, który stał się punktem zwrotnym w poglądach Kelsena.

${ }^{1}$ O. Weinberger, Normtheorie als Grundlage der Jurisprudenz und Ethik, Schriften zur Rechtstheorie, Duncker Humblot, Berlin 1981, s. 24.

2 C. Heidemann, Die Norm als Tatsache. Zur Normentheorie Hans Kelsen, Nomos Verlagsgesellschaft, Baden-Baden 1997, s. 164.

${ }^{3}$ M. Zalewska, Zapomniana monografia „Ogólna teoria norm” Hansa Kelsena, [w:] O. Nawrot, S. Sykuna, J. Zajadło (red.), Konwergencja czy dywergencja kultur i systemów prawnych?, Wydawnictwo C.H. Beck, Warszawa 2012, s. 354,

${ }^{4}$ Ibidem, s. 349. 
Jest to 6 marca 1959 r., kiedy to Kelsen w liście do Urlicha Kluga zdradza, że po lekturze „logiki prawniczej” (juristische Logik) nabrał wątpliwości co do kwestii zastosowania logiki do norm. Wiederin dodaje, że wtedy wydanie II Czystej teorii prawa było już gotowe i zamiast utwierdzić Kelsena w słuszności jego koncepcji, wywołało nowe wątpliwości ${ }^{5}$. Jednak Kelsen, który zmarł w 1973 r., nie zdążył ukończyć swojej nowej książki. Pozostawił jedynie manuskrypt, a nie będąc pewnym założeń swojej nieukończonej teorii, zalecił ocenę zasadności tej publikacji. Uczniowie Kelsena nie mieli wątpliwości co do wartości tego dzieła i w roku 1979 Ogólna teoria norm ukazała się nakładem Instytutu Hansa Kelsena.

Hartney trafnie opisał systematykę książki, zauważając, że:

Ogólna teoria norm składa się z kilku niezależnych od siebie części, które równie dobrze mogłyby zostać opublikowane oddzielnie, zresztą wiele z nich zostało wcześniej opublikowanych w postaci artykułów 6 .

Książka jest zatem podzielona na dwie części: pierwsza z nich to poszczególne rozdziały, natomiast druga to kolejne przypisy zawierające komentarze odnoszące się do myśli filozofów, teoretyków prawa i logików. Taki podział nadał przypisom należną im rangę, ponieważ stanowią one nieomal połowę objętości książki i - przynajmniej niektóre - podnoszą jej wartość merytoryczną ${ }^{7}$. Wiele z nich zaskakuje twórczym i kompetentnym podejściem do omawianego tematu, inne natomiast rozczarowują, najczęściej ze względu na to, że odnoszą się do odkryć (szczególnie w dziedzinie logiki) z początków XX w. ${ }^{8}$ We współczesnej dyskusji nad poglądami Kelsena często pojawia się pytanie: „dlaczego Kelsen zmienił swoje poglądy”. Jednak, moim zdaniem, powinno ono raczej brzmieć: ,czy Kelsen nie zmienił swoich poglądów zbyt późno"9. W końcu przełom w szeroko rozumianej logice dokonał się pod koniec XIX w. za sprawą m.in. Gottloba Fregego, a jego pierwszą pracę i ostatnią Kelsena dzieli sto lat. Jednak, po pierwsze, od samego początku naukowej kariery Kelsena widać zbieżność jego myśli z poglądami reprezentantów Koła Wiedeńskiego, a po drugie, jak wskazuje Kazimierz Opałek, do końca lat pięćdziesiątych (kiedy pojawiły się prace Perelmana i von Wrighta) logiczno-językowy aspekt teorii prawa nie był szczególnie rozwinięty. Sam Kelsen był zapoznany z najnowszymi publikacjami mniej więcej do roku 1965, by potem jedynie opracowywać swoją nową teorię ${ }^{10}$. Owe starania Opałek podsumowuje następująco:

${ }^{5}$ E. Wiederin, Das Spätwerk Kelsens, Schriftenreihe des Hans Kelsen-Institutes, Wien 2009, s. 356.

${ }^{6}$ Ibidem, s. XI.

7 Szczegółowo wylicza je M. Hartney, Introduction: The Final Form of the Pure Theory of Law, [w:] H. Kelsen, General Theory of Norms, trans. M. Hartney, Clarendon Press, Oxford 1991, s. XIII.

8 Ibidem, s. XIV-XV.

${ }^{9}$ M. Zalewska, Zapomniana monografia..., s. 354.

${ }^{10}$ K. Opałek, Überlegungen zu Hans Kelsens ,, Allgemeine Theorie der Normen, Schriftenreihe des Hans Kelsen-Instituts, Wien 1980, s. 8, 13-14. 
Kelsen w swoich późnych latach dokonał próby godnej najwyższej aprobaty: ujednolicenia nowej literatury filozofii analitycznej, teorii norm, metaetyki, logiki norm i logiki deontycznej ${ }^{11}$.

Opałek zauważa, że Kelsen opanował niezbędną literaturę w dostatecznym stopniu, aby sformułować swoją teorię i jej bronić12. Moim zdaniem, zwrot Kelsena ku filozofii analitycznej jest słuszną decyzją, ponieważ zgodną z duchem czasu $^{13}$. Wprawdzie ta koncepcja wydaje się mniej twórcza w porównaniu z klasyczną czystą teorią prawa i zawierającą znacznie więcej luk i niedociągnięć. Nie należy jednak zapominać, że Kelsen tej książki nie ukończył14, a istnieje istotna różnica między pracami ukończonymi a „prawie ukończonymi”'15.

Co zatem konkretnie zmieniło się w ostatniej fazie? Przede wszystkim teza, że nie da się zastosować logiki do norm. Jak wskazuje van Eikema Hommes, porzucenie koherencji między normą prawną i logicznymi zasadami musiało prowadzić do porzucenia logiczno-transcendentalnej koncepcji poznania, w tym zarachowania ${ }^{16}$. Heidemann twierdzi, że, w stosunku do trzeciej fazy Kelsen utrzymuje tezę, która była tam nowością - o rozdziale płaszczyzny poznawczej i płaszczyzny obiektów, natomiast sama teza, że nauka prawa konstytuuje i nadaje sens systemowi, została ostatecznie porzucona ${ }^{17}$. Poza tym, według Wiederina, Kelsen zmienił założenia swojej teorii w trzech aspektach: po pierwsze, wprowadził językowo-analityczne uzasadnienie dualizmu bytu i powinności; po drugie, umiejscowił normę w zakresie specyficznie pojętych stanów faktycznych; po trzecie, Kelsen już nie mówi o teorii prawa, tylko o teorii norm. Ogólna teoria norm dotyczy zatem wszystkich norm, nie tylko prawnych. Jednak w rzeczywistości Kelsen zajmuje się nieomal wyłącznie normami prawnymi i moralnymi, tym pierwszym poświęcając oczywiście najwięcej uwagi.

$\mathrm{W}$ tej fazie zmienia się ponadto definicja samej normy oraz normy podstawowej, którą Kelsen uznaje za fikcję, czyli twierdzi, że należy ją założyć wbrew faktom, co powoduje (według Paulsona), że należy tak postępować, jakby materiał prawny miał charakter normatywny. W rezultacie wzmocnienia tezy redukcyjnej i osłabienia tezy normatywnej ta druga nie daje się obronić18. Jabloner wskazuje, że wprowadzenie teorii imperatywu bardzo wzmocniło pozytywistyczny charakter czystej teorii prawa ${ }^{19}$. Tym samym Kelsen już tak radykalnie

1 Ibidem, s.15.

12 Ibidem.

13 M. Zalewska, Zapomniana monografia..., s. 355.

${ }_{14}$ M. Hartney Introduction..., s. IX-XX.

15 M. Zalewska, Zapomniana monografia..., s. 355.

${ }^{16}$ H.J van Eikema Hommes, The Development of Hans Kelsen's Concept of Legal Norm, „Rechtstheorie” 1984, Bd. 5, s. 177.

17 C. Heidemann, Die Norm als..., s. 161.

18 S.L. Paulson, Kelsen's Legal Theory: the Final Round, „Oxford Journal of Legal Studies” 1992, vol. 12, s. 269-270.

${ }^{19}$ C. Jabloner, Kein Imperativ ohne Imperator. Anmerkungen zu einer These Kelsens, Schriftenreihe des Hans Kelsen-Instituts, Wien 1988, s. 77. 
nie odrzuca tezy redukcyjnej. W ATN Kelsen poświęca bardzo mało uwagi zarachowaniu. To pojęcie pojawia się w jednym krótkim rozdziale. Natomiast w ogóle nie jest wspomniane przypisanie. Zatem zadaniem niniejszego rozdziału będzie przeanalizowanie kluczowych dla zarachowania pojęć: dualizmu bytu i powinności oraz normy prawnej i próba odpowiedzi na pytanie, czy zarachowanie peryferyjne i centralne mają rację bytu w nowej ostatecznej rewizji czystej teorii prawa, a jeśli tak, to, jaki mają charakter i jakie pełnią funkcje.

\subsection{Dualizm bytu i powinności}

\subsubsection{Dualizm bytu i powinności na płaszczyźnie językowej}

W niniejszej fazie Kelsen swoje rozważania na temat bytu i powinności rozpoczyna od rozróżnienia dwóch rodzajów przykładowych wypowiedzi. W pierwszej $\mathrm{z}$ nich określony podmiot coś powinien, natomiast $\mathrm{w}$ drugiej, określony podmiot coś chce. Kelsen zwraca uwagę, że o ile pierwsza odnosi się do świata powinności, o tyle druga do świata bytu. Byt i powinność są zatem dwoma różnymi nośnikami sensu ${ }^{20}$. Widać tu wyraźnie, że Kelsen rozpatruje byt i powinność na nowej, wcześniej nieuwzględnianej płaszczyźnie: językowej. Tak jak poprzednio są to pojęcia formalne, nie zawierające w sobie żadnej zdeterminowanej treści i nie są od siebie uzależnione. Kelsen wskazuje, że zarówno zdanie: „ludzie powinni umierać”, jak i zdanie: „ludzie nie powinni umierać”, są zdaniami sensownymi, ale tylko drugie z nich ma swój odpowiednik na płaszczyźnie bytu ${ }^{21}$.

Heidemann wskazując, że to ujęcie nie zostało przez Kelsena jasno sformułowane i nazbyt często zależy od kontekstu, podejmuje następującą próbę jego rekonstrukcji: Kelsen neguje, że w przypadku bytu i powinności chodzi o określone płaszczyzny myślenia ${ }^{22}$. Teraz byt i powinność jawią się jako posiadające charakter językowy ${ }^{23}$ i są kategoriami, ale to określenie pozbawione jest charakteru transcendentalnego. Tak jak w RR2, są to niedefiniowalne podstawowe pojęcia, których uzasadnienie leży w logice ${ }^{24}$. Moim zdaniem, w ten sposób Kelsen oparł swoją teorię na aksjomatach, którymi są byt i powinność. Byt i powinność odnoszą się do znaczeń wyrażeń językowych i są trybami poszczególnych typów zdań. Byt jest trybem zdań twierdzących, natomiast powinność zdań normatywnych, w związku z czym, w każdym zdaniu można wyróżnić jego sens oraz treść. O ile sensem zdań oznajmujących jest to, że coś miało miejsce, coś się zdarzyło, to norm, że coś zdarzyć się powinno. Natomiast treścią zdania jest to, co miało

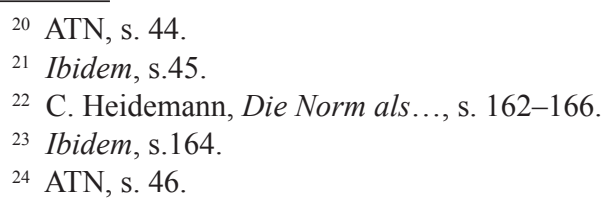


miejsce, zaś norm, co wydarzyć się powinno ${ }^{25}$. Wynikałoby z tego, że sens odnosi się poziomu językowego, natomiast treść do poziomu obiektów. Kelsen zauważa przy tym, że idealna powinność nie może zawierać w sobie żadnych elementów bytu. Oznacza to, że norma nie jest zmodyfikowanym zdaniem oznajmującym ani nie zawiera w sobie zdania oznajmującego, tylko, że oba rodzaje zdań zawierają w sobie substrat modalnie indyferentny, który jest częścią wspólną dla normy i zdania opisowego ${ }^{26}$. Na przykład w normie:

„Żołnierz powinien wykonywać swoją służbę sumiennie”

i w zdaniu:

„Żołnierz wykonuje swoją służbę sumiennie”,

modalnie indyferentnym substratem będzie: „wykonuje swoją służbę sumiennie”. Nie ma on wartości logicznej ${ }^{27}$ i, jak wskazuje Heidemann, staje się w ten sposób „trzecim wymiarem” obok bytu i powinności ${ }^{28}$. Takie ujęcie rodzi problem, ponieważ z ontologicznego punktu widzenia byt i powinność odzwierciedlają odpowiednio obiekt realny i idealny. Jaki zatem charakter ma substrat modalnie indyferentny? Opałek zwraca uwagę, że Kelsen próbuje rozwiązać ten problem, wskazując, że akt woli powiązany jest z aktem myślowym, z tym że określone zachowanie nie zostaje pomyślane jako osadzone w bycie, lecz jako substrat modalnie indyferentny.

Opałek krytykuje takie ujęcie, ponieważ jednym z podstawowych rozróżnień w ATN jest właśnie rozróżnienie na akty woli i akty myślowe. Są one sobie przeciwstawiane i nie ma tu zatem mowy o modalnie indyferentnym myśleniu. Podobnego zdania jest Wróblewski, stwierdzając, że z punktu widzenia kelsenowskiej ontologii wszystko istnieje w którejś z modalności, zatem trudno znaleźć tu miejsce dla czegoś, co jest modalnie indyferentne ${ }^{29}$. Kelsen próbuje i to wybronić, wskazując, że od wiedzy należy odróżnić mniemanie, które polega na tym, że „ktoś, kto wydaje rozkaz, coś mniema”, czyli musi wiedzieć, czego chce. Opałek zauważa, że w ten sposób Kelsen jedynie zastąpił substrat modalnie indyferentny mniemaniem ${ }^{30}$. O wiele lepiej ocenia tę konstrukcję Achtenberg, podkreślając, że substrat modalnie indyferentny, mimo że tworzy most między bytem i powinnością, nie stanowi naruszenia podstaw czystej teorii prawa. Należy

${ }^{25}$ C. Heidemann, Die Norm als..., s. 166.

${ }^{26}$ ATN, s. 46.

${ }^{27}$ Ibidem, s. 46-47; M. Hartney, Introduction..., s. XIX.

${ }^{28}$ C. Heidemann, Die Norm als..., s. 179.

29 J. Wróblewski, The Is - Ought Dichotomy, „Revue Internationale de Philosophie” 1981, vol. 138, s. 515.

${ }^{30}$ K. Opałek, Überlegungen..., s. 27; ATN, s. 25. 
go raczej traktować jako powiązanie pozwalające na zmianę jednej modalności w drugą ${ }^{31}$.

Wprowadzenie płaszczyzny językowej nie oznacza, że zanikła płaszczyzna ontologiczna, na której również są one rozpatrywane. Byt w tym ujęciu sprowadza się do faktów empirycznych, podczas gdy powinność do norm ${ }^{32}$. Zatem, jak zauważa Heidemann, Kelsen miesza płaszczyznę językową z ontologiczną. Rodzi to dwojakiego rodzaju wątpliwości; po pierwsze, czy Kelsenowi na pewno chodzi o językowy wymiar dualizmu bytu i powinności ${ }^{33}$; a jeśli tak, to po drugie, czy istnieją one na gruncie semantyki i znaczenia, czy pragmatyki, odnosząc się - do sposobu funkcjonowania danego wyrażenia w określonym kontekście ${ }^{34}$.

\subsubsection{Funkcje powinności i jej podziały}

Według Weinbergera, Kelsen używa określenia „powinność” w następujących znaczeniach. Po pierwsze wtedy, gdy określone zachowanie jest nakazane lub zakazane. Oznacza to, że powinność jest ich zawartością. Po drugie, powinność jest postrzegana jako wspólny łącznik zawartości normatywnej wszystkich norm. Spełnia on różnorakie funkcje, takie jak nakaz, dozwolenie i upoważnienie. Wydaje się, że może tu chodzić o powinność w funkcji zarachowania. Po trzecie, dochodzi nowa funkcja - derogacja, przy czym Weinberger wskazuje, że dyskusyjne jest, czy można jej przyporządkować normatywny operator ${ }^{35}$. Powiązania między poszczególnymi funkcjami powinności ściśle wiążą się z rodzajami $n^{n}{ }^{36}$. Problem ten zostanie omówiony szerzej w kontekście zarachowania. Weinberger wskazuje na trudność takiego ujęcia, polegającą na tym, że jeśli normę zdefiniuje się jako imperatyw, to dozwolenie nie może być normą ${ }^{37}$. Weinberger proponuje rozwiązanie tego problemu poprzez przyjęcie, że powinność odnosi się tylko do nakazu i zakazu, natomiast wszelkie odmiany dozwolenia przyporządkować modalności możności (Dürfen). Zabieg ten dotyczy zarówno norm prawnych, jak i zdań prawnych ${ }^{38}$.

Odnośnie do podziału na obiektywną i subiektywną powinność, Jabloner wskazuje, że zmieniło się niewiele. Teraz większy nacisk położony jest na powinność w sensie subiektywnym. Powinność subiektywna jest teraz sensem rozkazów, będących aktami woli bezpośrednio skierowanymi na zachowanie innych ${ }^{39}$.

${ }^{31}$ N. Achterberg, Autonome Determinante und modal indifferentes Substrat, ,,Rechtstheorie“ 1984, Bd. 5, s. 451.

\footnotetext{
${ }^{32}$ C. Heidemann, Die Norm als..., s. 166.

33 Ibidem.

${ }^{34}$ Ibidem, s. 167.

${ }^{35}$ O. Weinberger, Normtheorie als..., s. 50.

36 Ibidem.

37 Ibidem, s. 51.

38 Ibidem.

39 C. Jabloner, Kein Imperativ..., s. 76.
} 
Z kolei podział na powinność preskryptywną i deskryptywną wprawdzie pozostał bez zmian, ale umieszczenie go w kontekście najnowszej teorii budzi wątpliwości, na której z płaszczyzn został dokonany: semantycznej czy pragmatycznej ${ }^{40}$.

\subsection{Norma prawna}

Kelsen tworzy woluntarystyczną teorię norm, w której widoczne są wątki empiryczne, zaś neokantyzm praktycznie zanikł. W ATN ponownie pojawia się definicja normy jako sensu aktu woli, który jest skierowany na określone, powinne zachowanie innej osoby ${ }^{41}$. W tym samym okresie można znaleźć podobne definicje, na przykład normy jako ,specyficznego znaczenia aktu woli skierowanego na określone ludzkie zachowanie"42. Jak wskazuje Heidemann, Kelsen wprawdzie ową definicję opatruje wyjaśnieniami, dzięki czemu wiele wątpliwości powstałych w RR2 da się wyeliminować, jednak te wyjaśnienia jednocześnie rodzą pole do nowych spekulacji. W rezultacie powstało kilka koncepcji dotyczących jej znaczenia. Według Heidemanna, niektórzy twierdzą, że Kelsen powrócił do swojej teorii aktów intencjonalnych, gdzie norma miałaby być idealnym nośnikiem sensu. Inni z kolei odwołują się do analitycznego rozumienia normy i kładą nacisk na to, że norma jest znaczeniem określonej kategorii zdań. Ponadto, doktryna wskazuje również na pragmatyczną funkcję normy, która jest jednym z typów aktów mowy. Inni odwołują się do realistyczno-ontologicznej koncepcji normy jako analogicznej do empirycznego obiektu ${ }^{43}$. Heidemann wskazuje, że w pierwszych trzech przypadkach Kelsen rozpatruje normę jako wypowiedź, natomiast w czwartym norma jest ujęta jako przeciwstawienie faktu ${ }^{44}$.

\subsubsection{Definicja normy prawnej}

Aby zrozumieć definicję normy prawnej, należy najpierw odwołać się do wprowadzonego przez Kelsena podziału aktów umysłowych na akty myślowe i akty woli. Znaczeniem (zawartością) aktu myślowego jest twierdzenie, że coś ma miejsce; natomiast znaczeniem aktu woli zorientowanego na zachowanie innych jest norma. Język pełni zatem funkcję upublicznienia znaczenia aktów

${ }^{40}$ C. Heidemann, Die Norm als..., s. 168.

${ }^{41}$ ATN, s. 3.

${ }^{42}$ H. Kelsen, On the Pure Theory of Law, „Israel Law Review” 1966, vol. 1, s. 1; por. z Kelsenowską definicją normy wskazaną przez Opałka i Wróblewskiego: jako sensu opartego na upoważnieniu aktu rozkazu” (K. Opałek, J. Wróblewski, Prawo: metodologia filozofia, teoria prawa, PWN, Warszawa 1991, s. 181).

${ }^{43}$ C. Heidemann, Die Norm als..., s. 174.

${ }^{44}$ Ibidem. 
umysłowych. Jak wskazuje Hartney, widać tu silną korelację tego, co mentalne z tym, co językowe ${ }^{45}$. Norma, jak twierdzi Kelsen, jest: ,produktem aktu mowy, w którym wyartykułowany zostaje sens aktu woli" ${ }^{46}$. Znaczenie jest definiowane przez Kelsena jako zdanie, formułujące zawartość aktu umysłowego (czyli są to odpowiednio konkretne zdania lub normy) ${ }^{47}$. Norma prawna, poza tym, że może być zawartością znaczenia aktu intencjonalnego (skierowanego na wolę), jest również znaczeniem określonego typu zdania, zdania normatywnego. Posiadanie znaczenia dla Kelsena jest cechą znaku lub grupy znaków, w szczególności wyrazów, które odnoszą się do jakiegoś obiektu" ${ }^{48}$. Jednak Opałek i Wróblewski wskazują, że Kelsen, mówiąc o sensie, nie miał na myśli aspektu semantycznego, lecz chodziło mu o ,sens przedmiotów niejęzykowych”, jak się je rozumie w filozofii kultury.

Autorzy jednocześnie przyznają, że w tym zakresie brak u Kelsena konsekwencji ${ }^{49}$ Opałek dodaje, że znaczenie nie zawsze jest ujmowane przez niego (w nawiązaniu do Fregego i Ryle'a) jako wyrażenie językowe. Często odnosi się do empirycznych aktów woli i ma neokantowskie konotacje, niosąc ze sobą ponadempiryczny sens o powinnym charakterze faktów empirycznych. Powoduje to napięcie między „starym” i „nowym” rozumieniem sensu. W konsekwencji, Kelsen, co do zasady, unika rozróżnienia na sens i znaczenie, ograniczając się do rozumienia „sensu” jako denotacji czy ekstensji ${ }^{50}$.

Hartney zwraca uwagę na ewolucję, którą przeszło to pojęcie. W RR1 znaczeniem jakiegoś aktu była interpretacja nadana na mocy powszechnej praktyki, dzięki czemu pozbawienie kogoś życia mogło być uznane w jednym przypadku za przestępstwo zabójstwa, a w innym za egzekucję. W ATN znaczenie już nie jest interpretacją aktu, tylko jego mentalną zawartością. Do tego zarówno twierdzenia, jak i normy są znaczeniem, podczas gdy w drugiej fazie znaczenie wchodziło w grę tylko w przypadku norm. Hartney konkluduje, że różnica między aktem i znaczeniem nie sprowadza się do relacji fakt-interpretacja, tylko do relacji akt mentalny-jego zawartość $^{51}$. Heidemann zauważa, że znaczenie psychologicznego aktu jest jego obiektem i jednocześnie idealną rzeczywistością, która w akcie przybiera realne kształty. Pomiędzy aktem i znaczeniem powstaje w ten sposób kategorialna różnica powodująca, że istnienie jednego jest oddzielone od istnienia drugiego ${ }^{52}$.

Jak wskazuje Bernard S. Jackson, istnieją dwie formy znaczenia normy prawnej: pierwotne znaczenie subiektywne oraz znaczenie obiektywne, które nie może

\footnotetext{
${ }^{45}$ M. Hartney Introduction..., s. XXXVIII.

${ }^{46}$ ATN, s. 131.

${ }^{47}$ M. Hartney, Introduction..., s. XXXVIII.

${ }^{48}$ C. Heidemann, Die Norm als..., s. 177.

${ }^{49}$ K. Opałek, J. Wróblewski, Prawo: metodologia ..., s. 181.

${ }^{50}$ K. Opałek, Überlegungen..., s. 22; zob. ATN, s. 132.

${ }^{51}$ M. Hartney, Introduction ..., s. XXXVIII.

${ }^{52}$ C. Heidemann, Die Norm als..., s. 175.
} 
powstać bez znaczenia subiektywnego. Obiektywność nadaje tu domniemanie normy podstawowej, która w tej fazie została przez Kelsena uznana już nie za hipotetyczne, lecz za fikcyjne założenie ${ }^{53}$.

Warto zauważyć, że Kelsen w swoich rozważaniach nawiązuje również do Fregego. Odwołując się do jego przykładu gwiazdy porannej i gwiazdy wieczornej jako rozróżnienia znaczenia i nominatu ${ }^{54}$, stwierdza, że norma prawna może mieć wiele znaczeńn ${ }^{55}$.Od podziału na znaczenie i nominat należy również odróżnić relację znaczenia do treści. Akt myślowy posiada swój sens i swoją treść. I tak, sensem aktu myślowego jest to, czy coś ma miejsce lub jest prawdą. Natomiast treścią jest to, co ma miejsce lub jest prawdą ${ }^{56}$. Znaczenie aktu woli jest skierowane na czyjeś określone powinne zachowanie, podczas gdy treść dotyczy samego zachowania (jakie to ma być zachowanie) i jest związane $\mathrm{z}$ aktem myślowym, zwanym substratem modalnie indyferentnym ${ }^{57}$.

Drugie kluczowe pojęcie kelsenowskiej definicji normy - „wola” - jest rozumiana przez Kelsena w znaczeniu realnym, fizycznym ${ }^{58}$. Jabloner wskazuje, że takie ujęcie nie do końca wyjaśnia, na czym owa wola miałaby polegać i jak ją rozpoznać. Kelsen wydaje się wspomagać psychologiczno-filozoficznymi koncepcjami przełomu wieków ${ }^{59}$ i tym samym rezygnuje z pojęcia osoby jako wytworu prawa na rzecz psychologicznego pojęcia „człowiek”60. Opałek przy tym wskazuje, że w pokrewnej literaturze zamiast „pojęcia aktu woli” używa się raczej sformułowania „decyzja” albo „performatyw”61. Wola wiąże się z powinnością, zaś to powiązanie jest uzasadniane przez Kelsena w następujący sposób: można mieć wolę, by coś miało miejsce w odniesieniu do własnej osoby lub kogoś innego. Jeśli wola dotyczy nas samych i tylko od nas zależy (na przykład wola podniesienia ręki), to wówczas można powiedzieć, że chce się, aby coś się wydarzyło $i$ to się wydarzy. Gdy jednak wola jest skierowana wobec osoby trzeciej, wówczas można jedynie powiedzieć: „chcę, aby osoba trzecia miała powinność zachowywania się w określony sposób ${ }^{62}$ ". Znaczeniem aktu woli jest zatem powinność czyjegoś określonego zachowania ${ }^{63}$. Zwrot ,powinna” wskazuje zatem na swego rodzaju niepewność, czy wola zostanie spełniona, osoba trzecia bowiem może zachować się zgodnie z naszą wolą, ale wcale nie musi ${ }^{64}$. Jak to znakomicie ujął

${ }_{53}$ B.S. Jackson, Semiotics and Legal Theory, Routledge Kegan \& Paul, London 1987, s. 225.

${ }_{54}$ Zob. G. Frege, Über Sinn und Bedeutung, http://sammelpunkt.philo.at:8080/419/1/24-1-94. TXT [4 VII 2010].

${ }_{55}$ ATN, s. 26.

${ }^{56}$ C. Heidemann, Die Norm als..., s. 176.

${ }^{57}$ Ibidem, s. 175.

${ }^{58}$ C. Jabloner, Kein Imperativ..., s. 79.

59 Ibidem.

${ }^{60}$ ATN, s. 23.

${ }^{61}$ K. Opałek, Überlegungen..., s. 22.

${ }^{62}$ „Ich will dass ein anderer sich in bestimmten Weise verhalten soll” (ATN, s. 25).

${ }_{63}$ ATN, s. 3; H. Kelsen, On the Pure..., s. 1.

${ }^{64}$ ATN, s. 25. 
Roberto J. Vernengo: „to, że coś powinno być, nie oznacza nic innego, jak tylko to, że A jest przez kogoś chciane"65. Właśnie w tym wyraża się stwierdzenie Kelsena, że powinność jest sensem aktu woli. Obiektem woli może być tylko ludzkie zachowanie, co jak wskazuje Heidemann, odróżnia wolę od życzenia ${ }^{66}$. Skierowanie woli na cudze zachowanie powoduje, że to zachowanie może być tylko powinne ze względu na to, że może zostać spełnione, a nie musi. Wola skierowana na własne zachowanie z powinnością raczej się nie wiąże, ponieważ dotyczy nas samych. Jeśli ma się wolę określonego własnego zachowania, to można ją urzeczywistnić. Wola skierowana na zachowanie innego zakłada dodatkowy czynnik - ta osoba musi jeszcze zechcieć naszą wolę urzeczywistnić. Wola taka nabiera cech obiektywnych, jeśli pochodzi od organu umocowanego przez państwo. Opałek zauważa, że w przeciwieństwie do wcześniejszych publikacji teraz Kelsen pisze o woli jako o realnym ludzkim akcie, skierowanym na zachowanie realnego człowieka ${ }^{67}$. Jak zatem widać, Kelsen odstąpił i tu od swoich radykalnych założeń czystości teorii prawa. Człowiek w tym ujęciu już nie jest sztuczną konstrukcją prawną, pewnym zbiorem praw i obowiązków, tylko realną jednostką ludzką.

Zatem norma jest ujmowana jako znaczenie aktu woli odpowiedniego organu, gdzie akt woli jest warunkiem obowiązywania normy prawnej ${ }^{68}$. Hartney zauważa, że takie zdefiniowanie normy prawnej posiada również swoje słabości. Jeśli normę zdefiniuje się jako sens aktu woli skierowanego na czyjeś zachowanie, to zanika różnica między bandytą rabującym w ciemnej uliczce a urzędem podatkowym. Oba podmioty wydają rozkaz, by zachować się w określony sposób ${ }^{69}$. Jak wskazuje Zirk-Sadowski, z tym problemem poradził sobie wyrafinowany pozytywizm Harta za pomocą rozróżnienia wewnętrznego i zewnętrznego aspektu reguły. Dopiero wewnętrzny aspekt reguły pozwala uchwycić różnicę między aktem przemocy i posłuszeństwem mu a przestrzeganiem prawa ${ }^{70}$.

\subsubsection{Podziały norm prawnych}

Pierwszy jest podział na normy indywidualne i generalne. Kelsen w swojej teorii uwzględnia oba rodzaje. Norma indywidualna to taka, w której powinne zachowanie jest konkretne, jednorazowe, skierowane do konkretnego adresata

${ }^{65}$ R.J. Vernengo, Das Modal Indifferente Substrat der Normen in der Allgemeine Theorie der Normen, „Rechtstheorie“ 1984, Bd. 5, s. 554.

${ }^{66}$ C. Heidemann, Die Norm als..., s. 175.

${ }^{67}$ K. Opałek, Überlegungen..., s. 22.

${ }^{68}$ F. Schreier, Rechtsnorm und Rechtssatz, Schriftenreihe des Hans Kelsen-Instituts, Wien 1982, s. 201; G. Kucsko-Stadlmayer, Rechtsnormbegriff und Arten der Rechtnormen, Schriften des Hans Kelsen-Instituts, Wien 1992, s. 35; Kelsen w ostatniej fazie odróżnia od normy prawnej zdanie prawne, które definiuje jako sens aktu myślowego (ibidem).

${ }^{69}$ M. Hartney Introduction..., s. XXXIX.

${ }^{70}$ M. Zirk-Sadowski, Prawo a uczestniczenie uczestniczenie $w$ kulturze, Wydawnictwo UŁ, Łódź 1998, s. 30-37. 
lub adresatów, natomiast generalna, gdy jakieś zachowanie, skierowane do adresatów określonych ogólnie, jest ustanowione jako powinne. Kelsen normę generalną nazywa regułą powinnościową (Soll-Regel $)^{71}$.

Drugi istotny jest podział na normy hipotetyczne i kategoryczne. Kelsen wskazuje, że różnica polega na tym, że te pierwsze są bezwarunkowe, a te drugie warunkowe. Rozróżnienie to dotyczy zarówno norm indywidualnych, jak i generalnych. Kelsen jednak zauważa, że jest to rozróżnienie pozorne, ponieważ wszystkie normy obowiązują warunkowo. Rozkazy po prostu milcząco zakładają warunki, pod jakimi obowiązują, na przykład rozkaz: „miłuj swoich wrogów” zakłada, że ma się wrogów. Ponadto, norma zawsze zawiera w sobie warunek, że obowiązuje ${ }^{72}$.

Trzeci z podziałów odnosi się do funkcji, jakie może spełniać norma prawna. Same funkcje normy nieznacznie się zmieniły od czasów RR2 i teraz norma ma cztery funkcje: nakazującą ${ }^{73}$, dozwalającą, upoważniającą i derogującą. Funkcje te są pochodną podziału powinności na nakazującą, zakazującą, dozwalającą, upoważniającą i derogującą.

Interesującą analizę funkcji, które mogą spełniać normy prawne, przedstawił Weinberger, rozpatrując kolejno nakaz, dozwolenie, derogację i upoważnienie. Normy spełniające funkcję nakazującą mają teraz dwóch adresatów: bezpośredniego (kompetentny organ) i pośredniego (osoba, na którą zostanie nałożona sankcja). Obydwaj adresaci mogą albo wypełnić dyspozycję normy, albo normę naruszyć. Z tego wynika, że odmiennie od trzeciej fazy teraz funkcja nakazująca dotyczy obu adresatów. Odnośnie do nakazów, Weinberger wskazuje na interesującą konsekwencję z punktu widzenia zarachowania. Jeśli przyjmie się definicję normy prawnej jako sensu aktu woli skierowanego na czyjeś zachowanie, to norma odnosi się do przykładowo zakazu kradzieży. Zatem tradycyjne kelsenowskie ujęcie normy prawnej jako normy pierwotnej jest sprzeczne z nową definicją ${ }^{74}$. Wydaje się, że należy przyznać Weinbergerowi słuszność. Jeśli norma prawna jest sensem aktu woli skierowanego na zachowanie innej osoby, to w przypadku normy pierwotnej rodzi się pytanie: kim ma być ta ,inna osoba” nakładająca akt przymusu? Normy prawne są aktem woli państwa, ale to również państwo nakłada akt przymusu. Można by ewentualnie tłumaczyć, że chodzi o inne organy państwa, konkretnych ludzi, ale to chyba przypominałoby sytuację, w której twierdziłoby się, że prawa i lewa ręka określonego człowieka to dwie różne podmiotowości.

Weinberger dodaje, że również rozpatrując obowiązywanie norm na podstawie kryteriów formalnych, dochodzi się do osobliwych rezultatów. Jeśli zatem uzna się, że sens aktu tworzenia na mocy definicji jest normą prawną, to wola

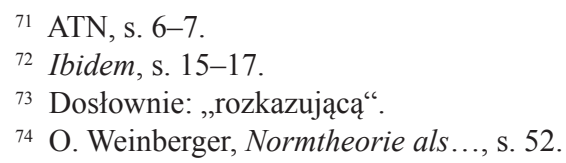


jest skierowana na państwo i jego organy. Oznacza to, że w razie niewypełnienia woli państwa przez organ (państwo) musi być zastosowany przez państwo przymus wobec organu (państwa). Weinberger konkluduje, że normy, które zawierają dozwolenie lub upoważnienie w kombinacji z teorią sankcji, tworzą absurdalne połączenie ${ }^{75}$.

W przypadku upoważnienia Weinberger zwraca uwagę na znacznie większą jego rolę w stosunku do wcześniejszych publikacji ${ }^{76}$. Kelsen wyróżnia dwa rodzaje upoważnień: nakazujące, które wiąże się z obowiązkiem określonego działania organu, oraz niezobowiązujące (dozwalające). W konsekwencji upoważnienie posiada również dwie funkcje. Po pierwsze, może tylko upoważniać odpowiedni organ do wydania normy. Po drugie, czasem upoważnienie do wydania normy jest jednocześnie związaniem normą podmiotów podlegających jej. Kelsen podaje przykład, w którym pierwsza norma brzmi: „ojciec może dawać polecenia swojemu dziecku”, a druga: „dziecko musi się podporządkować poleceniom ojca"77. Te funkcje, jak wskazuje Weinberger, sprawiają, że upoważnienie jawi się jako połączenie dwóch norm, z których jedna określa pozycję upoważnienia, a druga wskazuje na powód obowiązywania prawa. Oznacza to, że upoważnienie zostaje zredukowane do „specyficznej struktury związków między możnością a powinnością" 78 . Istnieje zatem szczególne połączenie pomiędzy zawartością aktu woli pierwszej normy i normatywną zawartością drugiej ${ }^{79}$. Normy upoważniające, nie zawierające w sobie elementu przymusu, na przykład, normy konstytucyjne są postrzegane przez Kelsena jako warunek obowiązywania normy zawierającej sankcję. Wskazane są przy tym dwie funkcje, które taka norma spełnia. Po pierwsze, skierowana jest do organu, który zostaje upoważniony do wydania normy prawnej określonej treści; po drugie, tym samym jest warunkiem obowiązywania wydanej normy ${ }^{80}$. G. Kucsko-Stadlmayer zrekonstruowała formułę takiej normy ${ }^{81}$ :

Kiedy

na podstawie prawa konstytucyjnego organ do tego umocowany przewidzianym przez prawo konstytucyjne postępowaniu wyda normę zawierająca element przymusu

i

ma miejsce stan faktyczny, z którym ta norma łączy sankcję

To

według prawa procesowego, które normuje postępowanie, umocowany do tego organ powinien zastosować tę sankcję.

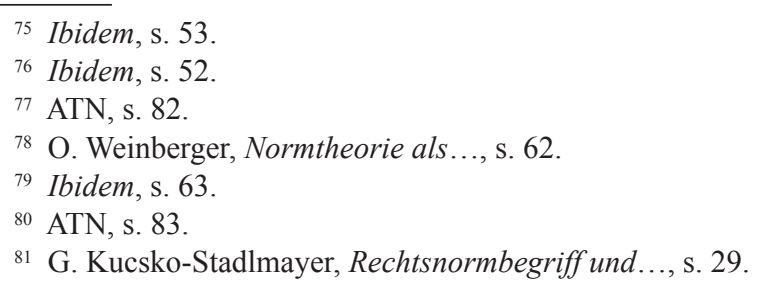


Weinberger krytykuje Kelsena za takie ujęcie, twierdząc, że norma upoważniająca jest ważna bez względu na to, czy na końcu tego łańcucha norm zaistnieje akt przymusu, czy nie. Ma ona samodzielny charakter ${ }^{82}$. Rodzi to pewne implikacje dotyczące zarachowania, które zostaną omówione dalej. Natomiast, jak twierdzi Weinberger, w myśl Kelsenowskiej koncepcji leges imperfecta nie są normami prawnymi, ponieważ obowiązek ich spełnienia ma charakter moralny ${ }^{83}$.

Dozwolenie, nie zawierające w sobie ani nakazu, ani zakazu, Kelsen podzielił na dwa rodzaje: dozwolenie w sensie negatywnym i dozwolenie w sensie pozytywnym. Dozwolenie w sensie negatywnym polega na braku ujęcia przez ustawodawcę określonego stanu rzeczy jako nakazanego lub dozwolonego. Jest to zatem fakt prawnie indyferentny. Weinberger zwraca uwagę, że jest to tzw. bilateralne dozwolenie. Polega ono na ustaleniu, że zachowanie $Z$ jest dozwolone, gdy Z nie jest przedmiotem nakazu ani zakazu, czyli ani zachowanie $Z$, ani zachowanie nie-Z nie jest przedmiotem nakazu ${ }^{84}$.

Natomiast norma dozwalająca $\mathrm{w}$ sensie pozytywnym ma tak naprawdę charakter derogujący, ograniczając stosowanie określonego nakazu lub zakazu (np. obrona konieczna może ograniczać zakaz zabójstwa) ${ }^{85}$. W tym sensie warunkuje ona istnienie innej normy o charakterze nakazującym i również ma charakter bilateralnego dozwolenia ${ }^{86}$. W odniesieniu do tego przypadku można zapytać, jaki jest zatem status norm derogujących, które, jak podkreślał Kelsen, polegają na zniesieniu obowiązywania jednej normy za pomocą innej. Taka norma nie stanowi powinności, tylko nie-powinność (Nicht Sollen) określonego działania lub zaniechania, które w normie derogowanej było powinnością (derogacja formalna). Norma derogująca może w takim wypadku obowiązywać wyłącznie w związku z obowiązywaniem normy derogowanej ${ }^{87}$. Norma może być również derogowana wtedy, gdy jedna z norm przestaje obowiązywać ze względu na kolizję norm (derogacja materialna). W pierwszym przypadku norma derogująca obowiązuje tylko, o ile norma derogowana przestanie obowiązywać ${ }^{88}$. Oznacza to, że wszelkie normy czy to prawa materialnego, czy zawarte w konstytucji, czy też o charakterze proceduralnym, nie są normami pełnymi, a jedynie warunkami, jakie muszą zostać spełnione, aby możliwe było nałożenie sankcji na konkretną osobę. Na powyższym przykładzie wyraźnie widać, że w owej normie występuje głównie upoważnienie, nie zaś nakaz. Mamy do czynienia tylko z normami

${ }^{82}$ O. Weinberger, Reine Rechtslehre zwischen Kritizismus und analytischer Philosophie, „Zeitschrift für Öffentliches Recht“ 2000, H. 55, s. 381.

${ }^{83}$ Ibidem, s. 379.

${ }^{84}$ O. Weinberger, Normtheorie als..., s. 57.

${ }^{85}$ ATN, s. 78-79; por. G. Kucsko-Stadlmayer, Rechtsnormbegriff und..., s. 32; takie ujęcie aprobuje Weinberger (O. Weinberger, Normtheorie als..., s. 57).

${ }^{86}$ O. Weinberger, Normtheorie als..., s. 57.

${ }^{87}$ ATN, s. 85.

${ }^{88}$ Ibidem, s. 86; G. Kucsko-Stadlmayer, Rechtsnormbegriff und..., s. 33. 
proceduralnymi, a nie z typową normą skierowaną do obywatela. Normy materialne są niejako wtórne i jeśli nawet pojedynczy przepis sankcji nie posiada (bo na przykład jest przepisem kompetencyjnym), to już w połączeniu z innymi stworzy normę, która sankcję posiadać będzie ${ }^{89}$. Fritzche zauważył w tym kontekście, że chodzi tu o „redukcję upoważnienia stanowienia prawa do upoważnienia urzeczywistniania prawa" $"$.

\subsubsection{Norma prawna a zdanie prawne}

Kelsen w ostatniej fazie wprawdzie nie zrezygnował z podziału na normę prawną i zdanie prawne, jednak ze względu na nowe akcenty, które pojawiły się w definicji normy prawnej, warto sprawdzić, czy ów podział nie uległ modyfikacjom. Problem ten Kelsen porusza w rozdziale zatytułowanym Wypowiedź dotycząca normy: podwójne znaczenie powinności. Już sam tytuł skłania do postawienia pytania: dlaczego Kelsen zrezygnował z wcześniejszej terminologii: „zdanie prawne"? Wydaje się, że wynika to z tego, że bada on wszystkie normy, nie tylko prawne. Sformułowanie „zdanie prawne” ma sens, ale jedynie w odniesieniu do norm prawnych.

Tym razem dla Kelsena punktem wyjścia jest podział na powinność preskryptywną i deskryptywną. Pierwszy rodzaj odnosi się do imperatywów, natomiast drugi do zdań opisujących rozkazy ${ }^{91}$. Widać tu wyraźnie, jak bardzo przesunął się punkt ciężkości. W dwóch poprzednich fazach wątki dotyczące poznania miały centralny charakter. Kelsen pytał, jak możliwe jest poznanie prawne i udzielał na to pytanie odpowiedzi - albo odwołując się do neokantyzmu, albo dokonując podziału na zdania prawne i normy prawne. Teraz ten wątek został usunięty nieco w cień. Jeśli nawet Kelsen pisze o wypowiedziach na temat norm, to raczej ma się wrażenie, że chodzi o rozróżnienie na płaszczyźnie językowej, a nie epistemologicznej. Kelsen stwierdza na przykład, że:

Takie zdanie powinnościowe, które [...] jest wypowiedzią o obowiązywaniu normy jest sensem aktu myślowego i jest - jak każda wypowiedź - w odróżnieniu od zdania powinnościowego, które jest normą i jako takie jest sensem aktu woli, prawdziwe lub fałszywe ${ }^{92}$.

Norma i wypowiedź na temat normy, tak jak w poprzedniej fazie, przybierają tę samą formę (na przykład: ,jeśli ktoś dokonał kradzieży, powinien zostać ukarany karą więzienia"). Zatem wydaje się, że tym razem można postawić tezę, że owa różnica odnosi się do pragmatyki. Kelsen wskazuje, że wśród wypowiedzi

89 S.L. Paulson, An Empowerment Theory of Legal Norm, „Ratio Juris” 1988, no. 1, s. 67.

${ }_{90}$ T. Fritzsche, Die Reine Rechtslehre im Lichte des Kritischen Rationalismus, Schriftenreihe des Hans Kelsen-Instituts, Wien 2002, s. 38.

${ }^{91}$ ATN, s. 122.

92 Ibidem. 
o normach należy odróżnić wypowiedzi dotyczące normy, a konkretnie jej obowiązywania od wypowiedzi na temat aktu, którego sensem jest norma (akt stanowienia prawa). Te drugie są wypowiedziami o istnieniu w rzeczywistości pewnych aktów ${ }^{93}$. Podczas gdy sam akt należy do sfery bytu, to norma do powinności. Kelsen podkreśla, że o ile na opisanie samego aktu, którego sensem jest norma prawna, stosuje się wyrażenie „normodawstwo”, a rezultatem jest „norma”, to w przypadku wypowiedzi o normie takiego rozróżnienia brak. Zarówno wypowiedź dotycząca norm, jak i normodawstwa funkcjonuje pod jednym pojęciem - opisu ${ }^{94}$. Jak wskazuje Kelsen:

wypowiedź, której sensem jest akt myślowy, jest znaczeniem zdania, które z kolei jest produktem aktów mowy, w których sens aktu zostaje wyartykułowany ${ }^{95}$.

Zatem między normą a wypowiedzią o niej można wyróżnić następujące różnice: po pierwsze, znaczenia zdania, które albo jest sensem aktu woli, albo sensem aktu myślowego; po drugie, norma ma funkcję normatywną, podczas gdy wypowiedź opisową; po trzecie, wypowiedź może być prawdziwa lub fałszywa, a norma nie; po czwarte, funkcją wypowiedzi jest wiedza, podczas gdy w przypadku norm takiej analogii przeprowadzić nie można, ponieważ nie jest możliwe uznanie, że tą funkcją jest wola ${ }^{96}$. Jak wskazuje Kelsen, między aktem wolitywnym a aktem myślowym istnieje jednak połączenie. Każdy akt woli jest poprzedzany przez akt myślowy, ponieważ jeśli ktoś czegoś chce, aby było przedmiotem normy prawnej, to musi najpierw o tym pomyśleć, ale nie w kontekście bytu, tylko powinności. To, co zostaje pomyślane, to substrat modalnie indyferentny ${ }^{97}$.

Weinberger podejmuje krytykę tej koncepcji, podnosząc, że takie ujęcie problemu oznacza odrzucenie obiektywizacji sensu aktów woli. Wyrażony w mowie sens aktu woli jest obiektem komunikacji o charakterze intersubiektywnym ${ }^{98}$. Z tego punktu widzenia Weinberger przedstawia m.in. następujące uwagi. Po pierwsze, zarówno myśli o charakterze deskryptywnym, jak i preskryptywnym, mające udział w intersubiektywności, muszą być rozumiane jako obiektywne, czyli jako znaczenie językowej wypowiedzi. Po drugie, komunikacja funkcjonuje tylko wtedy, gdy na początku i na końcu kanału komunikacyjnego powstaje ten sam obraz myśli. W przypadku Kelsena, który twierdzi, że jeśli A wypowiada normę, to $\mathrm{B}$ jest jej przedmiotem, a $\mathrm{C}$ otrzymuje wypowiedź na temat normy, ten warunek nie został spełniony. Po trzecie, norma jest obiektem, który poznaje się w zupełnie inny sposób aniżeli obiekty o charakterze

${ }_{93}$ Ibidem, s. 123.

94 Ibidem, s. 124.

95 Ibidem, s. 131.

96 Ibidem.

97 Ibidem, s. 133-134.

${ }_{98}$ O. Weinberger, Normtheorie als..., s. 39. 
materialnym. Takie poznanie może mieć miejsce jedynie wtedy, gdy wypowiedzi na temat norm zostaną zrozumiane. Po czwarte, Kelsen zastępuje element rozumienia normatywnego komunikatu sądem o porządku prawnym (czyli zdaniem prawnym) i zdeterminowaniem, czy jest prawdziwy, czy nie. Jednak to może nastąpić, wskazuje Weinberger, tylko wtedy, gdy zrozumie się komunikat. Zatem wypowiedź o normach jest jedynie pseudowypowiedzią. Po piąte, wypowiedź na temat norm prawnych zawiera w sobie normatywny wątek mający swój wyraz w stwierdzeniu, że pod określonymi warunkami prawnymi, powinno nastąpić określone prawem następstwo. Weinberger nazywa to zdanie „warunkowym zdaniem powinnościowym" ${ }^{99}$. Zatem w wypowiedzi o normach prawnych musi zostać wyartykułowane, że zawartość danego porządku prawnego ma być rozumiana jako hipotetyczna norma. Weinberger konkluduje, że sensowność sądu dotyczącego porządku prawnego ugruntowana jest przez zrozumienie zawartych w nim zdań normatywnych i następnie poprzez ustalenie ich obowiązywania. Oznacza to, że o obowiązywaniu norm można mówić dopiero wtedy, gdy się je zrozumie $^{100}$. Weinberger podsumowuje:

Kelsenowskie przeciwstawienie normy prawnej i zdania prawnego ma swój rezultat w niezrozumieniu istoty komunikacji, w rezultacie czego powstaje obraz poznania prawa budzący spore wątpliwości ${ }^{101}$.

Szczególnie interesujące we wnioskach Weinbergera wydaje się jego wskazanie, że normatywność wypowiedzi o normach prawnych jest zawarta w zdaniu zawierającym warunek prawny i następstwo prawne. Wynikałoby zatem, że owa normatywność jest kreowana przez zarachowanie. Czy taka interpretacja jest możliwa na gruncie ATN - zostanie rozstrzygnięte poniżej.

Samo poznanie norm odbywa się za pomocą wypowiedzi na ich temat. Weinberger ściśle wiąże poznanie procesu komunikacyjnego z rozumieniem normatywnego sensu ${ }^{102}$. Poznanie norm jest jednak o wiele bardziej dynamicznym procesem: normy można nie tylko zrozumieć, ale również budować różne stwierdzenia na ich temat: o charakterze logicznym, dotyczące obowiązywania czy związków z innymi normami. Zatem, konkluduje Weinberger, istnieje wiele różnych sposobów, w jaki normy mogą być poznawane. Mają one jednak charakter pochodny, ponieważ zawsze podstawą poznania będzie zrozumienie, czyli zebranie ich deskryptywnej zawartości w całość ${ }^{103}$.

99 Ibidem, s. 44; O. Weinberger, War Kelsen Antipsychologist?, „Rechtstheorie“ 1995, Bd. 26, s. 566.

100 O. Weinberger, Normtheorie als..., s. 44.

101 O. Weinberger, Reine Rechtslehre..., s. 384.

102 O. Weinberger, Normtheorie als..., s. 80.

103 Ibidem, s. 81-82. 


\subsubsection{Normy i logika}

Wcześniej Kelsen twierdził, że istnieje możliwość zastosowania logiki do norm, zatem dwie normy sprzeczne nie mogą jednocześnie istnieć. W ATN Kelsen całkowicie odstąpił od tego poglądu, twierdząc, że zastosowanie logiki do norm jest niemożliwe. Stanowisko to Weinberger nazywa „,normatywnym irracjonalizmem" (Normenirrationalismus) ${ }^{104}$. Genezę tego zwrotu Heidemann upatruje już w roku 1940, kiedy Kelsen porzuca transcendentalną koncepcję norm na rzecz realistycznej i wprowadza podział na zdanie prawne i normę prawną. Doprowadziło to do osłabienia tezy o zastosowaniu logiki do norm. Nie da się jej już zastosować bezpośrednio, a tylko pośrednio przez zdania prawne ${ }^{105}$. Jak wskazuje Weinberger, punktem wyjścia, który doprowadził Kelsena do takiej konkluzji, jest podział aktów psychicznych na poznawcze (kognitywne) oraz wolitywne. Sensem i zarazem produktem tych pierwszych są sądy wyrażane w zdaniach, tych drugich - normy, wyrażane w zdaniach o normach ${ }^{106}$.

Kolejnym krokiem Kelsena jest twierdzenie, że poznania nie da się wywieść $\mathrm{z}$ woli i vice versa. Podczas gdy poznanie skierowane jest na prawdę, to w przypadku woli takiej analogii przeprowadzić się nie da. Wola jest subiektywna, ponieważ konstytuuje subiektywne akty i nie ma obiektywnego uzasadnienia, a co za tym idzie jest relatywna. Akty myślowe z kolei mają charakter kognitywny, myślenie jest jednym z rodzajów poznawania, a przy tym proces myślenia ujmowany jest przez Kelsena w kontekście logiki. Myślenie wiąże się z jednej strony ze strukturą myśli i ich wyrazem językowym, z drugiej z logicznymi operacjami. Owe operacje logiczne nie wiążą się z empirycznymi faktami, lecz ze strukturą i znaczeniem wyrażeń. Logika jest zatem możliwa tylko i wyłącznie na gruncie aktów kognitywnych. Normy nie posiadają w sobie czynnika obiektywizującego, który pozwoliłby na zastosowanie wobec nich logiki. Poza tym, jeśli norma jest ściśle powiązana z aktem woli z tego względu, że stanowi on warunek jej istnienia, to nie mogą istnieć normy będące logiczną konsekwencją innych norm ${ }^{107}$. Weinberger krytykuje twierdzenie Kelsena, że między obowiązywaniem normy generalnej i indywidualnej musi istnieć akt woli, ponieważ zawiera ono w sobie błąd petitio principii. Nic bowiem nie uzasadnia takiej tezy. Kelsen twierdzi jedynie, że norma jest rezultatem aktu woli i z tego wysnuwa wniosek, że akt woli jest konieczny dla istnienia normy ${ }^{108}$.

Kwestia zastosowania logiki do norm dotyczy, według Hartneya, dwóch zagadnień dotyczących sprzeczności i wynikania. Po pierwsze, czy dwie normy

104 Ibidem, s. 94.

105 C. Heidemann, Die Norm als..., s. 198.

106 O. Weinberger, Normtheorie als..., s. 21.

107 Ibidem, s. 21-26; O. Weinberger, War Kelsen..., s. 567; K. Opałek, Überlegungen..., s. 29-31; idem, Studia z teorii i filozofii prawa, Monografie Wydziału Prawa i Administracji Uniwersytetu Jagiellońskiego/A - Monografie, Kraków 1997, s. 85.

108 O. Weinberger, Normtheorie als..., s. 33. 
sprzeczne mogą współistnieć i po drugie, czy z norm generalnych wynikają normy indywidualne. Kelsen udziela na oba pytania odpowiedzi negatywnej. Sprzeczność między normami nie zachodzi, ponieważ normy nie są zdaniami w sensie logicznym. Natomiast normy indywidualne nie wynikają z norm generalnych, ponieważ logika dotyczy zdań, a nie obiektów, którymi są normy ${ }^{109}$, a z jednego aktu woli nie da się logicznie wywieść innego ${ }^{110}$. Tym samym Kelsen krytykuje koncepcję sylogizmu prawniczego. Według niego, przesłanki mają zupełnie inny charakter logiczny (pierwsza to norma, a druga to zdanie o fakcie) ${ }^{111}$.

Z kolei von Wright zauważa, że w przypadku zdań preskryptywnych istnieją duże kontrowersje. Jeśli bowiem zachodziłaby sprzeczność między normami, to oznaczałoby, że dwie normy nie mogłyby współegzystować, co jest niezgodne ze zdrowym rozsądkiem. Według niego, logiczna sprzeczność nie zachodzi między samymi normami, tylko między zawartością owych norm. Von Wright konkluduje, że logika deontyczna dotyczy stanów idealnych wyrażonych w normach prawnych ${ }^{112}$.

Warto teraz skoncentrować się na konsekwencjach, przedstawionych przez Hartneya, które wynikają z tezy o niezastosowalności logiki do norm.

Po pierwsze, zmiana dotyczy zdań prawnych Wcześniej zawierały one zdanie orzekające o istnieniu określonej normy, zatem można było do nich zastosować reguły logiki. Obecnie według Kelsena jest to niemożliwe. Hartney twierdzi, że w tej sytuacji Kelsen albo musi porzucić twierdzenie, że zdanie prawne stwierdza istnienie obowiązującej normy, albo stwierdzić, że nie da się zastosować logiki do zdań prawnych ${ }^{113}$. Za drugim rozwiązaniem opowiada się Paulson, wskazując, że chodzi tu o zdania "norma x obowiązuje" i „norma y obowiązuje” i nie są one ze sobą sprzeczne ${ }^{114}$.

Po drugie, jeśli dwie normy są ze sobą niezgodne, to nie wyklucza to ich współistnienia. Oznacza to, że Kelsen musi porzucić pozytywistyczną tezę o możliwości istnienia tylko jednego porządku normatywnego. Zatem ta teza determinuje relacje między prawem krajowym a międzynarodowym oraz dopuszcza obowiązywanie - obok porządku prawnego - innego porządku normatywnego,

${ }^{109}$ M. Hartney Introduction..., s. XLIII; warto zauważyć jednak, Kelsen dopuszcza, że na mocy wyrażeń zawartych w normach, sylogizm, w którym mamy do czynienia z dwoma normami generalnymi, gdzie jedna z nich jest uszczegółowieniem drugiej. W takiej sytuacji jednak nie powstaje żadna nowa norma, norma generalna bowiem z wniosku zawarta jest już w normie generalnej z przesłanki. Kelsen wskazuje, że o ile normę generalną zawartą we wniosku ustawodawca przewidział, o tyle normy indywidualnej, że Kowalski ma zapłacić 156789876 zł Nowakowi, przewidzieć nie mógł (ATN, s. 201-202).

110 C. Heidemann, Die Norm als..., s. 205.

111 Ibidem.

112 G.H. von Wright, Is and Ought, [w:] S.L. Paulson, B. Litschewski-Paulson (eds), Normativity and Norms, Clarendon Press, Oxford 1998, s. 373-375.

113 M. Hartney, Introduction..., s. XLIX.

114 S.L. Paulson, Kelsen's Legal..., s. 273. 
na przykład prawno-naturalnego ${ }^{115}$. Ponadto, zmiana ta, jak wskazuje Hartney, ma ważne konsekwencje dla relacji między prawem krajowym a międzynarodowym.

Po trzecie, powstaje pytanie, w jaki sposób możliwe jest wydanie decyzji indywidualno-konkretnej. Według Kelsena kluczowy jest tutaj akt woli. Na jego podstawie powstają poszczególne normy ${ }^{116}$. Mimo wszystko, wydaje się, że trudno jest wyjaśnić obowiązywanie normy indywidualnej, nie odwołując się do jakiś logicznych powiązań z normą generalną ${ }^{117}$. Kelsen wprawdzie wyjaśnia, że o ile między normami nie ma logicznych powiązań, to występują one na poziomie pojęć, nazw użytych w normach. Hartney jednak zauważa, że Kelsen popełnia tu błąd petitio principii, szukając uzasadnienia dla obowiązywania norm i jednocześnie wychodząc z założenia, że dwie normy już obowiązują. Przy czym Kelsen nie ma wyjścia i musi założyć, że obie normy już obowiązują, żeby uniknąć odwołania do kategorii logicznych, iż z normy generalnej wynika norma indywidualna ${ }^{118}$.

Po czwarte, według Hartneya, ujęcie norm generalnych jako norm nadających kompetencję zupełnie pomija specyfikę systemów statycznych opartych na treści, a nie na kompetencjach ${ }^{119}$. Jednak, jak wskazuje Opałek, dynamiczny system w czystej postaci zawierałby wyłącznie normy kompetencyjne i nic więcej, zatem system prawa musi być systemem mieszanym. Według Opałka, Kelsen nie do końca był tego świadom, ponieważ system mieszany rozpatruje jako rodzaj systemu, który jest możliwy poza systemem dynamicznym ${ }^{120}$.

Według Heidemanna, rezultatem odrzucenia tezy o zastosowaniu logiki do norm jest jednoczesne odrzucenie możliwości dokonania analogii między prawdziwością lub fałszywością zdań a obowiązywaniem lub nieobowiązywaniem norm. Heidemann wskazuje na dwa argumenty za tym przemawiające. Po pierwsze, mamy tu do czynienia z inną kategorią: obowiązywanie jest „egzystencją", podczas gdy prawdziwość lub fałszywość jest cechą. Po drugie, prawdziwość zdania nie jest uzależniona od aktu myślowego, a obowiązywanie jak najbardziej. Zdaniem Heidemanna, jednak oba argumenty nie wydają się przekonujące. Odnośnie do pierwszego argumentu istnieją wątpliwości dotyczące jednoznaczności relacji między istnieniem a cechą; zaś drugi argument osłabia niejasność definicji normy prawnej jako sensu aktu woli (od którego zależy jej obowiązywanie) $)^{121}$.

${ }_{115}$ RR2, s. 359; M. Hartney, Introduction..., s. XLIX.

116 M. Hartney, Introduction..., s. XLIX; zob. R. Walter, Das Problem des normativen Syllogismus, [w:] W. Krawietz, J. Wróblewski (Hrsg.), Sprache Performanz und Ontologie des Rechts, Duncker Humblot, Berlin 1993, s. 348.

117 M. Hartney, Introduction..., s. LI.

118 Ibidem.

119 M. Hartney, Introduction ...; C. Heidemann, Die Norm als ..., s. 203-204.

${ }^{120}$ K. Opałek, Zum Problem des statischen und des dynamischen Normsystems, „Archiv für Rechts- und Sozialphilosophie“ 1993, Bd. 52, s. 85.

${ }^{121}$ C. Heidemann, Die Norm als..., s. 201. 
Jak zatem widać, odrzucenie logiki norm spowodowało nowe problemy na gruncie czystej teorii prawa. Kelsen jest jednak świadomy, że przedstawiona przez niego analogia jest nie do końca udana. Zauważa, że normy wyrażane są w zdaniach, które zawierają pewne wzajemne powiązania: między warunkiem i następstwem czy związki pojęciowe. W tym zakresie logika ma zastosowanie do norm, co zostanie bliżej wyjaśnione podczas analizy zarachowania ${ }^{122}$.

\subsection{Zarachowanie i przypisanie}

Podczas gdy pojęcie zarachowania wydaje się tracić na znaczeniu w ATN, to przypisanie praktycznie się tam nie pojawia. Kelsen wprawdzie poświęca zarachowaniu jeden rozdział, jednak to sformułowanie w dalszych częściach raczej nie jest używane. Wygląda to tak, jakby Kelsen go świadomie unikał, tym bardziej że są okazje, by je zastosować. Przykładem takiej sytuacji jest następujący cytat:

pozytywny porządek prawny nakazuje określone zachowanie, w którym zachowanie przeciwne wiąże z aktem przymusu jako sankcją, mówiąc dokładniej, w którym w przypadku takiego zachowania akt przymusu jest ustanowiony jako powinny, w tym sensie, że upoważnia do nałożenia aktu przymusu $^{123}$.

Wyraźnie Kelsen unika pojęcia zarachowania, zastępując je sformułowaniem „wiąże” (knüpft), które wcześniej znajdowało się w definicji zarachowania. Wydaje się to niezrozumiałe, skoro wcześniej zarachowaniu poświęcony jest rozdział, co wskazywałoby na to, że autor ATN nie miał intencji porzucenia tej konstrukcji. Rozwiązanie zagadki może być dość prozaiczne. Kelsen nie ukończył ATN. Pozostawił tylko notatki, które zostały opracowane przez jego następców. Być może jest to powód, dla którego o zarachowaniu trudno znaleźć więcej wypowiedzi.

Z powyższego cytatu wynika jednak coś jeszcze: Kelsen wprost pisze, że owa powinność nałożenia sankcji to tak naprawdę upoważnienie. Ta informacja przyda się podczas rozpatrywania zarachowania w kontekście poszczególnych funkcji norm prawnych.

\subsubsection{Definicja i charakter zarachowania}

Aby odpowiedzieć na pytanie, jak zarysowuje się pojęcie zarachowania w ostatniej fazie i jakie spełnia funkcje, warto na początku sprawdzić, czy coś się zmieniło w definicji zarachowania. Kelsen definiuje zarachowanie w następujący sposób:

122 ATN, s. 154; C. Heidemann, Die Norm als..., s. 203.

${ }^{123}$ ATN, s. 77. 
W stworzonym przez normy moralne albo prawne połączeniu między warunkiem i sankcją jako następstwem, które jest opisane przez etykę i naukę prawa [...] zaproponowałem nazwać je zarachowaniem $^{124}$.

Z kolei w artykule On Pure Theory of Law Kelsen definiuje zarachowanie jako: „ukonstytuowane za pomocą normy jako sensu aktu woli” 125 .

Widać zatem, że Kelsen dostosował pojęcie zarachowania peryferyjnego do nowej definicji normy. Zauważalna zmiana dotyczy też sankcji, która zastąpiła akt przymusu. Prawdopodobnie wynika to z tego, że Kelsen odnosi sankcję również do norm moralnych, podczas gdy przymus nie jest z pewnością ich elementem konstytutywnym. Poza tym definicja nie uległa zmianie.

Kelsen stwierdza również, że:

Ta normatywna konieczność, która wyraża się w połączeniu warunku i następstwa [...], która została wytworzona przez normy indywidualne, $[. .$.$] nakazujące zachowanie, to akt przymusu zwa-$ ny sankcją, jako następstwo stanu niezgodnego z prawem ${ }^{126}$.

Z powyższego cytatu ponownie wyłania się obraz zarachowania jako wytworzonego przez normę. Jednak w tej fazie nie jest to już problemem, skoro norma jest ujmowana jako spełniająca funkcję illokucyjną. Można zatem zaproponować interpretację, według której funkcja performatywna normy generalnej wyraża się m.in. w tym, że tworzy połączenie między warunkiem i następstwem w normie zawartym. Moim zdaniem, przy takiej interpretacji zarachowanie pojawiałoby się podczas procesu konkretyzacji normy prawnej. Wskazywałby na to również nacisk, jaki Kelsen położył w przytoczonym zdaniu na normy indywidualne. Czy zatem zarachowanie pojawia się jedynie w normach indywidualnych? Moim zdaniem, ta konstrukcja dotyczy obu rodzajów norm, nie ma bowiem powodu, by uznać, że łącznik występujący w normach generalnych jest czym innym aniżeli w normach indywidualnych.

Jak wskazuje Hartney, również w rozważaniach dotyczących przyczynowości i zarachowania doszło do zmian. Kelsen ostatecznie całkowicie porzucił kantowskie rozumienie przyczynowości jako kategorii a priori, czyli pewnego wyposażenia umysłu pozwalającego porządkować dany przez zmysły materiał. Teraz przyczynowość jest niezależna od człowieka, jest czymś wobec niego zewnętrznym. Naukowiec może ją tylko opisywać. Zarachowanie, mimo że zależne od człowieka jako rezultat aktu woli ${ }^{127}$ (ponieważ to ustawodawca decyduje, co zostanie zarachowane), jest niezależne od naukowca, który może określoną normę jedynie opisać ${ }^{128}$. Przyczynowość i zarachowanie zostały zdefiniowane jako

124 Ibidem, s. 19.

${ }^{125}$ H. Kelsen, On the Pure..., s. 3.

126 ATN, s. 18.

127 Ibidem, s. 20.

${ }_{128}$ M. Hartney, Introduction..., s. XXXIX. 
funkcjonalne, autonomiczne powiązania dwóch stanów. Są teraz przyczynową lub normatywną koniecznością, zatem w tej fazie zanikły wątpliwości, które pojawiły się u Kelsena wywołane przez Humowską teorię. Jak jednak skorelować pojęcie zarachowania z nowym stwierdzeniem, że powinność jako sens aktu woli jest normą? ${ }^{129}$ Czy to oznacza, że zarachowanie również jest normą? Wydaje się raczej, że Kelsen używa tu słowa „powinność” w dwóch znaczeniach: jedno z nich ma semantyczne konotacje: powinność rozumiana jest jako słowo „powinien" wyrażone w normie. Należy ją odróżnić od powinności, która jest normą.

Nowością jest stwierdzenie, że zarówno w zdaniach twierdzących i normach z punktu połączenie warunku i następstwa ma charakter logiczny ${ }^{130}$. Jest to istotny zwrot, jak bowiem zaznaczono, wcześniej Kelsen twierdził, że różnica pomiędzy normami a zdaniami twierdzącymi wyraża się właśnie $\mathrm{w}$ tym łączniku (w przyczynowości lub $\mathrm{w}$ zarachowaniu) ${ }^{131}$. Jak uzasadnia tę tezę, jednocześnie utrzymując twierdzenie, że niemożliwe jest zastosowanie logiki do norm? Kelsen stwierdza, że prawdziwość i fałszywość odnosi się do całych zdań, a nie do łącznika pomiędzy nimi. Powiązanie między warunkiem i następstwem w zdaniach powstaje dopiero wtedy, gdy zdanie jest prawdziwe. Z kolei w normach powiązanie to zależy o tego, czy norma obowiązuje. $Z$ tego względu, argumentuje Kelsen, nie ma znaczenia, czy owo powiązanie odnosi się do następstw w sferze bytu, czy w sferze powinności ${ }^{132}$. Mimo, że niemożliwa jest logika norm w zakresie ich wynikania i sprzeczności między nimi, to możliwe są inne reguły, na przykład subsumcja czy relacja aktu woli (którego sensem jest norma) do normy upoważniającej jego wydanie ${ }^{133}$. Co oznacza takie ujęcie dla konstrukcji zarachowania peryferyjnego? Przede wszystkim traci ono swój normatywny charakter. Normatywność wypowiedzi jest nadawana raczej poprzez akt woli, zaś zarachowanie to po prostu łącznik, który różni się od przyczynowości głównie tym, że nie ma charakteru koniecznego i tworzy powiązania skończone ${ }^{134}$. Z logicznego punktu widzenia ma jednak te same właściwości, a to rodzi kolejne wątpliwości, co to znaczy. Jednym z ryzykownych rozwiązań może być teza, że Kelsen ma na myśli spójnik implikacji.

Kolejna wątpliwość nasuwająca się przy takim ujęciu dotyczy pytania: czym jest powinność w relacji do zarachowania? Wydaje się, że na spójne wyjaśnienie tej relacji pozwala odwołanie się do postawionej wcześniej tezy, że jest to powinność na poziomie semantycznym, a jej rolą jest jedynie wyrażenie normatywnych

129 Zob. ATN, s. 21.

130 Ibidem, s. 216; M. Hartney, Introduction..., s. XIX.

131 Por. H. Kelsen, On the Pure..., s. 2; mimo że artykuł wyraźnie zalicza się do ostatniej fazy, to tu jeszcze zarachowanie występuje w swojej tradycyjnej funkcji, przeciwstawione przyczynowości.

132 ATN, s. 216.

133 Ibidem.

134 Ibidem, s. 2. 
powiązań w języku. Należy ją odróżnić od powinności, która jest sensem aktu woli i wydaje się być umiejscowiona na płaszczyźnie ontologicznej. To do niej odnosi się stwierdzenie, że bytu nie da się wywieść z powinności i vice versa. Dzięki takiemu ujęciu możliwe jest pogodzenie logicznego charakteru powiązań między warunkiem i następstwem w zdaniach i normach z tym, że jedne należą do bytu, a drugie do powinności. Wynikałoby z tego, że zarachowanie ma charakter wtórny. Jest jednym z rezultatów całego procesu, który bierze swój początek w akcie woli. Moim zdaniem takie rozwiązanie powoduje, że zanika różnica między zarachowaniem preskryptywnym w normie a deskryptywnym w wypowiedzi o normie. Żadne z nich nie ma teraz normatywnego charakteru. Warto zatem wrócić do pytania, co nadaje danemu aktowi mowy normatywny charakter.

Jak wskazuje Edward van Alphen, jest to interpretacja. By tak się stało, akt, który ma być aktem prawnym, najpierw w subiektywnym znaczeniu musi zostać sformułowany $\mathrm{w}$ relacji zarachowania (jeśli..., to wtedy powinno...). Bez tego zabiegu, akt jest bez znaczenia z punktu widzenia powinności. Drugim etapem jest transformacja znaczenia subiektywnego w znaczenie obiektywne. Zarachowanie jest zatem formalną regułą wskazującą, jaką postać ma przybrać dany akt, aby mógł być normą ${ }^{135}$. W tym kontekście odpowiadając na pytanie, czym jest zarachowanie, Jackson wskazuje, że jeśli spojrzy się na zarachowanie jako operację wyjaśniającą, dlaczego określona zaszłość, akt mowy nabiera normatywnego charakteru, to zarachowanie może zostać określone, jako „transformacja znaczenia" ${ }^{136}$. Van Alphen znakomicie opisał, na czym owa transformacja miałaby polegać":

Proces prawny, który kończy się sędziowską decyzją jest dobrym przykładem transformacji znaczenia prawnego [...]. Historie, zaprezentowane przez strony [...] w sądzie są poddane tej transformacji od samego początku. Obie historie są rekonstrukcją prawną faktu mającego miejsce wcześniej. Ten fakt, który spowodował wszczęcie procedury prawnej, nigdy tak naprawdę w sądzie nie został w pełni zrekonstruowany. Transformacja znaczenia dokonuje się aż do końca procesu prawnego. W rezultacie, jego wynik jest trudny do przewidzenia. Jednym z powodów jest złożoność procesu, ale innym, najważniejszym powodem jest to, że strony na każdym etapie procesu starają się wykreować prawną rzeczywistość, która najlepiej odpowiada im celom w (tej) bitwie prawnej. To powoduje, że proces transformacji odbywa się wciąż na nowo i również umiejscawia fakty coraz w to nowym kontekście (najpierw niemającym charakteru prawnego, potem prawnym, jako obrona lub atak w procesie etc. $)^{137}$.

Ten proces, według van Alphena, przebiega następująco: określony fakt zostaje opisany odpowiednio do danych reguł, przez co, na mocy tych reguł tworzona jest nowa rzeczywistość. Konsekwencją jest zmiana postrzegania tego

${ }^{135}$ E. van Alphen, Kelsen and Hruschka: Concepts of Imputation, „International Journal for the Semiotics of Law" 1993, vol. VI, no. 17, s. 169.

136 B.S. Jackson, Semiotics and Legal Theory, Routledge Kegan \& Paul, London 1987, s. 229-235.

137 E. van Alphen, Kelsen and..., s. 175. 
faktu, która sprawia, że tworzony jest nowy fakt już o innym efekcie. Następnie ma miejsce przejście do imputatio iuris, gdzie temu faktowi nadawane jest kolejne nowe znaczenie - znaczenie prawne ${ }^{138}$. Jak dalej wskazuje van Alphen, kelsenowską koncepcję można by zrekonstruować następująco: ,istnieje norma, która określa relacje pomiędzy faktem, a jego skutkiem prawnym”, co oznacza, że norma określa warunki, pod którymi dany fakt nabiera prawnego charakteru. Zarachowanie można zatem uznać za ową zasadę, na mocy której to, co należało do faktyczności teraz znajduje się w sferze powinności. To niezmiernie ciekawa i wartościowa interpretacja, znakomicie wpasowująca się na pierwszy rzut oka w analityczną koncepcję czystej teorii prawa. Jednak należy zadać pytanie, czy w sytuacji, w której Kelsen, jak się wydaje, pozbawił zarachowanie normatywnego charakteru, jest interpretacją słuszną. Czy zarachowanie może pełnić rolę reguły wskazującej warunki, jakim musi sprostać akt, by stał się normą prawną. Naturalnie nie chodzi tu o warunki formalne powstawania norm prawnych (gdzie warunkiem jest akt woli), lecz o płaszczyznę językową i wydaje się to możliwe na tej płaszczyźnie, jeśli przyjmie się, że jednocześnie nie jest tak, że to zarachowanie konstytuuje normę prawną. Zatem chodziłoby o sytuację, w której zarachowanie umożliwia rozpoznanie normy prawnej wśród innych aktów. Konstytutywny byłby akt woli, który owej formalnej regule zarachowania nadawałby w danym przypadku określoną treść.

\subsubsection{Zarachowanie a norma prawna}

Wątpliwości może również budzić relacja zarachowania do normy prawnej, zdefiniowanej na nowy sposób. Dotychczas nie ulegało wątpliwości, że norma była pewnym idealnym obiektem mającym swoją określoną, specyficzną budowę. W skład jej struktury wchodziło zarachowanie. Obecnie, sytuacja wygląda na o wiele bardziej skomplikowaną, ponieważ rodzi się pytanie: czym jest norma? Czy nadal można postrzegać ją jako idealny obiekt, czy może raczej jako pewne zjawisko językowe? A jeśli jest zjawiskiem językowym, to czy analizując jej strukturę, na gruncie języka, jest w niej miejsce dla zarachowania? Struktura normy w tej fazie zaproponowana przez Kelsena sprowadza się raczej do substratu modalnie indyferentnego, modalności oraz podmiotów. Hartney wskazuje, że strukturę normy prawnej można zilustrować za pomocą następującego schematu ${ }^{139}$ :

$$
c \rightarrow O x \text { albo } O(c \rightarrow x)
$$

gdzie $c$ oznacza warunek, $O$ - operator powinnościowy, $x$ - zachowanie.

\footnotetext{
138 Ibidem, s. 178.

139 M. Hartney, Introduction..., s. XIX.
} 
Zarachowanie jest łącznikiem pomiędzy zachowaniem podmiotu a sankcją. W normach pierwotnych, jeśli odmówić zarachowaniu jego normatywnego charakteru i przyjąć, że jest po prostu pewnym logicznym połączeniem warunku prawnego i następstwa, to wynika z tego, że zarachowanie jest zarazem elementem substratu modalnie indyferentnego. Warto jednak przy okazji podkreślić, że we wcześniejszych fazach konkluzja brzmiałaby odmiennie: zarachowanie umiejscowione byłoby poza substratem. Zarachowanie w substracie modalnie indyferentnym wtedy rodziłoby sprzeczność, było bowiem tym, co modalnie indyferentne nie jest. Wydaje się, że w przypadku zarachowania w kontekście zagadnień związanych z językiem, wciąż może ono funkcjonować jako element wskazujący, że wypowiedź ma charakter normatywny. Wtedy jednak pojawia się wątpliwość, czy nie wystarczy do tego odwołanie się do semantyki i słowa „powinien”. Dopóki norma istniała jako obiekt idealny, słowo ,powinien” było (i jest $\left.{ }^{140}\right)$ językowym przejawem zarachowania w niej zawartego. Jednak, gdyby norma była rozpatrywana jedynie na gruncie języka, to pozostałoby wyłącznie owo słowo „powinien”. Warto zatem zadać pytanie, czy na pewno w ATN wykluczona jest idealna egzystencja normy. Na to pytanie odpowiada Weinberger, stwierdzając że: „norma obowiązuje nie tylko jako sens aktu woli, ale również jako idea (Idealentität)" ${ }^{\prime 141}$. Idealna egzystencja normy wydaje się, według Weinbergera, wyrażać w tym, że norma będąca specyficznym rodzajem myśli, wyrażonej szczególnym rodzajem zdania jest możliwa do zrozumienia bez względu na to, czy odpowiedni akt mowy faktycznie miał miejsce ${ }^{142}$. Można zatem stwierdzić, że właśnie tu ma miejsce zarachowanie, a jego przejawem w akcie mowy jest słowo „powinien”. Na potwierdzenie tego, że Kelsen nie zrezygnował z koncepcji idealnej egzystencji normy prawnej, można przytoczyć następujące cytaty:

'Obowiązywać' w tym specyficznym, obiektywnym znaczeniu oznacza 'powinność przestrzegania'. To obowiązywanie normy jest jej specyficzną idealną egzystencją ${ }^{143}$.

Wypowiedź o normie, wypowiedź na temat bytu to wypowiedź dotycząca specyficznego bytu, bytu obecnego, specyficznej egzystencji normy, powinności, gdzie „bycie” powinności, egzystencja normy jest czym innym niż byt [...] to idealne, a nie realne bycie, idealne, nie realne istnienie ${ }^{144}$.

Jak wskazuje Opałek, ta idealność jest wytwarzana przez empiryczny, realny akt woli, zauważając, że jeśli na to spojrzeć z punktu widzenia dualizmu bytu i powinności, to widoczna jest tu niekonsekwencja ${ }^{145}$. Jednak dla zarachowania

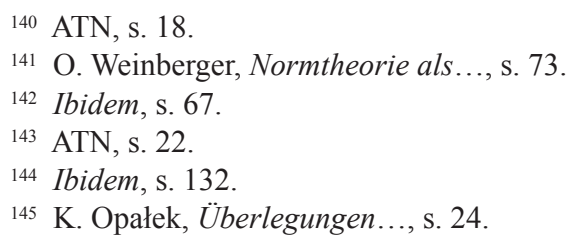


ta niekonsekwencja nie powinna mieć większego znaczenia. Na podstawie tych dwóch cytatów można stwierdzić, że Kelsen nie zrezygnował z koncepcji idealnej egzystencji normy prawnej. Zarachowanie peryferyjne ma zatem pod tym względem rację bytu, funkcjonując na pewnym planie idealnym, wyrażane w językowym aspekcie za pomocą powinności.

Podsumowując, zarachowanie to łącznik występujący w normie, nienadający jej jednak cechy normatywności. Dotyczy zarówno norm generalnych, jak i indywidualnych w ich ontologicznym wymiarze, podczas gdy na płaszczyźnie językowej wyrazem zarachowania jest powinność.

Pewne zamieszanie może również spowodować opisany wcześniej podział norm ze względu na ich funkcje. Wiadomo, że zarachowanie peryferyjne powinno się znajdować na końcu łańcucha norm o charakterze upoważniającym. Wiadomo również, jakie słabości taka konstrukcja za sobą niesie. Pojawia się pytanie: co z łańcuchem norm na końcu którego sankcji brak? Wydaje się, że gdy zarachowaniu odmówiono konstytutywnego charakteru, przestaje być to problemem. Naturalnie, sam problem dotyczący charakteru takiej normy pozostaje. Ewidentnie nowa definicja normy nie jest skorelowana $\mathrm{z}$ koncepcją, w której cechą konstytutywną normy jest przymus. Z kolei, jeśli wyeliminować przymus z katalogu koniecznych cech normy, to nowa koncepcja zarachowania znakomicie się wpasowuje w całość teorii.

\subsubsection{Zarachowanie a podmiot prawa}

W kontekście zmiany definicji osoby, która teraz dotyczy ludzi, a nie tworów prawnych, pojawia się pytanie: czy w tej konstrukcji zarachowanie peryferyjne ma rację bytu? Ja wiadomo, łączy ono warunek prawny z następstwem prawnym. Wydaje się, że nawet, jeśli wprowadzi się tu pojęcie osoby w psychologicznym tego słowa znaczeniu, to definicja zarachowania wprawdzie zmieni nieco sens, ale go nie straci. Po pierwsze, Kelsen nawet pisząc o ludziach podkreśla, że tak naprawdę chodzi o ludzkie zachowania ${ }^{146}$. Zarachowanie wciąż odnosi się albo do zachowań, albo do - posługując się terminologią Kelsena - innych warunków ${ }^{147}$, czyli zdarzeń. Tym samym zarachowanie nadal może być uwzględnione jako element normy prawnej, łączący ludzkie zachowanie niezgodne z dyspozycją normy prawnej z obowiązkiem nałożenia przez odpowiedni organ (w postaci konkretnej osoby) sankcji. Potwierdzeniem tego jest rozróżnienie na adresata bezpośredniego i pośredniego. Adresatem bezpośrednim hipotetycznej normy generalnej jest organ mający zastosować akt przymusu. Z kolei zachowania adresatów pośrednich stanowią warunek nałożenia takiej sankcji.

\footnotetext{
146 ATN, s. 23, 72-73.

147 Ibidem, s. 74.
} 
Kelsen w związku z tym wyróżnia dwa stadia stosowania prawa w tym zakresie. Po pierwsze, ustalenie, że w konkretnym przypadku zostały spełnione przesłanki zawarte w normie generalnej. Rezultatem tego jest wydanie normy indywidualnej skierowanej do organu wykonawczego i zawierającej powinność wykonania aktu przymusu. Stadium drugie to wykonanie aktu przymusu zgodnie $\mathrm{z}$ normą ${ }^{148}$. Zarachowanie ma miejsce w fazie pierwszej. Jest ,wytworzone” przez normę generalną. Czy znajduje się jednak w normie indywidualnej? Jeśli ma ona charakter imperatywu, to na pierwszy rzut oka nie może, ale jeśli, że przyjmie się, że i ona ma warunkową postać - pod warunkiem, że norma ta obowiązuje, to odpowiedź powinna być raczej twierdząca. Wówczas bowiem, jak wskazuje Kelsen, zachowanie będące warunkiem zastosowania aktu przymusu jest pośrednim warunkiem obowiązywania normy indywidualnej ${ }^{149}$. Natomiast zarachowanie z pewnością występuje $\mathrm{w}$ normie indywidualnej o hipotetycznym charakterze, która mogłaby przybrać na przykład następującą postać: ,jeśli pozwany $\mathrm{X}$ nie zapłaci powodowi Y $400 \mathrm{zł} \mathrm{w}$ ciągu 14 dni od uprawomocnienia się wyroku, to powinna zostać wobec niego zasądzona egzekucja" ${ }^{150}$.

Skoro Kelsen łączy pojęcie osoby z zachowaniem, to warto zadać pytanie, czy zmieniła się definicja tego pojęcia. Vernengo wskazuje, że ludzkie zachowanie, na które skierowana jest norma, to coś empirycznie weryfikowalnego. Takie elementy, jak sposób zachowania, podmiot, czas i miejsce są dla Kelsena zakresem obowiązywania normy i są zdefiniowane jako elementy jej zawartości. Vernengo zadaje w tym kontekście pytanie, czy wszystkie podpadają pod powinność i wskazuje, że podmiot, czas i miejsce mogą zostać skwantyfikowane, ale nie mogą być obiektem modalności, dodając, że dotyczy to norm o charakterze kategorycznym ${ }^{151}$. Z kolei Heidemann wskazuje na odwołanie się Kelsena do fenomenologii Edmunda Husserla, gdy wspomina o aktach intencjonalnych. Akt woli jest aktem psychicznym, wewnętrznym, wymagającym introspekcji. Niekiedy byt w ujęciu psychologicznym, według Kelsena, nie podlega światu przyczynowości, jest odrębną wewnętrzną rzeczywistością bez żadnych przyczynowych związków z rzeczywistością empiryczną, innym razem do tej rzeczywistości należy ${ }^{152}$. W zależności od punktu widzenia, albo można rozpatrywać ludzkie zachowanie jako to, na co intencjonalnie skierowane są normy, albo jako zawartość określonej normy. Jeśli postrzega się normy jako reguły ludzkich zachowań, to nie rozpatruje się ich z punktu widzenia powinności, tylko raczej z punktu widzenia ich efektywności. Jeśli natomiast rozpatruje się ludzkie zachowania jako zawartość normy, to inaczej są one definiowane - jako znaczenie zdania powinnościowego ${ }^{153}$.

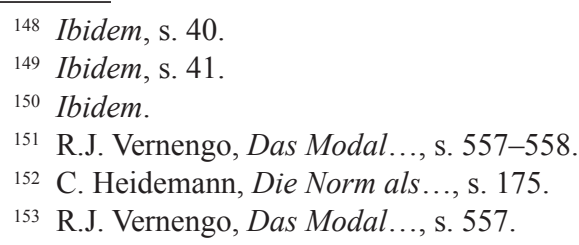




\subsubsection{Przypisanie}

Większy problem może się pojawić w przypadku przypisania, które albo wyobrażało linię łączącą poszczególne punkty zarachowania, albo odwołując się do późniejszych definicji tego pojęcia, polegało na zarachowaniu odpowiedniej osobie określonego zachowania. Teraz, gdy owa osoba nie jest już sztuczną konstrukcją prawną, tylko realną osobą, pojęcie zarachowania centralnego niczym się nie różni od zarachowania klasycznego i tak ujmuje to Kelsen w artykule Logisches und metaphysisches Rechtsverständnis. Jako przykład sytuacji, w której pojawia się zarachowanie centralne, Kelsen wskazuje na stwierdzenie sądu: „Mayer popełnił przestępstwo kradzieży", wyjaśniając, że w ten sposób kradzież została przypisana Mayerowi ${ }^{154}$. Jednak już w ATN pojęcie przypisania nie pojawia się. Wydaje się, że ten problem można wyjaśnić tym, że z jednej strony Kelsen poświęcił wiele uwagi upoważnieniu, które (jak to zostało wykazane w poprzednim rozdziale) jest swego rodzaju odpowiednikiem zarachowania centralnego. Można $\mathrm{z}$ tego wysnuć wniosek, że w ten sposób, w tym zakresie, Kelsen zrezygnował z przypisania. $Z$ drugiej, jak zauważa Jabloner, wcześniej Kelsen w celu obiektywizacji nauki prawa, w miejsce woli - szczególnie woli w znaczeniu psychologicznym - wprowadził zarachowanie centralne jako końcowy punkt zarachowania ${ }^{155}$.

Van Eikema Hommes zwraca uwagę na tę ważną zmianę: wola, o której Kelsen wspomina przy okazji definiowania normy prawnej, jest wolą w znaczeniu psychologicznym. I taką postać woli w znaczeniu psychologicznym Kelsen akceptuje jako faktyczne źródło norm prawnych. Zatem wola zaliczająca się do sfery bytu nabywa nową funkcję - źródła znaczenia norm prawnych. Jednak tego typu wola może odnosić się jedynie do powinności w subiektywnym znaczeniu. Powinność w znaczeniu obiektywnym powstaje dopiero wówczas, gdy źródłem woli jest podmiot wyposażony w odpowiednie kompetencje zawarte w normie wyższego rzędu ${ }^{156}$. Według van Eikema Hommesa, rezultatem takiego ujęcia jest utrata znaczenia przez przypisanie, które nabiera fikcyjnego charakteru i jest wyrazem relacji, łączącej działania indywiduów jako organów prawnych z jednością porządku prawnego ${ }^{157}$. Teraz, gdy wola jako akt psychiczny zajmuje w teorii Kelsena centralne miejsce, można uznać, że nie ma potrzeby utrzymywać obok konstrukcję przypisania ${ }^{158}$. Wydaje się zatem, że te wszystkie czynniki spowodowały zupełny zanik zarachowania centralnego, co nie powinno być szczególnym zaskoczeniem, biorąc pod uwagę, że Kelsen już w RR2 konsekwentnie powtarzał, że przypisanie to fikcja o charakterze pomocniczym dla zrozumienia pewnych konstrukcji.

${ }^{154}$ H. Kelsen, Logischen und Metaphysisches Rechtsverständnis, „Österreiches Zeitschrift für Öffentliches Recht und Völkerrecht" 1968, vol. 18, s. 10.

155 C. Jabloner, Kein Imperativ..., s. 84.

${ }^{156}$ H.J van Eikema Hommes, The Development..., s. 167.

157 Ibidem, s. 168.

158 C. Jabloner, Kein Imperativ..., s. 95. 


\subsection{Podsumowanie}

Ogólna teoria norm jest pozycją dość popularną jako przedmiot krytycznych uwag. Wielu autorów, jak na przykład Heidemann, zarzuca Kelsenowi, że porzucił bogatą intelektualnie neokantowską koncepcję czystej teorii prawa na rzecz tej, o wiele uboższej. Nie wydaje się jednak, by były to do końca trafne zarzuty. Według Opałka, na szczególne uznanie zasługuje fakt, że Kelsen niezwykle trafnie zidentyfikował podstawowe problemy dalszego potencjalnego rozwoju teorii prawa ${ }^{159}$. Kelsen miał znakomitą intuicję $\mathrm{w}$ identyfikowaniu nowych kierunków, które miały być dopiero rozwinięte w przyszłości. Jego książka została poprzedzona wnikliwymi badaniami zarówno z zakresu filozofii analitycznej, jak i nowych pionierskich publikacji podejmujących problem języka i logiki w nauce prawa. Śledząc jego wypowiedzi w RR2, można przewidzieć, jaki kierunek obierze w swoich dalszych nieustannych poszukiwaniach najdoskonalszej formy swojej teorii. Już tam widać, że Kelsen stoi nad Rubikonem i przygotowuje się do jego przekroczenia, ale jeszcze go nie przekracza. Ten proces następuje stopniowo, nowe elementy są wprowadzane $\mathrm{w}$ jego kolejnych artykułach, a stare nie tyle porzucane, co zanikają.

Ostatecznie przełomem staje się list do Kluga i stwierdzenie, że nie da się zastosować logiki do norm. Kelsen przeformułowuje swoją teorię, ale nigdy jej nie kończy. Książkę na podstawie notatek piszą jego następcy. W tej nieukończonej pracy jest coś symbolicznego, coś, co łączy przeszłość czystej teorii prawa z przyszłością. Ta teoria nigdy nie została skończona. Kelsen wciąż ją pisał na nowo, przeformułowywał, poprawiał. Mimo ogromnego sukcesu, jaki odniósł, nigdy nie przestał być krytyczny wobec swego dzieła. Gdy zmarł, nie nadając swej teorii ostatecznego kształtu, to zadanie przejęli jego uczniowie. Jednak myliłby się ten, kto sądzi, że czysta teoria prawa zyskała swą ostateczną formę w roku 1979, w momencie wydania Ogólnej teorii norm. Czysta teoria prawa, w swojej ostatecznej postaci, to tekst, który oderwał się od swojego twórcy i żyje własnym życiem. Istnieje kelsenowski świat, w którym kolejne pokolenia poszukają idealnej formy czystej teorii prawa, dostosowując ją wciąż do nowych wyzwań i potrzeb współczesności. Czysta teoria prawa poprzez kolejne interpretacje zmienia się, a nieukończona, niedoskonała Ogólna teoria norm jest tego symbolem. To, co wydaje się w pierwszym momencie jej słabością, jest zarazem jej siłą, gdyż już od kilkudziesięciu lat pozwala na twórcze poszukiwania i produktywną dyskusję. To wszystko umożliwił kelsenowski zwrot ku żywotnej do dziś filozofii analitycznej. Nie można również przeoczyć niezwykłej intuicji Kelsena. Już w ATN, jak wykazał Weinberger, słychać echa przyszłych teorii, w których prawo ukazane jest jako pewien aspekt komunikacji. Jest to oczywiście związek konceptualny, nie historyczny.

${ }^{159}$ K. Opałek, Überlegungen..., s. 10. 
Kelsen jest raczej naukowcem aniżeli filozofem. Świadczy o tym, moim zdaniem, kierunek rozwoju jego koncepcji. Zagadnienia filozoficzne Kelsen traktuje raczej pobieżnie, są one dla niego narzędziem w poszukiwaniu metody pozwalającej na stworzenie rzetelnej nauki prawa. Ten wątek wybija się u Kelsena wyraźnie na plan pierwszy. Nawet, gdy czerpie on inspirację z neokantyzmu, to dzieje się to właśnie w tym aspekcie, w którym neokantyści usiłują unaukowić prawoznawstwo. Kelsen nie boi się również porzucić transcendentalizmu, z którym jest kojarzony, na rzecz filozofii analitycznej, gdy zauważa, że ten nie spełnił pokładanych w nim nadziei. Zatem, sam normatywizm, czy raczej czysta teoria prawa, to projekt, którego nadrzędnym celem jest ugruntowanie prawa jako nauki. Kelsen, podobnie jak przedstawiciele pozytywizmu logicznego na gruncie bytu, poszukuje metody, która ugruntowałaby status prawoznawstwa jako nauki. Swoje myśli ostatecznie kieruje w stronę języka, co jest, moim zdaniem, trafne. Jeśli czystą teorię prawa potraktuje się jako pewien projekt do realizacji, to jest to droga, która pozwoli uchronić go od powszechnego zarzutu, że jest to koncepcja martwa i przestarzała. Czy taka będzie, zależy tylko od następców Kelsena.

Samo zarachowanie peryferyjne, mimo że dość dobrze wpasowuje się w całą koncepcję, nie odgrywa już tak znaczącej roli jak wcześniej, szczególnie za czasów neokantyzmu. Wciąż jednak odgrywa rolę na tyle ważną, że nie powinno zostać pominięte i wyrzucone z katalogu problemów wartych przedyskutowania. Widoczne jest, że Kelsen nie zdążył do końca dopracować koncepcji zarachowania jako łącznika o identycznym z punktu widzenia logiki charakterze, jak przyczynowość. Potencjalnie rodzi to pole do wielu interpretacji. Przedstawiłam propozycję jednej z nich. 


\section{Zakończenie}

Badając pojęcie zarachowania $\mathrm{w}$ poszczególnych stadiach rozwoju teorii prawa Kelsena, znakomicie widać proces jej tworzenia i doskonalenia. W pracy habilitacyjnej Kelsen zdaje się kierować raczej intuicją. Zauważa, że pojęcie zarachowania może być mu bardzo przydatne, ale gubi się podczas doprecyzowania go. Widać, że nie był on ani konsekwentny w definiowaniu pojęcia zarachowania, ani też nie stworzył spójnej jego konstrukcji. Bardzo wyraźne jest w tym okresie, że Kelsen ma zarysowaną koncepcję swojej teorii, ale jej detale wciąż nie są dopracowane. Zarachowanie $\mathrm{z}$ tej fazy razi, w porównaniu $\mathrm{z}$ fazami późniejszymi, mętnością konstrukcji. Dopiero lektura dzieł Cohena zmienia ten stan rzeczy, Kelsen znajduje bowiem wyraźną inspirację w neokantyzmie i to, co wcześniej było jedynie słabo zarysowanym pomysłem, zyskuje klarowność. Tak naprawdę dopiero $\mathrm{w}$ fazie neokantowskiej pojęcie zarachowania peryferyjnego nabiera kształtów, krystalizuje się jego definicja. Neokantyzm pozwolił Kelsenowi na uporządkowanie swojej teorii i nadanie jej solidnych fundamentów. Przy tym bardzo wyraźnie akcentuje on wątki epistemologiczne, opierając się na tradycyjnej opozycji podmiotu i przedmiotu, charakterystycznej dla pozytywizmu pierwotnego ${ }^{1}$. W tym epistemologicznym aspekcie zarachowanie peryferyjne zapewnia najbardziej spójny obraz argumentu transcendentnego, natomiast jako operator powinnościowy znakomicie spełnia swoją rolę w tej swoistej ontologii norm zarysowanej przez Kelsena. Można oczywiście zadać pytanie, czy taka ontologia wskazująca na świat powinności nie ma charakteru metafizycznego. Na to pytanie należy odpowiedzieć następująco: nawet, jeśli taki charakter by miała, to jest to cena za wyeliminowanie metafizyki z innych miejsc teorii prawa, i osiągnięcie jej głównego celu - eliminację ideologii z teorii prawa oraz zapewnienie czystość pojęć.

Zwrot Kelsena od Kanta ku Humowi, który jest widoczny już od lat czterdziestych. XX w., jest świadectwem jego krytycznej postawy wobec własnego dzieła i świadomości, że neokantyzm nie spełnił pokładanych $\mathrm{w}$ nim nadziei. W trzeciej fazie widać, że Kelsen się waha, przymierza do dostosowania swojej teorii do nowych nurtów w filozofii, ale wciąż, jakby wręcz automatycznie,

${ }^{1}$ M. Zirk-Sadowski, Pozytywizm prawniczy a filozoficzna opozycja podmiotu i przedmiotu poznania, „Studia z Filozofii Prawa”, Wydawnictwo UJ, Kraków 2001, s. 82-83; autor słusznie uważa takie ujęcie za wadliwe, ze względu na marginalizację roli sędziego sprowadzającej się do odtwórczego stosowania przepisów prawa. 
powtarza to, co charakterystyczne dla neokantyzmu. Wielu autorów uznaje RR2 za jego najważniejszą publikację i z pewnością jest to książka, w której Kelsen rozwija wątki jedynie zarysowane w RR1. Brakuje jej jednak konsekwencji znanej z wcześniejszych publikacji. Wyczuwalne są w niej rysy i pęknięcia. To jednak książka zarazem najważniejsza i wskazująca na okres przejściowy w twórczości Kelsena. I być może jej ważność właśnie na tym polega: można ją interpretować zarówno patrząc wstecz, w duchu kantowskim, jak i wybiegając myślami w kelsenowską przyszłość, w duchu Humowskim. Moim zdaniem, obie interpretacje są uprawnione. Zarachowanie peryferyjne w fazie realistycznej nie utraciło swej roli jako operator powinnościowy, jednak wraz z zanikaniem wątków transcendentalnych i ono zanika $\mathrm{w}$ roli przesłanki argumentu transcendentalnego. Jego rola jako operatora utrzymuje się również $\mathrm{w}$ ostatniej fazie. Przedefiniowanie pojęć nie wpłynęło na przydatność zarachowania w objaśnianiu zjawiska prawa. Jest stałym elementem struktury i, moim zdaniem, elementem koniecznym przy założeniu dualizmu bytu i powinności. W tej specyficznej ontologii świata, którego opis nie jest łatwym zadaniem, wydaje się pojęciem wyjątkowo dobrze doprecyzowanym. Warto jednak zauważyć, że wiele zależy tu od przyjętego rozumienia przyczynowości. Kelsen niechętnie wdaje się tu w wyjaśnienia. Raczej można domniemywać, że w fazie drugiej i jeszcze trzeciej miał na myśli rozumienie kantowskie, natomiast w ostatnim okresie raczej bliższy był mu Hume. Może to stanowić trop, w jaki sposób interpretować pojęcie zarachowania, jednak całkowitej pewności, czy jest to poprawna interpretacja, mieć nie można. Nie wydaje mi się jednak, by intencją Kelsena było oparcie się na solidnej teorii związku przyczynowo-skutkowego, by doprecyzować pojęcie zarachowania. Zarachowanie jest mu potrzebne dla wyjaśnienia struktury, jaką posiadają normy. Opis ten jest klarowny i wikłanie się w filozoficzne rozważania, co do natury powiązań przyczynowo-skutkowych mogłoby jedynie ów obraz zaciemnić, szczególnie, że zgody w tym zakresie wśród filozofów nie ma.

Z pewnością filozof zajmujący się ontologią zwróciłby tu uwagę na spore uchybienie. Jednak nie wydaje mi się, by Kelsen występował tu w roli filozofa pragnącego uchwycić istotę rzeczy. Jego cel jest o wiele bardziej praktyczny: jest nim opis pewnej struktury, narysowanie jak najwierniejszej mapy świata prawnego i dostarczenie narzędzi pozwalających ową mapę odczytać i w razie czego zmodyfikować. Stąd też nawiązań Kelsena do filozofii raczej należy szukać w epistemologii, a nie ontologii. I faktycznie, o zarachowaniu w jego epistemologicznym wymiarze można znacznie więcej powiedzieć. Kelsen to raczej naukowiec, niż filozof. Czy jednak Kelsen osiągnął swój cel i stworzył teorię naukową? To oczywiście zależy od pojęcia nauki. Są tacy, którzy nie uznają filozofii za naukę. Wówczas Kelsen żadną miarą nie miał szans stworzyć nauki prawa. Jeśli jednak posłużymy się szerszym pojęciem nauki i uznamy, że jej głównymi kryteriami są ogólność, możliwość empirycznej weryfikacji i jednoznaczność, gdzie jednoznaczność polegałaby tu na tym, że relacje między pojęciami są ści- 
śle określone, to należy udzielić odpowiedzi twierdzącej. Niewątpliwie Kelsen dążył do stworzenia uniwersalnej teorii prawa, takiej, która będzie aktualna bez względu na miejsce i czas, czyli jest to teoria ogólna. Kelsen już od drugiej fazy operuje pojęciami w konsekwentny sposób, niekiedy nadając im nowe znaczenie i osadzając w kontekście innych pojęć i czyni to raczej z sukcesem, czyli jego teoria posiada cechę jednoznaczności. Natomiast, z pewnością nie spełnia ona warunku możliwości weryfikacji empirycznej, ale to wynika bezpośrednio z jej założeń. Chyba że, jak zauważa Jerzy Wróblewski, w zamian za to wystarczyłaby kompatybilność z konkretnym system prawa. Moim zdaniem, taka weryfikacja w przypadku prawoznawstwa jest to wystarczające. Inną kwestią natomiast jest pytanie, dotyczące sposobu badania prawa. Kelsen twierdził, że naukowość prawoznawstwa jest możliwa wyłącznie wtedy, gdy wyeliminujemy wszelkie elementy obce. Z kolei Wróblewski zaprezentował krańcowo odmienne podejście: dla nauki prawa niezbędne jest wielowymiarowe podejście: na przykład, logiczno-językowe, psychologiczne, socjologiczne. Przychylałabym się raczej do tezy Wróblewskiego, widząc naukę prawa w szerszej perspektywie, gdzie kelsenowska płaszczyzna logiczno-językowa jest jedną z wielu. Na niej jednak, moim zdaniem, Kelsen dobrze wywiązał się ze swojego zadania.

Interesujące, że definicja zarachowania peryferyjnego praktycznie nie zmienia się do końca, choć zmienia się samo zarachowanie. Osadzane w coraz to nowym kontekście raz pełni funkcję relatywnej kategorii a priori, by innym razem zostać zredukowane jedynie do łącznika warunku i następstwa wyrażonego w normie. W ten sposób zarachowanie przypomina papierek lakmusowy. Zmienia barwy w zależności od otaczających je pojęć i filozoficznych koncepcji. Jest to element stały, ale charakteryzujący się dużą elastycznością. Wydaje się być tym samym jednym z bardziej udanych elementów czystej teorii prawa. Czy zatem zarachowanie może być uznane za swoisty test periodyzacji i normatywizmu? Jaki byłby rezultat takiego testu? Kto ma rację? Paulson, czy Heidemann? Z pewnością, jeśli jako za test periodyzacji przyjmiemy zarachowanie, to mamy do czynienia z czterema odrębnymi fazami w twórczości Kelsena. Natomiast, warto zauważyć, że gdyby takim testem miała być norma podstawowa, to pewnie bardziej trafne wydawałoby się stanowisko Paulsona. Ja jednak, przypisując zarachowaniu doniosłą rolę w koncepcji Kelsena, zgodziłabym się, że jest to jeden z najważniejszych możliwych testów periodyzacji. Zarachowanie jest również świetnym testem normatywizmu, pod warunkiem, że co do kwestii stopnia, a nie jako odpowiedź na pytanie czy w ogóle mamy do czynienia z normatywizmem. Wydaje się, że chyba nawet nie można wykluczyć jakiejś słabej odmiany normatywizmu bez zarachowania, ale z zachowaniem innych elementów. Najlepszym tego dowodem jest to, że w niektórych współczesnych interpretacjach zarachowanie jest w ogóle pomijane. Zatem, zarachowanie z pewnością może posłużyć jako jedno z kryteriów, ale chyba nie może być jedynym.

Samo zarachowanie peryferyjne wprawdzie w czwartej fazie straciło swą rolę, ale wciąż funkcjonuje w teorii Kelsena. Wydaje się więc, że ostatnią fazę można 
nazwać słabym normatywizmem. Kelsen nadal nie potrafi się rozstać z koncepcją normy podstawowej czy dualizmem bytu i powinności na płaszczyźnie ontologicznej. Natomiast, na pytanie, w jakim kierunku jego teoria by zmierzała, gdyby zdążył swoją książę ukończyć, to można zaryzykować przypuszczenie, że w kierunku porzucenia programu normatywizmu na rzecz teorii opisującej język prawa.

Nieco inaczej jest $\mathrm{z}$ zarachowaniem centralnym. Początkowo wysunięte na pierwszy plan, $\mathrm{z}$ biegiem czasu traci na znaczeniu, ostatecznie stając się konstrukcją całkowicie zbędną. O ile w HP Kelsen wydaje mu się nadawać nadrzędną rolę, o tyle w późniejszych publikacjach zaczyna sprawiać wrażenie zbędnego reliktu, który mógłby zostać zastąpiony przez koncepcję dynamicznej struktury prawa, tym bardziej, że relacje między zarachowaniem peryferyjnym a centralnym nie są do końca. Wbrew intencji Kelsena w wielu wątkach zamiast pomagać w zrozumieniu jego teorii, raczej to utrudnia. W przeciwieństwie do zarachowania peryferyjnego nie można tej konstrukcji uznać za udaną. Ostatecznie zarachowanie centralne zanika w ostatniej fazie zastąpione przez pojęcie upoważnienia i położenie w definicji prawa nacisku na wolę.

Reasumując, o ile można stwierdzić, że zarachowanie centralne jest konstrukcją raczej zbędną, o tyle zarachowanie peryferyjne znakomicie wpasowuje się w teorię Kelsena.

Czy jednak zarachowanie peryferyjne może być wykorzystane i dziś? Moim zdaniem, jeśli uznać czystą teorię prawa za jedną z najbardziej konsekwentnych prób opisu prawa $\mathrm{w}$ kategoriach wypracowanych przez pozytywizm, to zarachowanie peryferyjne do tego opisu jest niezbędne, choć mogą zachodzić wątpliwości, co do doniosłości roli, jaką pełni. Niewątpliwie może być pomocne w wyjaśnianiu specyfiki norm prawnych. Zarachowanie pozwala zarazem na szybkie odróżnienie norm od zdań odnoszących się do bytu, wskazanie na charakter powiązań między poprzednikiem a następnikiem, że nie zachodzi tam konieczność jak i na wskazanie jednej z istotnych cech prawa, jaką jest przymus. Tym samym wyjaśniając samo pojęcie zarachowania bardzo wiele można powiedzieć o specyfice norm prawnych i prawa.

W kontekście zarachowania można również zauważyć, że tradycyjny pozytywizm poszukiwał definicji prawa, która czyniłaby zadość wymogom klasycznej definicji Arystotelesa. Nie trudno było im znaleźć genus proximus, którym była norma. Problemy pojawiały się wraz z poszukiwaniem differentia specifica. Próbowano definicję prawa oprzeć na koncepcji państwa czy przymusu, jednak zawsze okazywało się, że takie definicję są albo niepełne, albo zawierają błąd błędnego koła (na przykład, prawo jako normy usankcjonowane przez państwo i państwo definiowane poprzez prawo). W tym kontekście można zadać pytanie, czy zarachowanie nie jest ową differentia specifica poszukiwaną przez poprzedników Kelsena. Czym byłoby prawo według takiej koncepcji? Byłoby zespołem norm zawierających w sobie zarachowanie peryferyjne. Definicja ta nabiera sensu dopiero w kontekście czystej teorii prawa. Bez niego jest zupełnie niejasna. Zatem 
odnosi się do niej większość zarzutów, jakie można sformułować pod adresem kelsenowskiego normatywizmu. Jednak moim zdaniem, ta definicja ukazuje jeszcze coś ważnego dla samej teorii Kelsena. Według mnie, jeśli poszukiwano by zdania oddających istotę czystej teorii prawa, to wskazana przeze mnie definicja by się do tego nadawała. Jeśli moja teza jest słuszna, to zarachowanie jest nie tylko jednym z elementów konstytuujących czystą teorię prawa, ale i pojęciem centralnym, oddającym istotę normatywizmu Hansa Kelsena. Zatem pytanie o rolę zarachowania nie może zostać postawione w oderwaniu od innego pytania, czy dziś jednak czysta teoria prawa może być przydatna? Sama analiza teorii Kelsena w jej poszczególnych fazach może doprowadzić do wniosku, że teoria ta zatoczyła koło. Kelsen w HP zwalczał to, co w ATN stało się kluczem do czystej teorii prawa: koncepcję rozkazu i wątki psychologiczne w nauce prawa. Czy zatem Kelsen krytykuje sam siebie? Nie, ponieważ nie mamy tu do czynienia z kołem, tylko spiralą. Pozornie wydaje się, że jest się w tym samym punkcie, co na początku, podczas gdy w rzeczywistości, to inne miejsce, na innym, wyższym poziomie. Krytyka ATN z pozycji HP jest niemożliwa z dwóch powodów: po pierwsze, ponieważ Kelsenowi nie można odmówić świadomości istnienia problemów metodologicznych; po drugie, ponieważ jego teoria, w przeciwieństwie do koncepcji poprzedników posiada silny fundament w postaci filozofii analitycznej. Wydaje się zatem, że na pytanie o aktualność kelsenowskiej teorii należy odpowiedzieć następująco: kelsenowski normatywizm zawiera bardzo porządny opis struktury prawa, którą niektórzy porównują do mapy. Dzięki temu można spojrzeć na całość porządku prawnego z „lotu ptaka”. Czy takie spojrzenie ma jakąś wartość?

Według mnie stanowi punkt wyjścia dla dalszych rozważań na temat prawa, w różnych aspektach przy zastosowaniu różnych metod. Zatem, to, czego nie da się utrzymać w kelsenowskiej teorii, to jej roszczenie do wyłączności. Ten element nie tylko nie znajduje uzasadnienia w samej teorii (co unaocznił argument transcendentalny) ale i może być szkodliwy, gdyby zamknąć się na inne teorie. Stanowisko to natrafia oczywiście na trudności. Jak na przykład zauważają Golecki i Wojciechowski: „współczesna teoria prawa odchodzi od monistycznej teorii systemu prawa Hansa Kelsena i uznaje bezpaństwowy charakter prawa". Ów bezpaństwowy charakter prawa to koncepcja, w której kilka systemów może istnieć obok siebie. Z jednej strony na tym, że część kompetencji tradycyjnie należących do państwa jest przeniesiona na pozapaństwowe podmioty. Przyczynia się to tworzenia i rozwoju ponadpaństwowego dyskursu prawniczego ${ }^{3}$. Wydawać by się mogło, że ta wizja jest zupełnie przeciwstawna wobec tego, czego orędownikiem był Kelsen. Jednak przywodząc na myśl ostatnią fazę nie można oprzeć się wrażeniu, że został tam przygotowany grunt dla tego typu koncepcji.

${ }^{2}$ M.J. Golecki, B. Wojciechowski, The Application of Law within a Multicentric Legal System, [w:] M. Zirk-Sadowski, M.J. Golecki, B. Wojciechowski (eds), Multicentrism as an Emerging Paradigm in Legal Theory, Dia-logos Peter Lang, New York 2009.

${ }^{3}$ Ibidem, s. 174. 
W tym sensie, krytykowana teza o niemożliwości zastosowania logiki do norm wydaje się trafna, ponieważ dzięki temu Kelsen może zrezygnować z twierdzenia, że dwa systemy prawa nie mogą istnieć jednocześnie i dopuścić w swojej teorii możliwość takiego pluralizmu. Oczywiście nie wszystkie elementy kelsenowskiej teorii da się tak wpasować. Na przykład koncepcja hierarchicznej struktury prawa jest nie do pogodzenia $\mathrm{z}$ wizją prawa, w której interakcje powstają na różnych szczeblach bez uwzględnienia hierarchicznego porządku ${ }^{4}$. Wydaje się zatem, że wskazane podobieństwa to za mało, by można było mówić w tym kontekście o aktualności kelsenowskiej koncepcji. Czy jest ona zatem reliktem? Teorią kiedyś modną, teraz jednak skazaną na zapomnienie? Przemawiałby za tym poważny zarzut formułowany pod adresem koncepcji pozytywistycznych, który można znaleźć w wielu pracach odwołujących się do zagadnień praktycznych związanych z prawem. Na przykład Stelmach i Brożek w Sztuce negocjacji prawniczych zauważają, że:

Pozytywizm prawniczy, choć historycznie jego zasług nie sposób podważać jest dzisiaj przestarzałą koncepcją prawa. Jego tezy nie są wystarczająco elastyczne, by sprostać dynamice procesu stosowania prawa [...] Inaczej mówiąc, pozytywizm jest ,wielkim hamulcowym 5 .

Nie sposób odmówić słuszności temu poglądowi, faktycznie polska kultura prawna została zdominowana przez jedną wizję prawa, szeroko rozumianego pozytywizmu. Jednym $z$ rezultatów tego faktu jest niedocenianie przez prawników miękkich sposobów rozwiązywania sporów, jak na przykład mediacja, czy negocjacje. Moim zdaniem, jednak koncepcja Kelsena nie musi zostać sprowadzona do roli muzealnego eksponatu. W uzasadnieniu takiej odpowiedzi przydatnym może się okazać właśnie odwołanie do istoty zarachowania. Prześledzenie ewolucji, którą przeszło pojęcie zarachowania prowokuje do postawienia zasadniczego pytania o ogólne wnioski i znaczenie tej konstrukcji w czystej teorii prawa. Czy można znaleźć jakiś wspólny mianownik, w sytuacji, w której zmieniało się zarówno pojęcie zarachowania, jak i kontekst, w którym się znajdowało? Czy można udzielić w miarę zadowalającej odpowiedzi o istotę zarachowania? Wydaje się, że tak. Od samego początku Kelsen posługiwał się wyrażeniami obrazującymi strukturę. Zarachowanie (zarówno peryferyjne, jak i centralne) to „linia łącząca” albo „połączenie”, „łącznik”. Łączy ono punkty. Owa siatka pojęciowa przywodzi na myśl geometrię, gdzie istnieją proste o charakterze nieskończonym, z których za pomocą punktów można tworzyć odcinki. Geometria jest nauką o strukturze i wydaje się, że właśnie struktury Kelsen, świadomie bądź nie, poszukiwał, budując swoja teorię prawa. Poszukiwał jego pierwotnej struktury, którą można byłoby ująć aksjomatycznie, w taki sposób, w jaki ujmuje się geometrię. $Z$ tego punktu

${ }^{4}$ Ibidem.

5 J. Stelmach, B. Brożek, Sztuka negocjacji prawniczych, Lex a Wolters Kluwer business, Warszawa 2011, s. 27. 
widzenia zarachowanie odgrywa kluczową rolę w teorii. To linia łącząca poszczególne punkty a od tego, w jaki sposób prowadzi się linię, zależy kształt figury, którą się stworzy. Te same punkty mogą utworzyć kwadrat, albo, jeśli poprowadzi się linie po przekątnych, inną figurę. Zarachowanie w takim ujęciu determinuje strukturę prawa, sprawia, że rozproszone punkty nabierają sensu. Widać to bardzo wyraźnie przy rozróżnieniu rodzajów zarachowania. Zupełnie inny obraz prawa wyłania się, gdy na pierwszym planie znajduje się zarachowanie klasyczne, a inny, gdy peryferyjne, czy centralne. Zarachowanie zatem odgrywa istotną rolę w budowaniu spójnej, ogólnej pozytywistycznej wizji prawa. A ta może pełnić rolę fundamentu, niezbędnego do tego, by można było dalej prowadzić rozważania filozoficzne. Jak trafnie pisze Zajadło:

pozytywizm nie oznacza a priori postawy filozoficznej czy wręcz antyfilozoficznej. Pozytywizm jest absolutnie naturalnym, koniecznym i niezbędnym instrumentarium pracy prawnika, ale tylko do poziomu wniosków prima facie; za nimi rozpościera się nieograniczona przestrzeń trudnych przypadków, przy rozwiązywaniu których nie wystarcza już zwykły prawniczy warsztat czy nawet kantowski rozum teoretyczny i odpowiadająca mu teoria prawa - trzeba sięgnąć do rozumu praktycznego, a zatem i etyki prawa ${ }^{6}$.

Wielkość Kelsena między innymi polegała właśnie na tym, że z niezwykłą konsekwencją na gruncie metodologii poszukiwał tych pierwotnych założeń. To niezbędne podstawy, które pozwalają innym uczynić kolejny krok, mający za zadanie pomóc dogmatykom rozstrzygać hard cases 7 . Wynika z tego, że czysta teoria prawa może stanowić fundament, punkt wyjścia, który pozwala prowadzić refleksję nad prawem na coraz wyższych, wyrafinowanych poziomach. Sama czysta teoria prawa niewiele wniesie do praktyki prawniczej. Jeszcze raz podkreślmy, że rola czystej teorii prawa sprowadza się do czegoś innego. Do odsłonięcia najbardziej podstawowe struktury myślenia prawniczego. Interpretacja, praktyka, to coś na innym, bardziej szczegółowym poziomie. Teorie filozoficzne też nie oferują rozwiązania, w jaki sposób, na przykład, naprawić samochód. Dotyczą czegoś innego na wyższym poziomie ogólności. Uważam, ze zarówno czystą teorię prawa, jak i doktryny filozoficzne można porównać do fundamentów domu. Wprawdzie można postawić dom bez fundamentów, to jednak taki dom nie będzie trwały. Fundamenty nie są widoczne, ale niezbędne, by zbudować coś solidnego.

Pytanie o aktualność Kelsena może również dotyczyć kwestii, czego dziś można się dowiedzieć z czystej teorii prawa. Czy dziś uwrażliwia ona czytelników na jakiś problem? I tu można zaryzykować udzielenie odpowiedzi twierdzącej. Odpowiedź ta wiąże się z najczęściej krytykowaną w doktrynie tezą. Kelsen miał tylu zwolenników, ilu przeciwników. Jego koncepcje do dziś w literaturze

${ }^{6}$ J. Zajadło, Po co prawnikom filozofia prawa?, Oficyna a Wolters Kluwer business, Warszawa 2008, s. 15.

7 Zob. ibidem, s. 7-17. 
są przedmiotem zarówno przedmiotem aprobaty, jak i miażdżącej krytyki. Jak wskazałam, słabych punktów, dających szerokie pole do interesującej polemiki tej teorii jest wiele. Najczęściej jednak można się spotkać z krytyką jednego zdania i to wyciągniętego z kontekstu, że treść prawa może być dowolna. To zdanie słusznie jest krytykowane. Ono powinno być krytykowane. Jednak po pierwsze, nie należy zapominać, w jakim kontekście zostało wygłoszone (z punktu widzenia naukowca - normatywisty, nie na przykład etyka); po drugie, warto przytoczyć słuszne spostrzeżenie Sławomiry Wronkowskiej:

Hans Kelsen autor bezlitośnie krytykowanej tezy głoszącej, że treść prawa może być dowolna, zdaje się zakładać jakąś treść konstytucji demokratycznego państwa, taką choćby, że ogranicza ona władzą prawodawczą zarówno w procedurach, jak i przez wyrażone w niej prawa jednostki, w treści tworzonych przez nią norm ${ }^{8}$.

Krytykując zatem Kelsenowską tezę, nie należy zapominać, że postawił ją Kelsen teoretyk prawa. Oprócz tego był architektem sądownictwa konstytucyjnego i orędownikiem demokracji. Myśli Kelsena nie można zaliczyć się do nurtu nihilizmu prawniczego, negującego możliwość istnienia związku między prawem i moralnością, lecz, wraz z Hartem do redukcjonizmu9. Wydaje się zatem, że jeśli można w ogóle wyprowadzać dalsze konsekwencje dotyczące stwierdzenia, że prawo może mieć treść dowolną, to w kontekście całości poglądów Kelsena, jego niechęci do wszelkich ideologii, należałoby je raczej traktować jako swego rodzaju ostrzeżenie, wezwanie do bycia czujnym i krytycznym wobec zawartości prawa. To dlatego Kelsen był tak przeciwny ideologizacji nauki prawa, gdyż dzięki ideologii przemyconej na tak podstawowym poziomie, teorii prawa, zostaje niejako a priori zdeterminowana jego treść. Kelsen jako relatywista nie mógł się na to zgodzić. I dziś zresztą, w dobie poszukiwania kompromisu między państwem neutralnym światopoglądowo, a ochroną pewnych wartości Kelsen brzmi wyjątkowo aktualnie.

Najlepszym dowodem, że teza Kelsena dotycząca dowolności treści prawa jest prawdziwa, jeśli w ten sposób zinterpretować jego słowa, są słynne już unormowania unijne kwalifikujące marchewkę do kategorii owoców a ślimaka do kategorii ryb. Naturalnie trudno to uznać za poważny problem, jednak uwidacznia on fakt, że tworząc prawo można dowolnie żonglować pojęciami, bawić się sensem, nie tylko w sprawach błahych. Że istnieje przepaść między światem faktów a światem normatywnym. Ślimak w naszym świecie jest rybą w świecie powinności. A skoro coś może być zdefiniowane w dowolny sposób, wbrew faktom, to czyny szkodliwe społecznie mogą stać się pożądanymi, wolności obywatel-

${ }^{8}$ S. Wronkowska, Posłowie, [w:] H. Kelsen, Istota i rozwój sądownictwa konstytucyjnego, Wydawnictwo Trybunału Konstytucyjnego, Warszawa 2009, s. 87.

9 Zob. J. Zajadło, Przedmowa do wydania polskiego, [w:] G. Radbruch, Filozofia prawa, Wydawnictwo Naukowe PWN, Warszawa 2009, s. LV. 
skie uznane za zagrażające demokracji a bezprawie stać się prawem. Wydaje się, że teoretycznie, poprzez zmianę sensu kluczowych pojęć za pomocą aktu normatywnego można sobie wyobrazić sytuację, w której unormowania dotyczące praw człowieka stają się nieefektywne. Lektura dzieł Kelsena z pewnością na ten problem uwrażliwia i można to poczytać za jego wielką zasługę, nawet jeśli jest to interpretacja w pewnym stopniu oderwana od tekstu twórcy.

Podsumowując, dopiero mając na względzie wielowymiarowość postaci Kelsena, można wdać się w polemikę z postulatami czystej teorii prawa. Z pewnością nie jest to teoria wolna od wad. Większość z zarzutów jest zresztą doskonale znana. Jest to jednak teoria wartościowa, zarówno jako kamień milowy w rozwoju teorii i filozofii prawa, jak i współcześnie - nie tylko jako punkt wyjścia, siatka pojęciowa umożliwiająca dalszą dyskusję, ale i jako unaocznienie problemów, które może napotkać dzisiejsze prawo. Fakt, że nieomal czterdzieści lat po śmieci Kelsena teoria ta, postrzegana jako radykalny odłam pozytywizmu, wciąż inspiruje, nieustannie prowokuje do stawiania nowych pytań, podejmowania nowych wątków w dyskusji (co łatwo stwierdzić po ilości ukazujących się corocznie publikacji) jest najlepszym dowodem jej ogromnej wartości i potencjału, który ze sobą niesie. 



\section{Bibliografia}

Achterberg N., Autonome Determinante und modal indifferentes Substrat, „Rechtstheorie“ 1984, Bd. 5 Adomeit K., Der Begriff der Rechtsnorm, Schriftenreihe des Hans Kelsen-Instituts, Wien 1982

Alexy R., Hans Kelsens Begriff des relativen Apriori, [w:] R. Alexy, L.H. Meyer, S.L. Paulson, G. Sprenger (Hrsg.), Neukantianismus und Rechtsphilosophie, Nomos Verlagsgesellschaft, Baden-Baden 2002

Behme T., Samuel von Pufendorf Naturrecht und Staat, Vandenhoeck Ruprecht, Göttingen 1995

Bekrycht T., Wstep, [w:] A. Reinach, Aprioryczne podstawy prawa cywilnego, thum. T. Bekrycht, Aureus, Kraków 2009

Black M., The Gap Between Is and Should, „The Philosophical Review” 1964, vol. 73, no. 2

Bodenheimer E., Law as a Bridge Between Is and Ought, „Ratio Juris” 1988, no. 2

Borowski M., Die Lehre vom Stufenbau des Rechts nach Adolf Merkl, [w:] S.L. Paulson, M. Stolleis

(Hrsg.), Hans Kelsen Staatsrechtslehrer und Rechtstheoretiker des 20. Jahrhunderts, Grundlagen der Rechtswissenschaft, Mohr Siebeck, Tübingen 2005

De Bustamante y Montoro A.S., Kelsenism, [w:] P.L. Sayre (ed.), Interpretations of Mordern Legal Philosophies - Essays in Honor of Roscoe Pound, F.B. Rothman, New York 1947

Dias G.N., Rechtspositivismus und Rechtstheorie, Mohr Steinbeck, Tübingen 2005

Dore I.I. ,The Epistemological Foundations of Law, Carolina Academic Press, Durham 2007

Ebenstein W., The Pure Theory of Law: Demythologizing Legal Thought, „California Law Review” 1971, vol. 59

Frege G., Über Sinn und Bedeutung, http://sammelpunkt.philo.at:8080/419/1/24-1-94.TXT [4 VI 2010]

Fritzsche T., Die Reine Rechtslehre im Lichte des Kritischen Rationalismus, Schriftenreihe des Hans Kelsen-Instituts, Wien 2002

Golecki M.J., Wojciechowski B., The Application of Law within a Multicentric Legal System, [w:] M. Zirk-Sadowski, M.J. Golecki, B. Wojciechowski (eds), Multicentrism as an Emerging Paradigm in Legal Theory, Dia-logos Peter Lang, New York 2009

Hammer S., A Neo-Kantian Theory of Legal Knowledge in Kelsen's Pure Theory of Law?, [w:] S.L. Paulson, B. Litschewski-Paulson (eds), Normativity and Norms, Critical Perspective on Kelsenian Themes, Clarendon Press, Oxford 1998

Hart H.L.A., Kelsen Visited, „University of California Los Angeles Law Review” 1963, vol. 10

Hart H.L.A., Positivism and Separation of Law and Morals, „Harvard Law Review” 1958, vol. 71

Hart H.L.A., The Concept of Law, Clarendon Press, Oxford 1961

Hartney M., Introduction: The Final Form of the Pure Theory of Law, [w:] H. Kelsen, General Theory of Norms, trans. Michael Hartney, Clarendon Press, Oxford 1991

Heidemann C., Der Begriff der Zurechnung bei Hans Kelsen, [w:] S.L. Paulson, M. Stolleis (Hrsg.), Hans Kelsen Staatsrechtslehrer und Rechtstheoretiker des 20. Jahrhunderts, Mohr Siebeck, Tübingen 2005

Heidemann C., Die Norm als Tatsache. Zur Normentheorie Hans Kelsen, Nomos Verlagsgesellschaft, Baden-Baden 1997

Heidemann C., Geltung und Sollen: Einige (neu-)kantische Elemente der Reinen Rechtslehre Hans Kelsens, [w:] R. Alexy, L.H. Meyer, S.L. Paulson, G. Sprenger (Hrsg.), Neukantianismus und Rechtsphilosophie, Nomos Verlagsgesellschaft, Baden-Baden 2002 
Heidemann C., Hans Kelsens Theorie normativer Erkenntnis, [w:] A. Brockmöller, D. Buchwald, D.V.D. Pfordten, K. Tappe (Hrsg.), Ethische und Strukturelle Herausforderungen des Rechts, Franz Steiner Verlag, Stuttgart 1997

Heidemann C., Noch einmal: Stanley L. Paulson und Kelsens urteilstheoretischer Normbegriff, „Archiv für Rechts-und Sozialphilosophie“ 2007, Bd. 93

Heidemann C., Norms Facts and Judgments. A Reply to S.L. Paulson, „Oxford Journal of Legal Studies" 1999, vol. 19

Hendler R., Die Staatstheorie Hans Kelsens, Juristische Schulung, C.H. Beck, München 1972

Hruschka J., Die Zurechnungslehre Kelsens in Vergleich mit der Zurechnungslehre Kants, [w:] S.L Paulson, M. Stolleis (Hrsg.), Hans Kelsen Staatsrechtslehrer und Rechtstheoretiker des 20. Jahrhunderts, red. Grundlagen der Rechtswissenschaft, Mohr Siebeck, Tübingen 2005

Hruschka J., Strukturen den Zurechnung, Walter de Gruyter, Berlin, New York 1976

Hruschka J., Verhaltensregeln und Zurechnungsregeln, ,Rechtstheorie“ 1991, Bd. 22

Jabloner C., Beiträge zur einer Sozialgeschichte der Denkformen: Kelsen und die Einheitswissenschaft, [w:] C. Jabloner, F. Stadler (Hrsg.), Logische Empirismus und Reine Rechtslehre; Beziehungen zwischen dem Wiener Kreis und der Hans Kelsens-Schule, Veröffentlichungen des Instituts Wiener Kreis Springer, Wien, New York 2001

Jabloner C., Bemerkungen zu Kelsens Vergeltung und Kausalität, besonderes zur Naturdeutung der Primitiven, „Rechtstheorie“ 1982, Bd. 4

Jabloner C., Kein Imperativ ohne Imperator. Anmerkungen zu einer These Kelsens, Schriftenreihe des Hans Kelsen-Instituts, Wien 1988

Jackson S., Semiotics and Legal Theory, Routledge Kegan \& Paul, London 1987

Joerden J.C., Logik im Recht, Grundlagen und Anwendungsbeispiele, Springer Verlag, Berlin, Heidelberg 2005

Kant I., Metafizyka moralności, tłum. E. Nowak, Wydawnictwo Naukowe PWN, Warszawa 2007

Kelsen H., Allgemeine Staatslehre, Österreichische Staatsdrückerei, Wien, Nachdrück 1993

Kelsen H., Allgemeine Theorie der Normen, Manzsche Verlags- und Universitätsbuchhandlung, Wien 1979

Kelsen H., Causality and Accounting, [w:] H. Kelsen, Essays in Legal and Moral Philosophy; selected and with an introduction by Ota Weinberger, trans. Peter Heath, Dordrecht Reidel 1973

Kelsen H., Czysta teoria prawa (Metody i pojęcia zasadnicze), oprac. T. Przeorski, przedruk z gazety administracji policji państwowej, Warszawa 1934

Kelsen H., Die philosophischen Grundlagen der Naturrechtslehre und des Rechtspositivismus, [w:] H.R. Klecatsky, R. Marcic, H. Schambeck (Hrsg.), Die Wiener rechtstheoretische Schule, Franz Steiner Verlag, Stuttgart 2010

Kelsen H., Die Rechtswissenschaft als Norm - oder als Kulturwissenschaft, [w:] H. Klecatsky, R. Marcic, H. Schambeck (Hrsg.), Die Wiener rechtstheoretische Schule, Europa Verlag Wien Frankfurt Zürich, Universitätsverlag Anton Pustet, Salzburg, München 1968

Kelsen H., General Theory of Law and State, The Law Book Exchange Ltd. Union, New Jersey 1999

Kelsen H., Gott und Staat, „Logos. Internationale Zeitschrift für Philosophie der Kultur“ 1922, H. 3

Kelsen H., Grundriß einer allgemeinen Theorie des Staates, Wien 1926

Kelsen H., Hauptprobleme der Staatsrechtslehre, Scientia Aalen, 1960

Kelsen H., Kausalität und Zurechnung, „Österreiches Zeitschrift für Öffentliches Recht und Völkerrecht" 1954, Bd. VI, H. 2

Kelsen H., Logischen und Metaphysisches Rechtsverständnis, „Österreiches Zeitschrift für Öffentliches Recht und Völkerrecht" 1968, H. 18

Kelsen H., On the Pure Theory of Law, „Israel Law Review” 1966, no. 1

Kelsen H., Podstawowe zagadnienia nauki prawa państwowego (w rozwinięciu nauki o normie prawnej), thum. T. Przeorski, Wilno 1935-1936 
Kelsen H., Rechtswissenschaft oder Rechtstheologie?, „Österreiches Zeitschrift für Öffentliches Recht und Völkerrecht"1966, Bd. XVI, H. 3-4

Kelsen H., Rechtswissenschaft und Recht, Franz Deuticke, Wien, Leipzig 1922

Kelsen H., Reine Rechtslehre, 1934, przedruk: Mohr Siebeck, Tübingen 2008

Kelsen H., Reine Rechtslehre, Verlag Franz Deuticke, Wien 1960

Kelsen H., Science and Politics, „The American Political Science Review” 1951, vol. XLV

Kelsen H., The Communist Theory of Law, Fredrick A. Praeger Inc., New York 1955

Kelsen H., Vergeltung und Kausalität, Herman Böhlaus Nachf., Wien, Köln, Graz 1982

Kelsen H., Was ist die Reine Rechtslehre?, [w:] Demokratie und Rechtstaat, Polygraphischer Verlag A.G., Zürich 1953

Kletzer C., Reflections on Hans Kelsen's Positivism, http://www.kletzer.com/assets/pdf/master.pdf [16 VII 2010]

Klug U., Die Reine Rechtslehre von Hans Kelsen und die formallogische Rechtfertigung der Kritik an dem Pseudoschluss von Sein auf das Sollen, [w:] S. Engel (ed.), Law State and International Legal Order, Essays in Honor of Hans Kelsen, The University of Tennessee Press, Knoxville 1964

Knapp V., Logische und ontologische Aspekte von Sein und Sollen (Gibt es ein Sollen des Seins und ein Sein des Sollens?), [w:] Die Normative Rechtstheorie im Kontext der Rechtswissenschaft, Masarykova Univerzita v Brnie, Brno 1991

Kucsko-Stadlmayer G. Rechtsnormbegriff und Arten der Rechtnormen, Schriften des Hans Kelsen-Instituts, Wien 1992

Lande J., Studia z filozofii prawa, PWN, Warszawa 1959

Leser N., Die Reine Rechtslehre im Wiederstreit der philosophischen Ideen, Schriftenreihe des Hans Kelsen-Institutes, Wien 1982

Lippold R., Reine Rechtslehre und Strafrechtdoktrin, Springer Verlag, Wien, New York 1989

Lübbe W., Handeln, und Verursachen: Grenzen der Zurechnungsexpansion, [w:] W. Lübbe (Hrsg.), Kausalität und Zurechnung. Über Verantwortung in komplexen kulturellen Prozessen, Walter de Gruyter, Berlin, New York 1994

Luf G., On Transcendental Import of Kelsen's Basic Norm, [w:] S. L. Paulson, B. Litschewski Paulson (eds), Normativity and Norms, Critical Perspective on Kelsenian Themes, Clarendon Press, Oxford 1998

Martyniak C., Moc obowiazujaca prawa a teoria Kelsena, [w:] C. Martyniak, Dzieła, red. ks. R. Charzyński, M. Wójcik, Wydawnictwo KUL, Lublin 2006

Merkl A. Prolegomena einer Theorie der Rechtlichen Stufenbaues, [w:] H. Klecatsky, R. Marcić, H. Schambeck(Hrsg.), Die wiener rechtstheoretische Schule, Europa Verlag Wien Frankfurt Zürich, Universitätsverlag Anton Pustet, Salzburg, München 1968

Opałek K., Wróblewski J., Prawo: metodologia, filozofia, teoria prawa, PWN, Warszawa 1991

Opałek K., Studia z teorii i filozofii prawa, Monografie Wydziału Prawa i Administracji Uniwersytetu Jagiellońskiego/A - Monografie, Kraków 1997

Opałek K., Überlegungen zu Hans Kelsens „Allgemeine Theorie der Normen, Schriftenreihe des Hans Kelsen-Instituts, Wien 1980

Opałek K., Zum Problem des statischen und des dynamischen Normsystems, „Archiv für Rechtsund Sozialphilosophie" 1993, Bd. 52, H. 3

Paulson S.L., An Empowerment Theory of Legal Norm, „Ratio Juris” 1988, no. 1

Paulson S.L., Arriving at a Defensible Periodisation of Hans Kelsen's Legal Theory, „Oxford Journal of Legal Studies" 1999, vol. 19

Paulson S.L., Die Zurechnung als apriorische Kategorie in der Rechtslehre Hans Kelsens, [w:] M. Kaufmann, J. Renzikowski (Hrsg.), Zurechnung als Operationaliesierung von Verantwortung, Peter Lang, New York 2004 
Paulson S.L., Faktum, Wert Distinktion: Zwei-Welten Lehre und immanenter Sinn Hans Kelsen als Neukantianer, [w:] R. Alexy, L.H. Meyer, S.L. Paulson, G. Sprenger (Hrsg.), Neukantianismus und Rechtphilosophie, Nomos Verlag, Baden-Baden 2002

Paulson S.L., Four Phases in Hans Kelsen's Legal Theory? Reflections on Periodisation, „Oxford Journal of Legal Studies" 1998, vol. 18

Paulson S.L., Hans Kelsen's Earliest Legal Theory: Critical Constructivism, „Modern Law Review” 1996, vol. 59

Paulson, S.L., Kelsen in Marburg School: Reconstructive and Historical Perspectives, [w:] W. Krawietz, N. MacCormick, G.H von Wright (Hrsg.), Prespective Formality and Normative Rationality in Modern Legal Systems, Duncker Humblot, Berlin 1994

Paulson S.L., Kelsen's Legal Theory: the Final Round, „Oxford Journal of Legal Studies” 1992, vol. 12

Paulson S.L., Konstruktivismus, Methodendualismus und Zurechnung im Frühwerk Hans Kelsens, „Archiv des öffentlichen Rechts“ 1999, Bd. 124

Paulson S.L., Lässt sich die Reine Rechtslehre transzendental begründen?, „Rechtstheorie“ 1990, Bd. 21

Paulson S.L., On the Implication of Kelsen's Doctrine of Hierarchical Structure, „The Liverpool Law Review" 1996, vol. XVIII(1)

Paulson S.L., On the Kelsen-Kant Problematic, [w:] E.G. Valdèz, W. Krawietz, G.H. Von Wright, R. Zimmerling (eds), Normative Systems in Legal and Moral Theory, Duncker Humblot, Berlin 1997

Paulson S.L., On Transcendental Arguments, Their Recasting in Terms of Belief and the Ensuing Transformation of Kelsen's Pure Theory of Law, „Notre Dame Law Review” 2000, vol. 75

Paulson S.L., The Neokantian Dimension of Kelsen's Pure Theory of Law, Oxford Legal Studies, Oxford University Press, Oxford 1992

Paulson S.L., Toward a Periodisation of the Pure Theory of Law, [w:] L. Gianformaggio (ed.), Hans Kelsen's Legal Theory a Diachotonic Point of Vieweded, G. Giappichelli Editore 1990

Paulson S.L., Zwei radikale Objektivirungsprogramme in der Rechtslehre Hans Kelsens, [w:] S.L. Paulson, M. Stolleis (Hrsg.), Hans Kelsen Staatslehrer und Rechtstheoretiker des 20. Jahrhunderts, Mohr Siebeck, Tübingen 2005

Pohlmann R., Zurechnung und Kausalität, ,Rechtstheorie“ 1985, Bd. 5

Raz J., Autorytet prawa, thum. P. Maciejko, Dom Wydawniczy ABC, Warszawa 2000

Raz J., Explaining Normativity: on Rationality and the Justification of Reason, „Ratio” 1999, vol. 12 , no. 4

Reinach A., Aprioryczne podstawy prawa cywilnego, thum. T. Bekrycht, Aureus, Kraków 2009

Renzikowski J., Der Begriff der „Zurechnung” in der Reinen Rechtslehre Hans Kelsens, [w:] R. Alexy, L.H. Meyer, S.L. Paulson, G. Sprenger (Hrsg.), Neukantianismus und Rechtphilosophie, Nomos Verlagsgesellschaft, Baden-Baden 2002

Sandkühler H.J., „Natur“ des Rechts und Relativismus in Recht. Eine Studie zu Gustav Radbruch und Hans Kelsen im Kontext Neukantianismus, [w:] R. Alexy, L.M. Meyer, S.L. Paulson, G. Sprenger (Hrsg.), Neukantianismus und Rechtphilosophie, Nomos Verlagsgesellschaft, Baden-Baden 2002

Sarkowicz R., Stelmach J., Filozofia prawa XIX i XX wieku, Wydawnictwo UJ, Kraków 1999

Sarkowicz R., Stelmach J., Teoria prawa, Wydawnictwo UJ, Kraków 1998

Schreier F., Rechtsnorm und Rechtssatz, Schriftenreihe des Hans Kelsen-Instituts, Wien 1982

Schulz L., Kausalität und strafrechtliche Produkthaftung. Materiell- und prozeßrechtliche Aspekte, [w:] W. Lübbe (Hrsg.), Kausalität und Zurechnung. Über Verantwortung in komplexen kulturellen Prozessen, Walter de Gruyter, Berlin, New, York 1994

Searle J.R., Fact and Value, ,Is” and „,Ought”, and Reasons for Action, [w:] G.O. Mazur (ed.), Twenty-Five Year Commemoration to the life of Hans Kelsen, Semenko Foundation, New York 1999 
Searle J.R., How to Derive Ought from Is?, „The Philosophical Review” 1964, vol. 73, no. 1

Simmel G., Filozofia kultury; wybór esejów, thum. W. Kunicki, Eidos Wydawnictwo UJ, Kraków 2009 Stelmach J., Metody prawnicze, Zakamycze, Kraków 2004

Stelmach J., Norma podstawowa, „Studia z Filozofii Prawa”, Wydawnictwo UJ, Kraków 2001

Stelmach J., Brożek B., Sztuka negocjacji prawniczych, Lex a Wolters Kluwer business, Warszawa 2011

Sykuna S., Zajadło J., International Justice - Between State Sovereignty and Human Rights?, [w:] B. Wojciechowski, M. Zirk-Sadowski, M.J. Golecki (eds), Between Complexity of Law and Lack of Order, Wydawnictwo Adam Marszałek, Torun-Beijin 2009

Tappe K., Ethische und Strukturelle Herausforderungen des Rechts, Franz Steiner Verlag, Stuttgart 1997

Teubner G., Die unsichtbare „Copula“": Kausalitäatkrise und kollektive Zurechnung, [w:] W. Lübbe (Hrsg.), Kausalität und Zurechnung. Über Verantwortung in komplexen kulturellen Prozessen, Walter de Gruyter, Berlin, New York 1994

Van Alphen E., Kelsen and Hruschka: Concepts of Imputation, „International Journal for the Semiotics of Law" 1993, vol. VI, no. 17

Van Eikema Hommes H.J., The Development of Hans Kelsen's Concept of Legal Norm, Rechtstheorie, Duncker Humblot, Berlin 1984

Vernengo R.J., Das Modal Indifferente Substrat der Normen in der Allgemeine Theorie der Normen, Rechtstheorie, Duncker Humblot, Berlin 1984

Von Pufedorf S., Über die Pflicht des Menschen und des Bürgers nach dem Gesetz der Natur, Insel Verlag, Frankfurt am Main, Leipzig 1994

Von Wright G.H., Is and Ought, [w:] S.L. Paulson, B. Litschewski-Paulson, [w:] M. Sherberg, Normativity and Norms, Clarendon Press, Oxford 1998

Walter R., Das Problem des normativen Syllogismus, [w:] W. Krawietz, J. Wróblewski (Hrsg.), Sprache Performanz und Ontologie des Rechts, Duncker Humblot, Berlin 1993

Weinberger O., Normtheorie als Grundlage der Jurisprudenz und Ethik, Schriften zur Rechtstheorie, Duncker Humblot, Berlin 1981

Weinberger O., Reine Rechtslehre zwischen Kritizismus und analytischer Philosophie, „Zeitschrift für Öffentliches Recht" 2000, H. 55

Weinberger O., War Kelsen Antipsychologist?, „Rechtstheorie“ 1995, Bd. 26

Welzel H., Die Naturrechtslehre Samuel Pufendorfs, Walter de Gruyter \& Co., Berlin 1958

Wiederin E., Das Spätwerk Kelsens, Schriftenreihe des Hans Kelsen-Institutes, Wien 2009

Winkler G., Rechtstheorie und Erkenntnislehre, Springer Verlag, Wien, New York 1990

Wojciechowski B., Justifying Punishment In Multicultural Societies, [w:] B. Wojciechowski, M. Zirk-Sadowski, M.J. Golecki (eds), Between Complexity of Law and Lack of Order, Wydawnictwo Adam Marszałek, Toruń-Beijin 2009

Wronkowska S., Postowie, [w:] H. Kelsen, Istota i rozwój sądownictwa konstytucyjnego, Wydawnictwo Trybunału Konstytucyjnego, Warszawa 2009

Wróblewski J., Egologiczna teoria prawa przeciw czystej teorii prawa, „Państwo i Prawo” 1959, nr 8-9

Wróblewski J., Krytyka normatywistycznej teorii prawa i państwa Hansa Kelsena, PWN, Warszawa 1955

Wróblewsk J., The Is - Ought Dichotomy, „Revue Internationale de Philosophie” 1981, vol. 138

Wróblewski J., The Problem of the Meaning of the Legal Norm, „Österreiches Zeitschrift für Öffentliches Recht und Völkerrecht" 1964, Bd. XIV, H. 3-4

Zajadło J., Po co prawnikom filozofia prawa?, Oficyna a Wolters Kluwer business, Warszawa 2008

Zajadło J., Przedmowa do wydania polskiego, [w:] G. Radbruch, Filozofia prawa, Wydawnictwo Naukowe PWN, Warszawa 2009 
Zalewska M., Zapomniana monografia „Ogólna teoria norm” Hansa Kelsena, [w:] O. Nawrot, S. Sykuna, J. Zajadło (red.), Konwergencja czy dywergencja kultur i systemów prawnych?, Wydawnictwo C.H. Beck, Warszawa 2012

Ziembiński Z., Uzasadnienie twierdzeń ocen i norm w prawoznawstwie, PWN, Warszawa 1988

Zirk-Sadowski M., European Judicial Governance and Legal Philosophy, [w:] B. Wojciechowski, M. Zirk-Sadowski, M.J. Golecki (eds), Between Complexity of Law and Lack of Order, Wydawnictwo Adam Marszałek, Toruń-Beijin 2009

Zirk-Sadowski M., Norma prawna jako kategoria pragmatyczna, „Zeszyty Naukowe Uniwersytetu Łódzkiego" 1980, S. I, z. 55

Zirk-Sadowski M., Pozytywizm prawniczy a filozoficzna opozycja podmiotu i przedmiotu poznania, „Studia z Filozofii Prawa”, Wydawnictwo UJ, Kraków 2001

Zirk-Sadowski M., Prawo a uczestniczenie w kulturze, Wydawnictwo UŁ, Łódź 1998

Zirk-Sadowski M., Soft-Kelsenism versus Multicentrism, [w:] M. Zirk-Sadowski, M. Golecki, B. Wojciechowski (red.), Multicentrism as an Emerging Paradigm in Legal Theory, Dia-logos Peter Lang, New York 2009

Zirk-Sadowski M., Wprowadzenie do filozofii prawa, Zakamycze, Kraków 2000

http://oxforddictionaries.com/view/entry/m_en_gb0403640\#m_en_gb0403640.008 [22 VII 2010]. http://usjp.pwn.pl/haslo.php?id=1895274 [29 VII 2010].

http://usjp.pwn.pl/haslo.php?id=1869481 [29 VII 2010]. 
Druk i oprawa: Quick Druk 
